\title{
Stereocontrolled Total Synthesis of (-)-Kaitocephalin
}

\author{
Rishi G. Vaswani and A. Richard Chamberlin ${ }^{\dagger} *$ \\ Contribution from the Department of Chemistry ${ }^{\dagger}$ and the Department of Pharmaceutical \\ Sciences ${ }^{\S}$ University of California, Irvine, Irvine, California 92697-2025
}

\section{Supporting Information}

Contents

I. Experimental Procedures and Compound Characterization..........................S1

II. ${ }^{1} \mathrm{H}$ NMR and ${ }^{13} \mathrm{C}$ NMR Spectra for Compounds trans-6, 8-10, trans-11, anti-12, syn-12, 13, 14, 26-30, 31(a/b), 33, 35-38, (Z)-39, 40 (a/b), 41 (a/b), (Z)-Br-42, 46 (a/b), (Z)-47, $(E)-47,(Z)-B r-48,50,52,56,58,62(a / b), 65,67,1$ (as bis-TFA salt), 1 (as mono-

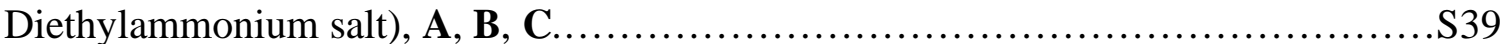

III. X-ray Crystallography data for Compounds 37, (Z)-39, 41b (CIF attached as separate

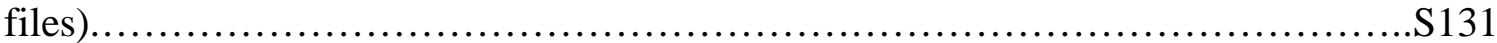

\section{Experimental Procedures and Compound Characterization}

General Experimental Methods. ${ }^{1} \mathrm{H}$ NMR spectra were either recorded at ambient temperature or elevated temperatures at 400, 500, and $600 \mathrm{MHz} .{ }^{13} \mathrm{C}$ NMR spectra were recorded at ambient temperature at 100, 125, and $150 \mathrm{MHz}$. For ${ }^{1} \mathrm{H} \mathrm{NMR}$ spectra acquired in $\mathrm{CDCl}_{3}$, chemical shifts are reported as $\delta$ values in ppm and are calibrated according to internal $\mathrm{CHCl}_{3}(7.26 \mathrm{ppm})$. For ${ }^{1} \mathrm{H}$ NMR spectra acquired in DMSO- $d_{6}$, chemical shifts are reported as $\delta$ values in ppm and are calibrated according to internal DMSO (2.50 ppm). For ${ }^{1} \mathrm{H}$ NMR spectra acquired in $\mathrm{D}_{2} \mathrm{O}$, chemical shifts are reported as $\delta$ values in ppm and are calibrated according to internal $\mathrm{H}_{2} \mathrm{O}$ (4.80 ppm). For ${ }^{13} \mathrm{C}$ NMR spectra, chemical shifts are reported as $\delta$ values in ppm relative to 
chloroform, acetonitrile and DMSO. For ${ }^{13} \mathrm{C}$ NMR spectra acquired in $\mathrm{D}_{2} \mathrm{O}$, chemical shifts are reported as uncalibrated $\delta$ values in ppm. The data are reported as follows: chemical shift in ppm on the $\delta$ scale, multiplicity $(\mathrm{app}=$ apparent, $\mathrm{br}=$ broad, $\mathrm{s}=$ singlet, $\mathrm{d}=$ doublet, $\mathrm{t}=$ triplet, $\mathrm{q}=$ quartet, quin $=$ quintet, $\mathrm{m}=$ multiplet, coupling constants $(\mathrm{Hz})$, and integration. Infrared spectra (IR) were obtained on an FTIR spectrophotometer and are reported in wavenumbers $\left(\mathrm{cm}^{-1}\right)$. Optical rotations were obtained with a digital polarimeter. Melting points (mp) were obtained from a melting-point apparatus and are reported uncorrected. High-resolution mass spectra were acquired on analytical chemical ionization (CI), electron ionization (EI), or electrospray ionization (ESI) spectrometer and were obtained by peak matching.

Analytical thin-layer chromatography (TLC) was performed using $0.25 \mathrm{~mm}$ precoated silica gel plates. Liquid chromatography was performed using forced flow (flash chromatography) of the indicated solvent system on silica gel $\left(\mathrm{SiO}_{2}\right) 60$ (200-400) mesh. Normal phase analytical high-pressure liquid chromatography (HPLC) was performed using a binary solvent delivery module, a $5 \mu \mathrm{m}(4.6 \times 250 \mathrm{~mm})$ silica column, and a UV-1 absorbance detector. Normal phase preparative HPLC was performed using a $7 \mu \mathrm{m}(21.2 \times 250 \mathrm{~mm})$ silica column and a UV-1 absorbance detector. Reverse phase analytical HPLC was performed using a binary solvent delivery module, a reverse-phase $\mathrm{C}_{18} 5 \mu \mathrm{m}(150 \times 4.6 \mathrm{~mm})$ column, and a photodiode array detector or on an LCMS system using a $\mathrm{C}_{18} 5 \mu \mathrm{m}(50 \times 4.6 \mathrm{~mm})$ column and a photodiode array detector and electrospray ionization detector. Reverse phase preparative HPLC was performed using binary solvent delivery module, BDX-C ${ }_{18} 10 \mu \mathrm{m}(100 \times 10 \mathrm{~mm})$ column, and a photodiode array detector or on a binary gradient LCMS System using a $\mathrm{C}_{18} 5 \mu \mathrm{m}(50 \times 20 \mathrm{~mm})$ column and a photodiode array detector and electrospray ionization detector.

All reactions were carried out using flame-dried or oven-dried glassware and inert 
atmosphere operations were conducted under $\mathrm{N}_{2}(\mathrm{~g})$ or $\mathrm{Ar}(\mathrm{g})$ passed through a Drierite drying tube. Anhydrous tetrahydrofuran (THF), methylene chloride $\left(\mathrm{CH}_{2} \mathrm{Cl}_{2}\right)$, triethylamine $\left(\mathrm{Et}_{3} \mathrm{~N}\right)$, acetonitrile $\left(\mathrm{CH}_{3} \mathrm{CN}\right)$, toluene, and diethyl ether $\left(\mathrm{Et}_{2} \mathrm{O}\right)$ were filtered through two columns of activated basic alumina and transferred under Ar (g) according to the method described by Grubbs. ${ }^{1}$ Diisopropyl amine was dried by distillation from $\mathrm{CaH}_{2}$ under nitrogen. $\mathrm{BF}_{3} \cdot \mathrm{OEt}_{2}$ was distilled from $\mathrm{CaH}_{2}$ under reduced pressure prior to use. ${ }^{2}$

Concentrations of organolithium reagents were established by titration in THF at $0{ }^{\circ} \mathrm{C}$ against 3,5-di-tert-butyl-4-hydroxytoluene/1,10-phenanthroline. Concentrations of Grignard reagents were established by titration in $\mathrm{THF}$ at $0{ }^{\circ} \mathrm{C}$ against sec- $\mathrm{BuOH} / 1,10$-phenanthroline according to the procedure of Watson and Eastman. ${ }^{3} N$-Bromosuccinimde (NBS) was recrystallized from water prior to use. ${ }^{2}$ Bromonium-sym-collidine hexafluorophosphorus $\left(\mathrm{Br}[\right.$ collidine $\left.] \mathrm{PF}_{6}\right)$ was prepared according to literature procedure. ${ }^{4}$ Trimethylsilylethoxy chloroformate $(\mathrm{TeocCl})$ was prepared as a solution in toluene according to the method of Rich and Shute. ${ }^{5}$ All other commercial reagents were used as received, unless noted otherwise.

\section{Experimental Procedures}

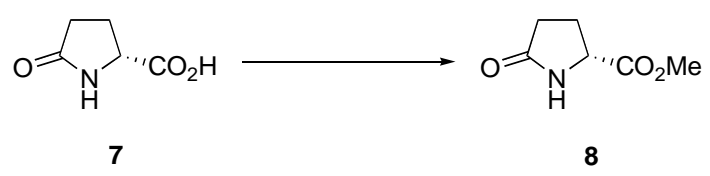

Lactam 8: To a cooled $\left(0{ }^{\circ} \mathrm{C}\right)$ solution of $(R)$-pyroglutamic acid (7) (25.1 g, $\left.0.194 \mathrm{~mol}\right)$ in $\mathrm{MeOH}(150 \mathrm{~mL})$ was added $\mathrm{SOCl}_{2}(0.700 \mathrm{~mL}, 0.010 \mathrm{~mol})$. The reaction mixture was allowed to warm to $25{ }^{\circ} \mathrm{C}$ overnight. Solid $\mathrm{NaHCO}_{3}$ (4.00 g) was added and the mixture was filtered through Celite. The Celite pad was washed with hot $\mathrm{MeOH}(3 \times 50 \mathrm{~mL})$ and the filtrate was concentrated in vacuo to afford a murky yellow oil that was dried under reduced pressure $(0.5$ $\mathrm{mmHg}$ ) for $16 \mathrm{~h}$. The resultant oil was purified by distillation under reduced pressure $(\mathrm{bp}=135-$ 
$\left.136{ }^{\circ} \mathrm{C}, 0.6 \mathrm{mmHg}\right)$ to yield lactam 8 as a colorless oil $(25.2 \mathrm{~g}, 88 \%):{ }^{1} \mathrm{H}$ NMR $(500 \mathrm{MHz}$, $\left.\mathrm{CDCl}_{3}\right) \delta 7.06$ (br s, 1H), $4.23(\mathrm{dd}, J=8.6,5.0,1 \mathrm{H}), 3.72(\mathrm{~s}, 3 \mathrm{H}), 2.46-2.26(\mathrm{~m}, 3 \mathrm{H}), 2.20-2.114$ (m, 1H); ${ }^{13} \mathrm{C} \mathrm{NMR}\left(125 \mathrm{MHz}, \mathrm{CDCl}_{3}\right) \delta 178.4,172.3,55.5,52.6$ 29.3, 24.8; IR (thin film) 3355, 3251, 2957, 1742, 1698, 1438, $1221 \mathrm{~cm}^{-1}$; HRMS $\left(\mathrm{CI} / \mathrm{CH}_{2} \mathrm{Cl}_{2}\right) \mathrm{m} / z$ calcd for $\mathrm{C}_{6} \mathrm{H}_{9} \mathrm{NO}_{3}\left(\mathrm{M}^{+}\right)$ 143.0582, found 143.0577; $[\alpha]_{\mathrm{D}}^{25}+1.8\left(c 2.07, \mathrm{CHCl}_{3}\right)$.

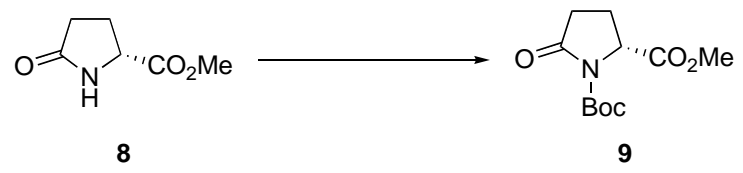

Imide 9: Imide 9 was synthesized by modifying a procedure described by Jain. ${ }^{6}$ Lactam 8 (25.2 g, $0.176 \mathrm{~mol})$ and DMAP $(2.20 \mathrm{~g}, 0.018 \mathrm{~mol}, 10 \mathrm{~mol} \%)$ were dissolved in $\mathrm{CH}_{3} \mathrm{CN}(150 \mathrm{~mL})$ at $25^{\circ} \mathrm{C}$. To this mixture was added $\mathrm{Boc}_{2} \mathrm{O}(40.0 \mathrm{~g}, 0.178 \mathrm{~mol})$ in two portions and the mixture was stirred for $18 \mathrm{~h}$. The resultant dark brown mixture was concentrated in vacuo to afford a brown oil that was partitioned between $1.0 \mathrm{~N} \mathrm{NaHSO}_{4}(75 \mathrm{~mL})$ and EtOAc $(200 \mathrm{~mL})$. The aqueous layer was extracted with EtOAc $(3 \times 250 \mathrm{~mL})$ and the combined organic extracts were washed with brine $(300 \mathrm{~mL})$, dried over $\mathrm{MgSO}_{4}$, and concentrated in vacuo to afford a brown solid. The resultant brown solid was recrystallized from 10:90 EtOAc/hexanes to yield imide $\mathbf{9}$ as clear crystals $(23.2 \mathrm{~g}, 88 \%): \mathrm{mp}=68-69{ }^{\circ} \mathrm{C} ;{ }^{1} \mathrm{H}$ NMR $\left(500 \mathrm{MHz}, \mathrm{CDCl}_{3}\right) \delta 4.58(\mathrm{dd}, J=9.4,3.1$, 1H), $3.76(\mathrm{~s}, 3 \mathrm{H}), 2.59(\mathrm{dt}, J=17.5,9.8,1 \mathrm{H}), 2.46(\mathrm{ddd}, J=13.4,9.4,3.7,1 \mathrm{H}), 2.29$ (d quint, $J$ $=13.4,9.8,1 \mathrm{H}), 2.00(\operatorname{dddd}, J=13.4,9.8,3.6,3.4,1 \mathrm{H}), 1.47(\mathrm{~s}, 9 \mathrm{H}) ;{ }^{13} \mathrm{C}$ NMR $(125 \mathrm{MHz}$ $\left.\mathrm{CDCl}_{3}\right) \delta 173.5,172.2,149.7,84.0,59.2,52.9,31.5,28.3,21.9$; IR (KBr) 2997, 2962, 2929, 1760, 1740, 1703, 1441, 1380, 1315, $1147 \mathrm{~cm}^{-1}$; HRMS $\left(\mathrm{CI} / \mathrm{CH}_{2} \mathrm{Cl}_{2}\right) \mathrm{m} / z$ calcd for $\mathrm{C}_{11} \mathrm{H}_{17} \mathrm{NO}_{5}$ $\left(\mathrm{M}-\mathrm{CH}_{3}\right)^{+} 228.0872$, found 228.0872; $[\alpha]_{\mathrm{D}}^{25}+31.7$ ( c 3.37, $\left.\mathrm{CHCl}_{3}\right)$. 


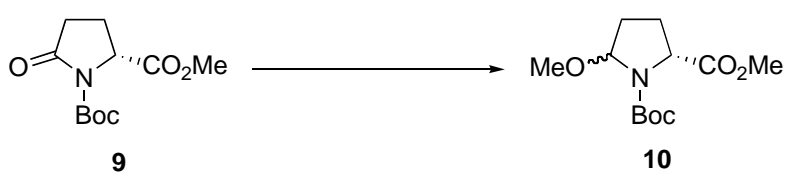

Aminal 10: Aminal 10 was synthesized using a similar method described by Esquerra. ${ }^{7}$ To a cooled $\left(-78^{\circ} \mathrm{C}\right)$ solution of imide $9(11.4 \mathrm{~g}, 46.8 \mathrm{mmol})$ in THF $(250 \mathrm{~mL})$ was added lithium triethylborohydride $\left(50.0 \mathrm{~mL}, 50.0 \mathrm{mmol}, 1.0 \mathrm{M} \mathrm{LiBHEt}_{3}\right.$ in THF) dropwise by syringe. After 1 h at $-78{ }^{\circ} \mathrm{C}$, saturated aqueous $\mathrm{NaHCO}_{3}(100 \mathrm{~mL})$ was added and the mixture was allowed to warm to $0{ }^{\circ} \mathrm{C}$. Aqueous $\mathrm{H}_{2} \mathrm{O}_{2}(15$ drops, $30 \mathrm{w} / \mathrm{w} \%)$ was added and the mixture was stirred for 30 min. The layers were separated and the aqueous layer was extracted with $\mathrm{Et}_{2} \mathrm{O}(3 \times 100 \mathrm{~mL})$. The combined organic layers were washed with brine $(50 \mathrm{~mL})$, dried $\left(\mathrm{MgSO}_{4}\right)$, and concentrated in vacuo to afford the hemi-aminal as a clear oil. The resultant oil was diluted with methanol (250 $\mathrm{mL})$ and treated with $p$-TsOH $(0.130 \mathrm{~g}, 0.683 \mathrm{mmol})$ at room temperature. After $24 \mathrm{~h}$, saturated aqueous sodium bicarbonate $(100 \mathrm{~mL})$ was added and the reaction mixture was concentrated in vacuo to $1 / 3$ its volume. The mixture was diluted with $\mathrm{H}_{2} \mathrm{O}(200 \mathrm{~mL})$ and extracted with $\mathrm{Et}_{2} \mathrm{O}(3$ x $100 \mathrm{~mL}$ ). The combined organic extracts were dried over $\mathrm{MgSO}_{4}$ and concentrated in vacuo to provide a yellow oil. The oil was purified by flash chromatography (30:70 EtOAc:hexanes) to give 10 as a clear colorless oil (11.6 g, 95\%, 1:1 mixture of cis/trans diastereomers): ${ }^{1} \mathrm{H}$ NMR (500 MHz, DMSO-d $\left.d_{6}, 375 \mathrm{~K}\right) \delta 5.51(\mathrm{~m}, 2 \mathrm{H}), 4.24(\mathrm{~m}, 2 \mathrm{H}), 3.67$ (s, 3H), 3.66 (br s, 3H), 3.31 (s, $3 \mathrm{H}), 3.28(\mathrm{~s}, 3 \mathrm{H}), 2.27-2.32(\mathrm{~m}, 2 \mathrm{H}), 2.00-1.79(\mathrm{~m}, 4 \mathrm{H}), 1.42(\mathrm{~s}, 9 \mathrm{H}), 1.40(\mathrm{br} \mathrm{s}, 9 \mathrm{H}) ;{ }^{13} \mathrm{C} \mathrm{NMR}$ (125 MHz, $\mathrm{CDCl}_{3}$, reported as a 1:1 mixture of trans- and cis-diastereomers and as a mixture of rotamers at $298 \mathrm{~K}) \delta 173.3,173.0,154.3,154.1,154.0,153.9,89.3,89.2,88.5,88.4,80.9,80.8$, $80.6,80.5,59.6,59.3,58.9,58.8,56.2,55.9,55.4,55.0,52.2,52.1,52.0,51.9,32.9,32.2,31.1$, $30.1,28.3,28.3,28.2,28.0,28.0,27.1,27.0$; IR (thin film) 2978, 2950, 1759, 1738, $1691 \mathrm{~cm}^{-1}$; HRMS $\left(\mathrm{CI} / \mathrm{CH}_{2} \mathrm{Cl}_{2}\right) m / z$ calcd for $\mathrm{C}_{12} \mathrm{H}_{21} \mathrm{NO}_{5}\left(\mathrm{M}-\mathrm{CH}_{3} \mathrm{OH}\right)^{+} 227.1158$, found 227.1158. 


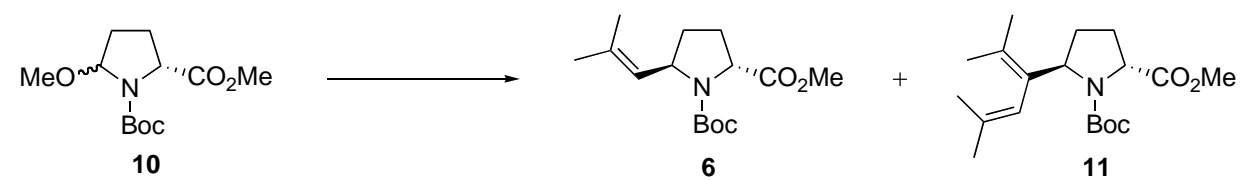

Pyrrolidine 6: A three-neck flask fitted with a reflux condenser and an addition funnel was charged with $\operatorname{Mg}(0)$ turnings $(3.14 \mathrm{~g}, 129 \mathrm{mmol})$ and THF $(25 \mathrm{~mL})$. To the vigorously stirred suspension under $\operatorname{Ar}(\mathrm{g})$ was slowly added 1-bromo-2-methylpropene (1.00 mL, $6.35 \mathrm{mmol}, 6.35$ M solution in THF), followed by 1,2-dibromoethane $(0.50 \mathrm{~mL}, 5.80 \mathrm{mmol})$. After the initiation of an exothermic reaction, additional 1-bromo-2-methylpropene $(9.00 \mathrm{~mL}$, total volume: 10.0 $\mathrm{mL}, 63.5 \mathrm{mmol}, 6.35 \mathrm{M}$ solution in THF) was added at a rate of $1 \mathrm{~mL} / 3 \mathrm{~min}$. The resultant dark brown mixture was allowed to stir at $40{ }^{\circ} \mathrm{C}$ for $2 \mathrm{~h}$ and then cooled to $25{ }^{\circ} \mathrm{C}$. The reaction mixture turned heterogeneous upon cooling to room temperature and was diluted with THF (150 $\mathrm{mL})$. The Grignard reagent was transferred via cannula to a cooled $\left(-45^{\circ} \mathrm{C}\right)$ suspension of $\mathrm{CuBr}$-DMS $(14.0 \mathrm{~g}, 68.1 \mathrm{mmol})$ in $\mathrm{Et}_{2} \mathrm{O}(60 \mathrm{~mL})$. After $1 \mathrm{~h}$, the mixture was cooled to $-78{ }^{\circ} \mathrm{C}$, followed by addition of $\mathrm{BF}_{3} \cdot \mathrm{OEt}_{2}(7.80 \mathrm{~mL}, 63.4 \mathrm{mmol})$ and a solution of $\mathbf{1 0}(3.94 \mathrm{~g}, 15.2 \mathrm{mmol})$ in $\mathrm{Et}_{2} \mathrm{O}(20 \mathrm{~mL})$. The reaction was allowed to warm gradually to $0{ }^{\circ} \mathrm{C}$ over a period of $5 \mathrm{~h}$ and was maintained at $0{ }^{\circ} \mathrm{C}$ for an additional hour. A solution of $\mathrm{NH}_{4} \mathrm{OH}: \mathrm{NH}_{4} \mathrm{Cl}(1: 1$ mixture, 40 $\mathrm{mL}$ ) was added and the mixture was stirred vigorously for $2 \mathrm{~h}$. The organic layer was removed and the blue aqueous phase was extracted with $\mathrm{Et}_{2} \mathrm{O}(3 \times 100 \mathrm{~mL})$. The combined organic extracts were washed with brine $(2 \times 100 \mathrm{~mL})$, dried over $\mathrm{MgSO}_{4}$, and concentrated in vacuo to provide a dark yellow oil. ${ }^{1} \mathrm{H}$ NMR analysis of unpurified material revealed d.r. $($ trans-6:cis-6) $=$ 30:1. The resultant oil was purified by flash chromatography (gradient elution 8:92 - 15:85 20:80 EtOAc:hexanes) to yield $\mathbf{6}$ as a pale yellow oil $(3.0 \mathrm{~g}, 70 \%$, d.r. $($ trans-6:cis-6) $=>20: 1)$ :

trans-6: ${ }^{1} \mathrm{H}$ NMR $\left(500 \mathrm{MHz}, \mathrm{DMSO}-d_{6}, 398 \mathrm{~K}\right) \delta 5.11$ (app. dsep, $\left.J=9.0,1.4,1 \mathrm{H}\right), 4.55(\operatorname{td}, J=$ 8.5, 2.4, 1H), $4.25(\mathrm{dd}, J=11.1,2.3,1 \mathrm{H}), 3.66(\mathrm{~s}, 3 \mathrm{H}), 2.27$ (m, 1H), $2.10(\mathrm{~m}, 1 \mathrm{H}), 1.84$ (dddd, $J$ 
$=12.0,9.3,2.5,2.4,1 \mathrm{H}), 1.69(\mathrm{~d}, J=1.2,3 \mathrm{H}), 1.67(\mathrm{~d}, J=1.2,3 \mathrm{H}), 1.54(\mathrm{dddd}, J=12.4,9.4$, 2.5, 2.4, 1H), $1.35(\mathrm{~s}, 9 \mathrm{H}) ;{ }^{13} \mathrm{C} \mathrm{NMR}\left(125 \mathrm{MHz}, \mathrm{CDCl}_{3}\right.$, reported as a mixture of rotamers at 298 К) $\delta 174.0,173.6,154.7,153.6,133.0,131.7,126.4,126.3,79.7,79.6,59.7,59.3,56.0,55.9$, $52.2,52.0,31.8,31.1,29.1,28.5,28.4,28.1,25.9,25.7,18.2,18.1$; IR (thin film) 2974, 2932, 1750, 1708, 1696, 1449, 1391, 1171, $1121 \mathrm{~cm}^{-1}$; HRMS (ESI/methanol) $m / z$ calcd for $\mathrm{C}_{15} \mathrm{H}_{25} \mathrm{NO}_{4}\left(\mathrm{M}^{+}\right)$283.1784, found 283.1772; $[\alpha]^{25}+3.0\left(\right.$ c 2.89, $\left.\mathrm{CHCl}_{3}\right)$.

trans-11: ${ }^{1} \mathrm{H}$ NMR (500 MHz, DMSO-d $\left.d_{6}, 395.0 \mathrm{~K}\right) \delta 5.46($ br s, $1 \mathrm{H}), 4.84(\mathrm{dd}, J=8.3,2.5,1 \mathrm{H})$, $4.15(\mathrm{dd}, J=8.7,2.7,1 \mathrm{H}), 3.66(\mathrm{~s}, 3 \mathrm{H}), 2.23-2.12(\mathrm{~m}, 2 \mathrm{H}), 1.83-1.77(\mathrm{~m}, 1 \mathrm{H}$ and $\mathrm{d}, J=1.7$, $3 \mathrm{H}), 1.75(\mathrm{~d}, J=1.3,3 \mathrm{H}), 1.61(\mathrm{~m}, 1 \mathrm{H}), 1.56(\mathrm{~s}, 3 \mathrm{H}), 1.50(\mathrm{~s}, 3 \mathrm{H}), 1.36(\mathrm{~s}, 9 \mathrm{H}) ;{ }^{13} \mathrm{C}$ NMR $(125$ $\mathrm{MHz}, \mathrm{CDCl}_{3}$, reported as a mixture of rotamers at $\left.298 \mathrm{~K}\right) \delta 173.3,172.9,153.5,152.4,135.3$, $135.1,132.2,132.2,127.1,126.7,122.2,121.9,78.7,78.5,59.6,59.6,58.3,58.1,51.8,51.7$, $30.4,29.8,29.0,28.1,28.0,27.9,25.0,25.0,22.2,22.2,19.3,19.3,19.3,19.1$; IR (thin film) 2970, 2821, 1754, 1704, 1696, 1449, 1375, 1175, 1126, $763 \mathrm{~cm}^{-1}$; HRMS (ESI/methanol) $\mathrm{m} / \mathrm{z}$ calcd for $\mathrm{C}_{19} \mathrm{H}_{31} \mathrm{NO}_{4}(\mathrm{M}+\mathrm{Na})^{+} 360.2151$, found 360.2142; $[\alpha]^{26}{ }_{\mathrm{D}}+109\left(c 2.70, \mathrm{CHCl}_{3}\right)$.

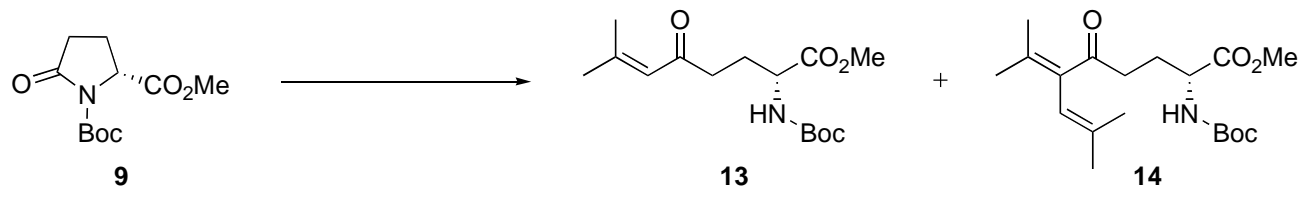

Enone 13: To a solution of 2-methyl-1-propenylmagnesium bromide (50.0 mL, $25.0 \mathrm{mmol}, 0.5$ $\mathrm{M}$ in THF) was added TMEDA $(4.00 \mathrm{~mL}, 26.5 \mathrm{mmol})$ at room temperature and the reaction mixture was stirred for $30 \mathrm{~min}$. The resulting was added to a cooled $\left(-78^{\circ} \mathrm{C}\right)$ solution of $9(5.35$ $\mathrm{g}, 22.0 \mathrm{mmol})$ in THF (30 mL). After $15 \mathrm{~min}, i-\mathrm{PrOH}(20 \mathrm{~mL})$ was added, and after an additional 15 min saturated aqueous $\mathrm{NH}_{4} \mathrm{Cl}(50 \mathrm{~mL})$ was added and the reaction mixture was warmed to 0 ${ }^{\circ} \mathrm{C}$. The temperature was maintained at $0{ }^{\circ} \mathrm{C}$ for $45 \mathrm{~min}$. The reaction mixture was diluted with $\mathrm{H}_{2} \mathrm{O}(100 \mathrm{~mL})$ and extracted with EtOAc $(3 \times 100 \mathrm{~mL})$. The combined organic extracts were 
washed with $1.0 \mathrm{~N} \mathrm{HCl}(100 \mathrm{~mL})$, brine $(100 \mathrm{~mL})$, dried over $\mathrm{MgSO}_{4}$, and concentrated in vacuo to give a red oil. The oil was purified by flash chromatography (5:95 - 10:90 EtOAc:hexanes) to yield enone $\mathbf{1 3}$ as white solids (5.15, 78\%) and dienyl enone $\mathbf{1 4}$ as an oil (0.200 g, 2.6\%). Enone 13 was recrystallized from 10:90 EtOAc:hexanes to give white shiny needle like crystals:

Enone 13: $\mathrm{mp}=63-68{ }^{\circ} \mathrm{C} ;{ }^{1} \mathrm{H}$ NMR $\left(500 \mathrm{MHz}, \mathrm{DMSO}_{6}, 375 \mathrm{~K}\right) \delta 6.57(\mathrm{br} \mathrm{d}, J=5.5,1 \mathrm{H})$, 6.10 (app sep, $J=1.3,1 \mathrm{H}), 4.02$ (td, $J=8.3,5.6,1 \mathrm{H}), 3.65(\mathrm{~s}, 3 \mathrm{H}), 2.49-2.45(\mathrm{~m}, 2 \mathrm{H}), 2.07$ (d, $J$ $=1.1,3 \mathrm{H}), 2.01-2.94(\mathrm{~m}, 1 \mathrm{H}), 1.87(\mathrm{~d}, J=1.2,3 \mathrm{H}), 1.86-1.80(\mathrm{~m}, 1 \mathrm{H}), 1.40(\mathrm{~s}, 9 \mathrm{H}) ;{ }^{13} \mathrm{C} \mathrm{NMR}$ $\left(125 \mathrm{MHz}, \mathrm{CDCl}_{3}\right) \delta 199.3,173.1,155.9,155.5,123.5,79.9,53.2,52.4,39.9,28.3,27.8,26.7$, 20.9; IR (thin film) 3361, 3008, 2977, 2934, 1747, 1715, 1693, 1621, 1515, 1446, 1366, 1167 $\mathrm{cm}^{-1}$; HRMS (ESI/methanol) $\mathrm{m} / z$ calcd for $\mathrm{C}_{15} \mathrm{H}_{25} \mathrm{NO}_{5}(\mathrm{M}+\mathrm{Na})^{+}$322.1631, found 322.1628; $[\alpha]^{23}{ }_{\mathrm{D}}+25.4\left(c 0.68, \mathrm{CHCl}_{3}\right)$.

Dienone 14: ${ }^{1} \mathrm{H}$ NMR (500 MHz, DMSO- $\left.d_{6}, 375 \mathrm{~K}\right) \delta 6.59$ (br d, $J=5.5,1 \mathrm{H}$ ), 5.80 (app septet, $J=1.4,1 \mathrm{H}), 4.01($ app td, $J=8.4,5.5,1 \mathrm{H}), 3.65(\mathrm{~s}, 3 \mathrm{H}), 2.56-2.44(\mathrm{~m}, 2 \mathrm{H}), 1.96$ (dddd, $J=$ $14.9,8.0,6.9,5.5,1 \mathrm{H}), 1.84(\mathrm{~d}, J=1.6,3 \mathrm{H}), 1.82-1.76(\mathrm{~d}, J=1.3,3 \mathrm{H}$ and $\mathrm{m}, 1 \mathrm{H}), 1.68(\mathrm{~d}, J=$ $0.9,3 \mathrm{H}), 1.51(\mathrm{~d}, J=1.1,3 \mathrm{H}), 1.40(\mathrm{~s}, 9 \mathrm{H}) ;{ }^{13} \mathrm{C} \mathrm{NMR}\left(125 \mathrm{MHz}, \mathrm{CDCl}_{3}\right) \delta 204.4,173.1,155.5$, $142.6,137.8,134.3,121.2,79.8,53.2,52.3,38.2,28.3,26.6,25.4,22.8,21.9,19.2$; IR (thin film) $3373,2972,2932,1747,1715,1694,1606,1505,1446,1367,1251,1164 \mathrm{~cm}^{-1}$; HRMS (ESI/methanol) $m / z$ calcd for $\mathrm{C}_{19} \mathrm{H}_{31} \mathrm{NO}_{5}(\mathrm{M}+\mathrm{Na})^{+} 376.2100$, found $376.2100 ;[\alpha]^{23}{ }_{\mathrm{D}}-14.6(c$ $\left.0.23, \mathrm{CHCl}_{3}\right)$.

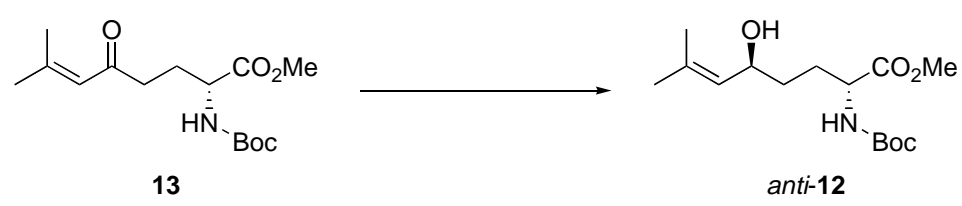

Allylic Alcohol anti-12: To $(R)$-methyl-CBS $(11.0 \mathrm{~mL}, 11.0 \mathrm{mmol}, 1.0 \mathrm{M}$ in toluene) in THF $(10 \mathrm{~mL})$ was added $\mathrm{BH}_{3} \cdot \mathrm{DMS}(0.920 \mathrm{~mL}, 9.70 \mathrm{mmol})$ at room temperature. After $15 \mathrm{~min}$, the 
reaction mixture was cooled $\left(-78{ }^{\circ} \mathrm{C}\right)$ and a solution of enone $\mathbf{1 3}(2.66 \mathrm{~g}, 8.89 \mathrm{mmol})$ in THF $(12$ $\mathrm{mL}$ ) was added dropwise. The reaction mixture was allowed to warm to room temperature over an $8 \mathrm{~h}$ period. The reaction was quenched with $\mathrm{MeOH}(30 \mathrm{~mL})$ and the mixture was stirred for 30 min before saturated $\mathrm{NaHCO}_{3}(75 \mathrm{~mL})$ was added. After $15 \mathrm{~min}, \mathrm{H}_{2} \mathrm{O}(75 \mathrm{~mL})$ was added and the mixture was extracted with EtOAc $(3 \times 75 \mathrm{~mL})$. The combined organic extracts were washed with $1.0 \mathrm{~N} \mathrm{HCl}(20 \mathrm{~mL})$, saturated $\mathrm{NaHCO}_{3}(50 \mathrm{~mL})$, brine $(75 \mathrm{~mL})$, dried over $\mathrm{MgSO}_{4}$, and concentrated in vacuo to give a yellow oil. Normal phase HPLC analysis (10:90 $i$-PrOH:hexanes, $1.0 \mathrm{~mL} / \mathrm{min}, 220 \mathrm{~nm})$ of the unpurified material revealed d.r. $($ anti-12:syn-12 $)=14.0: 1.0$. The oil was purified by flash chromatography (gradient elution 10:90 - 20:80 - 30:70 - 100:0 EtOAc:hexanes) to yield anti-12 a clear oil $\left(2.13 \mathrm{~g}, 79 \%\right.$, d.r. $($ anti-12:syn-12) $=14.0: 1.0):{ }^{1} \mathrm{H}$ NMR (500 MHz, DMSO- $\left.d_{6}, 385 \mathrm{~K}\right) \delta 6.43$ (br s, 1H), 5.12 (d sep, $\left.J=8.3,1.4,1 \mathrm{H}\right), 4.19-4.14$ (m, 1H), $3.99(\mathrm{td}, J=8.0,5.7,1 \mathrm{H}), 3.86(\mathrm{~d}, J=4.6,1 \mathrm{H}), 3.65(\mathrm{~s}, 3 \mathrm{H}), 1.78(\mathrm{dddd}, J=13.7,9.8$, 5.7, 5.7, 1H), $1.69(\mathrm{~d}, J=1.3,3 \mathrm{H}), 1.68-1.59(\mathrm{~d}, J=1.3,3 \mathrm{H}$ and $\mathrm{m}, 1 \mathrm{H}), 1.53-1.41(\mathrm{~m}, 2 \mathrm{H}$ and $\mathrm{s}, 9 \mathrm{H}) ;{ }^{13} \mathrm{C} \mathrm{NMR}\left(125 \mathrm{MHz}, \mathrm{CDCl}_{3}\right) \delta 173.4,155.5,135.7,127.6,80.0,68.2,53.3,52.3,33.2$, 29.0, 28.4, 25.8, 18.3; IR (thin film) 3439, 2270, 2975, 2931, 2873, 1743, 1715, 1519, 1451, 1391, 1366, 1251, $1167 \mathrm{~cm}^{-1}$; HRMS (ESI/methanol) $m / z$ calcd for $\mathrm{C}_{15} \mathrm{H}_{27} \mathrm{NO}_{5}(\mathrm{M}+\mathrm{Na})^{+}$ 324.1787, found 324.1784; $[\alpha]^{23}-26.8\left(c 1.10, \mathrm{CHCl}_{3}\right)$.

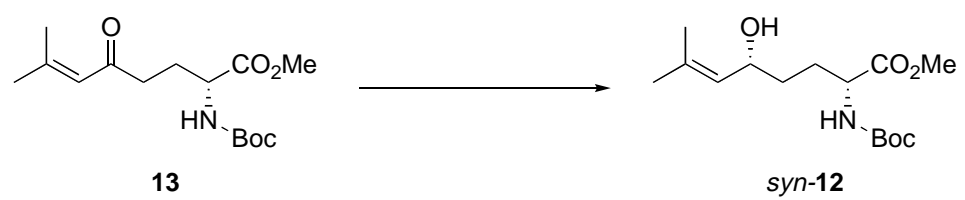

Allylic Alcohol syn-12: To $(S)$-methyl-CBS (1.20 mL, $1.20 \mathrm{mmol}, 1.0 \mathrm{M}$ in toluene) in THF (10 $\mathrm{mL})$ was added $\mathrm{BH}_{3} \cdot \mathrm{THF}(1.00 \mathrm{~mL}, 1.00 \mathrm{mmol}, 1.0 \mathrm{M}$ in THF) at room temperature. After 15 min, the reaction mixture was cooled $\left(-78^{\circ} \mathrm{C}\right)$ and a solution of enone $\mathbf{1 3}(0.300 \mathrm{~g}, 1.00 \mathrm{mmol})$ in THF (12 mL) was added dropwise. The reaction mixture was allowed to warm to room 
temperature over an $8 \mathrm{~h}$ period. The reaction was quenched with $\mathrm{MeOH}(10 \mathrm{~mL})$ and the mixture was stirred for $30 \mathrm{~min}$, before saturated $\mathrm{NaHCO}_{3}(25 \mathrm{~mL})$ was added. After $15 \mathrm{~min}, \mathrm{H}_{2} \mathrm{O}$ (50 $\mathrm{mL})$ was added and the mixture was extracted with EtOAc $(3 \times 50 \mathrm{~mL})$. The combined organic extracts were washed with aqueous $1.0 \mathrm{~N} \mathrm{HCl}(10 \mathrm{~mL})$, saturated $\mathrm{NaHCO}_{3}(25 \mathrm{~mL})$, brine $(50$ $\mathrm{mL}$ ), dried over $\mathrm{MgSO}_{4}$, and concentrated in vacuo to give a yellow oil. Normal phase HPLC analysis (10:90 $i$-PrOH:hexanes, $1.0 \mathrm{~mL} / \mathrm{min}, 220 \mathrm{~nm})$ of the unpurified material revealed a d.r. $($ anti-12:syn-12) $=1.0: 33.0$. The oil was purified by flash chromatography (gradient elution 10:90 - 20:80 - 30:70 - 100:0 EtOAc:hexanes) to yield syn-12 as white fluffy solids $(0.123 \mathrm{~g}$, $41 \%$, d.r. $\left(\right.$ anti-13:syn-13) = 1.0:33.0); ${ }^{1} \mathrm{H}$ NMR (400 MHz, DMSO- $\left.d_{6}, 385 \mathrm{~K}\right) \delta 6.50$ (br d, $J=$ $5.7,1 \mathrm{H}), 5.11(\mathrm{~d} \operatorname{sep}, J=10.3,1.7,1 \mathrm{H}), 4.20-4.14(\mathrm{~m}, 1 \mathrm{H}), 4.01(\mathrm{td}, J=8.2,5.6,1 \mathrm{H}), 3.94(\mathrm{~d}, J$ $=4.3,1 \mathrm{H}), 3.65(\mathrm{~s}, 3 \mathrm{H}), 1.78-1.67(\mathrm{~m}, 2 \mathrm{H}$ and $\mathrm{d}, J=1.7,3 \mathrm{H}), 1.67-1.63(\mathrm{~d}, J=1.6,3 \mathrm{H}), 1.52-$ $1.45(\mathrm{~m}, 1 \mathrm{H}), 1.44-1.40(\mathrm{~m}, 1 \mathrm{H}$ and $\mathrm{s}, 9 \mathrm{H}) ;{ }^{13} \mathrm{C} \mathrm{NMR}\left(125 \mathrm{MHz}, \mathrm{CDCl}_{3}\right) \delta 173.5,155.5,135.6$ 127.6, 79.9, 68.0, 53.3, 52.3, 33.1, 28.7, 28.3, 25.8, 18.3; IR (thin film) 3431, 3357, 3003, 2976, 2875, 1743, 1715, 1508, 1451, 1392, 1367, $1167 \mathrm{~cm}^{-1}$; HRMS (ESI/methanol) $\mathrm{m} / z$ calcd for $\mathrm{C}_{15} \mathrm{H}_{27} \mathrm{NO}_{5}(\mathrm{M}+\mathrm{Na})^{+} 324.1787$, found 324.1786; $[\alpha]^{25}+4.2\left(c 0.215, \mathrm{CHCl}_{3}\right)$.

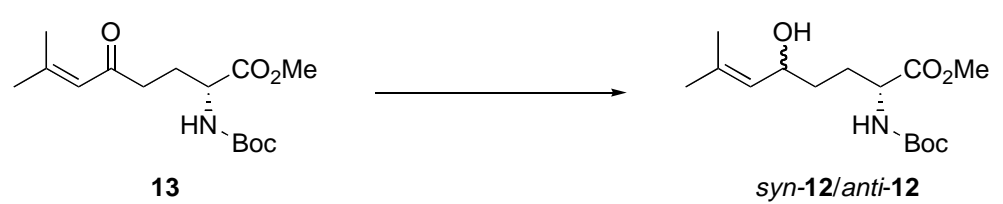

Allylic Alcohols anti-/syn-12: To a stirred solution of enone 13 (0.756 g, $2.52 \mathrm{mmol})$ in $\mathrm{MeOH}$ (45 mL) was added in one portion $\mathrm{CeCl}_{3} \cdot 7 \mathrm{H}_{2} \mathrm{O}(1.04 \mathrm{~g}, 2.79 \mathrm{mmol})$. The reaction mixture was cooled $\left(-78{ }^{\circ} \mathrm{C}\right)$ and $\mathrm{NaBH}_{4}(0.272 \mathrm{~g}, 7.19 \mathrm{mmol})$ was added in three portions. After $5 \mathrm{~min}, \mathrm{pH} 7$ phosphate buffer was added $(20 \mathrm{~mL})$ and the reaction mixture was warmed to room temperature. The reaction mixture was extracted with EtOAc $(3 \times 25 \mathrm{~mL})$ and the combined organic extracts were washed with brine $(50 \mathrm{~mL})$, dried over $\mathrm{MgSO}_{4}$, and concentrated in vacuo. The resultant 
solid was purified by flash chromatography (gradient elution 10:90 - 20:80 - 30:70 - 50:50 EtOAc:hexanes) to yield an inseparable mixture of anti-12 and syn-12 as a clear oil (0.618 g, $81 \%, 1: 1$ inseparable mixture of diastereomers).

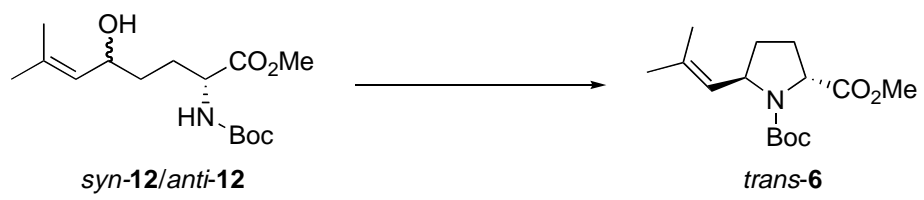

Pyrrolidine trans-6: To a solution containing $\mathrm{Ph}_{3} \mathrm{P}(1.24 \mathrm{~g}, 2.51 \mathrm{mmol})$ and imidazole $(0.634 \mathrm{~g}$, $9.31 \mathrm{mmol})$ in THF $(32 \mathrm{~mL})$ was added $\mathrm{I}_{2}(1.18 \mathrm{~g}, 4.65 \mathrm{mmol})$ in three portions. The reaction mixture was stirred at room temperature for $2 \mathrm{~h}$, at which point precipitate formation was observed. The heterogeneous mixture was cooled $\left(-78{ }^{\circ} \mathrm{C}\right)$ and a solution of allylic alcohol $\mathbf{1 2}$ $(0.558 \mathrm{~g}, 1.85 \mathrm{mmol}$, d.r. $($ anti-12:syn-12 $)=1: 1)$ in THF $(10 \mathrm{~mL})$ was added. The reaction mixture was allowed to warm slowly to room temperature over $8 \mathrm{~h}$ and stirred at room temperature for an additional $10 \mathrm{~h}$, at which point TLC (30:70 EtOAc:hexanes) analysis showed consumption of starting material. The heterogeneous solution was quenched by the addition of saturated aqueous $\mathrm{Na}_{2} \mathrm{~S}_{2} \mathrm{O}_{3}(10 \mathrm{~mL})$ and stirred for $30 \mathrm{~min}$. The bi-phasic mixture was extracted with $\mathrm{Et}_{2} \mathrm{O}(3 \times 20 \mathrm{~mL})$, washed with $1.0 \mathrm{~N} \mathrm{HCl}(2 \times 20 \mathrm{~mL})$, brine $(25 \mathrm{~mL})$, dried over $\mathrm{MgSO}_{4}$, and concentrated to give white solids. The solids were suspended in pentanes $(50 \mathrm{~mL})$, vigorously stirred for $15 \mathrm{~min}$, and filtered over a pad of Celite. The Celite pad was washed with pentanes $(3 \times 25 \mathrm{~mL})$ and the filtrate was concentrated to provide clear oil. Normal phase HPLC analysis (1:99 $i$-PrOH:hexanes, $1.0 \mathrm{~mL} / \mathrm{min}, 220 \mathrm{~nm})$ of the unpurified material revealed d.r. $($ trans-6:cis-6) $=13.9: 1.00$. Purification by flash chromatography (gradient elution 8:92 - 20:80 EtOAc:hexanes) yielded trans-6 as a clear oil $(0.390 \mathrm{~g}, 74 \%$, d.r. $($ trans-6:cis-6) $=14.0: 1.00)$. 
Preparation of $N$-Boc Serine Ester 27
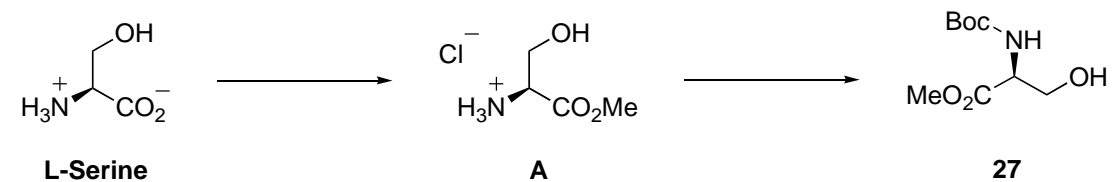

$N$-Boc Serine Ester 27: To a cooled $\left(0{ }^{\circ} \mathrm{C}\right)$ suspension of L-serine $(30.2 \mathrm{~g}, 0.287 \mathrm{~mol})$ in $\mathrm{MeOH}$ $(200 \mathrm{~mL})$ was slowly added $\mathrm{SOCl}_{2}(24.0 \mathrm{~mL}, 0.329 \mathrm{~mol})$ using an addition funnel at a rate of 1.0 $\mathrm{mL} / 5 \mathrm{~min}$. The reaction mixture was allowed to warm to $25^{\circ} \mathrm{C}$ and stirred for $24 \mathrm{~h}$. The solvent was removed in vacuo to provide a white solid. Excess $\mathrm{HCl}$ was azeotropically removed with $\mathrm{MeOH}(3 \times 50 \mathrm{~mL})$, followed by hexanes $(3 \times 50 \mathrm{~mL})$. The resultant solid was dried under reduced pressure $(0.5 \mathrm{mmHg})$ for $24 \mathrm{~h}$ to yield ester $\mathbf{A}$ as a crystalline solid $(44.7 \mathrm{~g}, 100 \%):{ }^{1} \mathrm{H}$ NMR (500 MHz, DMSO- $\left.d_{6}\right) \delta 8.61(\mathrm{br} \mathrm{s}, 3 \mathrm{H}), 5.63(\mathrm{br} \mathrm{s}, 1 \mathrm{H}), 4.08(\mathrm{t}, J=3.5,1 \mathrm{H}), 3.82$ (app. br s, $1 \mathrm{H}), 3.73(\mathrm{~s}, 3 \mathrm{H}) ;{ }^{13} \mathrm{C}$ NMR (125 MHz, DMSO- $\left.d_{6}\right) \delta 168.5,59.5,54.5,52.7$; IR (KBr) 3366, $3350,3342,2936,2552,1757,1740,1595,1515,582 \mathrm{~cm}^{-1} ;[\alpha]^{26}{ }_{\mathrm{D}}+4.6(c 2.89, \mathrm{MeOH})$.

To a cooled $\left(0{ }^{\circ} \mathrm{C}\right)$ solution of ester $\mathbf{A}(23.3 \mathrm{~g}, 0.150 \mathrm{~mol})$ in THF/water (3:1 mixture, 100 $\mathrm{mL})$ was added anhydrous $\mathrm{K}_{2} \mathrm{CO}_{3}(36.0 \mathrm{~g}, 0.160 \mathrm{~mol})$ and $\mathrm{Boc}_{2} \mathrm{O}(23.7 \mathrm{~g}, 0.171 \mathrm{~mol})$. The reaction mixture was stirred vigorously for $24 \mathrm{~h}$ at room temperature. The resultant bi-phasic mixture was cooled $\left(0{ }^{\circ} \mathrm{C}\right)$ and acidified to $\mathrm{pH} 1.0$ using $1.0 \mathrm{~N} \mathrm{HCl}$. The layers were separated and the aqueous phase was extracted with EtOAc $(3 \times 150 \mathrm{~mL})$. The combined organic layers were washed with brine $(50 \mathrm{~mL})$, dried over $\mathrm{MgSO}_{4}$, and concentrated in vacuo to afford a yellow oil. The resultant oil was purified by distillation under reduced pressure ( $\mathrm{bp}=150-153$ ${ }^{\circ} \mathrm{C}, 0.7 \mathrm{mmHg}$, lit. $126{ }^{\circ} \mathrm{C}, 0.3 \mathrm{mmHg}$ ) to yield 27 as a colorless oil $(26.2 \mathrm{~g}, 80 \%):{ }^{1} \mathrm{H}$ NMR (500 MHz, DMSO- $\left.d_{6}\right) \delta 6.64($ br s, $1 \mathrm{H}), 4.74(\mathrm{t}, J=6.0,1 \mathrm{H}), 3.79$ (app. br s, $\left.1 \mathrm{H}\right), 3.65$ (s, 3H and m, 2H), $1.39(\mathrm{~s}, 9 \mathrm{H}) ;{ }^{13} \mathrm{C}$ NMR (125 MHz, DMSO- $\left.d_{6}\right) \delta 171.8,155.3,78.3,61.3,56.2,51.7,28.1$; 
IR (thin film) 3386, 2978, 1746, 1718, 1698, 1522, 1368, $1164 \mathrm{~cm}^{-1} ; \mathrm{HRMS}\left(\mathrm{CI} / \mathrm{CH}_{2} \mathrm{Cl}_{2}\right) \mathrm{m} / z$ calcd for $\mathrm{C}_{9} \mathrm{H}_{17} \mathrm{NO}_{5}(\mathrm{M}-\mathrm{OH})^{+} 202.1079$, found 202.1086; $[\alpha]^{26}{ }_{\mathrm{D}}+9.7\left(c 4.29, \mathrm{CHCl}_{3}\right)$.

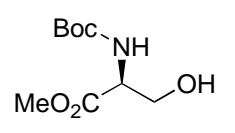

27

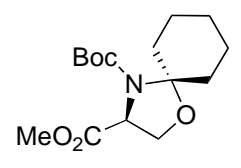

28

N,O-Acetal 28: To a solution of $27(16.4 \mathrm{~g}, 74.8 \mathrm{~mol})$ in $\mathrm{CH}_{2} \mathrm{Cl}_{2}(50 \mathrm{~mL})$ was added 2,2-dimethoxycyclohexane $(60 \mathrm{~mL})$ and cylcohexanone $(60 \mathrm{~mL})$. To this solution was added $\mathrm{BF}_{3} \cdot \mathrm{OEt}_{2}(1.00 \mathrm{~mL}, 8.13 \mathrm{mmol})$. After $16 \mathrm{~h}$ at $25^{\circ} \mathrm{C}, \mathrm{Et}_{3} \mathrm{~N}(1.50 \mathrm{~mL})$ was added and the yellow reaction mixture was allowed to stir for $15 \mathrm{~min}$. The solvent was removed in vacuo to yield an orange-brown oil that was partitioned between saturated aqueous $\mathrm{NaHCO}_{3}(150 \mathrm{~mL})$ and EtOAc (200 mL). The organic phase was separated and the aqueous phase was extracted with EtOAc (3 x $100 \mathrm{~mL})$. The combined organic extracts were washed with brine $(100 \mathrm{~mL})$, dried over $\mathrm{MgSO}_{4}$, and concentrated in vacuo to afford a yellow oil. The resultant oil was purified by flash chromatography (10:90 EtOAc:hexanes) to afford 28 as a colorless oil $(19.7 \mathrm{~g}, 88 \%)$ : ${ }^{1} \mathrm{H}$ NMR $\left(500 \mathrm{MHz}, \mathrm{DMSO}-d_{6}, 375 \mathrm{~K}\right) \delta 4.41(\mathrm{dd}, J=7.2,3.1,1 \mathrm{H}), 4.14(\mathrm{dd}, J=9.2,7.2,1 \mathrm{H}), 3.93(\mathrm{dd}$, $J=9.2,3.1,1 \mathrm{H}), 3.69(\mathrm{~s}, 3 \mathrm{H}), 2.28(\mathrm{td}, J=17.0,5.1,1 \mathrm{H}), 2.12(\mathrm{td}, J=17.1,5.5,1 \mathrm{H}), 1.76-1.73$ (m, 1H), 1.67-1.57 (m, 2H and m, 2H), 1.54-1.44 (m, 2H), $1.40(\mathrm{~s}, 9 \mathrm{H}), 1.20-1.08(\mathrm{~m}, 1 \mathrm{H}) ;{ }^{13} \mathrm{C}$ NMR $\left(125 \mathrm{MHz}, \mathrm{CDCl}_{3}\right.$, reported as a mixture of rotamers at $\left.298 \mathrm{~K}\right) \delta 171.9,171.5,152.3$, $151.3,96.4,95.8,80.9,80.3,66.2,65.9,59.3,59.2,52.4,52.3,34.4,33.1,32.6,31.9,28.4,28.3$, 25.0, 24.7, 23.5, 23.4, 23.4, 23.3; IR (thin film) 2973, 2933, 2864, 1760, 1708, 1384, 1366, 1203, $1178 \mathrm{~cm}^{-1}$; HRMS (ESI/methanol) $m / z$ calcd for $\mathrm{C}_{15} \mathrm{H}_{25} \mathrm{NO}_{5}(\mathrm{M}+\mathrm{Na})^{+} 322.1631$, found $322.1621 ;[\alpha]^{24}-44.1\left(c\right.$ 1.12, $\left.\mathrm{CHCl}_{3}\right)$. 


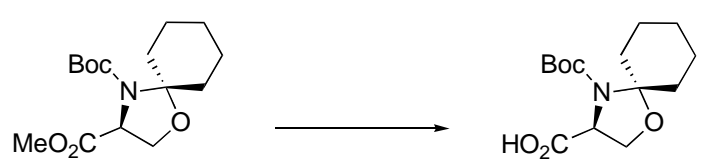

28

29

Acid 29: To a cooled $\left(0{ }^{\circ} \mathrm{C}\right)$ solution of $28(19.7 \mathrm{~g}, 65.6 \mathrm{mmol})$ in anhydrous $\mathrm{THF}(135 \mathrm{~mL})$ was added aqueous $\mathrm{LiOH}(72.0 \mathrm{~mL}, 1.0 \mathrm{~N})$ dropwise. The reaction mixture was stirred vigorously and gradually warmed to $25{ }^{\circ} \mathrm{C}$ over a period of $14 \mathrm{~h}$. To the reaction mixture was added hexanes (20 mL) and $\mathrm{H}_{2} \mathrm{O}(150 \mathrm{~mL})$. The hexanes phase was discarded, the basic aqueous phase was cooled $\left(0{ }^{\circ} \mathrm{C}\right)$, acidified to $\mathrm{pH} 2$ with $1.0 \mathrm{~N} \mathrm{HCl}$, and extracted with EtOAc $(3 \times 100 \mathrm{~mL})$. The combined organic phases were dried $\left(\mathrm{MgSO}_{4}\right)$ and concentrated in vacuo to afford a thick colorless oil. The resultant oil was dried under reduced pressure $(0.5 \mathrm{mmHg})$ for $24 \mathrm{~h}$ to provide 29 as a white solid (17.3 g, 92\%): $\mathrm{mp}=104-107{ }^{\circ} \mathrm{C} ;{ }^{1} \mathrm{H}$ NMR (500 MHz, DMSO- $\left.d_{6}, 375 \mathrm{~K}\right) \delta$ $4.32(\mathrm{dd}, J=7.2,3.2,1 \mathrm{H}), 4.12(\mathrm{dd}, J=9.0,7.2,1 \mathrm{H}), 3.93(\mathrm{dd}, J=9.0,3.2,1 \mathrm{H}), 2.29-2.24(\mathrm{~m}$, 1H), 2.17-2.11 (m, 1H), 1.78-1.76 (m, 1H), 1.64-1.58 (m, 1H), 1.52-1.44 (m, 1H), $1.42(\mathrm{~s}, 9 \mathrm{H})$, $1.98-1.10(\mathrm{~m}, 1 \mathrm{H}) ;{ }^{13} \mathrm{C} \mathrm{NMR}\left(125 \mathrm{MHz}, \mathrm{CDCl}_{3}\right.$, reported as a mixture of rotamers at $\left.298 \mathrm{~K}\right) \delta$ 177.4, 175.6, 153.2, 151.3, 96.6, 96.2, 81.8, 80.7, 66.1, 65.4, 59.1, 59.1, 34.5, 33.2, 32.1, 31.8, 28.4, 28.3, 25.0, 24.6, 23.4, 23.3; IR (KBr) 3164, 2975, 2934, 2864, 1731, 1705, 1394, 1367 $\mathrm{cm}^{-1}$; HRMS (ESI/methanol) $m / z$ calcd for $\mathrm{C}_{14} \mathrm{H}_{23} \mathrm{NO}_{5}(\mathrm{M}+\mathrm{Na})^{+}$308.1474, found 308.1483; $[\alpha]^{26}-60.7\left(c 1.28, \mathrm{CHCl}_{3}\right)$.

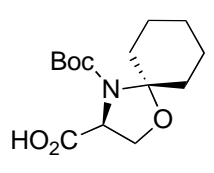

29

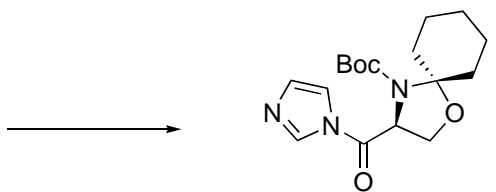

26

$N$-Acylimidazole 26: To a cooled $\left(0^{\circ} \mathrm{C}\right)$ solution of $29(16.9 \mathrm{~g}, 59.2 \mathrm{mmol})$ in $\mathrm{THF}(120 \mathrm{~mL})$ was added carbonyl diimidazole $(14.4 \mathrm{~g}, 86.6 \mathrm{mmol})$ in one portion. After $2 \mathrm{~h}$ at $0{ }^{\circ} \mathrm{C}$, the 
reaction was quenched by the addition of water $(125 \mathrm{~mL})$, followed by the addition of $\mathrm{Et}_{2} \mathrm{O}$ (125 $\mathrm{mL}$ ). The reaction mixture was vigorously stirred for $15 \mathrm{~min}$ and the organic phase was separated. The aqueous phase was extracted with $\mathrm{Et}_{2} \mathrm{O}(3 \times 150 \mathrm{~mL})$. The combined organic extracts were washed with $\mathrm{H}_{2} \mathrm{O}(2 \times 150 \mathrm{~mL})$, dried over $\mathrm{MgSO}_{4}$, and concentrated in vacuo to yield 26 as a white solid $(19.5 \mathrm{~g}, 98 \%)$. The solid was used without further purification: $\mathrm{mp}=$ $125-127{ }^{\circ} \mathrm{C} ;{ }^{1} \mathrm{H}$ NMR $\left(500 \mathrm{MHz}\right.$, DMSO- $\left.d_{6}, 375 \mathrm{~K}\right) \delta 8.44$ (br s, 1H), 7.73 (app t, $\left.J=1.4,1 \mathrm{H}\right)$, $7.11(\mathrm{dd}, J=1.7,0.70,1 \mathrm{H}), 5.35(\mathrm{dd}, J=7.4,3.5,1 \mathrm{H}), 4.33(\mathrm{dd}, J=9.5,7.4,1 \mathrm{H}), 4.03(\mathrm{dd}, J=$ $9.5,3.5,1 \mathrm{H}), 2.31(\mathrm{td}, J=13.5,4.4,1 \mathrm{H}), 2.18(\mathrm{td}, J=13.4,4.4,1 \mathrm{H}), 1.91-1.88(\mathrm{~m}, 1 \mathrm{H}), 1.70$ $1.62(\mathrm{~m}, 2 \mathrm{H}$ and $\mathrm{m}, 2 \mathrm{H}), 1.55-1.46(\mathrm{~m}, 2 \mathrm{H}), 1.33(\mathrm{~s}, 9 \mathrm{H}), 1.23-1.13(\mathrm{~m}, 1 \mathrm{H}) ;{ }^{13} \mathrm{C}$ NMR $(125$ $\mathrm{MHz}, \mathrm{CDCl}_{3}$, reported as a mixture of rotamers at $\left.298 \mathrm{~K}\right) \delta 167.5,167.0,152.3,150.7,136.1$, 136.0, 131.6, 131.3, 116.1, 116.0, 97.3, 96.6, 81.7, 81.4, 66.0, 65.5, 59.8, 59.5, 34.2, 34.2, 32.8, 32.3, 28.4, 28.0, 25.0, 24.6, 23.5, 23.4, 23.4, 23.2; IR (KBr) 3124, 2974, 2934, 1750, 1710, 1696, 1394, 1377, $1366 \mathrm{~cm}^{-1}$; HRMS (ESI/methanol) $\mathrm{m} / z$ calcd for $\mathrm{C}_{17} \mathrm{H}_{25} \mathrm{~N}_{3} \mathrm{O}_{4}(\mathrm{M}+\mathrm{Na})^{+} 358.1743$, found $358.1735 ;[\alpha]^{26}-39.6\left(c 1.29, \mathrm{CHCl}_{3}\right)$.

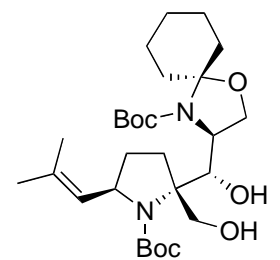

33

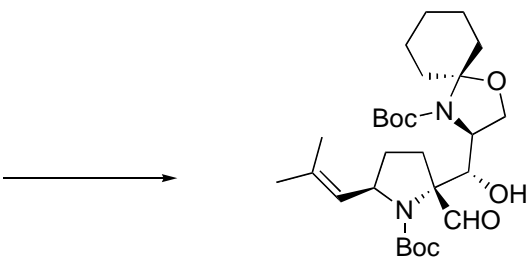

B

$\beta$-Hydroxy Aldehyde B: To a stirred solution of diol $\mathbf{3 3}(0.401 \mathrm{~g}, 0.766 \mathrm{mmol})$ in $\mathrm{CH}_{2} \mathrm{Cl}_{2}(5$ $\mathrm{mL})$ was added TEMPO $(0.017 \mathrm{~g}, 0.188 \mathrm{mmol})$ and BAIB $(0.525 \mathrm{~g}, 1.60 \mathrm{mmol})$. After $24 \mathrm{~h}$, TLC analysis (30:70 EtOAc:hexanes) showed the persistence to starting material. Additional TEMPO $(0.020 \mathrm{~g}, 0.221 \mathrm{mmol})$ and BAIB $(0.106 \mathrm{~g}, 0.329 \mathrm{mmol})$ were added and the reaction mixture was stirred for another $24 \mathrm{~h}$. The reaction mixture was quenched by the addition of 
saturated aqueous $\mathrm{Na}_{2} \mathrm{~S}_{2} \mathrm{O}_{3}(10 \mathrm{~mL})$ and stirred for $15 \mathrm{~min}$, and followed by the addition of $\mathrm{H}_{2} \mathrm{O}$ (20 mL). The aqueous layer was extracted with $\mathrm{CH}_{2} \mathrm{Cl}_{2}(3 \times 30 \mathrm{~mL})$ and the combined organic extracts were washed with saturated aqueous $\mathrm{NaHCO}_{3}(40 \mathrm{~mL})$, dried over $\mathrm{MgSO}_{4}$, and concentrated in vacuo to give a white solid. The solid was purified by flash chromatography (20:80 EtOAc:hexanes) to yield $\beta$-hydroxy aldehyde B as a white foam $(0.306 \mathrm{~g}, 77 \%):{ }^{1} \mathrm{H}$ NMR (500 MHz, DMSO- $\left.d_{6}, 375 \mathrm{~K}\right) \delta 9.72(\mathrm{~s}, 1 \mathrm{H}), 5.16$ (app dsep, $\left.J=8.9,1.4,1 \mathrm{H}\right), 5.00$ (br s, 1H), $4.55(\mathrm{~d}, J=1.6,1 \mathrm{H}), 4.50(\mathrm{td}, J=8.4,3.1,1 \mathrm{H}), 4.08(\mathrm{dd}, J=8.8,2.8,1 \mathrm{H}), 4.01(\mathrm{dt}, J=6.7,2.7$, $1 \mathrm{H}), 3.86(\mathrm{dd}, J=8.8,6.7,1 \mathrm{H}), 2.21-2.10(\mathrm{~m}, 3 \mathrm{H}), 2.05-2.01(\mathrm{~m}, 2 \mathrm{H}), 1.81-1.76(\mathrm{~m}, 1 \mathrm{H}), 1.68$ $(\mathrm{d}, J=1.2,3 \mathrm{H}), 1.64(\mathrm{~d}, J=1.1,3 \mathrm{H}), 1.62-1.57(\mathrm{~m}, 3 \mathrm{H}), 1.54-1.48(\mathrm{~m}, 3 \mathrm{H}), 1.47-1.45(\mathrm{~m}, 1 \mathrm{H}$ and s, 9H), $1.38(\mathrm{~s}, 9 \mathrm{H}), 1.15-1.08(\mathrm{~m}, 1 \mathrm{H}) ;{ }^{13} \mathrm{C} \mathrm{NMR}\left(125 \mathrm{MHz}, \mathrm{CDCl}_{3}\right.$, only major rotamer reported at $298 \mathrm{~K}) \delta 198.1,157.0,152.8,131.7,126.0,94.9,94.6,81.4,80.3,76.5,74.2,62.4$, 59.4, 58.1, 34.5, 32.4, 30.3, 28.4, 28.3, 25.6, 25.1, 23.6, 23.5, 18.0; HRMS (ESI/methanol) $\mathrm{m} / \mathrm{z}$ calcd for $\mathrm{C}_{28} \mathrm{H}_{46} \mathrm{~N}_{2} \mathrm{O}_{7}(\mathrm{M}+\mathrm{Na})^{+}$545.3203, found 545.3201; $[\alpha]^{27}-67.7\left(c 0.51, \mathrm{CHCl}_{3}\right)$.

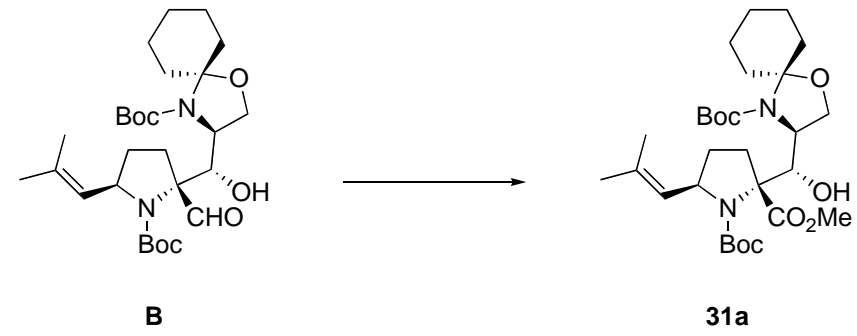

$\beta$-Hydroxy Ester 31a: To a vigorously stirred solution of $\beta$-hydroxy aldehyde $\mathbf{B}$ (0.306 g, $0.586 \mathrm{mmol})$ in a mixture of $\mathrm{THF} / \mathrm{t}-\mathrm{BuOH} / \mathrm{H}_{2} \mathrm{O}(5 \mathrm{~mL}, 3: 3: 1$ mixture $)$ was added 2-methyl-2butene $(1.30 \mathrm{~mL}, 12.3 \mathrm{mmol}), \mathrm{NaH}_{2} \mathrm{PO}_{4} \cdot \mathrm{H}_{2} \mathrm{O}(0.336 \mathrm{~g}, 2.44 \mathrm{mmol})$, and finally $\mathrm{NaClO}_{2}(0.093 \mathrm{~g}$, $1.06 \mathrm{mmol}$ ). After $5 \mathrm{~h}$, the consumption of starting material was detected by TLC analysis (40:60 EtOAc:hexanes). The reaction mixture was diluted by the addition of $\mathrm{H}_{2} \mathrm{O}(20 \mathrm{~mL})$ and extracted 
with EtOAc $(3 \times 30 \mathrm{~mL})$. The combined organic extracts were dried over $\mathrm{Na}_{2} \mathrm{SO}_{4}$ and concentrated in vacuo.

Under a constant atmosphere of $\mathrm{N}_{2}(\mathrm{~g})$ the acid was immediately diluted in $\mathrm{MeOH} / \mathrm{EtOAc}$ (4 mL, 3:1 mixture), cooled $\left(0^{\circ} \mathrm{C}\right)$, and trimethylsilyl diazomethane $(0.700 \mathrm{~mL}, 1.40 \mathrm{mmol})$ was added. The resulting yellow mixture was allowed to stir for $5 \mathrm{~min}$ before $\mathrm{AcOH}(50 \mu \mathrm{L})$ was added. After the evolution of $\mathrm{N}_{2}(\mathrm{~g})$ ceased, saturated aqueous $\mathrm{NaHCO}_{3}(10 \mathrm{~mL})$ was added, the organic layer was separated, aqueous layer extracted with EtOAc $(3 \times 20 \mathrm{~mL})$, dried over $\mathrm{MgSO}_{4}$, and concentrated to give a white foam. The foam was purified by flash chromatography (10:90 EtOAc:hexanes) to yield $\beta$-hydroxy ester 31a as a white foam $(0.313 \mathrm{~g}, 97 \%)$.

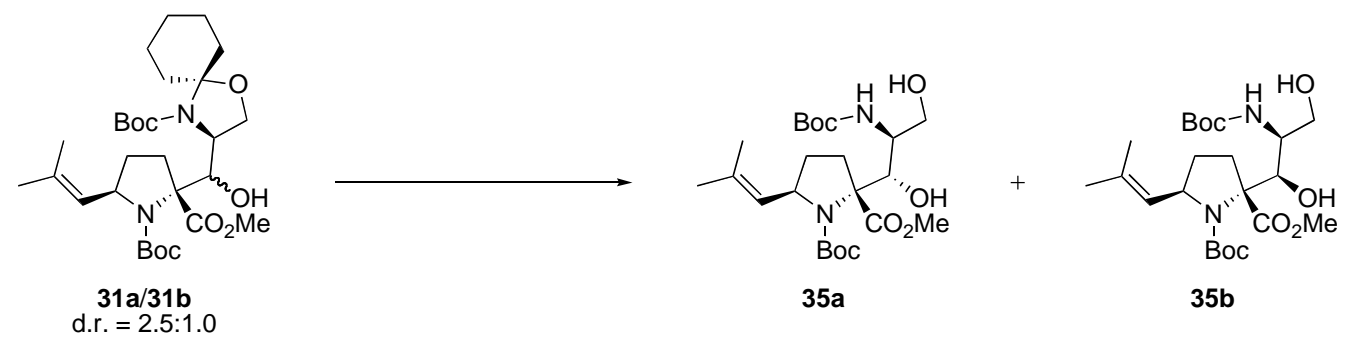

Amino Diols 35: To a mixture of 31a and 31b (0.325 g, $0.588 \mathrm{mmol}$, d.r. $(31 \mathrm{a}: 31 \mathbf{b})=2.5: 1.0)$ was added $80 \%$ aqueous $\mathrm{AcOH}(10 \mathrm{~mL})$ and stirred vigorously. After $24 \mathrm{~h}$ at room temperature, TLC analysis (50:50 EtOAc:hexanes) of the reaction mixture showed presence of some starting material. Additional $80 \%$ aqueous $\mathrm{AcOH}(5 \mathrm{~mL})$ and THF (4 mL) were added to the suspension. After an additional $48 \mathrm{~h}$, consumption of starting material was observed by TLC analysis (50:50 EtOAc:hexanes). The reaction mixture was added slowly to a cooled $\left(0^{\circ} \mathrm{C}\right)$ and vigorously stirred biphasic mixture of EtOAc $(40 \mathrm{~mL})$ and saturated $\mathrm{NaHCO}_{3}(60 \mathrm{~mL})$. Once $\mathrm{CO}_{2}(\mathrm{~g})$ evolution ceased, the biphasic mixture was warmed to room temperature and stirred for $1 \mathrm{~h}$. The organic layer was separated and the aqueous layer was extracted with EtOAc $(2 \times 50 \mathrm{~mL})$. The combined organic extracts were washed with brine $(30 \mathrm{~mL})$, dried over $\mathrm{MgSO}_{4}$, and concentrated 
in vacuo to give a white foam. The foam was purified by flash chromatography (gradient elution 20:80 - 30:70 - 40:60 - 60:40 EtOAc:hexanes) to yield diols 35a (0.182 g) and 35b (0.071 g) as white foams $(0.253 \mathrm{~g}, 91 \%)$ :

35a: ${ }^{1} \mathrm{H}$ NMR $\left(500 \mathrm{MHz}\right.$, DMSO- $\left.d_{6}, 385 \mathrm{~K}\right) \delta 5.81(\mathrm{~d}, J=7.7,1 \mathrm{H}), 5.25(\mathrm{~d}$ sep $, J=8.7,1.4$, $1 \mathrm{H}), 5.15(\mathrm{~d}, J=8.7,1 \mathrm{H}), 4.53(\mathrm{td}, J=8.1,4.8,1 \mathrm{H}), 4.30(\mathrm{dd}, J=8.8,7.1,1 \mathrm{H}), 4.00($ app t,$J=$ $5.4,1 \mathrm{H}), 3.67(\mathrm{~s}, 3 \mathrm{H}), 3.63-3.53(\mathrm{~m}, 2 \mathrm{H}$ and dd, $J=6.7,5.6,1 \mathrm{H}), 2.32-2.27(\mathrm{~m}, 1 \mathrm{H}), 2.20-2.08$ $(\mathrm{m}, 2 \mathrm{H}), 1.68(\mathrm{~d}, J=1.2,3 \mathrm{H}), 1.63(\mathrm{~d}, J=1.2,3 \mathrm{H}), 1.45-1.40(\mathrm{~m}, 1 \mathrm{H}$ and s, $9 \mathrm{H}), 1.39(\mathrm{~s}, 9 \mathrm{H})$; ${ }^{13} \mathrm{C}$ NMR $\left(125 \mathrm{MHz}, \mathrm{CDCl}_{3}\right) \delta 172.9,157.2,155.7,131.2,126.4,81.5,79.7,77.9,74.7,63.5$, 59.9, 52.8, 52.4, 34.0, 30.1, 28.4, 28.3, 25.6, 17.9; IR (thin film) 3428, 3301, 2976, 2931, 2889 , 1750, 1712, 1691, 1665, 1455, 1396, 1366, $1163 \mathrm{~cm}^{-1}$; HRMS (ESI/methanol) $\mathrm{m} / \mathrm{z}$ calcd for $\mathrm{C}_{23} \mathrm{H}_{40} \mathrm{~N}_{2} \mathrm{O}_{8}(\mathrm{M}+\mathrm{H})^{+}$473.2863, found 473.2852; $[\alpha]^{24}{ }_{\mathrm{D}}-24.4\left(c 0.25, \mathrm{CHCl}_{3}\right)$.

35b: ${ }^{1} \mathrm{H}$ NMR (500 MHz, DMSO- $\left.d_{6}, 385 \mathrm{~K}\right) \delta 5.39$ (d sep, $\left.J=8.8,1.4,1 \mathrm{H}\right), 5.29$ (br s, $\left.1 \mathrm{H}\right)$, $4.63(\mathrm{~s}, 1 \mathrm{H}), 4.57(\mathrm{td}, J=8.3,4.0,1 \mathrm{H}), 4.51(\mathrm{br} \mathrm{s}, 1 \mathrm{H}), 3.67(\mathrm{~s}, 3 \mathrm{H}), 3.61-3.55(\mathrm{~m}, 1 \mathrm{H}), 3.40$ (dd, $J=10.3,7.0,1 \mathrm{H}), 3.35(\mathrm{dd}, J=10.3,5.9,1 \mathrm{H}), 2.47(\mathrm{ddd}, J=13.3,8.2,5.0,1 \mathrm{H}), 2.15-2.08$ $(\mathrm{m}, 1 \mathrm{H}), 1.97(\mathrm{dt}, J=13.3,8.5,1 \mathrm{H}), 1.69(\mathrm{~d}, J=1.1,3 \mathrm{H}), 1.64(\mathrm{~d}, J=1.2,3 \mathrm{H}), 1.53-1.47(\mathrm{~m}$, 1H), $1.43(\mathrm{~s}, 9 \mathrm{H}), 1.36(\mathrm{~s}, 9 \mathrm{H}) ;{ }^{13} \mathrm{C} \mathrm{NMR}\left(125 \mathrm{MHz}, \mathrm{CDCl}_{3}\right.$, only major rotamer reported at 298 K) $\delta 176.6,156.4,154.6,131.2,126.5,80.4,79.6,71.6,69.9,66.5,58.5,52.6,50.7,30.8,29.5$, 28.4, 28.3, 25.8, 18.0; IR (thin film) 3504, 3447, 2976, 2932, 2884, 1712, 1693, 1497, 1455, 1391, 1366, 1254, $1164 \mathrm{~cm}^{-1}$; HRMS (ESI/methanol) $\mathrm{m} / z$ calcd for $\mathrm{C}_{23} \mathrm{H}_{40} \mathrm{~N}_{2} \mathrm{O}_{8}(\mathrm{M}+\mathrm{H})^{+}$ 473.2863, found 473.2843; $[\alpha]^{24}+56.0\left(c 0.05, \mathrm{CHCl}_{3}\right)$. 


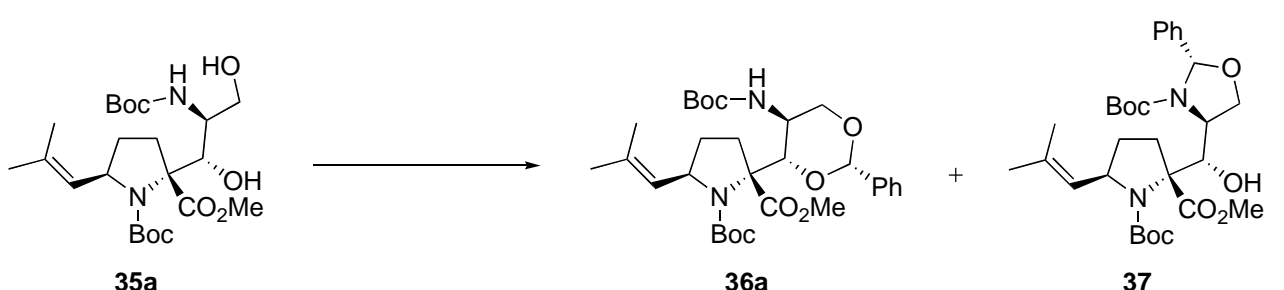

Benzylidene Acetals 36a/37: To a solution of 35a $(0.057 \mathrm{~g}, 0.120 \mathrm{mmol})$ in $\mathrm{CH}_{2} \mathrm{Cl}_{2}(5.0 \mathrm{~mL})$ was added $4 \AA$ molecular sieves, benzylidene dimethylacetal $(30.0 \mu \mathrm{L}, 0.200 \mathrm{mmol})$, and $(S)-(+)$-camphorsulfonic acid $(0.005 \mathrm{~g}, 0.022 \mathrm{mmol})$. The reaction mixture was stirred vigorously for $24 \mathrm{~h}$. The reaction mixture was filtered over a pad of Celite and washed with $\mathrm{CH}_{2} \mathrm{Cl}_{2}(3 \times 20$ $\mathrm{mL})$. The combined organic layer was washed with $\mathrm{NaHCO}_{3}(15 \mathrm{~mL})$, brine $(10 \mathrm{~mL})$, dried over $\mathrm{Na}_{2} \mathrm{SO}_{4}$, and concentrated in vacuo to provide thick yellow oil. The oil was purified by flash chromatography (gradient elution 10:80 - 20:80 EtOAc:hexanes) to yield 36a and 37 (0.054 g, $80 \%$, ratio of $\mathbf{3 6 a}: \mathbf{3 7}=2: 1)$. Acetal 36a was isolated as a clear oil $(0.037 \mathrm{~g})$ and $\mathbf{3 7}$ was isolated as a white solid $(0.017 \mathrm{~g})$. Acetal $\mathbf{3 5}$ was recrystallized from EtOAc/hexanes to yield needle-like crystals suitable for X-ray (see Section III for X-ray data).

36a: ${ }^{1} \mathrm{H}$ NMR (500 MHz, DMSO- $\left.d_{6}, 375 \mathrm{~K}\right) \delta$ 7.45-7.40 (m, 2H), 7.37-7.33 (m, 3H), 6.07 (d, $J$ $=7.0,1 \mathrm{H}), 5.42(\mathrm{~s}, 1 \mathrm{H}), 5.19(\mathrm{~d} \operatorname{sep}, J=8.9,1.4,1 \mathrm{H}), 4.79(\mathrm{~d}, J=9.6,1 \mathrm{H}), 4.40(\mathrm{td}, J=8.2,4.8$, $1 \mathrm{H}), 4.11(\mathrm{dd}, J=9.9,4.0,1 \mathrm{H}), 3.69(\mathrm{~s}, 3 \mathrm{H}$ and $\mathrm{m}, 2 \mathrm{H}), 2.24-2.20(\mathrm{~m}, 1 \mathrm{H}$ and $\mathrm{m}, 1 \mathrm{H}), 2.19$ $2.10(\mathrm{~m}, 1 \mathrm{H}), 1.68(\mathrm{~d}, J=1.0,3 \mathrm{H}), 1.61(\mathrm{~d}, J=1.0,3 \mathrm{H}$ and $\mathrm{m}, 1 \mathrm{H}), 1.41(\mathrm{~s}, 9 \mathrm{H}), 1.29(\mathrm{~s}, 9 \mathrm{H})$ ${ }^{13} \mathrm{C}$ NMR $\left(125 \mathrm{MHz}, \mathrm{CDCl}_{3}\right.$, only major rotamer reported at $\left.298 \mathrm{~K}\right) \delta 175.4,155.3,154.4,138.1$, $130.9,128.7,128.0,127.0,126.0,101.6,79.6,78.3,76.9,70.6,69.9,57.3,53.0,46.5,31.8,30.3$, 28.4, 28.3, 25.7, 18.0; IR (thin film) 3375, 2975, 2930, 2873, 1734, 1709, 1689, 1508, 1452, 1390, 1365, 1298, 1241, $1164 \mathrm{~cm}^{-1}$; HRMS (ESI/methanol) $m / z$ calcd for $\mathrm{C}_{30} \mathrm{H}_{44} \mathrm{~N}_{2} \mathrm{O}_{8}(\mathrm{M}+\mathrm{Na})^{+}$ 583.2996, found 583.2999; $[\alpha]^{22}+24.2\left(c 0.36, \mathrm{CHCl}_{3}\right)$. 
37: ${ }^{1} \mathrm{H}$ NMR (500 MHz, DMSO- $\left.d_{6}, 385 \mathrm{~K}\right) \delta$ 7.38-7.31 (m, 5H), 5.81 (s, 1H), 5.35 (d sep, $J=$ $8.9,1.4,1 \mathrm{H}), 4.78(\mathrm{br} \mathrm{s}, 1 \mathrm{H}), 4.62(\mathrm{td}, J=7.9,2.8,1 \mathrm{H}), 4.37(\mathrm{ddd}, J=7.0,4.2,1.6,1 \mathrm{H}), 4.17$ (dd, $J=8.7,4.1,1 \mathrm{H}), 4.11(\mathrm{dd}, J=8.7,7.0,1 \mathrm{H}), 3.72(\mathrm{~s}, 3 \mathrm{H}), 2.39-2.35(\mathrm{~m}, 1 \mathrm{H}), 2.24-2.19(\mathrm{~m}$, $2 \mathrm{H}), 1.70(\mathrm{~d}, J=1.2,3 \mathrm{H}), 1.66(\mathrm{~d}, J=1.2,3 \mathrm{H}), 1.55-1.51(\mathrm{~m}, 1 \mathrm{H}), 1.41(\mathrm{~s}, 9 \mathrm{H}), 1.16(\mathrm{~s}, 9 \mathrm{H})$; ${ }^{13} \mathrm{C}$ NMR (125 MHz, $\mathrm{CDCl}_{3}$, only major rotamer reported at $298 \mathrm{~K}$ ) $\delta 173.0,157.3,152.3,140.6$, 131.6, 128.6, 128.3, 126.7, 125.7, 90.1, 81.5, 80.4, 75.0, 73.3, 64.6, 59.9, 57.6, 52.8, 34.5, 31.1, 29.8, 28.4, 28.0, 22.4, 14.1; IR (thin film) 3312, 2976, 2973, 1749, 1692, 1665, 1458, 1391, 1366, 1250, $1159 \mathrm{~cm}^{-1}$ : HRMS (ESI/methanol) $m / z$ calcd for $\mathrm{C}_{30} \mathrm{H}_{44} \mathrm{~N}_{2} \mathrm{O}_{8}(\mathrm{M}+\mathrm{H})^{+} 561.3176$, found $561.3159 ;[\alpha]^{22}-74.6\left(c 0.25, \mathrm{CHCl}_{3}\right)$.

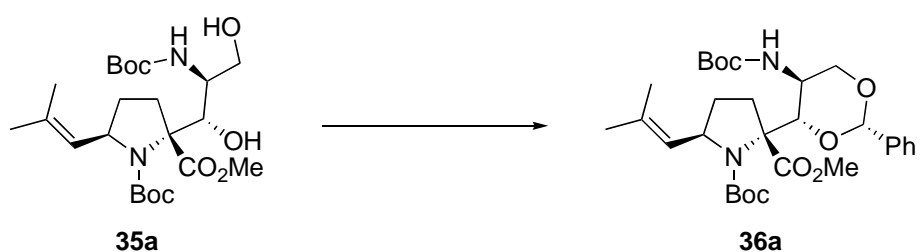

Benzylidine Acetal 36a: To a solution of 35a $(0.052 \mathrm{~g}, 0.110 \mathrm{mmol})$ in $\mathrm{CH}_{2} \mathrm{Cl}_{2}(2.0 \mathrm{~mL})$ was added benzylidene dimethylacetal $(50.0 \mu \mathrm{L}, 0.330 \mathrm{mmol})$ and $p$-TsOH $(0.005 \mathrm{~g}, 0.03 \mathrm{mmol})$. The reaction mixture was stirred for $24 \mathrm{~h} . \mathrm{NaHCO}_{3}(20 \mathrm{~mL})$ was added and the reaction mixture was stirred vigorously for $10 \mathrm{~min}$. The organic phase was separated and the aqueous layer was extracted with $\mathrm{CH}_{2} \mathrm{Cl}_{2}(3 \times 20 \mathrm{~mL})$. The combined organic extracts were washed with brine (10 $\mathrm{mL}$ ), dried over $\mathrm{Na}_{2} \mathrm{SO}_{4}$, and concentrated in vacuo to provide thick a yellow oil. The oil was purified by flash chromatography (10:90 EtOAc:hexanes) to yield 36a as a clear oil (0.048 g, 77\%). (For characterization details of 36a see above) 


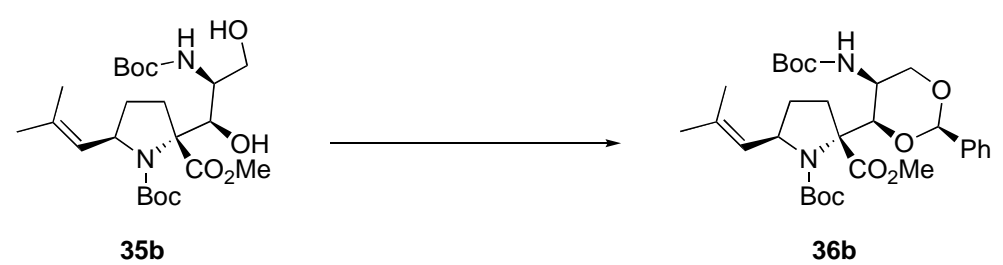

Benzylidine Acetal 36b: To a solution of $\mathbf{3 5 b}(0.044 \mathrm{~g}, 0.093 \mathrm{mmol})$ in $\mathrm{CH}_{2} \mathrm{Cl}_{2}(2.0 \mathrm{~mL})$ was added benzylidene dimethylacetal $(50.0 \mu \mathrm{L}, 0.330 \mathrm{mmol})$ and $p$-TsOH $(0.004 \mathrm{~g}, 0.023 \mathrm{mmol})$. The reaction mixture was stirred for $24 \mathrm{~h} . \mathrm{NaHCO}_{3}(10 \mathrm{~mL})$ was added and the reaction mixture was stirred vigorously for $10 \mathrm{~min}$. The organic phase was separated and the aqueous layer was extracted with $\mathrm{CH}_{2} \mathrm{Cl}_{2}(3 \times 20 \mathrm{~mL})$. The combined organic extracts were washed with brine (20 $\mathrm{mL}$ ), dried over $\mathrm{Na}_{2} \mathrm{SO}_{4}$, and concentrated in vacuo to provide thick a yellow oil. The oil was purified by flash chromatography (10:90 EtOAc:hexanes) to yield $\mathbf{3 6} \mathbf{b}$ as a clear oil (0.025 g, 48\%): ${ }^{1} \mathrm{H}$ NMR (500 MHz, DMSO- $\left.d_{6}, 375 \mathrm{~K}\right) \delta$ 7.55-7.52 (m, 2H), 7.40-7.34 (m, 3H), $6.01(\mathrm{~d}$, $J=9.5,1 \mathrm{H}), 5.68(\mathrm{~s}, 1 \mathrm{H}), 5.44(\mathrm{~d} \mathrm{sep}, J=8.9,1.4,1 \mathrm{H}), 4.94(\mathrm{~d}, J=1.5,1 \mathrm{H}), 4.51(\mathrm{td}, J=8.6$ 4.1, 1H), $4.10(\mathrm{dd}, J=11.4,1.8,1 \mathrm{H}), 3.92(\mathrm{dd}, J=11.4,1.9,1 \mathrm{H}), 3.68(\mathrm{~s}, 3 \mathrm{H}), 3.62(\operatorname{app} \mathrm{dd}, J=$ $10.0,1.7,1 \mathrm{H}), 2.71(\mathrm{ddd}, J=13.9,8.9,5.0,1 \mathrm{H}), 2.31$ (dddd, $J=12.3,8.6,8.5,8.4,1 \mathrm{H}), 1.95(\mathrm{dt}$, $J=14.0,8.7,1 \mathrm{H}), 1.69(\mathrm{~d}, J=1.1,3 \mathrm{H}), 1.61(\mathrm{~d}, J=1.2,3 \mathrm{H}), 1.59-1.52(\mathrm{~m}, 1 \mathrm{H}), 1.47(\mathrm{~s}, 9 \mathrm{H})$, $1.38(\mathrm{~s}, 9 \mathrm{H}) ;{ }^{13} \mathrm{C} \mathrm{NMR}\left(125 \mathrm{MHz}, \mathrm{CDCl}_{3}\right.$, only major rotamer reported at $\left.298 \mathrm{~K}\right) \delta 175.1,155.0$, $154.9,138.2,130.1,128.9,128.3,127.6,125.9,101.6,80.0,79.4,77.3,73.5,70.3,58.6,52.6$, 45.4, 31.2, 30.1, 28.5, 28.3, 25.7, 17.8; IR (thin film) 3450, 3363, 3066, 3008, 2975, 2930, 2868 , $1744,1715,1684,1495,1455,1392,1366,1239,1162 \mathrm{~cm}^{-1} ;$ HRMS (ESI/methanol) $\mathrm{m} / \mathrm{z}$ calcd for $\mathrm{C}_{30} \mathrm{H}_{44} \mathrm{~N}_{2} \mathrm{O}_{8}(\mathrm{M}+\mathrm{Na})^{+}$583.2996, found 583.2997; $[\alpha]^{22}{ }_{\mathrm{D}}+63.0\left(c 0.25, \mathrm{CHCl}_{3}\right)$. 


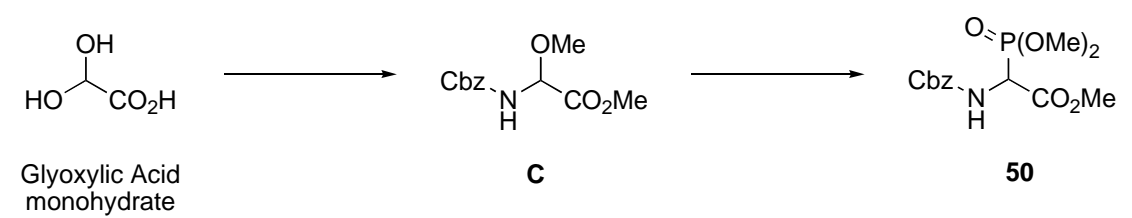

Aminal C: Aminal $\mathbf{C}$ was synthesized using the procedure described by Ben-Ishai. ${ }^{8}$ Glyoxylic acid monohydrate $(27.9 \mathrm{~g}, 0.303 \mathrm{~mol})$ and benzyl carbamate $(41.3 \mathrm{~g}, 0.273 \mathrm{~mol})$ were diluted with $\mathrm{Et}_{2} \mathrm{O}(250 \mathrm{~mL})$ and stirred at room temperature. After $10 \mathrm{~h}$, the desired hemi-aminal crystallized out of solution and the reaction mixture was concentrated and dried $(0.50 \mathrm{mmHg}$ for $2 \mathrm{hr}$ ) to yield hemi-aminal. To the hemi-aminal was added $\mathrm{MeOH}(700 \mathrm{~mL})$ and concentrated $\mathrm{H}_{2} \mathrm{SO}_{4}(8.20 \mathrm{~mL}, 0.148 \mathrm{~mol}, 54 \mathrm{~mol} \%)$. The homogenous mixture was stirred at room temperature for 5 days. The reaction mixture was poured over a cooled $\left(0{ }^{\circ} \mathrm{C}\right)$ solution of saturated $\mathrm{NaHCO}_{3}(1.00 \mathrm{~L})$. The product immediately precipitated out of the aqueous layer and EtOAc $(1.00 \mathrm{~L})$ was added to dissolve the precipitates. The organic layer was separated and the aqueous layer extracted with EtOAc $(4 \times 500 \mathrm{~mL})$. The combined organic extracts were washed with brine $(700 \mathrm{~mL})$, dried over $\mathrm{MgSO}_{4}$, and concentrated in vacuo to give a white solid. To the oil was added petroleum ether $(250 \mathrm{~mL})$ and the reaction mixture was stirred for $30 \mathrm{~min}$, at which point the product crashed out. The precipitates were filtered and washed with cooled $(0$ $\left.{ }^{\circ} \mathrm{C}\right)$ petroleum ether $(4 \times 50 \mathrm{~mL})$ and the filtrate was concentrated to give an oil. The oil was once again stirred with petroleum ether as above. The solids were combined and dried $(0.5 \mathrm{mmHg})$ to yield the aminal $\mathbf{C}(57.5 \mathrm{~g}, 64 \%): \mathrm{mp}=76-79{ }^{\circ} \mathrm{C} ;{ }^{1} \mathrm{H}$ NMR $\left(500 \mathrm{MHz}, \mathrm{CDCl}_{3}\right) \delta 7.38-7.32(\mathrm{~m}$, 5H), $5.84(\mathrm{br} \mathrm{s}, 1 \mathrm{H}), 5.36(\mathrm{~d}, J=9.4,1 \mathrm{H}), 5.15(\mathrm{br} \mathrm{s}, 2 \mathrm{H}), 3.81(\mathrm{~s}, 3 \mathrm{H}), 3.47(\mathrm{br} \mathrm{s}, 3 \mathrm{H}) ;{ }^{13} \mathrm{C} \mathrm{NMR}$ $\left(125 \mathrm{MHz}, \mathrm{CDCl}_{3}\right) \delta 168.1,155.7,135.8,128.7,128.5,128.3,80.7,67.5,56.4,53.0 ; \mathrm{IR}(\mathrm{KBr})$ $3310,3035,2945,2970,2946,2905,2846,1755,1688,1534,1456,1439,1362,1264,1229$, $1198 \mathrm{~cm}^{-1}$; HRMS (ESI/methanol) $m / z$ calcd for $\mathrm{C}_{12} \mathrm{H}_{15} \mathrm{NO}_{5}(\mathrm{M}+\mathrm{Na})^{+}$276.0840, found 276.0846. 
Phosphonate 50: Phosphonate 50 was synthesized using the procedure described by Schmidt. ${ }^{9}$ To a heated $\left(80{ }^{\circ} \mathrm{C}\right)$ solution of aminal $\mathbf{C}(11.1 \mathrm{~g}, 43.8 \mathrm{mmol})$ in toluene $(45 \mathrm{~mL})$ was slowly added $\mathrm{PCl}_{3}(4.20 \mathrm{~mL}, 48.8 \mathrm{mmol})$. [Caution: Evolution of $\mathrm{HCl}$ observed. Slow and dropwise addition of $\mathrm{PCl}_{3}$ was necessary]. After complete addition of phosphorus trichloride, the reaction mixture was heated to $100{ }^{\circ} \mathrm{C}-110{ }^{\circ} \mathrm{C}$. The consumption of starting material was monitored by TLC (40:60 EtOAc:hexanes). After consumption of starting material (2-3 h), $\mathrm{P}(\mathrm{OMe})_{3}(5.80 \mathrm{~mL}$, $49.2 \mathrm{mmol}$ ) was added. [Caution: Reaction generates $\mathrm{CH}_{3} \mathrm{Cl}$. Reaction should be performed in a well-ventilated hood and slow and dropwise addition of trimethyl phosphite was necessary]. After $2 \mathrm{~h}$, the reaction mixture was cooled to room temperature and the resulting murky orange solution was concentrated in vacuo to afford an orange oil. The oil was partitioned between EtOAc $(150 \mathrm{~mL})$ and saturated aqueous $\mathrm{NaHCO}_{3}(100 \mathrm{~mL})$. The organic layer was separated and the aqueous layer extracted with EtOAc $(5 \times 100 \mathrm{~mL})$. The combined organic extracts were washed with $\mathrm{H}_{2} \mathrm{O}(2 \times 100 \mathrm{~mL})$, brine $(250 \mathrm{~mL})$, dried over $\mathrm{MgSO}_{4}$, and concentrated to give an oil. The oil was triturated with hexanes $(50 \mathrm{~mL})$ and stirred vigorously for $1 \mathrm{~h}$ to allow precipitation of the product. The solids were filtered, washed with cooled $\left(0{ }^{\circ} \mathrm{C}\right)$ hexanes $(4 \mathrm{x}$ 20mL), and dried to give phosphonate $\mathbf{5 0}$ as white solids $(11.5 \mathrm{~g}, 79 \%): \mathrm{mp}=79-80{ }^{\circ} \mathrm{C} ;{ }^{1} \mathrm{H}$ NMR (500 MHz, $\left.\mathrm{CDCl}_{3}\right) \delta 7.38-7.30(\mathrm{~m}, 5 \mathrm{H}), 5.60(\mathrm{~d}, J=7.9,1 \mathrm{H}), 5.15(\mathrm{AB}$ quart, $J=12.1$, $1 \mathrm{H}), 5.12$ (AB quart, $J=12.4,1 \mathrm{H}), 4.93(\mathrm{dd}, J=22.4,9.3,1 \mathrm{H}), 3.84-3.81$ (s, 3H and d, $J=12.0$, $3 \mathrm{H}), 3.79(\mathrm{~d}, J=11.0,3 \mathrm{H}) ;{ }^{13} \mathrm{C} \mathrm{NMR}\left(125 \mathrm{MHz}, \mathrm{CDCl}_{3}\right) \delta 167.3,155.7,135.9,128.6,128.4$, 128.2, 67.7, $54.3(\mathrm{~d}, J=6.4), 54.1(\mathrm{~d}, J=7.0), 53.5,52.1(\mathrm{~d}, J=147)$; IR (KBr) 3303, 3229, 3066, 3034, 2963, 2898, 2860, 1750, 1716, 1533, 1457, 1427, 1333, 1276, 1240, 1212, 1061, $1029 \mathrm{~cm}^{-1}$; HRMS (ESI/methanol) $m / z$ calcd for $\mathrm{C}_{13} \mathrm{H}_{18} \mathrm{NO}_{7} \mathrm{P}(\mathrm{M}+\mathrm{H})^{+} 332.0899$, found 332.0896 . 


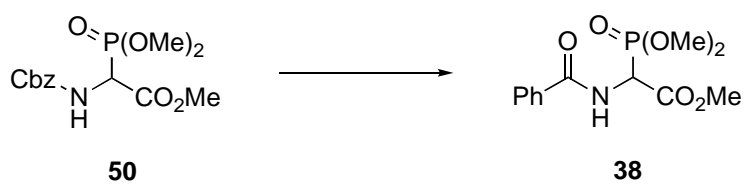

Phosphonate 38: Phosphonate 38 was synthesized using the procedure described by Coleman. ${ }^{10}$ A solution of phosphonate $\mathbf{5 0}(1.20 \mathrm{~g}, 3.61 \mathrm{mmol})$ and benzoic anhydride $(1.64 \mathrm{~g}, 7.10 \mathrm{mmol})$ in EtOAc $(15 \mathrm{~mL})$ was subjected to three cycles of evacuation $(30 \mathrm{sec})$ followed by purging with $\mathrm{N}_{2}$ (g). To this solution was added Pd/C (10\% Pd content, $\left.0.333 \mathrm{~g}, 0.313 \mathrm{mmol}, 8.7 \mathrm{~mol} \%\right)$. To the partially degassed suspension was introduced $\mathrm{H}_{2}(\mathrm{~g})$ (1atm) via a $\mathrm{H}_{2}(\mathrm{~g})$ filled balloon, followed by three cycles of evacuation $(30 \mathrm{sec})$ and purging with $\mathrm{H}_{2}(\mathrm{~g})$. The suspension was vigorously stirred over $\mathrm{H}_{2}(\mathrm{~g})$ for $3 \mathrm{~h}$. Excess $\mathrm{H}_{2}(\mathrm{~g})$ was removed by three cycles of evacuation (30 sec) and purging with $\mathrm{N}_{2}(\mathrm{~g})$. The suspension was filtered over a pad of Celite (1.5" thick), the pad was washed with $\mathrm{CH}_{2} \mathrm{Cl}_{2}(3 \times 50 \mathrm{~mL})$, and the filtrate was concentrated to provide a white solid. The solid was purified by flash chromatography (30:70 -60:40 EtOAc:hexanes) to give the 38 as a white solid $(0.965 \mathrm{~g}, 89 \%): \mathrm{mp}=100-105{ }^{\circ} \mathrm{C} ;{ }^{1} \mathrm{H} \mathrm{NMR}\left(500 \mathrm{MHz}, \mathrm{CDCl}_{3}\right) \delta$ 7.89-7.83 (m, 2H), 7.57-7.52 (m, 1H), 7.49-7.45 (m, 2H), $6.92(\mathrm{~d}, J=7.9,1 \mathrm{H}), 5.46(\mathrm{dd}, J=$ $21.9,8.8,1 \mathrm{H}), 3.89-3.87(\mathrm{~d}, J=11.1,3 \mathrm{H}$ and s, $3 \mathrm{H}), 3.82(\mathrm{~d}, J=11.0,3 \mathrm{H}) ;{ }^{13} \mathrm{C} \mathrm{NMR}(100 \mathrm{MHz}$ $\left.\mathrm{CDCl}_{3}\right) \delta 167.4(\mathrm{~d}, J=2.1), 167.1(\mathrm{~d}, J=5.6), 133.3,132.5,128.9,127.6,54.5,(\mathrm{~d}, J=6.4), 54.3$ (d, $J=6.9), 53.7,50.7$ (d, $J=146.9)$; IR (KBr) 3297, 3245, 3060, 3039, 2956, 2893, 2850, 1736, 1669, 1540, 1493, 1431, 1293, 1235, 1041, $1014 \mathrm{~cm}^{-1}$; HRMS (ESI/methanol) $\mathrm{m} / \mathrm{z}$ calcd for $\mathrm{C}_{12} \mathrm{H}_{16} \mathrm{NO}_{6} \mathrm{P}(\mathrm{M}+\mathrm{Na})^{+}$324.0613, found 324.0601.

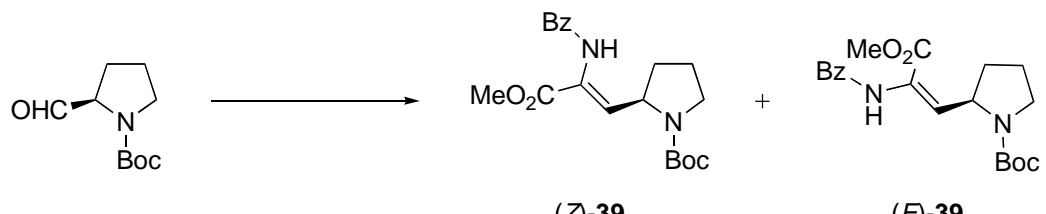

(Z)-39

$(E)-39$ 
Enamide 39: To a cooled solution of phosphonate 38 (0.965 g, $3.23 \mathrm{mmol})$ in $\mathrm{CH}_{2} \mathrm{Cl}_{2}(4 \mathrm{~mL})$ was added DBU $(0.36 \mathrm{~mL}, 3.16 \mathrm{mmol})$. After $20 \mathrm{~min}$, a solution of D-prolinal ${ }^{11}(0.526 \mathrm{~g}, 2.64$ mmol) in $\mathrm{CH}_{2} \mathrm{Cl}_{2}(2 \mathrm{~mL})$ was added. The reaction mixture was allowed to warm to room temperature over several hours and stirred for $20 \mathrm{~h}$. The reaction mixture was diluted with $\mathrm{H}_{2} \mathrm{O}$ $(20 \mathrm{~mL})$ and $1.0 \mathrm{~N} \mathrm{HCl}(10 \mathrm{~mL})$. After stirring for $2 \mathrm{~min}$, the reaction mixture was diluted with EtOAc $(30 \mathrm{~mL})$, the organic layer was separate, and the aqueous layer was extracted with EtOAc $(3 \times 30 \mathrm{~mL})$. The combined organic extracts were washed with saturated aqueous $\mathrm{NaHSO}_{3}(50$ $\mathrm{mL}$ ), brine (20 mL), dried over $\mathrm{MgSO}_{4}$, and concentrated to give an oil. ${ }^{1} \mathrm{H} \mathrm{NMR}$ analysis of the unpurified reaction mixture revealed a ratio of $(Z)-39:(E)-39=>30: 1$. The oil was purified by flash chromatography (gradient elution 20:80 - 30:70 EtOAc:hexanes) to yield (Z)-39 as a white solid (0.700 g) and (E)-39as a clear oil (0.023 g). (Combined yield $0.723 \mathrm{~g}, 73 \%$, enamide d.r. (Z)-39:(E)-39 = >30.0:1.0). The (Z)-39 was recrystallized from EtOAc:hexanes (10:90) to give rectangular crystals which were subjected to X-ray analysis (see Section III for X-ray data).

(Z)-39: $\mathrm{mp}=138-142{ }^{\circ} \mathrm{C} ;{ }^{1} \mathrm{H}$ NMR $\left(500 \mathrm{MHz}, \mathrm{DMSO}-d_{6}, 375 \mathrm{~K}\right) \delta 9.70$ (br s, $\left.1 \mathrm{H}\right), 7.94-7.91$ $(\mathrm{m}, 2 \mathrm{H}), 7.58(\mathrm{tt}, J=7.4,1.3,1 \mathrm{H}), 7.52-7.49(\mathrm{~m}, 2 \mathrm{H}), 6.25(\mathrm{~d}, J=8.6,1 \mathrm{H}), 4.56(\mathrm{td}, J=8.2$, 4.0, $1 \mathrm{H}), 3.70(\mathrm{~s}, 3 \mathrm{H}), 3.39-3.32(\mathrm{~m}, 2 \mathrm{H}), 2.18-2.11(\mathrm{~m}, 1 \mathrm{H}), 1.96-1.87(\mathrm{~m}, 1 \mathrm{H}), 1.86-1.75(\mathrm{~m}$, 2H), 1.43 (s, 9H); ${ }^{13} \mathrm{C}$ NMR (150 MHz, $\left.\mathrm{CDCl}_{3}\right) \delta 165.9,165.3,155.7,133.2,131.9,131.0,129.3$, 128.4, 127.9, 80.6, 53.3, 52.4, 46.5, 31.2, 28.5, 24.0; HRMS (ESI/methanol) $m / z$ calcd for $\mathrm{C}_{20} \mathrm{H}_{26} \mathrm{~N}_{2} \mathrm{O}_{5}(\mathrm{M}+\mathrm{Na})^{+}$397.1740, found 397.1730; [ $\left.\alpha\right]^{24}{ }_{\mathrm{D}}-283.0\left(c 0.31, \mathrm{CHCl}_{3}\right)$.

(E)-39: ${ }^{1} \mathrm{H}$ NMR (500 MHz, DMSO- $\left.d_{6}, 375 \mathrm{~K}\right) \delta 9.56$ (br s, 1H), 7.90-7.87 (m, 1H), 7.55 (tt, $J$ $=7.4,1.3,1 \mathrm{H}), 7.52-7.49(\mathrm{~m}, 2 \mathrm{H}), 6.10(\mathrm{dd}, J=8.9,0.54,1 \mathrm{H}), 4.87(\mathrm{td}, J=8.3,4.6,1 \mathrm{H}), 3.73 \mathrm{~s}$, $3 \mathrm{H}), 3.44-3.27(\mathrm{~m}, 2 \mathrm{H}), 2.24-2.18(\mathrm{~m}, 1 \mathrm{H}), 1.96-1.87(\mathrm{~m}, 1 \mathrm{H}), 1.86-1.75(\mathrm{~m}, 2 \mathrm{H}), 1.40(\mathrm{~s}, 9 \mathrm{H})$. (Only ${ }^{1} \mathrm{H}$ NMR data for this compound is given). 


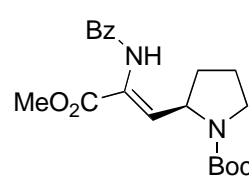

(Z)-39

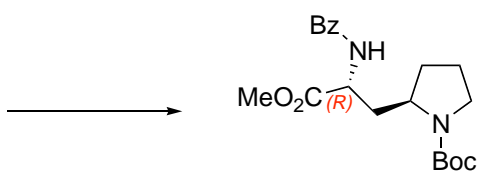

$40 a$

Amino Ester 40a: A solution of $(Z)-39$ : $(0.060 \mathrm{mg}, 0.160 \mathrm{mmol})$ was diluted in $i$-PrOH $(5.0$ $\mathrm{mL}$ ) and subjected to three cycles of evacuation $(30 \mathrm{sec})$ followed by purging with $\mathrm{N}_{2}(\mathrm{~g})$. To this solution was added Pd/C (10\% Pd content, $0.008 \mathrm{~g}, 0.007 \mathrm{mmol}, 3.5 \mathrm{~mol} \%)$. To the partially degassed suspension was introduced $\mathrm{H}_{2}$ (g) (1atm) via a $\mathrm{H}_{2}$ (g) filled balloon, followed by three cycles of evacuation $(30 \mathrm{sec})$ and purging with $\mathrm{H}_{2}(\mathrm{~g})$. The suspension was vigorously stirred for 2 h. Excess $\mathrm{H}_{2}(\mathrm{~g})$ was removed by three cycles of evacuation (30 sec) and purging with $\mathrm{N}_{2}(\mathrm{~g})$. The suspension was filtered over a pad of Celite (1.5" thick), the pad was washed with $\mathrm{CH}_{2} \mathrm{Cl}_{2}(5$ x $10 \mathrm{~mL}$ ), and concentrated in vacuo to give a yellow oil. ${ }^{1} \mathrm{H}$ NMR analysis of the unpurified material revealed d.r. $(\mathbf{4 0 a}: 40 \mathbf{b})=12.0: 1.00$. The oil was purified by flash chromatography (30:70 EtOAc:hexanes) to yield the 40a as colorless oil $(0.055$ g, $92 \%$, d.r. (40a:40b) $=$ 12.0:1.00): ${ }^{1} \mathrm{H}$ NMR (500 MHz, DMSO- $\left.d_{6}, 350 \mathrm{~K}\right) \delta 8.53(\mathrm{~d}, J=7.1,1 \mathrm{H}), 7.90-7.87(\mathrm{~m}, 2 \mathrm{H})$, 7.56-7.52 (m, 1H), 7.49-7.45 (m, 2H), $4.59(\mathrm{td}, J=8.1,4.9,1 \mathrm{H}), 3.91-3.86(\mathrm{~m}, 1 \mathrm{H}), 3.66(\mathrm{~s}$, $3 \mathrm{H}), 3.32(\mathrm{dt}, J=10.7,7.6,1 \mathrm{H}), 3.22(\mathrm{ddd}, J=10.8,7.8,4.6,1 \mathrm{H}), 2.16(\mathrm{ddd}, J=13.7,8.8,4.9$, 1H), 1.99-1.91 (m, 2H), 1.89-1.75 (m, 2H), 1.74-1.68 (m, 1H), $1.39(\mathrm{~s}, 9 \mathrm{H}) ;{ }^{13} \mathrm{C}$ NMR $(125$ $\mathrm{MHz}, \mathrm{CDCl}_{3}$, Only major rotamer reported at $\left.298 \mathrm{~K}\right) \delta 172.5,167.3,155.6,133.9,131.5,128.4$, 127.6, 80.1, 54.0, 52.4, 50.5, 46.3, 36.5, 31.1, 28.6, 23.5; IR (thin film) 3304, 3067, 2974, 2884 , 1747, 1691, 1664, 1539, 1399, 1366, $1169 \mathrm{~cm}^{-1}$; HRMS (ESI/methanol) $\mathrm{m} / \mathrm{z}$ calcd for $\mathrm{C}_{20} \mathrm{H}_{28} \mathrm{~N}_{2} \mathrm{O}_{5}(\mathrm{M}+\mathrm{Na})^{+}$399.1896, found 399.1899; $[\alpha]^{24}{ }_{\mathrm{D}}-18.3\left(c 0.24, \mathrm{CHCl}_{3}\right)$. 


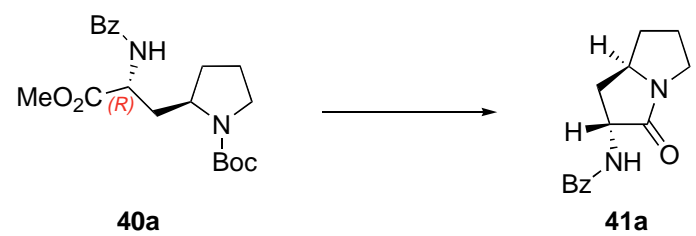

Lactam 41a: To a cooled $\left(0{ }^{\circ} \mathrm{C}\right)$ solution of $40 \mathrm{a}(0.083 \mathrm{~g}, 0.220 \mathrm{mmol})$ and 2,6 -lutidine $(0.100$ $\mathrm{mL}, 0.859 \mathrm{mmol})$ in $\mathrm{CH}_{2} \mathrm{Cl}_{2}(3.0 \mathrm{~mL})$ was added TMSOTf $(90.0 \mu \mathrm{L}, 0.496 \mathrm{mmol})$. After $2 \mathrm{~min}$, TLC analysis (30:70 EtOAc:hexanes) showed disappearance of starting material. To the reaction mixture was added saturated aqueous $\mathrm{NaHCO}_{3}(5 \mathrm{~mL})$ and $\mathrm{CH}_{2} \mathrm{Cl}_{2}(10 \mathrm{~mL})$. The reaction mixture was warmed to room temperature and stirred for $10 \mathrm{~min}$, then warmed to $40{ }^{\circ} \mathrm{C}$ in a water bath. After $24 \mathrm{~h}$, the reaction mixture was cooled to room temperature and extracted with $\mathrm{CH}_{2} \mathrm{Cl}_{2}(3 \times 20 \mathrm{~mL})$. The combined organic extracts were washed with $1.0 \mathrm{~N} \mathrm{NaHSO}_{4}(2 \times 10$ $\mathrm{mL}$ ), dried over $\mathrm{Na}_{2} \mathrm{SO}_{4}$, and concentrated to give a yellow solid. The solid were purified by flash chromatography (gradient elution 20:80 -100:0 EtOAc:hexanes) to afford bicyclic lactam 41a as a white solid $(0.033 \mathrm{~g}, 61 \%): \mathrm{mp}=181-183{ }^{\circ} \mathrm{C} ;{ }^{1} \mathrm{H}$ NMR $\left(600 \mathrm{MHz}, \mathrm{CDCl}_{3}\right) \delta 7.77-7.75$ (m, 2H), 7.45-7.43 (m, 1H), 7.37-7.35 (m, 2H and br s, $1 \mathrm{H}), 4.58(\mathrm{dt}, J=8.4,6.0,1 \mathrm{H}), 3.99(\mathrm{~m}$, $1 \mathrm{H}), 3.60(\mathrm{dt}, J=11.9,7.9,1 \mathrm{H}), 3.16(\mathrm{td}, J=10.7,3.3,1 \mathrm{H}), 2.34-2.29(\mathrm{~m}, 2 \mathrm{H}), 2.19-2.13(\mathrm{~m}$, 1H), 2.09-2.01 (m, 2H), 1.33-1.25 (m, 1H); $\left.{ }^{13} \mathrm{C} \mathrm{NMR} \mathrm{(150} \mathrm{MHz,} \mathrm{CDCl}_{3}\right) \delta$ 172.7, 167.6, 133.5, 131.6, 128.4, 127.1, 60.4, 55.8, 41.8, 32.0, 31.5, 26.5; HRMS (ESI/methanol) $\mathrm{m} / \mathrm{z}$ calcd for $\mathrm{C}_{14} \mathrm{H}_{16} \mathrm{~N}_{2} \mathrm{O}_{2}(\mathrm{M}+\mathrm{Na})^{+}$267.110, found 267.1105; IR (thin film) 3301, 3062, 2967, 1686, 1654, $1541 \mathrm{~cm}^{-1} ;[\alpha]_{D}^{24}+6.0\left(c 0.10, \mathrm{CHCl}_{3}\right)$.

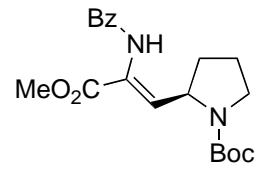

(Z)-39

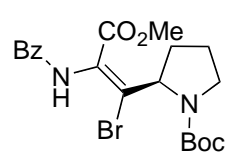

(Z)-Br-42

及-Bromo-Enamide 42: To a solution of $(Z)-39$ and $(E)-39(0.320 \mathrm{~g}, 0.850 \mathrm{mmol}$, ratio of (Z)-39:(E)-39 = 3.0:1.0) in $\mathrm{CHCl}_{3}(5 \mathrm{~mL})$ was added NBS $(0.197 \mathrm{~g}, 1.11 \mathrm{mmol}$, freshly 
re-crystallized from $\mathrm{H}_{2} \mathrm{O}$ ). The reaction suspension was stirred vigorously at room temperature and the progress of the reaction was monitored by TLC (30:70 EtOAc:hexanes). After 90 min, TLC analysis of the orange homogeneous mixture indicated consumption of starting material. To this mixture was added DABCO $(0.196 \mathrm{~g}, 1.75 \mathrm{mmol})$ in one portion. After $30 \mathrm{~min}$, reaction mixture was partitioned between $1.0 \mathrm{~N} \mathrm{NaHSO}_{4}(10 \mathrm{~mL})$ and $\mathrm{CH}_{2} \mathrm{Cl}_{2}(30 \mathrm{~mL})$. The aqueous layer was extracted with $\mathrm{CH}_{2} \mathrm{Cl}_{2}(3 \times 30 \mathrm{~mL})$ and the combined organic extracts were dried over $\mathrm{MgSO}_{4}$ and concentrated to give a yellow oil. The oil was purified by flash chromatography (gradient elution 30:70 - 50:50 EtOAc:hexanes) to yield the exclusively the $(Z)-\mathrm{Br}-\mathbf{4 2}$ as white solids $(0.277 \mathrm{~g}, 72 \%):{ }^{1} \mathrm{H}$ NMR (500 MHz, DMSO- $\left.d_{6}, 350 \mathrm{~K}\right) \delta 9.70(\mathrm{br} \mathrm{s}, 1 \mathrm{H}), 7.93$ (d, $J=7.3$, 2H), $7.58(\mathrm{tt}, J=7.4,1.3,1 \mathrm{H}), 7.51-7.48(\mathrm{~m}, 2 \mathrm{H}), 5.17(\mathrm{dd}, J=8.4,6.0,1 \mathrm{H}), 3.72(\mathrm{~s}, 3 \mathrm{H}), 3.54$ $(\mathrm{ddd}, J=10.6,7.1,3.9,1 \mathrm{H}), 3.36-3.31(\mathrm{~m}, 1 \mathrm{H}), 2.37-2.29(\mathrm{~m}, 1 \mathrm{H}), 2.03-1.96(\mathrm{~m}, 1 \mathrm{H}), 1.87-$ $1.78(\mathrm{~m}, 2 \mathrm{H}), 1.40(\mathrm{~s}, 9 \mathrm{H}) ;{ }^{13} \mathrm{C}$ NMR $\left(125 \mathrm{MHz}\right.$, DMSO- $d_{6}$, Only major rotamer reported at 298 K) $\delta 166.8,163.8,153.5,140.5,133.7,129.0,128.9,128.6,128.4,79.7,59.0,53.0,47.6,33.1$, 28.5, 24.1; IR (thin film) 3284, 2977, 1731, 1694, 1682, 1477, 1397, 1306, $1162 \mathrm{~cm}^{-1}$; HRMS (ESI/methanol) $m / z$ calcd for $\mathrm{C}_{20} \mathrm{H}_{25} \mathrm{BrN}_{2} \mathrm{O}_{5}(\mathrm{M}+\mathrm{Na})^{+} 475.0844$, found 475.0842; $[\alpha]^{24}{ }_{\mathrm{D}}+7.1(c$ $\left.0.13, \mathrm{CHCl}_{3}\right)$.

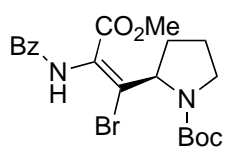

(Z)-Br-42

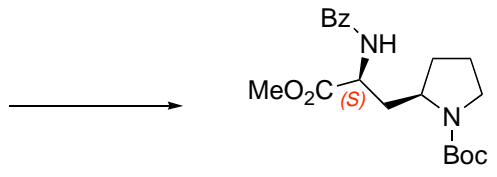

$40 b$

Amino Ester 40b: To a solution of Z-Br-enamide (Z)-Br-42 (0.024 mg, $0.050 \mathrm{mmol})$ was added $\mathrm{K}_{2} \mathrm{CO}_{3}(0.012 \mathrm{~g}, 0.080 \mathrm{mmol})$ and $i-\mathrm{PrOH}(4 \mathrm{~mL})$. The solution was subjected to three cycles of evacuation (30 sec) followed by purging with $\mathrm{N}_{2}(\mathrm{~g})$. Under a constant atmosphere of $\mathrm{N}_{2}(\mathrm{~g})$, $\mathrm{Pd} / \mathrm{C}(10 \% \mathrm{Pd}$ content, $0.012 \mathrm{~g}, 0.011 \mathrm{mmol}, 22 \mathrm{~mol} \%)$ was added. The reaction suspension was 
subjected to three cycles of evacuation ( $30 \mathrm{sec}$ ) followed by purging with $\mathrm{N}_{2}(\mathrm{~g})$. To the partially degassed suspension was introduced $\mathrm{H}_{2}(\mathrm{~g})$ (1atm) via a $\mathrm{H}_{2}(\mathrm{~g})$ filled balloon, followed by three cycles of evacuation ( $30 \mathrm{sec}$ ) and purging with $\mathrm{H}_{2}(\mathrm{~g})$. After $6 \mathrm{~h}$, excess $\mathrm{H}_{2}(\mathrm{~g})$ was removed by three cycles of evacuation $(30 \mathrm{sec})$ and purging with $\mathrm{N}_{2}(\mathrm{~g})$. The suspension was filtered over a pad of Celite (1.5" thick), the pad was washed with $\mathrm{CH}_{2} \mathrm{Cl}_{2}(5 \times 10 \mathrm{~mL})$ and concentration to give white foam. ${ }^{1} \mathrm{H}$ NMR analysis of the unpurified material revealed only one diastereomer. The foam was purified by flash chromatography (30:70 EtOAc:hexanes) to yield $\mathbf{4 0 b}$ as a white foam $(0.019 \mathrm{~g}, 95 \%):{ }^{1} \mathrm{H}$ NMR $\left(500 \mathrm{MHz}\right.$, DMSO$\left.d_{6}, 350 \mathrm{~K}\right) \delta 8.51(\mathrm{~d}, J=7.0,1 \mathrm{H}), 7.90-7.87$ (m, 2H), 7.56-7.52 (m, 1H), 7.49-7.45 (m, 2H), $4.51(\mathrm{td}, J=7.4,6.2,1 \mathrm{H}), 3.87-3.82(\mathrm{~m}, 1 \mathrm{H})$, 3.67 (s, 3H), $3.31(\mathrm{dt}, J=10.7,7.4,1 \mathrm{H}), 3.22(\mathrm{ddd}, J=10.6,7.7,4.7,1 \mathrm{H}), 2.25(\mathrm{ddd}, J=13.7$, 6.1, 4.3, 1H), 1.98-1.91 (m, 1H), 1.89-1.81 (m, 2H), 1.80-1.71 (m, 2H), $1.40(\mathrm{~s}, 9 \mathrm{H}) ;{ }^{13} \mathrm{C}$ NMR $\left(125 \mathrm{MHz}, \mathrm{CDCl}_{3}\right.$, Only major reported at $\left.298 \mathrm{~K}\right) \delta 172.2,167.7,155.5,133.7,131.5,128.4$, 127.6, 80.0, 53.6, 52.3, 51.8, 46.5, 37.6, 32.6, 28.5, 23.9; IR (thin film) 3304, 3069, 2974, 2886, 1749, 1693, 1663, 1539, 1398, 1366, $1167 \mathrm{~cm}^{-1}$; HRMS (ESI/methanol) $\mathrm{m} / \mathrm{z}$ calcd for $\mathrm{C}_{20} \mathrm{H}_{28} \mathrm{~N}_{2} \mathrm{O}_{5}(\mathrm{M}+\mathrm{Na})^{+} 399.1896$, found 399.1899; $[\alpha]^{25}-15.8\left(c 0.19, \mathrm{CHCl}_{3}\right)$.

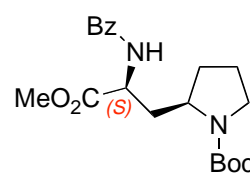

40b

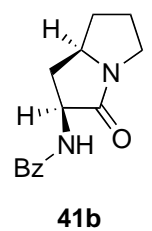

41b

Lactam 41b: To a cooled $\left(0{ }^{\circ} \mathrm{C}\right)$ solution of $40 \mathrm{~b}(0.061 \mathrm{~g}, 0.161 \mathrm{mmol})$ and 2,6 -lutidine $(0.100$ $\mathrm{mL}, 0.859 \mathrm{mmol})$ in $\mathrm{CH}_{2} \mathrm{Cl}_{2}(3 \mathrm{~mL})$ was added TMSOTf $(80.0 \mu \mathrm{L}, 0.442 \mathrm{mmol})$. After $2 \mathrm{~min}$, TLC analysis (30:70 EtOAc:hexanes) showed disappearance of starting material. To the reaction mixture was added saturated aqueous $\mathrm{NaHCO}_{3}(3 \mathrm{~mL})$ and $\mathrm{CH}_{2} \mathrm{Cl}_{2}(10 \mathrm{~mL})$. The reaction mixture was warmed to room temperature and stirred for $10 \mathrm{~min}$, then warmed to $40{ }^{\circ} \mathrm{C}$ in a 
water bath. After $24 \mathrm{~h}$, the reaction mixture was cooled to room temperature and extracted with $\mathrm{CH}_{2} \mathrm{Cl}_{2}(3 \times 20 \mathrm{~mL})$. The combined organic extracts were washed with $1.0 \mathrm{~N} \mathrm{NaHSO}_{4}(2 \times 10$ $\mathrm{mL}$ ), dried over $\mathrm{Na}_{2} \mathrm{SO}_{4}$, and concentrated to give a yellow solid. The solid were purified by flash chromatography (gradient elution 20:80 -100:0 EtOAc:hexanes) to afford bicyclic lactam 41b as a white solid $(0.029 \mathrm{~g}, 74 \%)$. The solids were recrystallized from EtOAc to give needle-like crystals that were submitted for X-ray analysis (see Section III for X-ray data): ${ }^{1} \mathrm{H}$ NMR (600 MHz, $\left.\mathrm{CDCl}_{3}\right) \delta$ 7.80-7.79 (m, 2H), 7.52-7.45 (m, 1H), 7.40-7.37 (m, 2H), 7.20 (d, J $=4.1,1 \mathrm{H}), 4.94-4.90(\mathrm{~m}, 1 \mathrm{H}), 3.85(\mathrm{dddd}, J=11.4,9.0,5.8,5.8,1 \mathrm{H}), 3.58(\mathrm{dt}, J=11.4,8.0$, 1H), 3.17-3.10 (m, 2H), 2.16-2.08 (m, 3H), $1.64(\mathrm{td}, J=11.7,9.0,1 \mathrm{H}), 1.44-1.37(\mathrm{~m}, 1 \mathrm{H}) ;{ }^{13} \mathrm{C}$ NMR $\left(150 \mathrm{MHz}, \mathrm{CDCl}_{3}\right) \delta 171.9,167.5,133.6,131.6,128.4,127.1,58.4,55.7,41.5,38.5,32.1$, 26.5; IR (thin film) 3301, 3062, 2967, 1686, 1654, $1541 \mathrm{~cm}^{-1} ;$ HRMS (ESI/methanol) $\mathrm{m} / \mathrm{z}$ calcd for $\mathrm{C}_{14} \mathrm{H}_{16} \mathrm{~N}_{2} \mathrm{O}_{2}(\mathrm{M}+\mathrm{Na})^{+}$267.1110, found 267.1104; $[\alpha]^{25}{ }_{\mathrm{D}}-72.6\left(c 0.13, \mathrm{CHCl}_{3}\right)$.

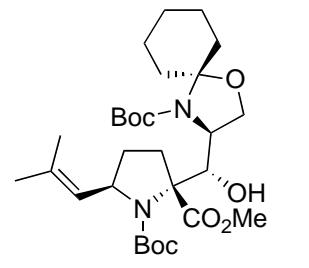

$31 a$

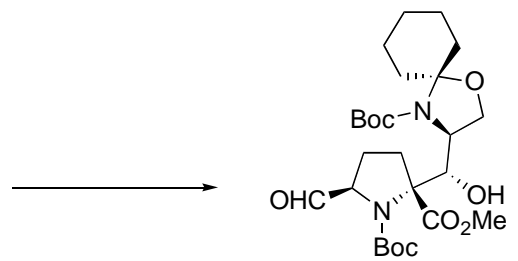

52

Aldehyde 52: To a cooled $\left(-78^{\circ} \mathrm{C}\right)$ and stirred solution of $\mathbf{3 1 a}(3.44 \mathrm{~g}, 6.22 \mathrm{mmol})$ in $\mathrm{CH}_{2} \mathrm{Cl}_{2}$ $(60 \mathrm{~mL})$ was passed a stream of $\mathrm{O}_{3}(\mathrm{~g})$. The progress of the reaction was monitored by TLC (30:70 EtOAc:hexanes). The reaction was deemed complete after TLC analysis showed disappearance of starting material or after the persistence of a blue/purple hue of the reaction mixture, at which point the flow of $\mathrm{O}_{3}(\mathrm{~g})$ was discontinued and $\mathrm{O}_{2}(\mathrm{~g})$ was passed through the reaction mixture $(2 \mathrm{~min})$ to remove excess ozone. A solution of triphenyl phosphine $(2.29 \mathrm{~g}, 8.74$ mmol) in $\mathrm{CH}_{2} \mathrm{Cl}_{2}(10 \mathrm{~mL})$ was carefully added and reaction was allowed to stir at $-78{ }^{\circ} \mathrm{C}$. After 1 $\mathrm{h}$, the reaction was warmed to $0{ }^{\circ} \mathrm{C}$, then gradually to room temperature and stirred for a total of 
$4 \mathrm{~h}$. Concentration of the resultant mixture followed by immediate purification by flash chromatography (gradient elution 20:80 - 30:80 EtOAc:hexanes) yielded 52 as a white solids (3.00 g, 91\%): ${ }^{1} \mathrm{H}$ NMR $\left(500 \mathrm{MHz}, \mathrm{DMSO}-d_{6}, 375 \mathrm{~K}\right) \delta 9.50(\mathrm{~d}, J=3.2,1 \mathrm{H}), 4.57$ (br s, $\left.1 \mathrm{H}\right)$, 4.19-4.15 (m, 2H), 4.09-4.06 (m, 1H), $3.84(\mathrm{dd}, J=8.9,6.8,1 \mathrm{H}), 3.71(\mathrm{~s}, 3 \mathrm{H}), 2.45(\mathrm{~m}, 1 \mathrm{H})$, $2.24-2.15(\mathrm{~m}, 1 \mathrm{H}$ and $\mathrm{dd}, J=7.2,5.9,1 \mathrm{H}), 2.13-2.04(\mathrm{~m}, 2 \mathrm{H}), 1.83-1.77(\mathrm{~m}, 2 \mathrm{H}), 1.61-1.55$ (m, 3H), 1.53-1.46 (m, 4H and s, 9H), $1.43(\mathrm{~s}, 9 \mathrm{H}), 1.15-1.07(\mathrm{~m}, 1 \mathrm{H}) ;{ }^{13} \mathrm{C}$ NMR $(125 \mathrm{MHz}$ $\mathrm{CDCl}_{3}$, only major rotamer reported at $\left.298 \mathrm{~K}\right) \delta 200.3,172.5,156.0,152.8,95.0,83.5,80.4$, $75.7,74.0,68.0,62.9,57.9,53.1,35.2,34.2,32.1,28.6,28.2,25.1,24.4,23.6,23.5$; IR (thin film) $3335,2976,2933,2864,3720,1737,1684,1455,1393,1368,1256,1162 \mathrm{~cm}^{-1}$; HRMS (ESI/methanol) $m / z$ calcd for $\mathrm{C}_{26} \mathrm{H}_{42} \mathrm{~N}_{2} \mathrm{O}_{9}(\mathrm{M}+\mathrm{Na})^{+} 549.2788$, found $549.2783 ;[\alpha]^{24}{ }_{\mathrm{D}}-12.2(c$ $\left.0.62, \mathrm{CHCl}_{3}\right)$.

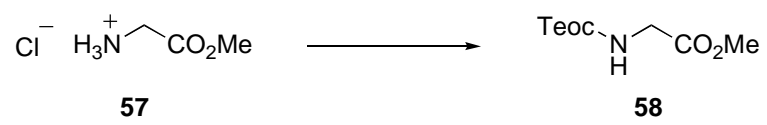

$N$-Teoc Glycine Ester 58: Glycine methyl ester hydrochloride 57 (8.68 g, $69.1 \mathrm{mmol})$ was diluted in a mixture of $\mathrm{THF} / \mathrm{H}_{2} \mathrm{O}(140 \mathrm{~mL}, 1: 1$ mixture). The bi-phasic mixture was stirred at 0 ${ }^{\circ} \mathrm{C}$ and $\mathrm{K}_{2} \mathrm{CO}_{3}(23.9 \mathrm{~g}, 173 \mathrm{mmol})$ were added, followed by the dropwise addition of a solution of Teoc-Cl in toluene (freshly prepared $54 \%$ wt solution, $15.5 \mathrm{~g}$, $46.5 \mathrm{mmol}$ ). After $90 \mathrm{~min}$, the reaction mixture was allowed warm to room temperature and stirred over $24 \mathrm{~h}$. The reaction mixture was partitioned between EtOAc $(200 \mathrm{~mL})$ and $\mathrm{H}_{2} \mathrm{O}(100 \mathrm{~mL})$. The organic layer was separated and the aqueous layer was extracted with EtOAc $(3 \times 150 \mathrm{~mL})$. The combined organic extracts were washed with $1.0 \mathrm{~N} \mathrm{NaHSO}_{4}(3 \times 50 \mathrm{~mL})$, brine $(150 \mathrm{~mL})$, dried over $\mathrm{MgSO}_{4}$, and concentrated in vacuo to give a clear oil. The oil was purified by flash chromatography (20:80 EtOAc:hexanes) to yield the product 58 as a clear oil (10.5 g, 97\%): ${ }^{1} \mathrm{H}$ NMR (500 MHz, $\mathrm{CDCl}_{3}$ ) 


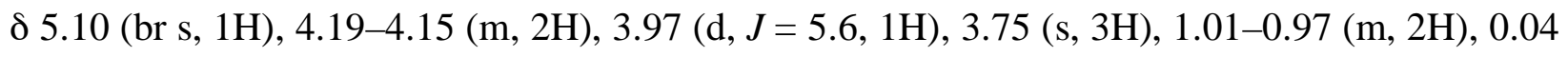
(s, 9H); ${ }^{13} \mathrm{C} \mathrm{NMR}\left(125 \mathrm{MHz}, \mathrm{CDCl}_{3}\right) \delta 170.7,156.7,63.7,52.4,42.6,17.7,-1.4 ;$ IR (thin film) 3266, 3008, 2956, 2899, 2856, 1748, 1714, 1531, 1437, 1312, 1215, 1181, $1038 \mathrm{~cm}^{-1}$; HRMS (ESI/methanol) $\mathrm{m} / \mathrm{z}$ calcd for $\mathrm{C}_{9} \mathrm{H}_{19} \mathrm{NO}_{4} \mathrm{Si}(\mathrm{M}+\mathrm{Na})^{+} 256.0981$, found 256.0983

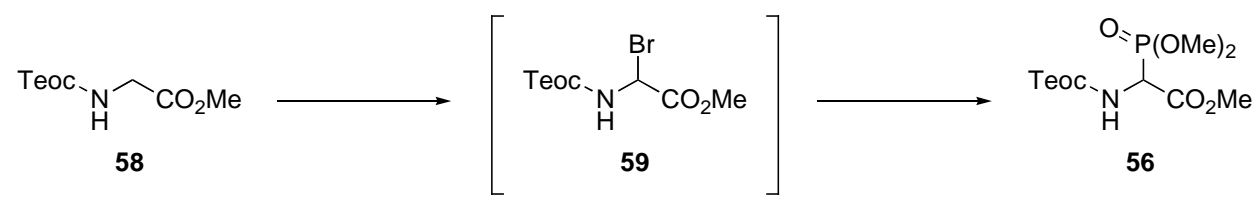

Phosphonate 56: To a solution of $\mathbf{5 8}(5.08 \mathrm{~g}, 21.8 \mathrm{mmol})$ in $\mathrm{CCl}_{4}(50 \mathrm{~mL})$ was added NBS (4.48 g, $25.2 \mathrm{mmol}$, freshly re-crystallized from $\mathrm{H}_{2} \mathrm{O}$ ). The reaction suspension was stirred at room temperature until TLC analysis (30:70 EtOAc:hexanes) indicated consumption of starting material $(4-5 \mathrm{~h})$. Pentanes $(50 \mathrm{~mL})$ was added to the reaction suspension and after stirring for 15 min, the resultant heterogeneous reaction mixture was filtered over Celite. The Celite pad was washed with pentanes $(4 \times 50 \mathrm{~mL})$ and the filtrate was concentrated in vacuo to give a $\mathbf{5 9}$ as a light yellow oil. The oil was immediately diluted with THF $(50 \mathrm{~mL})$, and $\mathrm{P}(\mathrm{OMe})_{3}(3.40 \mathrm{~mL}$, $28.8 \mathrm{mmol}$ ) was added. After $24 \mathrm{~h}$, the colorless reaction mixture was concentrated to give an oil. The oil was purified by flash chromatography (gradient elution 50:50 - 90:10 EtOAc:hexanes) to afford the product 56 as a clear colorless oil $(3.72 \mathrm{~g}, 50 \%):{ }^{1} \mathrm{H} \mathrm{NMR}\left(500 \mathrm{MHz}, \mathrm{CDCl}_{3}\right) \delta 5.43$ $(\mathrm{d}, J=10.7,1 \mathrm{H}), 4.92(\mathrm{dd}, J=28.1,11.6,1 \mathrm{H}), 4.21-4.16(\mathrm{~m}, 2 \mathrm{H}), 3.84(\mathrm{~d}, J=7.4,3 \mathrm{H}), 3.83(\mathrm{~s}$, $3 \mathrm{H}), 3.81(\mathrm{~d}, J=7.4,3 \mathrm{H}), 1.02-0.98(\mathrm{~m}, 2 \mathrm{H}), 0.04(\mathrm{~s}, 9 \mathrm{H}) ;{ }^{13} \mathrm{C} \mathrm{NMR}\left(125 \mathrm{MHz}, \mathrm{CDCl}_{3}\right) \delta$ 167.5, 156.4, 64.4, $54.2(\mathrm{~d}, J=6.4), 54.1$ (d, $J=6.6), 53.4,52.4(\mathrm{~d}, J=147)$; IR (thin film) 3265 , $3008,2955,2899,2855,1753,1715,1531,1437,1313,1250,1181,1045 \mathrm{~cm}^{-1}$; HRMS (ESI/methanol) $m / z$ calcd for $\mathrm{C}_{11} \mathrm{H}_{24} \mathrm{NO}_{7} \mathrm{PSi}(\mathrm{M}+\mathrm{Na})^{+} 364.0957$, found 364.0948. 


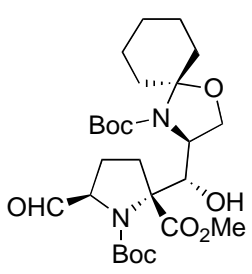

52

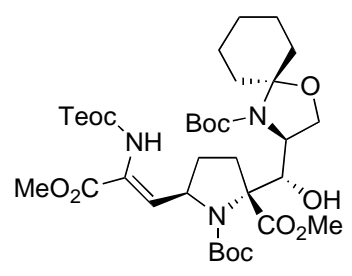

(Z)-47

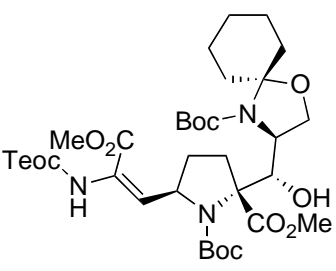

$(E)-47$

Enamide 47: $N$-Teoc Phosphonate $56(2.73 \mathrm{~g}, 8.00 \mathrm{mmol})$ was azeotropically dried from toluene $(4 \times 50 \mathrm{~mL})$, followed by further drying in vacuo $(0.5 \mathrm{mmHg})$ for $24 \mathrm{~h}$. The phosphonate was diluted with THF $(21 \mathrm{~mL})$, cooled to $0{ }^{\circ} \mathrm{C}$, and a solution of LDA (1.0 M in THF, $6.60 \mathrm{~mL}$, $6.67 \mathrm{mmol}$ ) was added dropwise over $10 \mathrm{~min}$. The temperature was maintained at $0{ }^{\circ} \mathrm{C}$ and resulting yellow solution was allowed to stir for $1 \mathrm{~h}$, then further cooled to $-78^{\circ} \mathrm{C}$. A solution of aldehyde $52(2.85 \mathrm{~g}, 5.41 \mathrm{mmol})$ in THF $(25.0 \mathrm{~mL})$ was transferred via a cannula (care was taken to add the aldehyde solution slowly along the side of the flask to allow for cooling). The stirred reaction mixture was allowed to gradually warm to ambient temperature over $24 \mathrm{~h}$, which resulted in a murky yellow suspension. The murky suspension was cooled $\left(0^{\circ} \mathrm{C}\right)$, quenched with 1.0 $\mathrm{N} \mathrm{NaHSO}_{4}(20 \mathrm{~mL})$, and diluted with EtOAc $(20 \mathrm{~mL})$. The organic layer was separated and the aqueous layer was extracted with EtOAc $(4 \times 100 \mathrm{~mL})$. The combined organic extracts were washed with brine $(100 \mathrm{~mL})$, dried over $\mathrm{MgSO}_{4}$, and concentrated in vacuo to give a yellow foam. Normal phase HPLC analysis (15:85 $i$-PrOH:hexanes, $1.0 \mathrm{~mL} / \mathrm{min}, 254 \mathrm{~nm})$ of the unpurified material revealed a dehydroamino ester ratio of $(E)-\mathbf{4 7 :}(Z)-47=1.12: 1.00$. The foam was purified by flash chromatography (gradient elution 10:90 - 20:80 - 100:0 EtOAc:hexanes) to provide a separable mixture of $(E)-47$ and (Z)-47as a white foam (combined yield $4.00 \mathrm{~g}$, 100\%, 1:1 mixture of $(E)-47:(Z)-47)$ :

(E)-47: ${ }^{1} \mathrm{H}$ NMR $\left(500 \mathrm{MHz}, \mathrm{DMSO}-d_{6}, 375 \mathrm{~K}\right) \delta 8.28(\mathrm{~s}, 1 \mathrm{H}), 6.25(\mathrm{~d}, J=8.8,1 \mathrm{H}), 5.13(\mathrm{br} \mathrm{d}, J$ $=8.0,1 \mathrm{H}), 5.00(\operatorname{app} \mathrm{ddd}, J=8.2,8.2,3.2,1 \mathrm{H}), 4.43(\mathrm{dd}, J=9.3,1.9,1 \mathrm{H}), 4.15-4.11(\mathrm{~m}, 2 \mathrm{H})$, 
$4.08(\mathrm{ddd}, J=6.9,3.1,2.1,1 \mathrm{H}), 4.03(\mathrm{dd}, J=8.9,3.2,1 \mathrm{H}), 3.83(\mathrm{dd}, J=8.9,6.9,1 \mathrm{H}), 3.71(\mathrm{~s}$, $3 \mathrm{H}$ and $\mathrm{s}, 3 \mathrm{H}), 2.42(\mathrm{ddd}, J=12.5,7.6,4.2,1 \mathrm{H}), 2.29-2.14(\mathrm{~m}, 3 \mathrm{H}), 2.10(\mathrm{td}, J=13.4,4.4,1 \mathrm{H})$, 1.80-1.77 (m, 1H), 1.65-1.58 (m, 4H), 1.54-1.47 (m, 3H and s, 9H), $1.39(\mathrm{~s}, 9 \mathrm{H}), 1.16-1.07(\mathrm{~m}$, 1H), $1.00-0.96(\mathrm{~m}, 2 \mathrm{H}), 0.05(\mathrm{~s}, 9 \mathrm{H}) ;{ }^{13} \mathrm{C} \mathrm{NMR}\left(125 \mathrm{MHz}, \mathrm{CDCl}_{3}\right.$, only major rotamer reported at $298 \mathrm{~K}) \delta 173.1,163.9,156.8,153.7,152.8,131.8,124.0,94.6,81.8,80.2,75.0,74.2,63.6$, $62.3,59.7,58.1,52.9,52.6,34.5,32.5,31.2,28.7,28.6,28.2,25.2,23.7,23.5,17.7,-1.4$; IR (thin film) 3330, 2953, 1733, 1700, 1677, 1517, 1452, 1438, 1390, 1366, 1250, $1165 \mathrm{~cm}^{-1}$; HRMS (ESI/methanol) $m / z$ calcd for $\mathrm{C}_{35} \mathrm{H}_{59} \mathrm{~N}_{3} \mathrm{O}_{12} \mathrm{Si}(\mathrm{M}+\mathrm{Na})^{+} 764.3766$, found 764.3746; $[\alpha]_{\mathrm{D}}^{23}-9.3\left(c 0.85, \mathrm{CHCl}_{3}\right)$.

(Z)-47: ${ }^{1} \mathrm{H}$ NMR (500 MHz, DMSO-d $\left.d_{6}, 375 \mathrm{~K}\right) \delta 8.05$ (s, $\left.1 \mathrm{H}\right), 6.46(\mathrm{dd}, J=8.5,0.8,1 \mathrm{H}), 5.09$ (br s, 1H), $4.69(\operatorname{app~td}, J=8.1,3.9,1 \mathrm{H}), 4.46(\mathrm{~d}, J=7.6,1 \mathrm{H}), 4.15-4.08(\mathrm{~m}, 3 \mathrm{H}), 4.03(\mathrm{dd}, J=$ 8.9, 3.3, 1H), $3.83(\mathrm{dd}, J=8.9,6.9,1 \mathrm{H}), 3.71(\mathrm{~s}, 3 \mathrm{H}), 3.70(\mathrm{~s}, 3 \mathrm{H}), 2.42-2.38(\mathrm{~m}, 1 \mathrm{H}), 2.24-2.12$ (m, 3H), $2.10(\mathrm{td}, J=13.3,4.4,1 \mathrm{H}), 1.80-1.78(\mathrm{~m}, 1 \mathrm{H}), 1.70-1.65(\mathrm{~m}, 1 \mathrm{H}), 1.60-1.57(\mathrm{~m}, 3 \mathrm{H})$, 1.53-1.46 (m, 3H and s, 9H), $1.40(\mathrm{~s}, 9 \mathrm{H}), 1.15-1.08(\mathrm{~m}, 1 \mathrm{H}), 0.98-0.95(\mathrm{~m}, 2 \mathrm{H}), 0.05(\mathrm{~s}, 9 \mathrm{H})$; ${ }^{13} \mathrm{C} \mathrm{NMR}\left(125 \mathrm{MHz}, \mathrm{CDCl}_{3}\right.$, only major rotamer reported at $\left.298 \mathrm{~K}\right) \delta 173.1,165.3,156.7,154.7$, $152.8,134.7,124.5,94.7,82.1,80.2,74.9,74.6,64.3,62.4,59.3,58.0,53.0,52.8,34.6,34.4$, 32.5, 29.0, 28.6, 28.4, 25.1, 23.7, 23.5, 17.6, -1.4; IR (thin film) 3319, 3008, 2953, 2934, 2864, 1726, 1701, 1679, 1477, 1454, 1391, 1366, 1251, $1170 \mathrm{~cm}^{-1}$; HRMS (ESI/methanol) $\mathrm{m} / \mathrm{z}$ calcd for $\mathrm{C}_{35} \mathrm{H}_{59} \mathrm{~N}_{3} \mathrm{O}_{12} \mathrm{Si}(\mathrm{M}+\mathrm{Na})^{+} 764.3766$, found 764.3763; $[\alpha]^{23}{ }_{\mathrm{D}}-67.8\left(c 0.59, \mathrm{CHCl}_{3}\right)$.

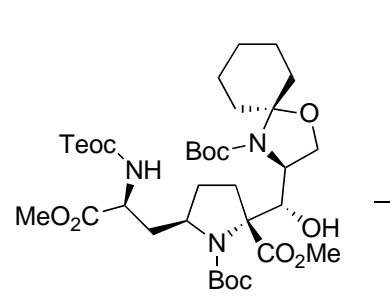

$62 \mathrm{a}$
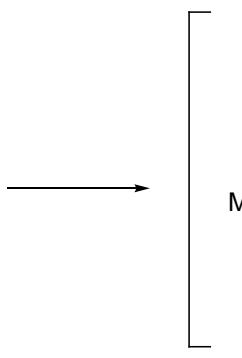

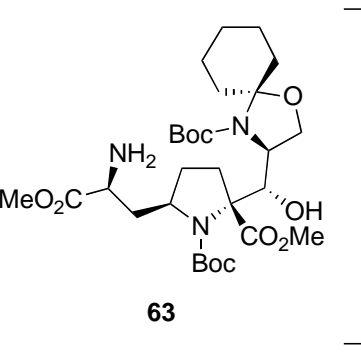

63

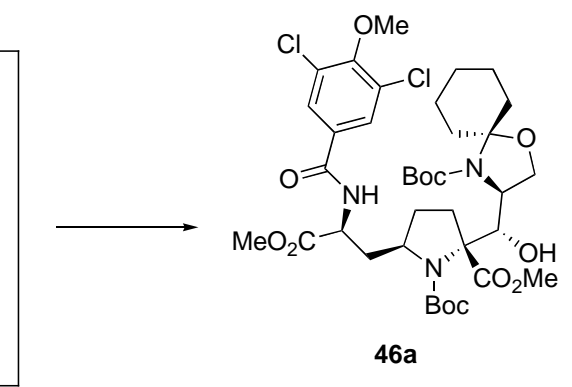


Amino Ester 46a: To a vigorously stirred suspension of CsF (1.62 g, 10.6 mmol, freshly dried under $0.5 \mathrm{mmHg}$ at $100{ }^{\circ} \mathrm{C}$ for $\left.2 \mathrm{~h}\right)$ in anhydrous DMSO $(2 \mathrm{~mL})$ was added a solution of 62a (1.27 g, $1.71 \mathrm{mmol})$ in anhydrous DMSO (20 mL). After $13 \mathrm{~h}$, TLC (30:70 EtOAc:hexanes) analysis showed consumption of starting material. The suspension was cooled $\left(0{ }^{\circ} \mathrm{C}\right), \mathrm{Et}_{2} \mathrm{O}(50$ $\mathrm{mL})$ and $\mathrm{H}_{2} \mathrm{O}(100 \mathrm{~mL})$ were added, and the mixture was stirred for $15 \mathrm{~min}$ until all solids dissolved. The clear biphasic mixture was separated and the aqueous layer was extracted with additional $\mathrm{Et}_{2} \mathrm{O}(4 \times 75 \mathrm{~mL})$. The combined organic extracts were washed with $\mathrm{H}_{2} \mathrm{O}(2 \times 100$ $\mathrm{mL})$, brine $(150 \mathrm{~mL})$, dried over $\mathrm{MgSO}_{4}$, and concentrated in vacuo to give free amine $\mathbf{6 3}$ as a clear oil. The oil was immediately carried forward to the next step.

Free amine 63 was immediately diluted with $\mathrm{CH}_{2} \mathrm{Cl}_{2}(20 \mathrm{~mL})$ and transferred via cannula to a chilled $\left(0^{\circ} \mathrm{C}\right)$ premixed solution of carboxylic acid $79(0.776 \mathrm{~g}, 3.51 \mathrm{mmol})$ and EDCI $(0.658 \mathrm{~g}, 3.43 \mathrm{mmol})$ in $\mathrm{CH}_{2} \mathrm{Cl}_{2}(20 \mathrm{~mL})$. After $6 \mathrm{~h}$ at room temperature, the reaction mixture was concentrated in vacuo to afford a thick paste. The paste was partitioned between EtOAc (75 $\mathrm{mL})$ and $\mathrm{H}_{2} \mathrm{O}(50 \mathrm{~mL})$, the organic layer was separated, and the aqueous layer was extracted with EtOAc $(4 \times 75 \mathrm{~mL})$. The combined organic extracts were washed with saturated $\mathrm{NaHCO}_{3}(2 \times 75$ $\mathrm{mL}), \mathrm{H}_{2} \mathrm{O}(2 \times 50 \mathrm{~mL})$, brine $(50 \mathrm{~mL})$, dried over $\mathrm{MgSO}_{4}$, and concentrated to give an off-white solid. Normal phase HPLC analysis (15:85 $i$-PrOH:hexanes, $1.0 \mathrm{~mL} / \mathrm{min}, 254 \mathrm{~nm}$ ) of the unpurified material revealed d.r. $(\mathbf{4 6 a}: 46 b)=21.6: 1.00$. The solid was purified by flash chromatography (25:75 EtOAc:hexanes) to yield 46a as a white foam (1.29 g, 94\%):

46a: ${ }^{1} \mathrm{H}$ NMR $\left(500 \mathrm{MHz}, \mathrm{DMSO}-d_{6}, 385 \mathrm{~K}\right) \delta 8.63(\mathrm{~d}, J=7.5,1 \mathrm{H}), 7.95(\mathrm{~s}, 2 \mathrm{H}), 5.20$ (br s, 1H), 4.54 (app dd, $J=14.4,7.6,1 \mathrm{H}), 4.46(\mathrm{~d}, J=8.1,1 \mathrm{H}), 4.05-4.00(\mathrm{~m}, 2 \mathrm{H}), 3.98(\mathrm{dd}, J=8.8$. 3.5, 1H), $3.94(\mathrm{~s}, 3 \mathrm{H}), 3.84(\mathrm{dd}, J=8.8,7.0,1 \mathrm{H}), 3.70(\mathrm{~s}, 6 \mathrm{H}), 2.46-2.39(\mathrm{ddd}, J=13.9,6.4,2.1$, $1 \mathrm{H}$ and $\mathrm{m}, 1 \mathrm{H}), 2.27-2.17(\mathrm{ddd}, J=13.5,12.2,7.7,1 \mathrm{H}$ and $\mathrm{td}, J=13.6,4.7,1 \mathrm{H}), 2.09(\mathrm{td}, J=$ 
$13.4,4.4,1 \mathrm{H}), 2.00$ (dddd, $J=12.3,12.3,7.8,7.8,1 \mathrm{H}), 1.86-1.76(\mathrm{ddd}, J=14.0,9.9,7.7,1 \mathrm{H}$ and $\mathrm{m}, 2 \mathrm{H}), 1.63-1.58(\mathrm{~m}, 3 \mathrm{H}), 1.55-1.51(\mathrm{~m}, 1 \mathrm{H}), 1.50-1.48(\mathrm{~s}, 9 \mathrm{H}$ and $\mathrm{m}, 1 \mathrm{H}), 1.48-1.45(\mathrm{~m}$, $1 \mathrm{H}$ and s, 9H), $1.15-1.06(\mathrm{~m}, 1 \mathrm{H}) ;{ }^{13} \mathrm{C} \mathrm{NMR}\left(125 \mathrm{MHz}, \mathrm{CDCl}_{3}\right.$, only major rotamer reported at 298 K) $\delta 173.2,172.4,164.2,156.5,155.4,152.8,130.0,129.5,127.9,94.6,82.3,80.3,75.5$, 73.5, 61.9, 61.0, 59.4, 58.0, 53.0, 52.9, 51.7, 36.0, 34.5, 33.9, 32.6, 28.6, 28.5, 28.4, 25.1, 23.6, 23.5; IR (thin film) 3318, 3077, 3008, 2973, 2934, 2864, 1748, 1678, 1592, 1551, 1477, 1391, 1368, 1252, $1162 \mathrm{~cm}^{-1}$; HRMS (ESI/methanol) $m / z$ calcd for $\mathrm{C}_{37} \mathrm{H}_{53} \mathrm{Cl}_{2} \mathrm{~N}_{3} \mathrm{O}_{12}(\mathrm{M}+\mathrm{Na})^{+}$ 824.2904, found 824.2905; $[\alpha]^{23}{ }_{\mathrm{D}}-22.9\left(c 0.48, \mathrm{CHCl}_{3}\right)$.

46b: ${ }^{1} \mathrm{H}$ NMR (500 MHz, DMSO- $\left.d_{6}, 385 \mathrm{~K}\right) \delta 8.66(\mathrm{~d}, J=7.5,1 \mathrm{H}), 8.00(\mathrm{~s}, 2 \mathrm{H}), 5.20(\mathrm{br} \mathrm{s}$, $1 \mathrm{H}), 4.50(\mathrm{ddd}, J=9.5,7.9,4.6,1 \mathrm{H}), 4.44(\mathrm{dd}, J=9.4,1.3,1 \mathrm{H}), 4.06-4.03(\mathrm{~m}, 1 \mathrm{H}), 3.99-3.95$ (m, 2H), $3.93(\mathrm{~s}, 3 \mathrm{H}), 3.82(\mathrm{dd}, J=8.8,7.0,1 \mathrm{H}), 3.70(\mathrm{~s}, 3 \mathrm{H}), 3.69(\mathrm{~s}, 3 \mathrm{H}), 2.46-2.40(\mathrm{~m}, 1 \mathrm{H})$, 2.30-2.16 (m, 3H), 2.07 (td, $J=13.4,4.1,1 \mathrm{H}), 2.04-1.99(\mathrm{~m}, 1 \mathrm{H}), 1.93$ (ddd, $J=14.2,9.9,4.5$, 1H), 1.80-1.71 (m, 2H), 1.61-1.55 (m, 3H), 1.53-1.49 (m, 2H), 1.47-1.45 (m, 1H and s, 9H), $1.43(\mathrm{~s}, 9 \mathrm{H}), 1.15-1.09(\mathrm{~m},, 1 \mathrm{H}) ;{ }^{13} \mathrm{C}$ NMR $\left(125 \mathrm{MHz}, \mathrm{CDCl}_{3}\right.$, only major rotamer reported at 298 K) $\delta 174.2,172.6,165.0,156.5,155.2,152.9,130.7,129.8,128.2,94.7,82.7,80.4,75.7$, 73.9, 61.9, 61.0, 59.5, 57.8, 53.3, 52.9, 52.0, 35.9 34.4, 34.0, 32.6, 28.5, 28.5, 28.4, 25.1, 23.6, 23.4; IR (thin film) 3332, 2970, 2934, 2862, 1746, 1676, 1476, 1390, 1368, 1272, $1160 \mathrm{~cm}^{-1}$; HRMS (ESI/methanol) $m / z$ calcd for $\mathrm{C}_{37} \mathrm{H}_{53} \mathrm{Cl}_{2} \mathrm{~N}_{3} \mathrm{O}_{12}(\mathrm{M}+\mathrm{Na})^{+}$824.2904, found 824.2921; $[\alpha]^{23}{ }_{D}-27.7\left(c 0.39, \mathrm{CHCl}_{3}\right)$.

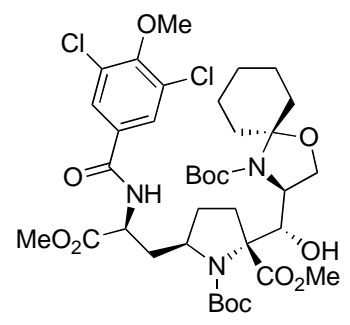

$46 a$

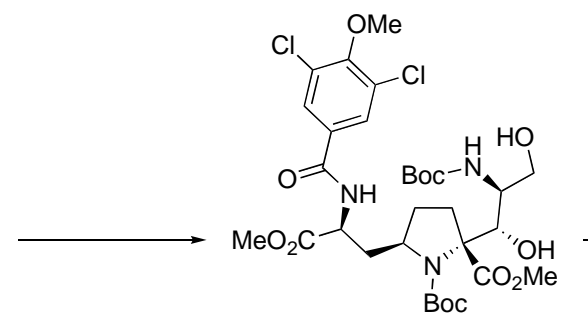

64

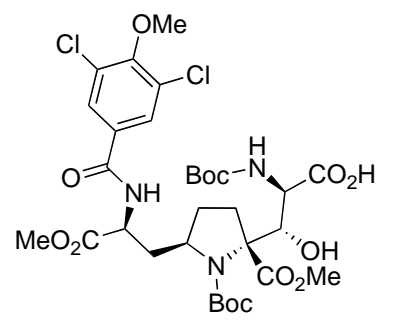

65 
Acid 65: To 46a (1.15 g, $1.43 \mathrm{mmol})$ was added $80 \%$ aqueous $\mathrm{AcOH}(20 \mathrm{~mL})$ and the resulting biphasic suspension was stirred vigorously. After $48 \mathrm{~h}$, consumption of starting material was observed by TLC analysis (50:50 EtOAc:hexanes). The reaction mixture was added slowly to a cooled $\left(0{ }^{\circ} \mathrm{C}\right)$ and vigorously stirred bi-phasic mixture of EtOAc $(20 \mathrm{~mL})$ and saturated $\mathrm{NaHCO}_{3}$ (100 mL). Once $\mathrm{CO}_{2}$ (g) evolution ceased, the bi-phasic mixture was warmed to room temperature and stirred for $1 \mathrm{~h}$. The organic layer was separated and the aqueous layer was extracted with EtOAc $(2 \times 50 \mathrm{~mL})$. The combined organic extracts were washed with brine $(50$ $\mathrm{mL})$, dried over $\mathrm{MgSO}_{4}$, and concentrated in vacuo to give the product $64(1.03 \mathrm{~g}, 100 \%)$ as a white solid, which was taken on to the next step without further purification.

To a solution of $64(1.03 \mathrm{~g}, 1.43 \mathrm{mmol})$ in $\mathrm{CH}_{3} \mathrm{CN}(25.0 \mathrm{~mL})$ and $\mathrm{pH} 6.7$ buffer $(25 \mathrm{~mL})$ was added TEMPO (0.065 g, $0.416 \mathrm{mmol}, 29 \mathrm{~mol} \%)$. The reaction mixture was heated $\left(60{ }^{\circ} \mathrm{C}\right)$ in an oil bath and a solution of $\mathrm{NaClO}_{2}(0.335 \mathrm{~g}, 3.15 \mathrm{mmol}, 85 \%$ pure $)$ and CHLOROX bleach $(0.600 \mathrm{~mL}, 0.462 \mathrm{mmol}, 32 \mathrm{~mol} \%,[\mathrm{NaOCl}] 5.25 \%$ by content or $\sim 0.71 \mathrm{M})$ in $\mathrm{H}_{2} \mathrm{O}(7 \mathrm{~mL})$ was added slowly over $15-20 \mathrm{~min}$. The mixture was stirred at $60{ }^{\circ} \mathrm{C}$ until starting material was consumed (26 h), as judged by TLC (100:0 EtOAc:hexanes). The reaction mixture was allowed to cool to $25{ }^{\circ} \mathrm{C}$ and $\mathrm{H}_{2} \mathrm{O}(30 \mathrm{~mL})$ and EtOAc $(50 \mathrm{~mL})$ were added. The organic layer was separated and the aqueous layer was cooled $\left(0{ }^{\circ} \mathrm{C}\right)$, acidified to $\mathrm{pH} 2$ with $1.0 \mathrm{~N} \mathrm{HCl}$, and extracted with EtOAc $(3 \times 50 \mathrm{~mL})$. The combined orange organic extracts were washed with saturated aqueous $\mathrm{Na}_{2} \mathrm{~S}_{2} \mathrm{O}_{3}(10 \mathrm{~mL})$, brine $(25 \mathrm{~mL})$, dried over $\mathrm{Na}_{2} \mathrm{SO}_{4}$, and concentrated in vacuo to give white foam. The foam was purified by flash chromatography (gradient elution 100:0 - 98:2 EtOAc:AcOH) to yield 65 as a white solid $(0.930 \mathrm{~g}, 89 \%$ from 46a): $\mathrm{mp}=130-135$ ${ }^{\circ} \mathrm{C} ;{ }^{1} \mathrm{H}$ NMR $\left(500 \mathrm{MHz}, \mathrm{DMSO}-d_{6}, 375 \mathrm{~K}\right) \delta 8.67(\mathrm{~d}, J=7.4,1 \mathrm{H}), 7.95(\mathrm{~s}, 2 \mathrm{H}), 6.39(\mathrm{~d}, J=7.9$, $1 \mathrm{H}), 4.54(\operatorname{app} \mathrm{dd}, J=14.2,7.3,1 \mathrm{H}), 4.39(\mathrm{~d}, J=6.9,1 \mathrm{H}), 4.24(\mathrm{dd}, J=9.2,7.0,1 \mathrm{H}), 4.01-3.95$ 
(m, 1H), $3.93(\mathrm{~s}, 3 \mathrm{H}), 3.69(\mathrm{~s}, 3 \mathrm{H}), 3.68(\mathrm{~s}, 3 \mathrm{H}), 2.48-2.40(\mathrm{~m}, 2 \mathrm{H}), 2.19(\mathrm{ddd}, J=13.5,11.8$, 7.7, 1H), 2.05 (dddd, $J=11.8,11.8,7.9,7.9,1 \mathrm{H}), 1.84(\mathrm{ddd}, J=13.9,9.6,7.6,1 \mathrm{H}), 1.68-1.64$ $(\mathrm{m}, 1 \mathrm{H}), 1.47(\mathrm{~s}, 9 \mathrm{H}), 1.39(\mathrm{~s}, 9 \mathrm{H})$ [Note: The $\mathrm{OH}$ from the acid and alcohol was not observed in the ${ }^{1} \mathrm{H}$ NMR.]; ${ }^{13} \mathrm{C}$ NMR (125 MHz, $\mathrm{CD}_{3} \mathrm{CN}$, only major rotamer reported at $\left.298 \mathrm{~K}\right) \delta 173.3$, $172.9,172.2,165.1,157.1,156.2,155.8,131.9,130.2,129.1,82.8,80.4,75.7,74.1,61.5,60.6$, 56.6, 53.2, 53.0, 52.8, 35.2, 34.8, 28.5, 28.4, 27.7; IR (thin film) 3302, 3078, 3006, 2978, 2935, 1744, 1723, 1669, 1592, 1551, 1477, 1394, 1368, 1256, $1165 \mathrm{~cm}^{-1}$; HRMS (ESI/methanol) $\mathrm{m} / \mathrm{z}$ calcd for $\mathrm{C}_{31} \mathrm{H}_{43} \mathrm{Cl}_{2} \mathrm{~N}_{3} \mathrm{O}_{13}(\mathrm{M}+\mathrm{Na})^{+} 758.2071$, found 758.2056; $[\alpha]^{25}{ }_{\mathrm{D}}-6.2\left(c 0.46, \mathrm{CHCl}_{3}\right)$.
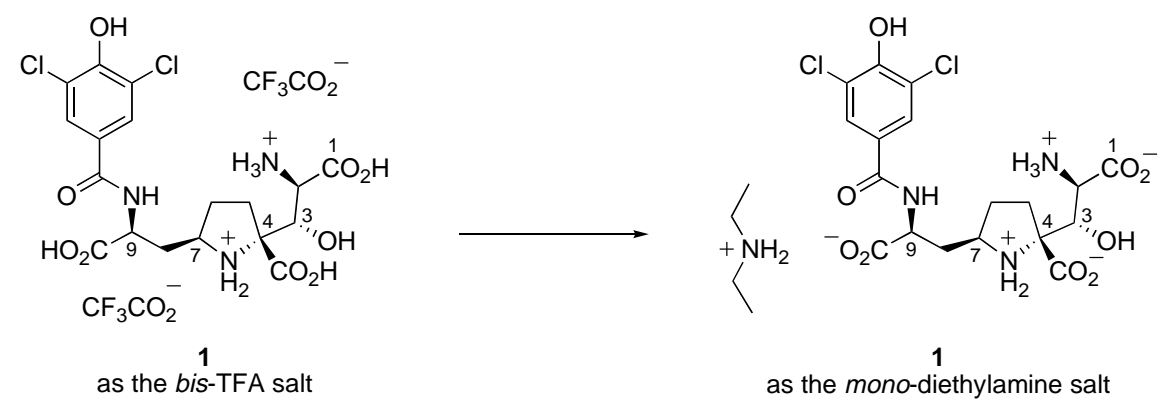

Mono-Diethylamine 1: To a solution of $1(1.00 \mathrm{mg}, 0.001 \mathrm{mmol})$ in $\mathrm{H}_{2} \mathrm{O}(1 \mathrm{~mL})$ was added aqueous $\mathrm{pH} 7.0 \mathrm{Et}_{2} \mathrm{NH} / \mathrm{CO}_{2}\left(15 \mathrm{~mL}, 2.0 \mathrm{mM}\right.$ in $\left.\mathrm{H}_{2} \mathrm{O}\right)$. The resulting neutral solution was lyophilized to provide a white solid. ${ }^{1} \mathrm{H}$ NMR $\left(500 \mathrm{MHz}, \mathrm{D}_{2} \mathrm{O}\right.$, calibrated to $\mathrm{H}_{2} \mathrm{O}$ at $\left.4.69 \mathrm{ppm}\right) \delta$ $7.62(\mathrm{~s}, 2 \mathrm{H}), 4.40(\mathrm{~s}, 1 \mathrm{H}), 4.34(\mathrm{dd}, J=8.5,5.3,1 \mathrm{H}), 4.15(\mathrm{~s}, 1 \mathrm{H}), 3.73-3.66(\mathrm{~m}, 2 \mathrm{H}), 2.95(\mathrm{q}, J$ $=7.3,4 \mathrm{H}), 2.43(\mathrm{ddd}, J=14.3,6.1,6.1,1 \mathrm{H}), 2.31-2.26(\mathrm{~m}, 1 \mathrm{H}), 2.13-1.99(\mathrm{~m}, 3 \mathrm{H}), 1.64-1.56$ (m, 1H), $1.24(\mathrm{t}, J=7.3,6 \mathrm{H})$. (Only ${ }^{1} \mathrm{H}$ NMR was acquired for this compound)

\section{Notes and References}

(1) Pangborn, A. B.; Giardello, M. A.; Grubbs, R. H.; Rosen, R. K.; Timmers, F. J. Organometallics 1996, 15, 1518-1520.

(2) Armarego, W. L. F.; Chai, C. L. L. Purification of Laboratory Chemicals; Fifth ed.; Elsevier, 2003.

(3) Watson, S. C.; Eastham, J. F. J. Organomet. Chem. 1967, 9, 165-168. 
(4) Fadi, H.; Sylvie, R.; Gérard, R. Org. Synth. 2000, 77, 206.

(5) Shute, R. E.; Rich, D., H. Synthesis 1987, 4, 346-348.

(6) Jain, R. Org. Prep. Proced. Int. 2001, 33, 405-409.

(7) Collado, I.; Ezquerra, J.; Pedregal, C. J. Org. Chem. 1995, 60, 5011-5015.

(8) Zoller, U.; Ben-Ishai, D. Tetrahedron 1975, 31, 863-866.

(9) Schmidt, U.; Lieberknecht, A.; Wild, J. Synthesis 1984, 53-60.

(10) Coleman, R. S.; Carpenter, A. J. J. Org. Chem. 1993, 58, 4452-4461.

(11) Diaba, F.; Ricou, E.; Bonjoch, J. Tetrahedron: Asymmetry 2006, 17, 1437-1443.

\section{II. ${ }^{1} \mathrm{H}$ NMR and ${ }^{13} \mathrm{C}$ NMR Spectra for Compounds}




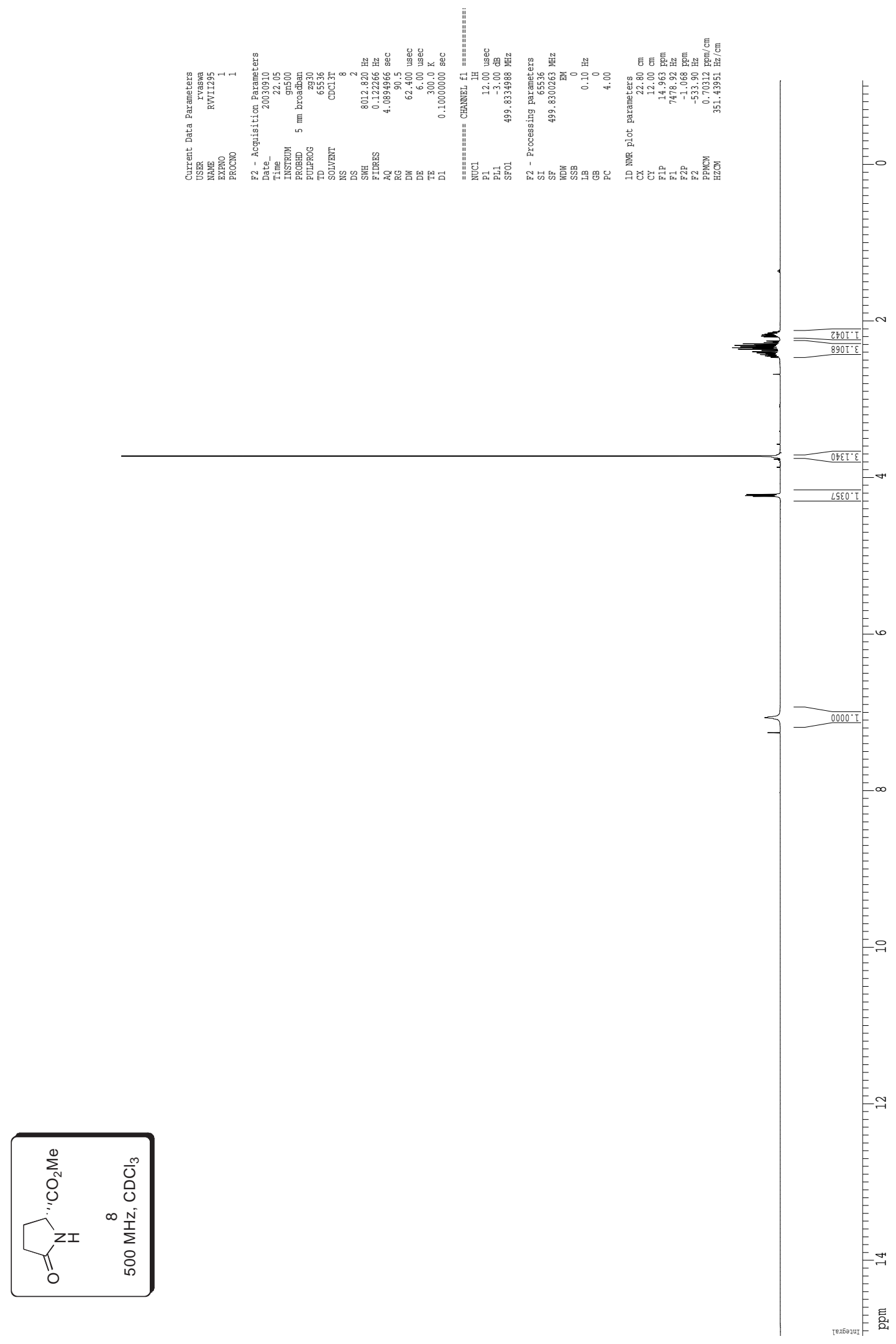



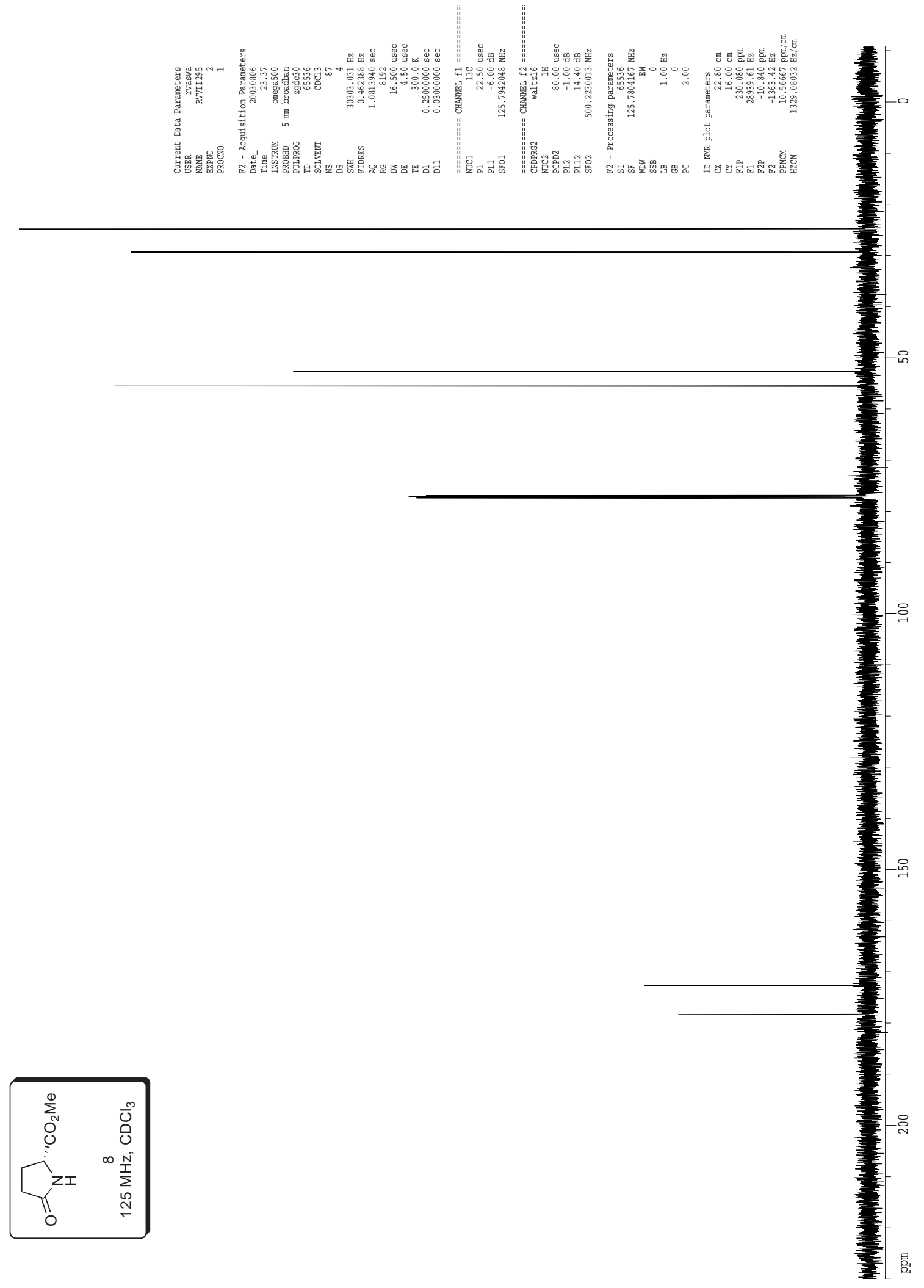


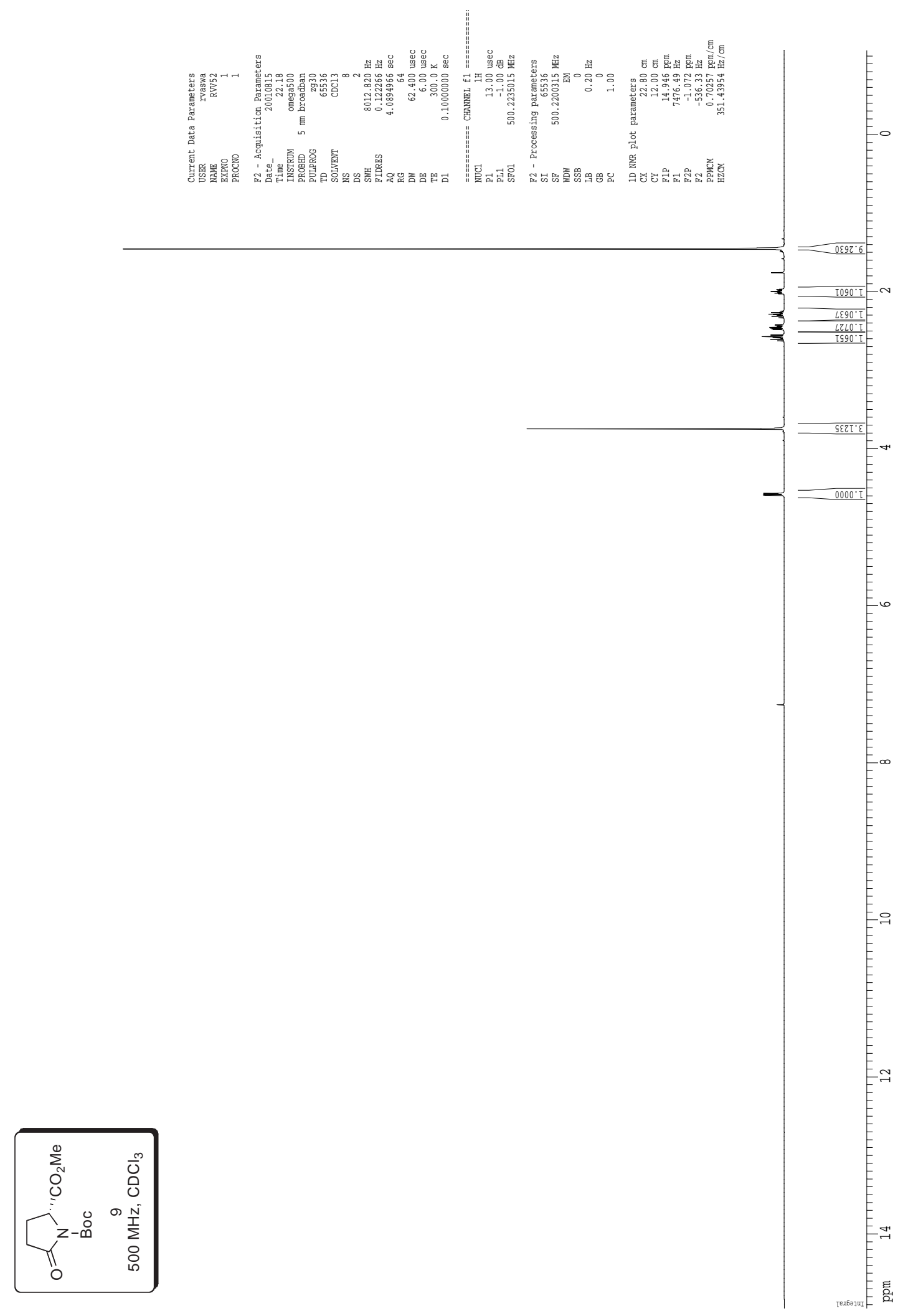



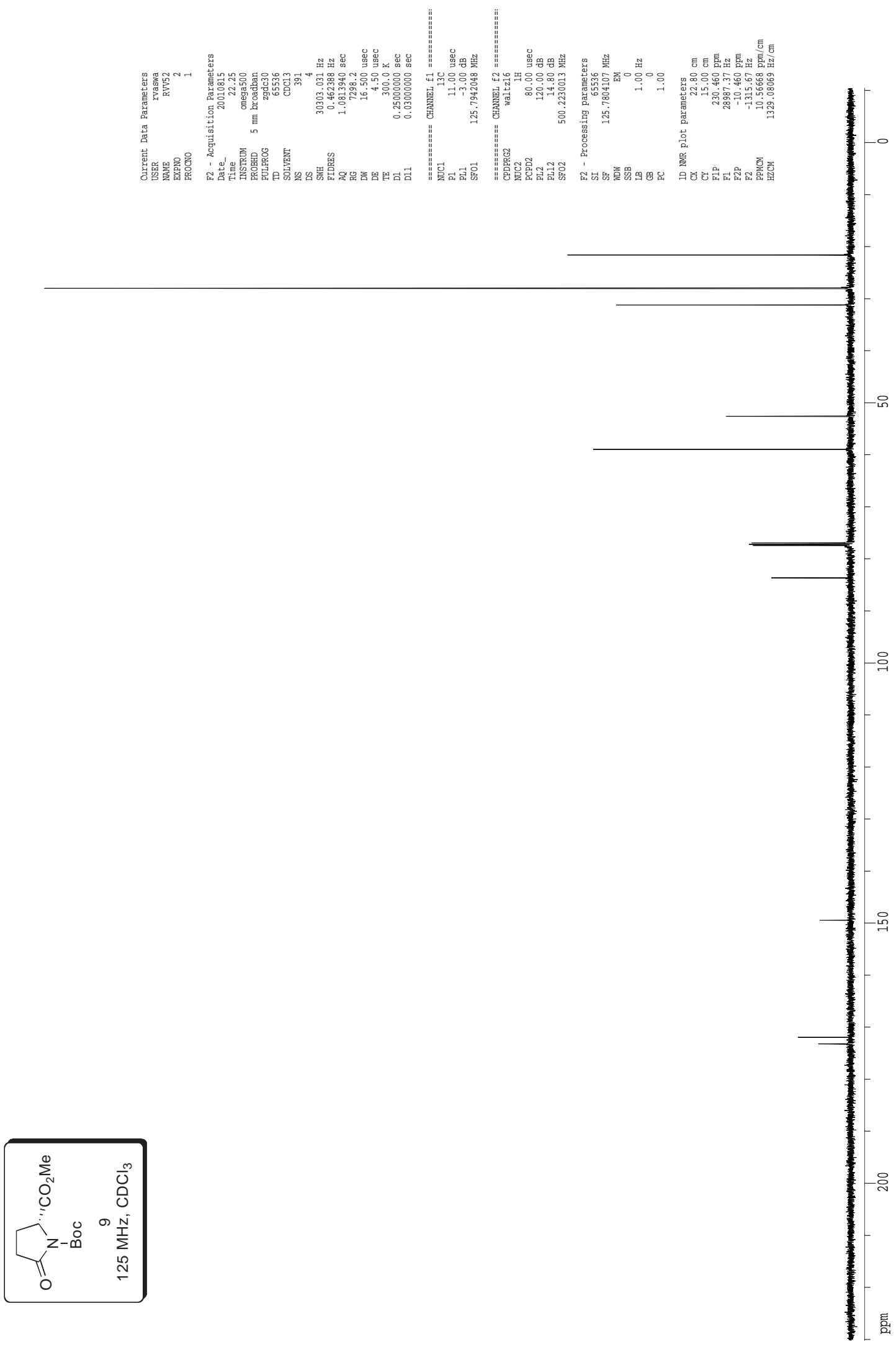


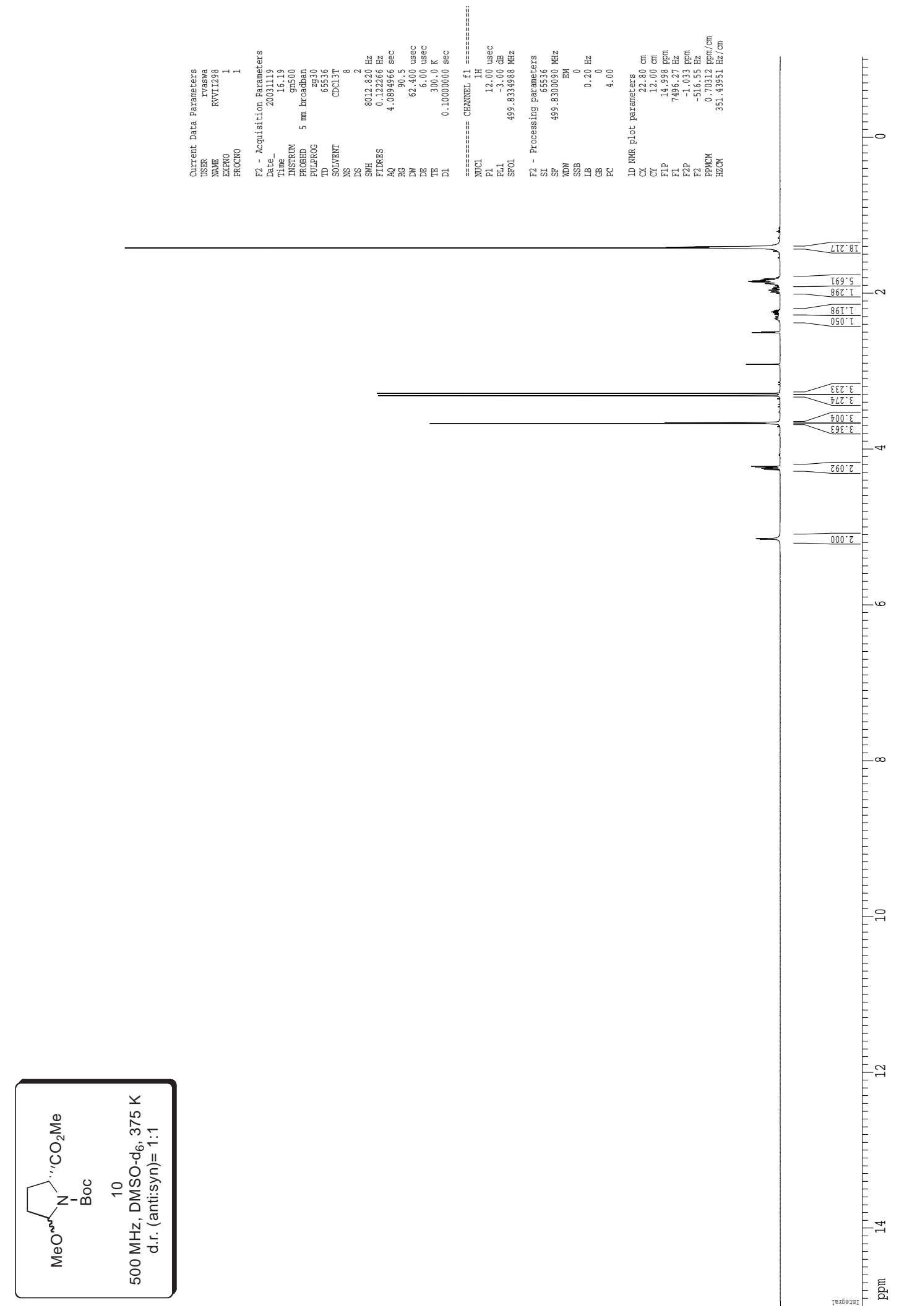



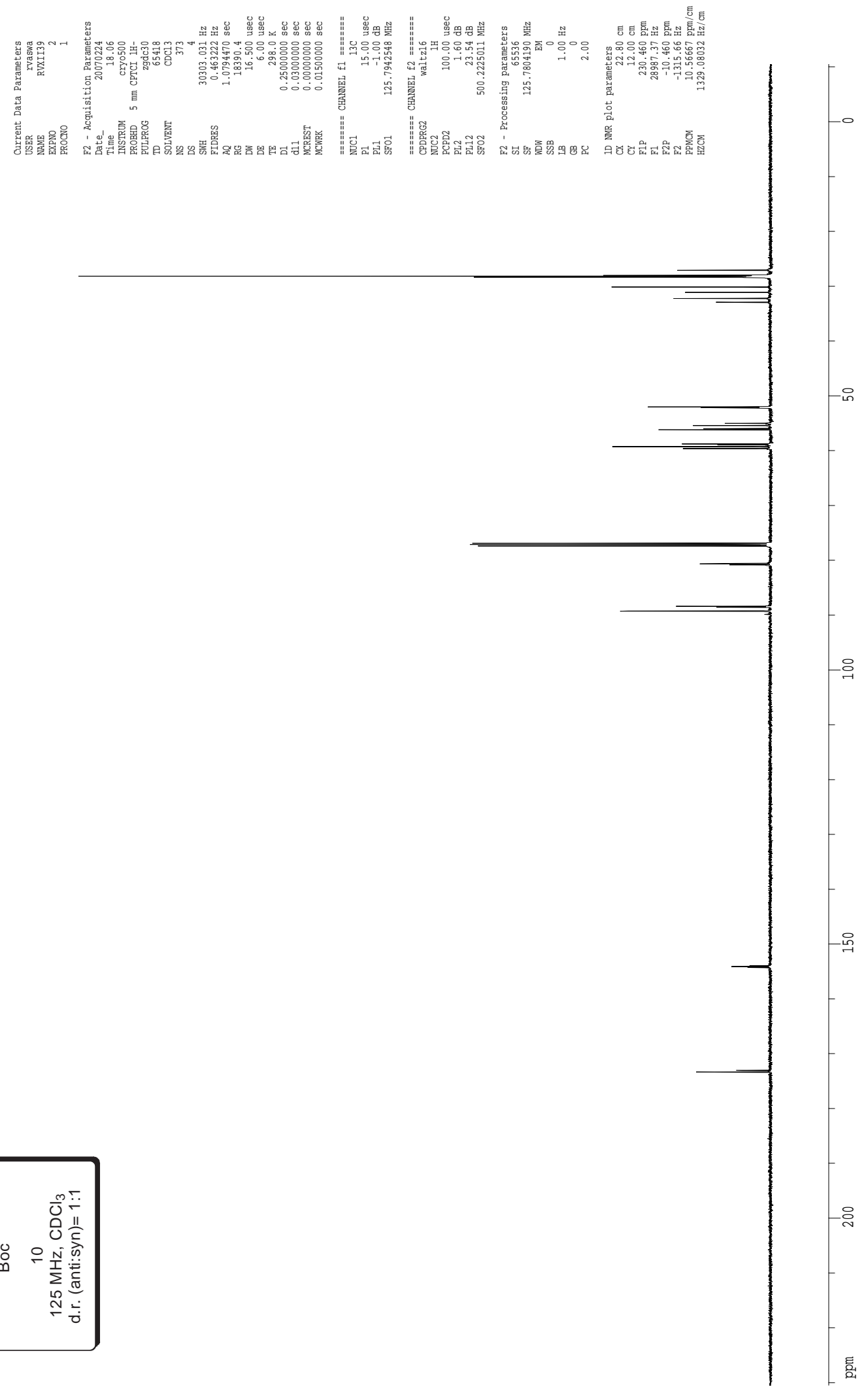

S45 

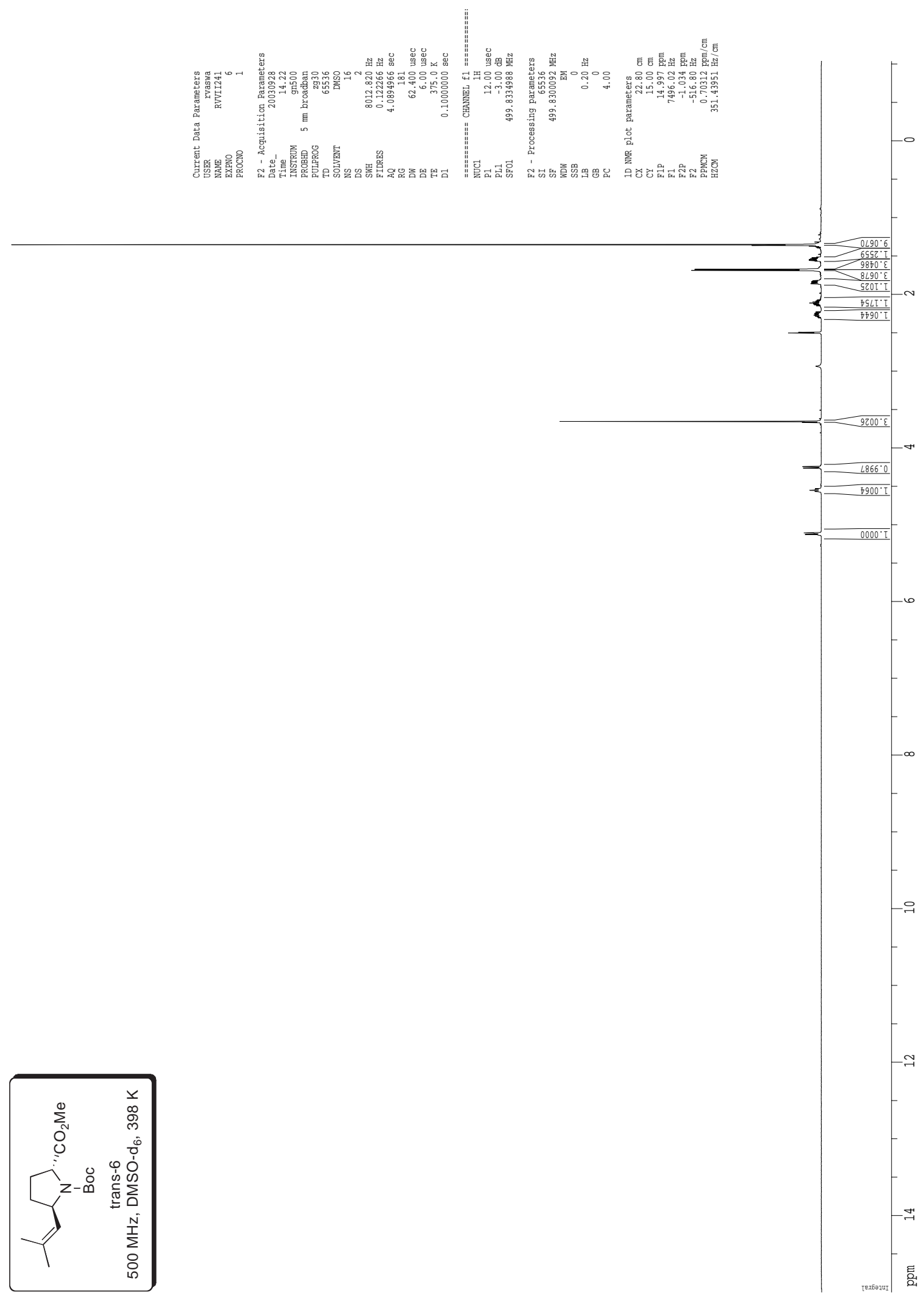

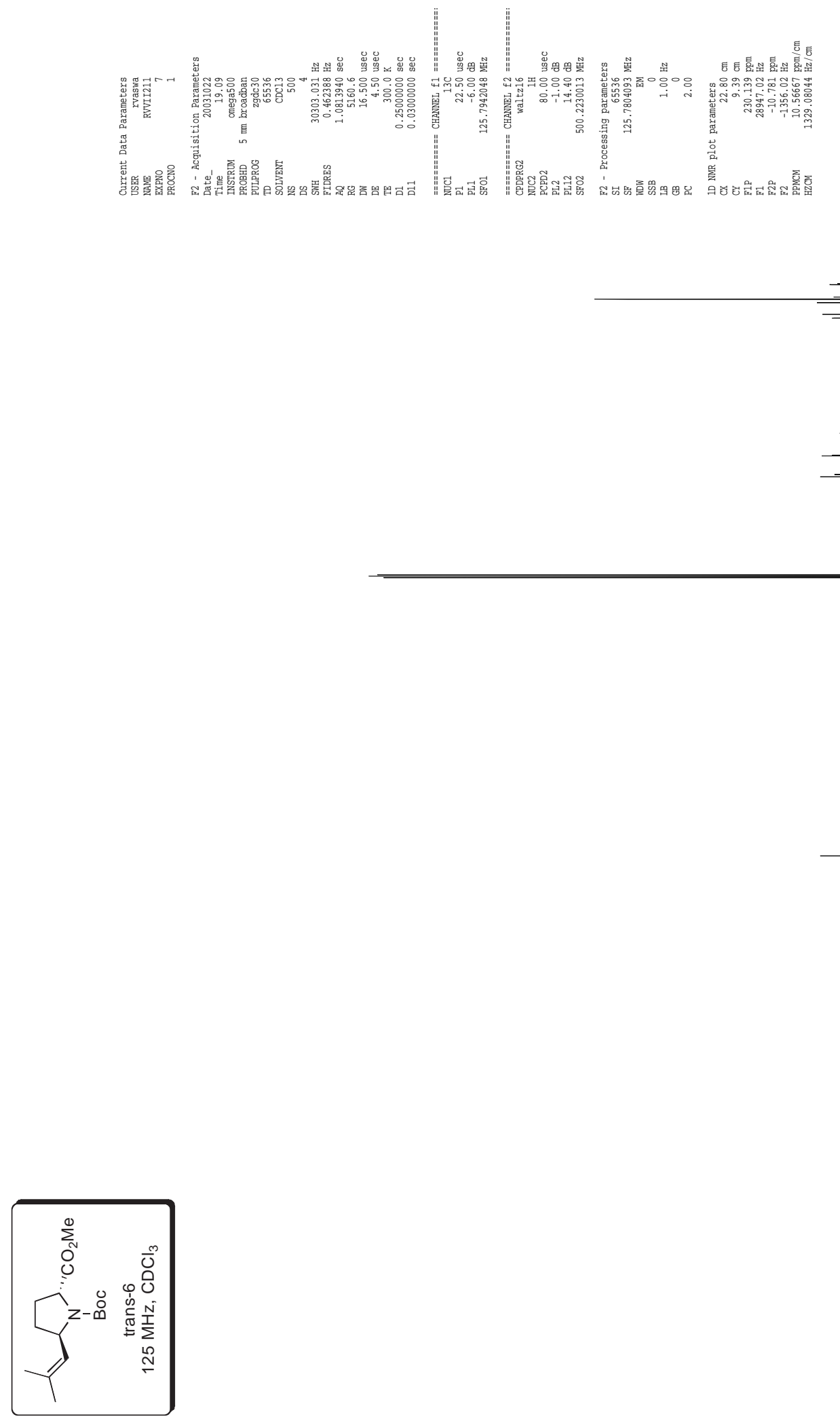


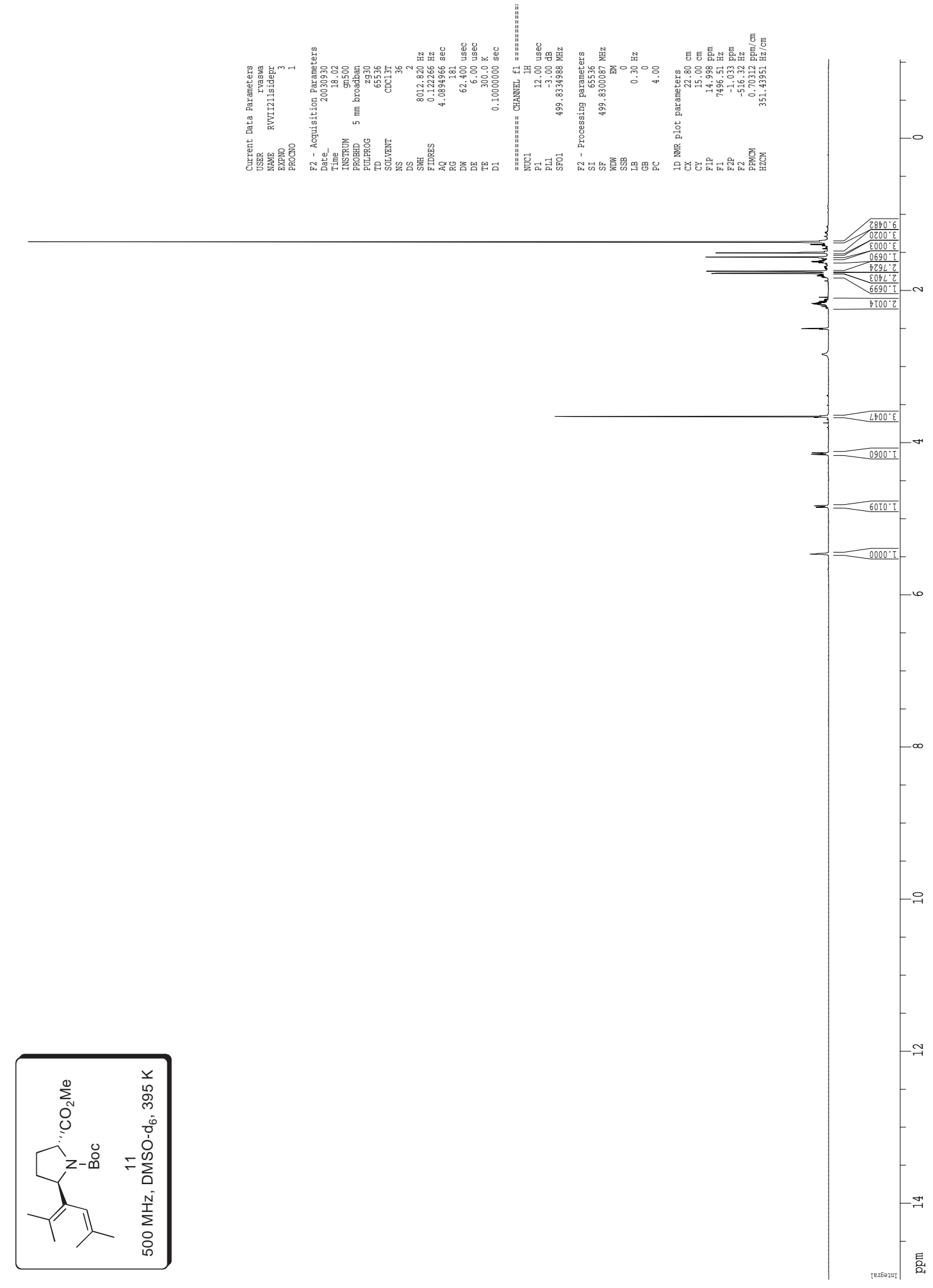



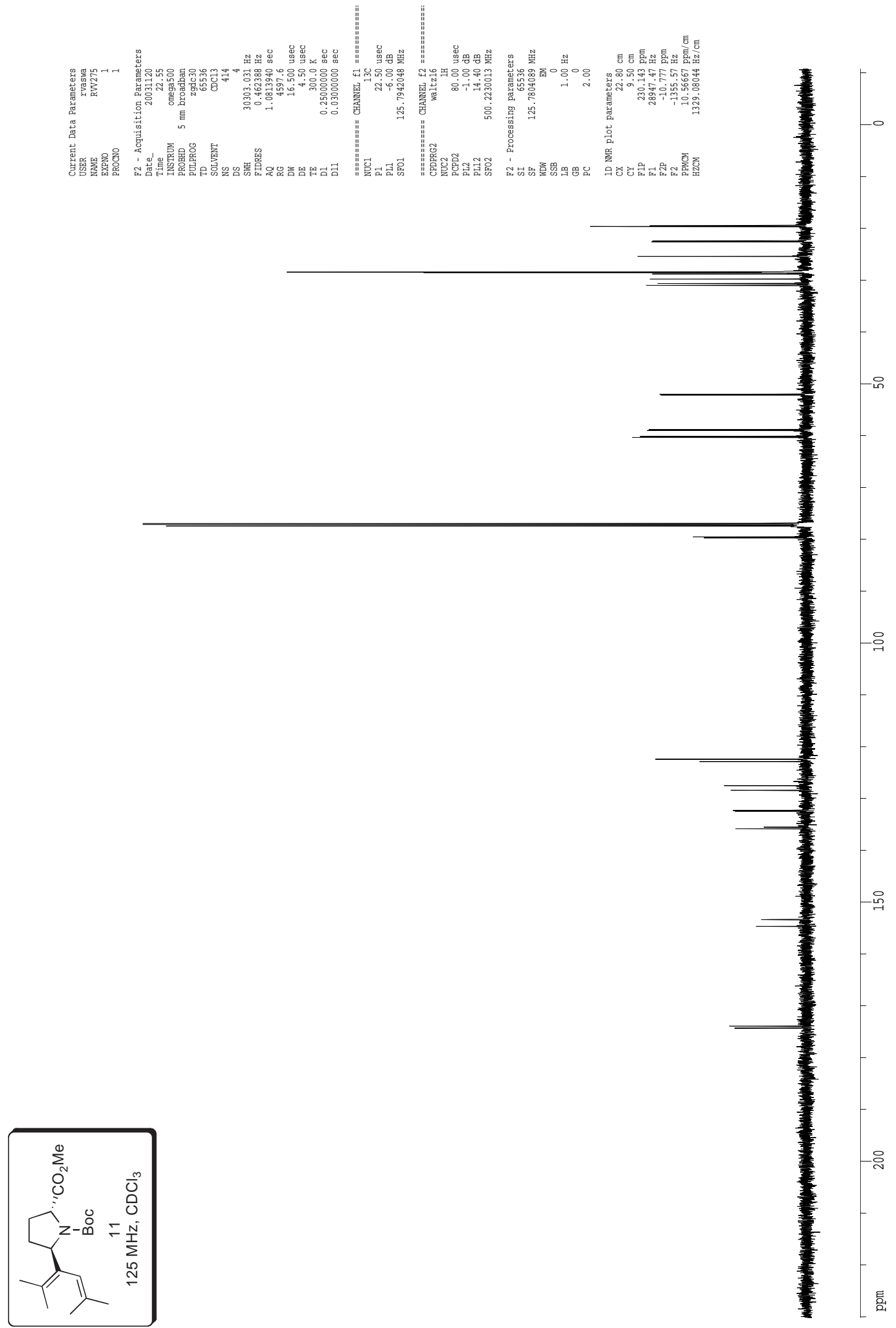

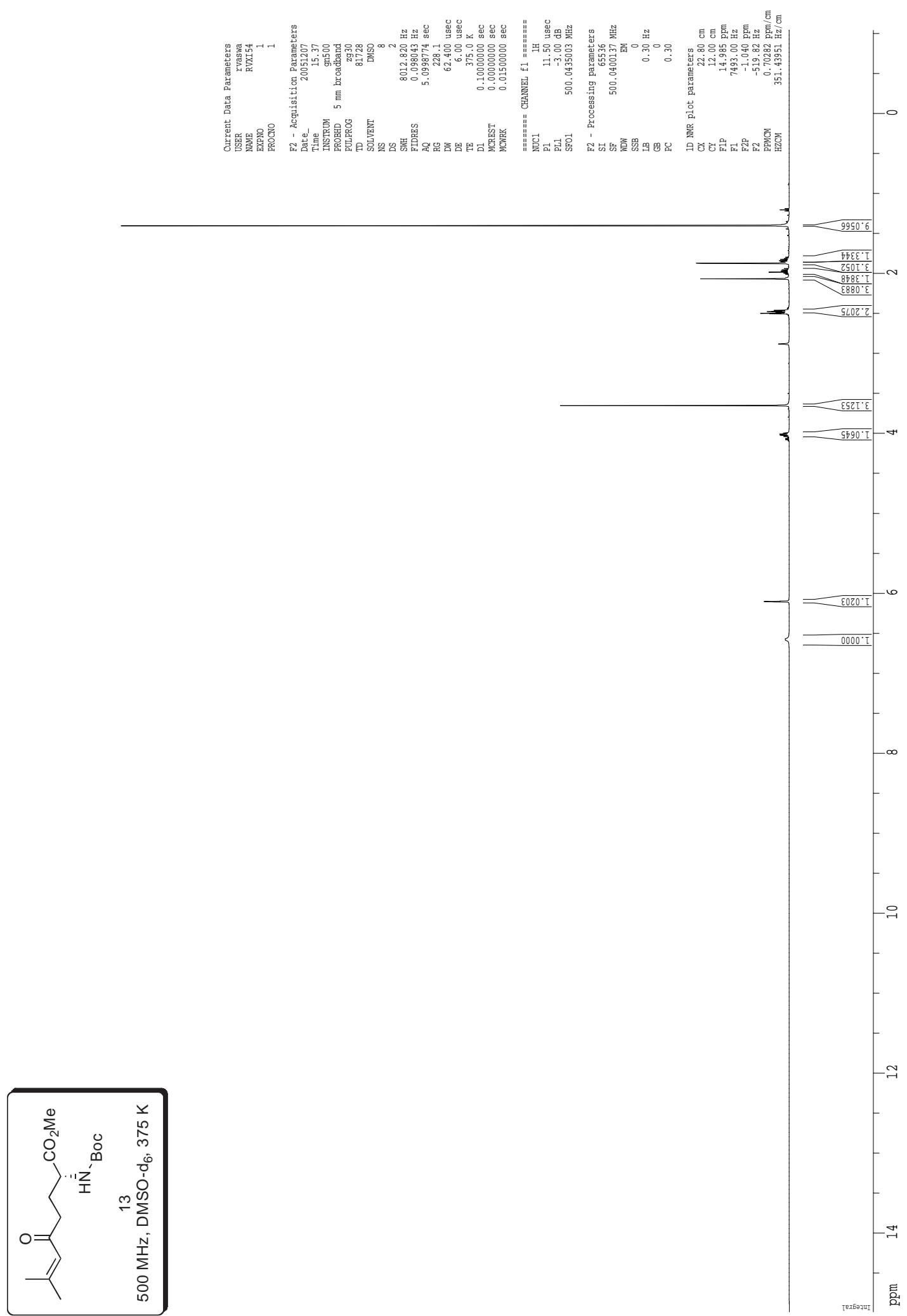


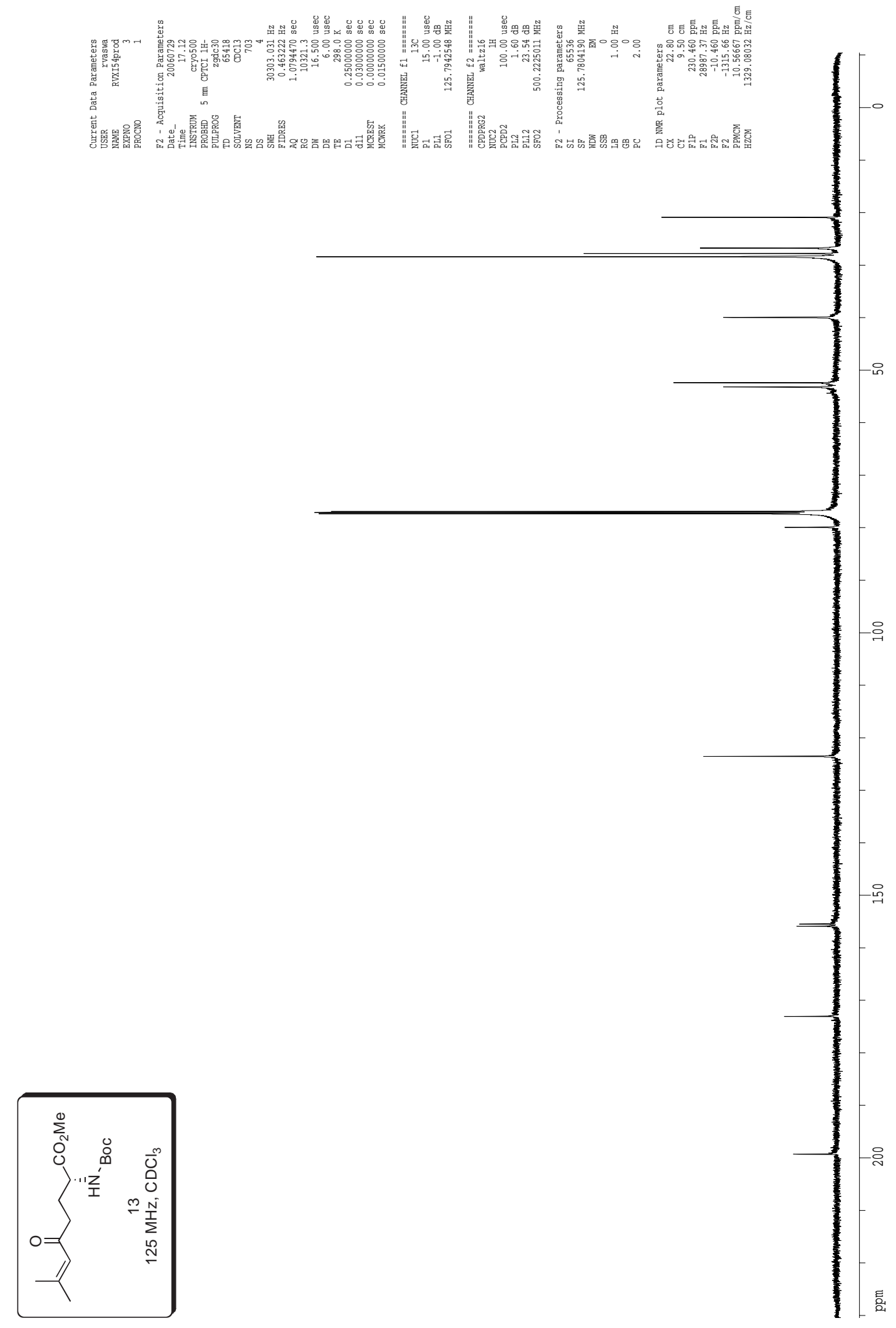



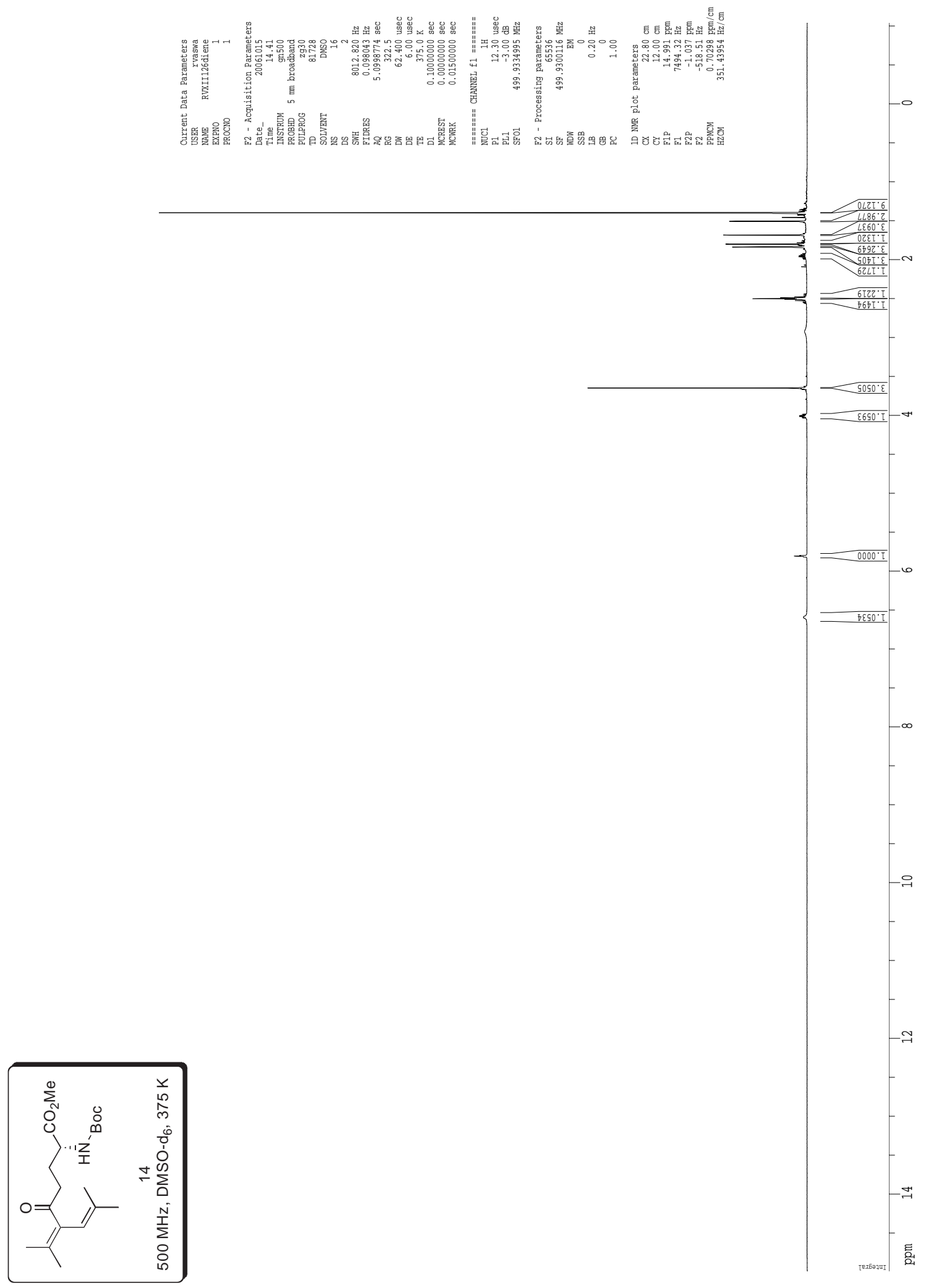

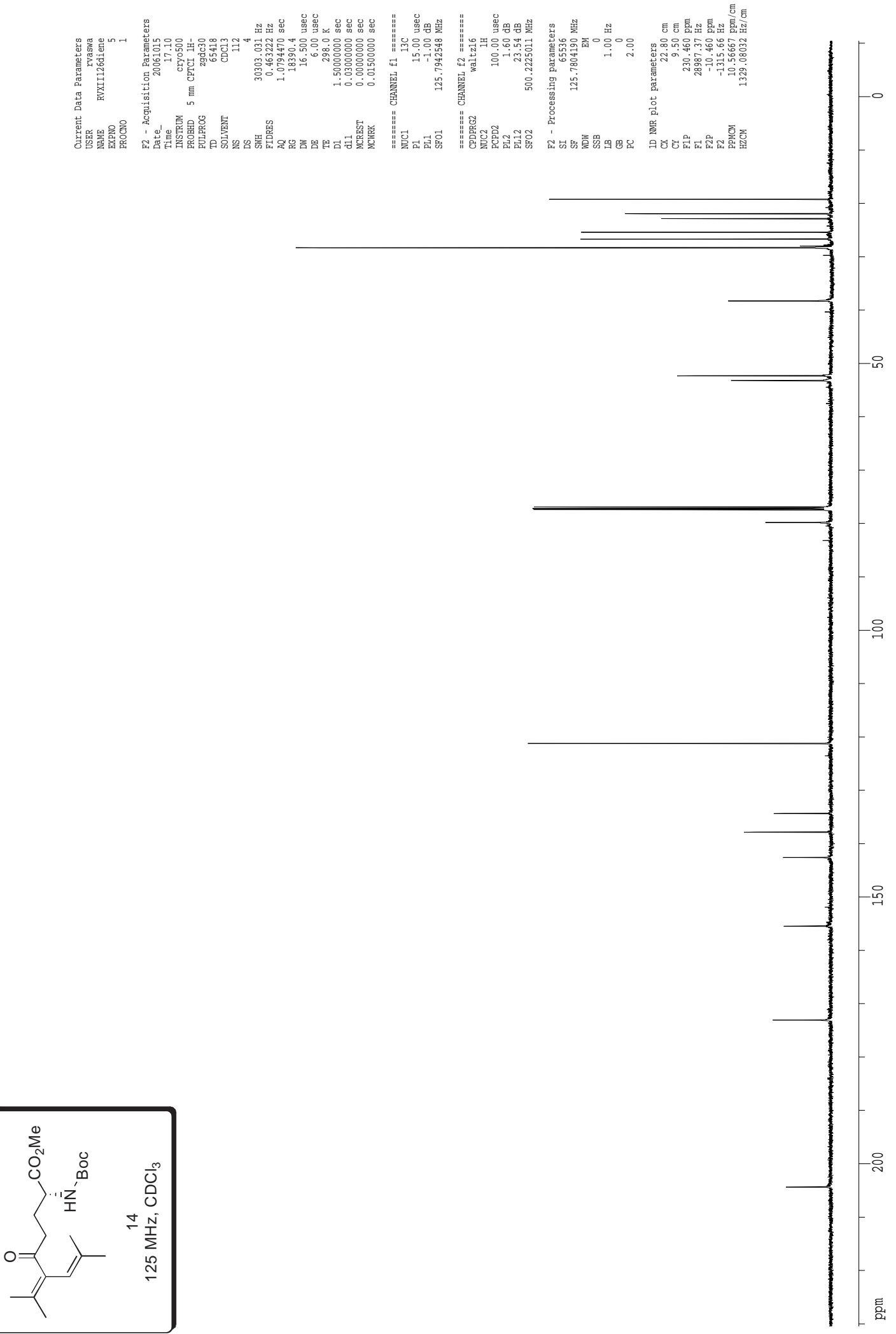

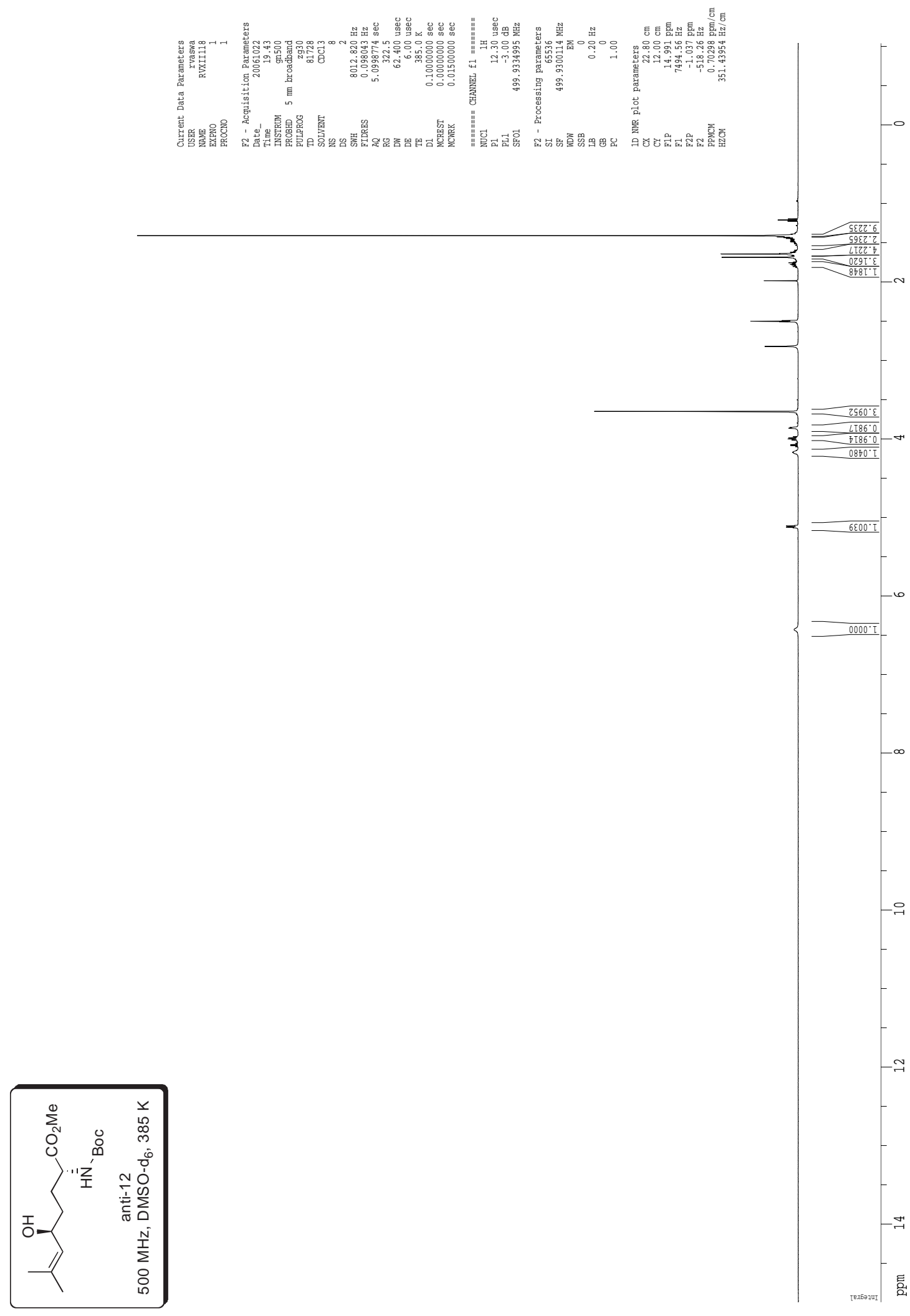


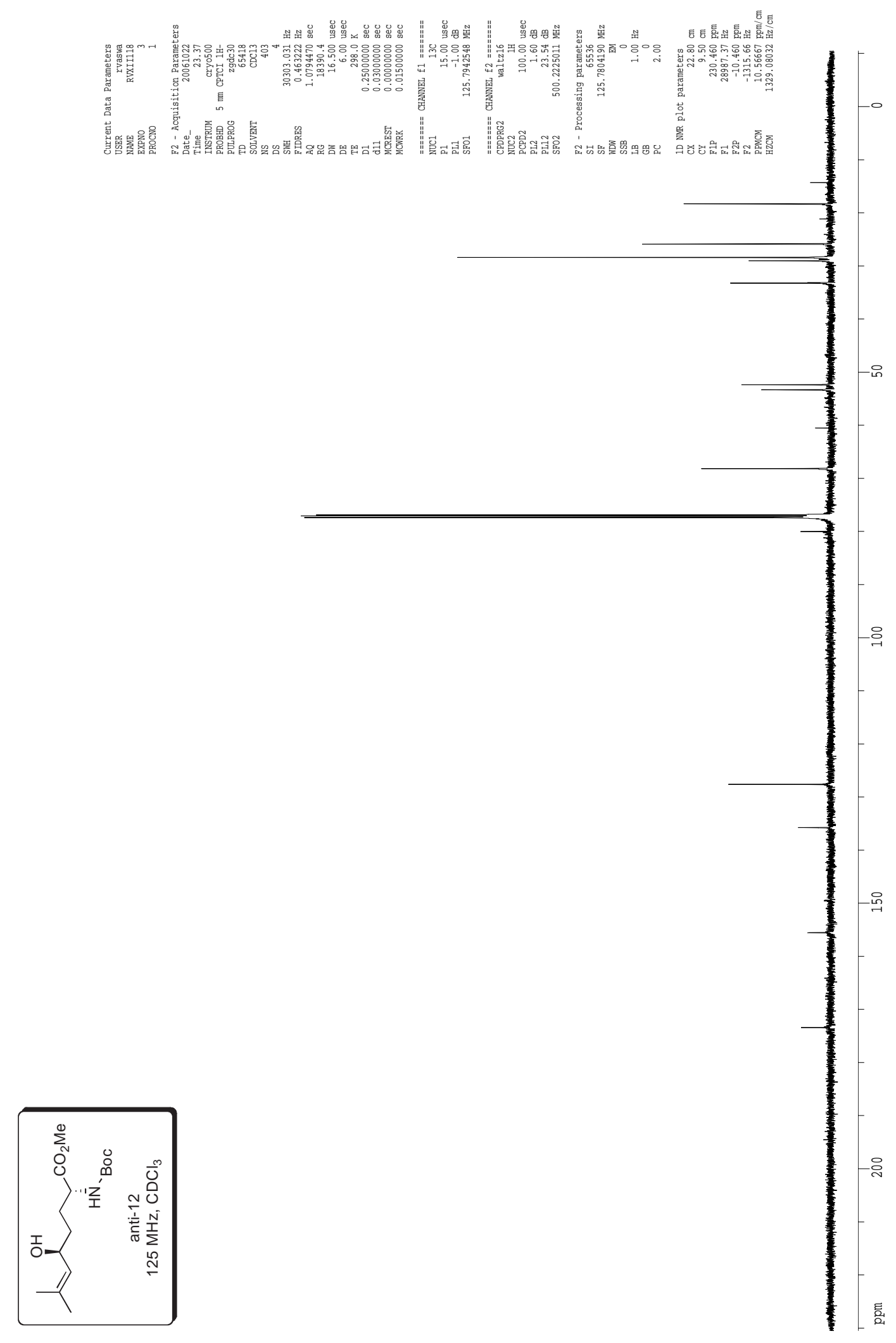

S55 


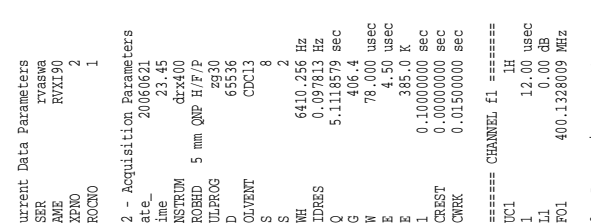

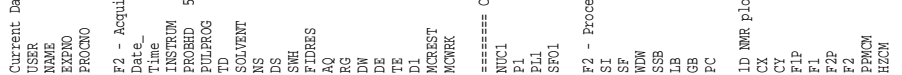

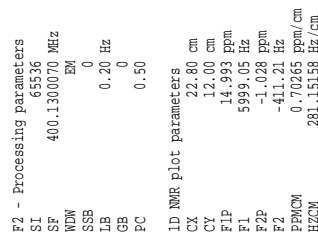

-

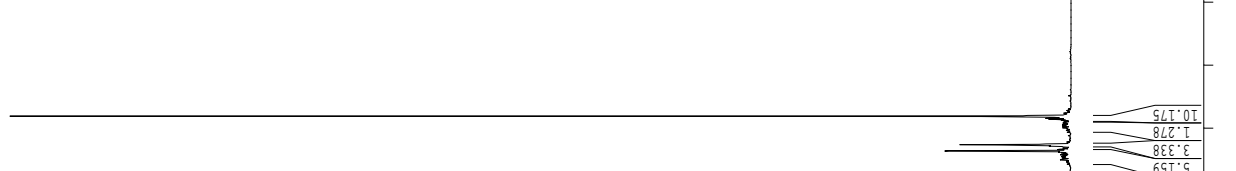

$-\mathrm{N}$

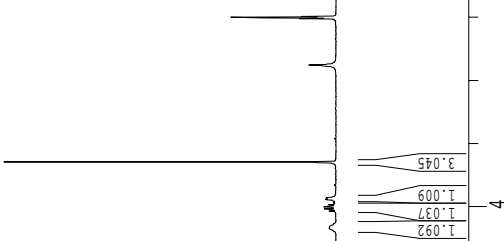

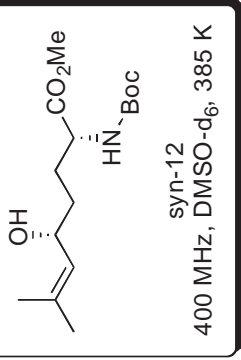



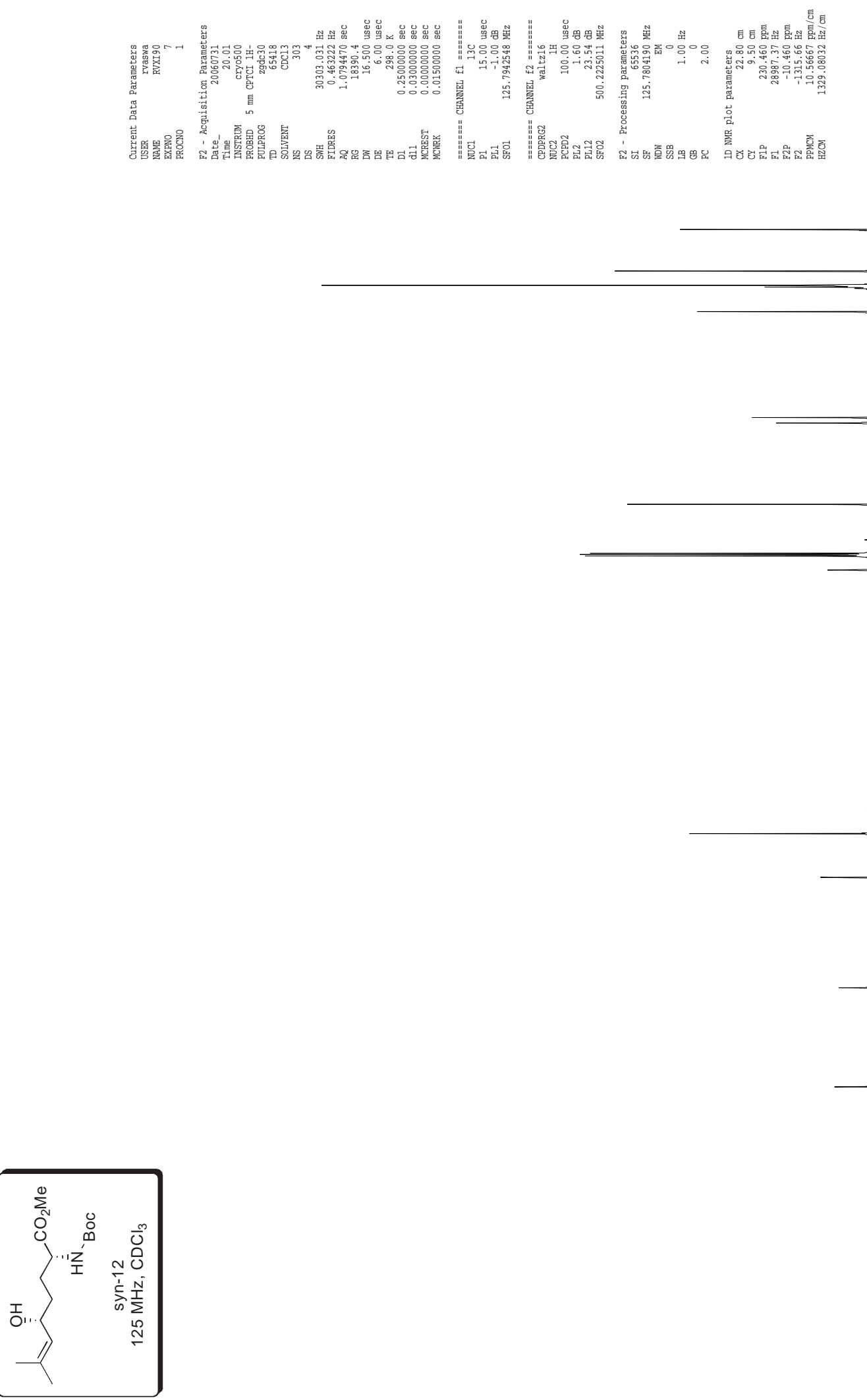


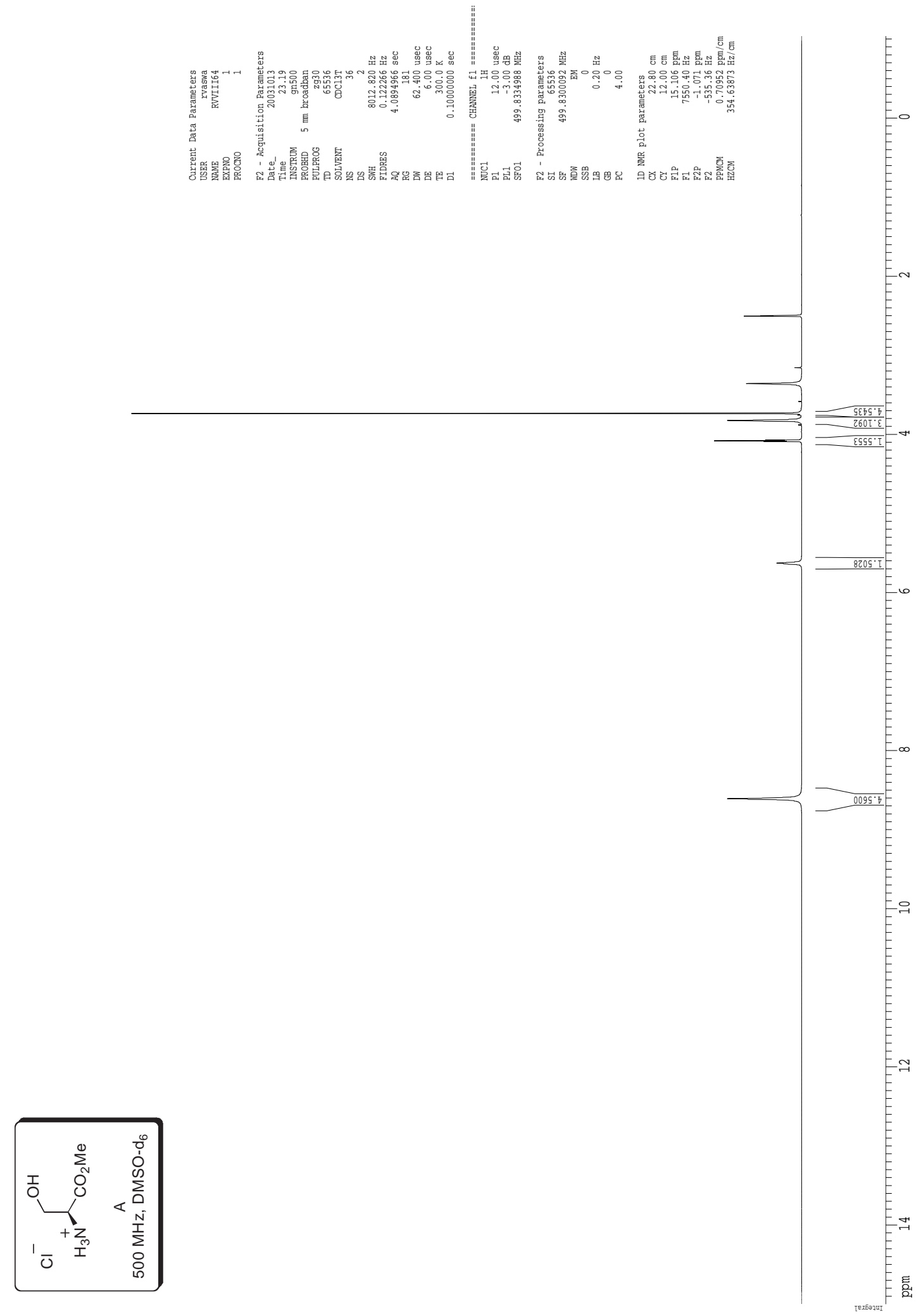



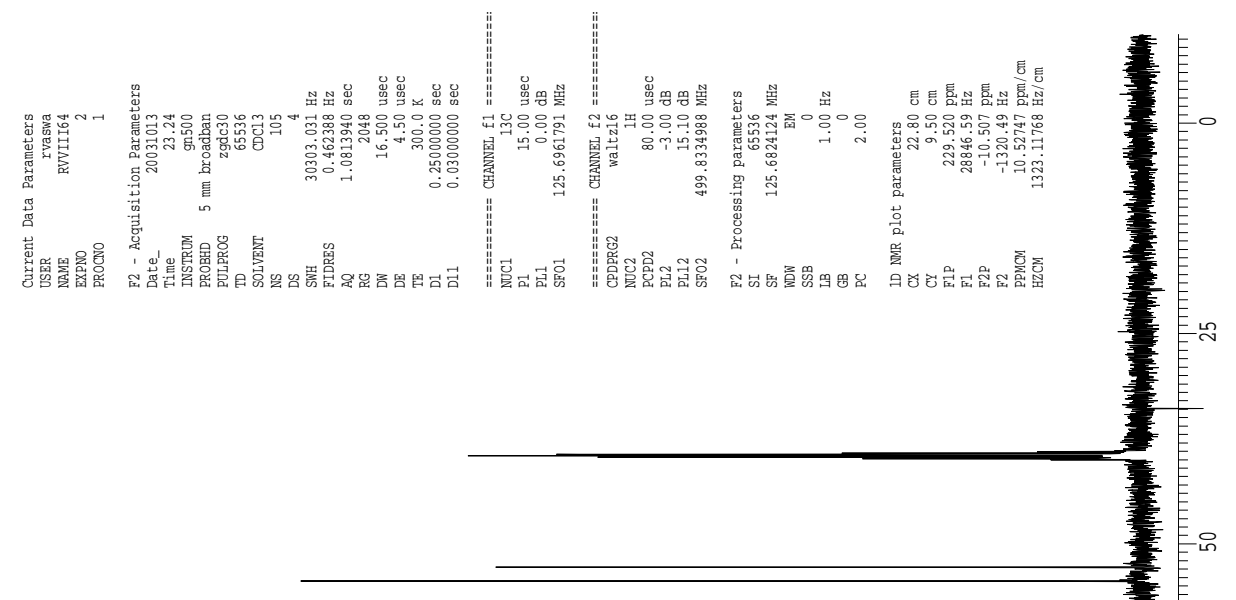

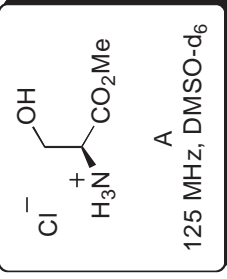




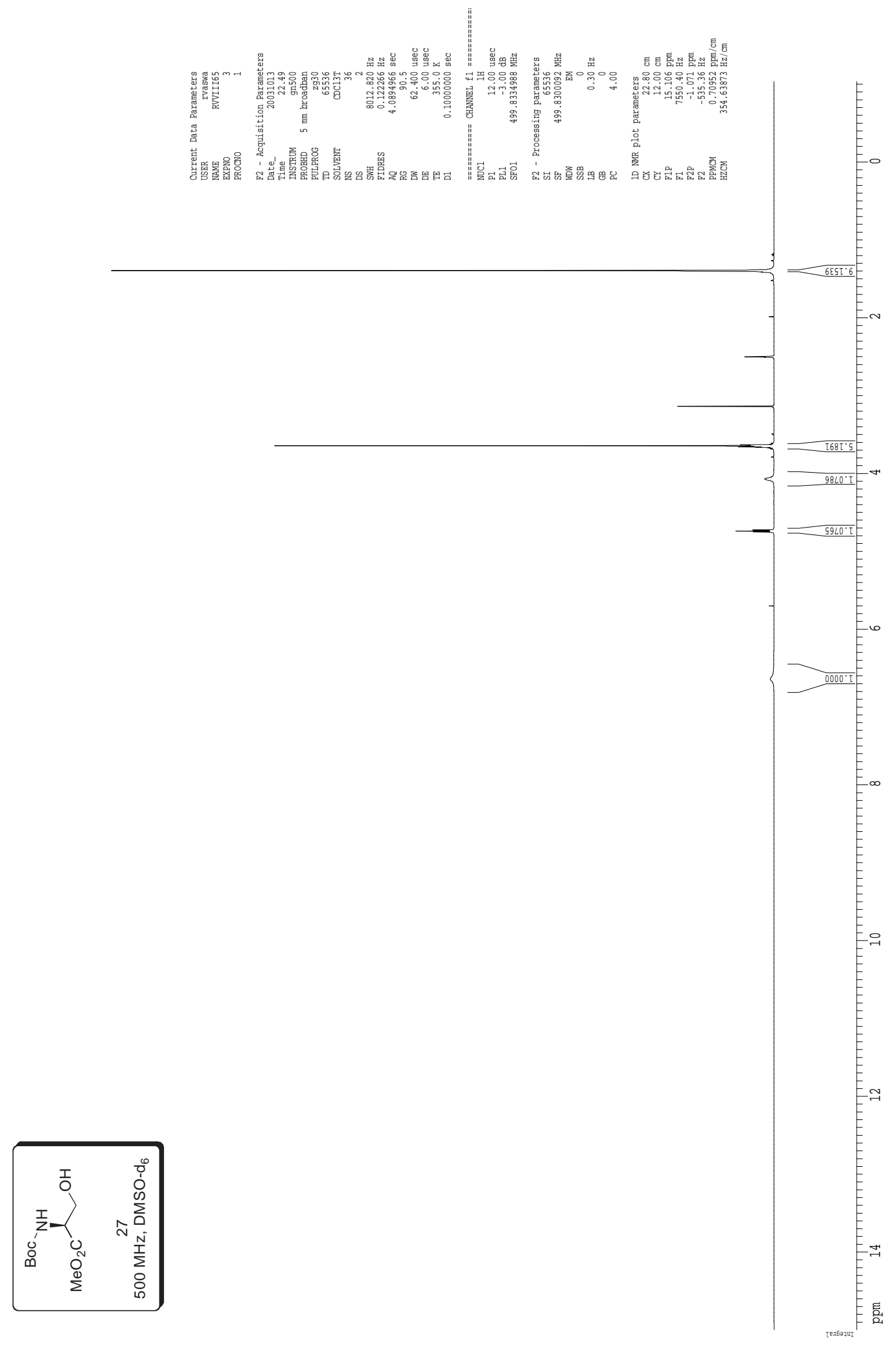



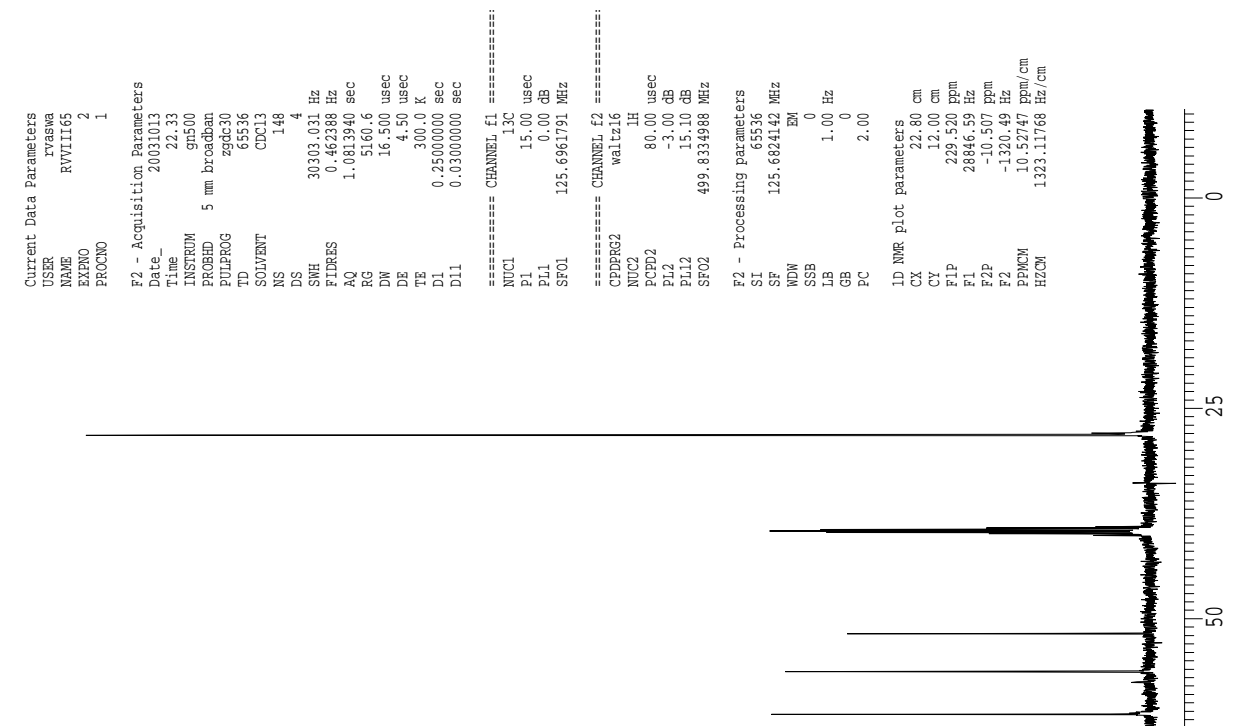

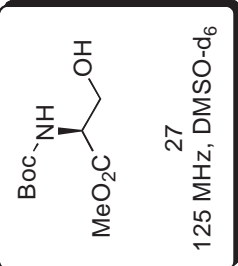




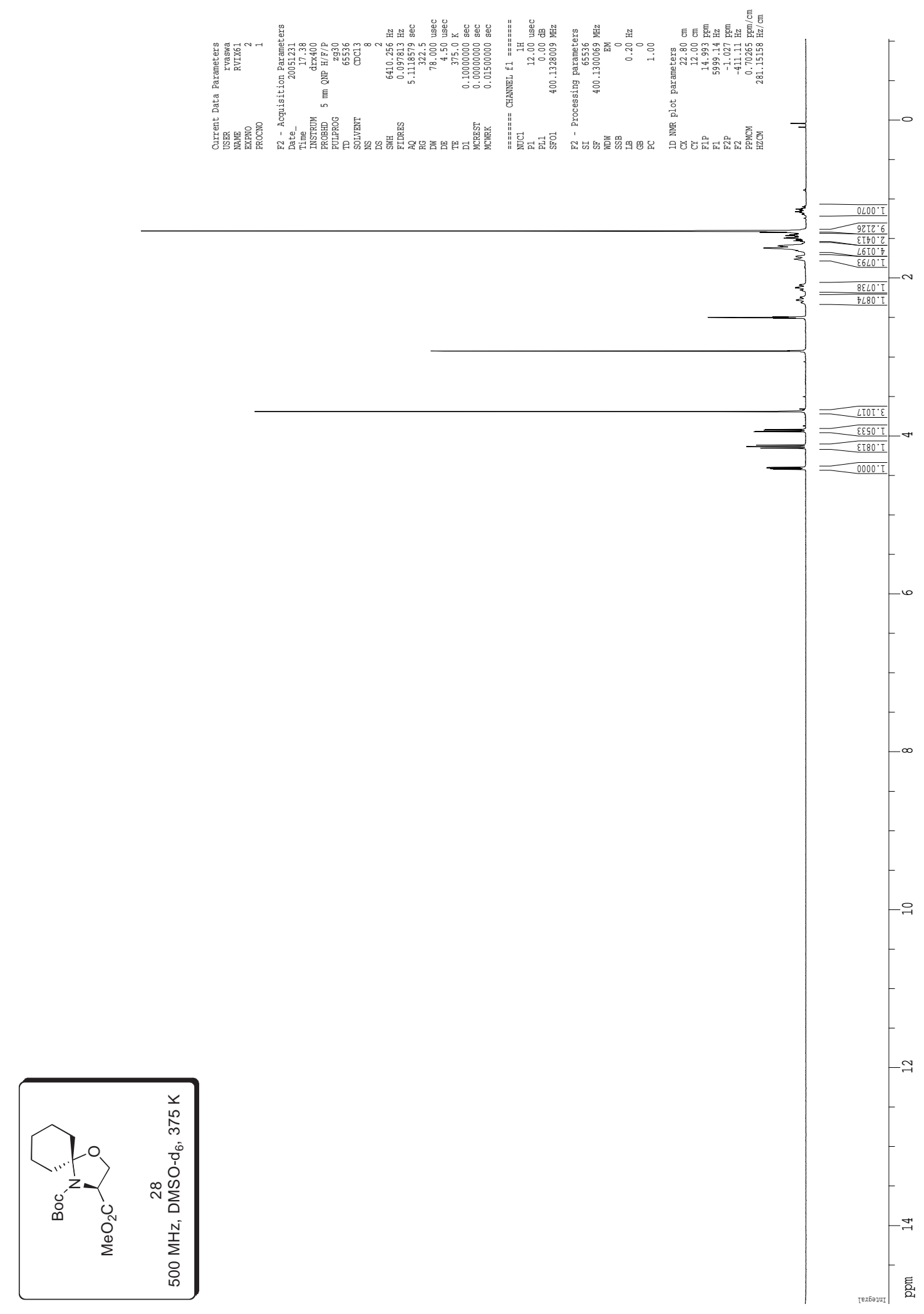



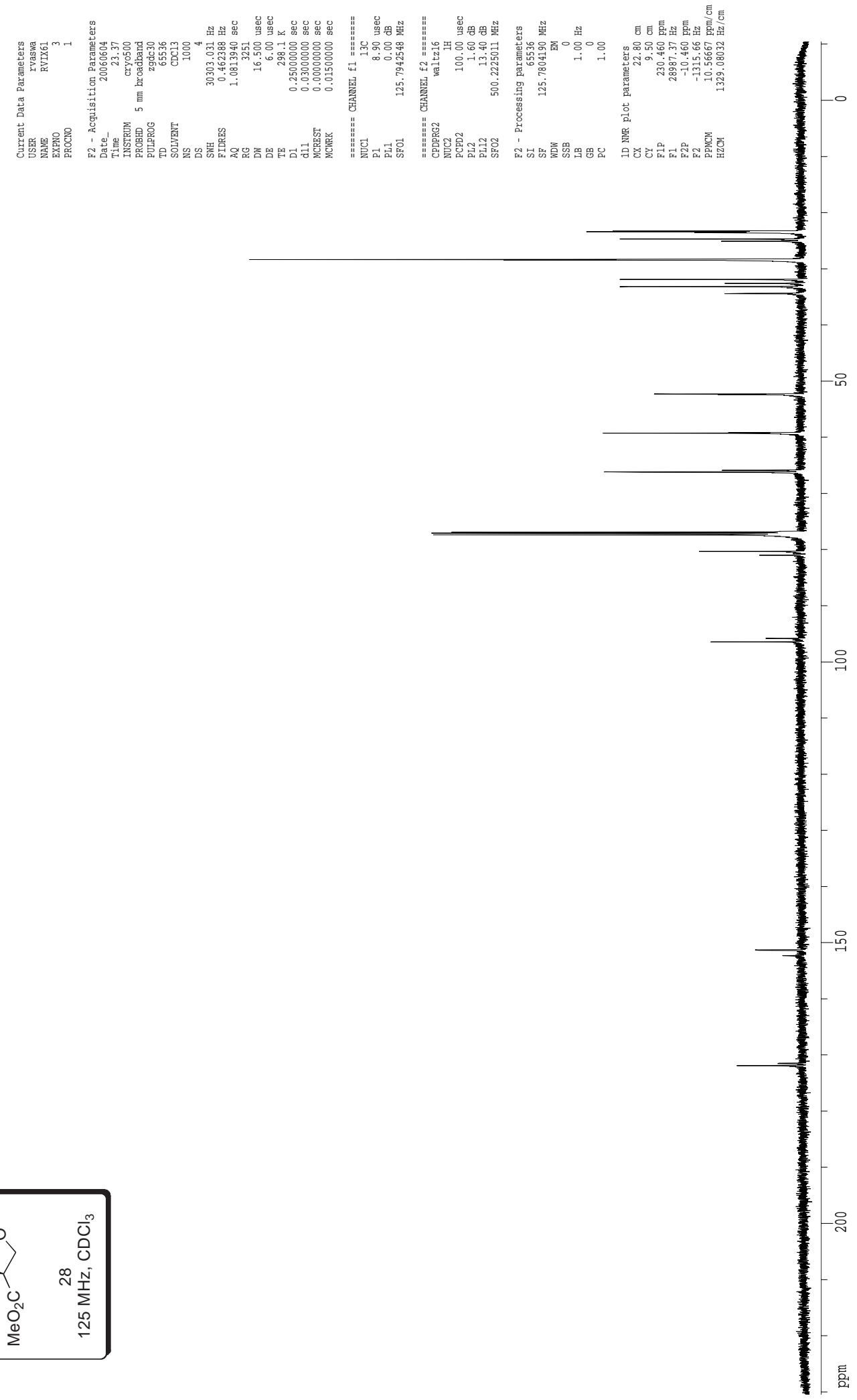


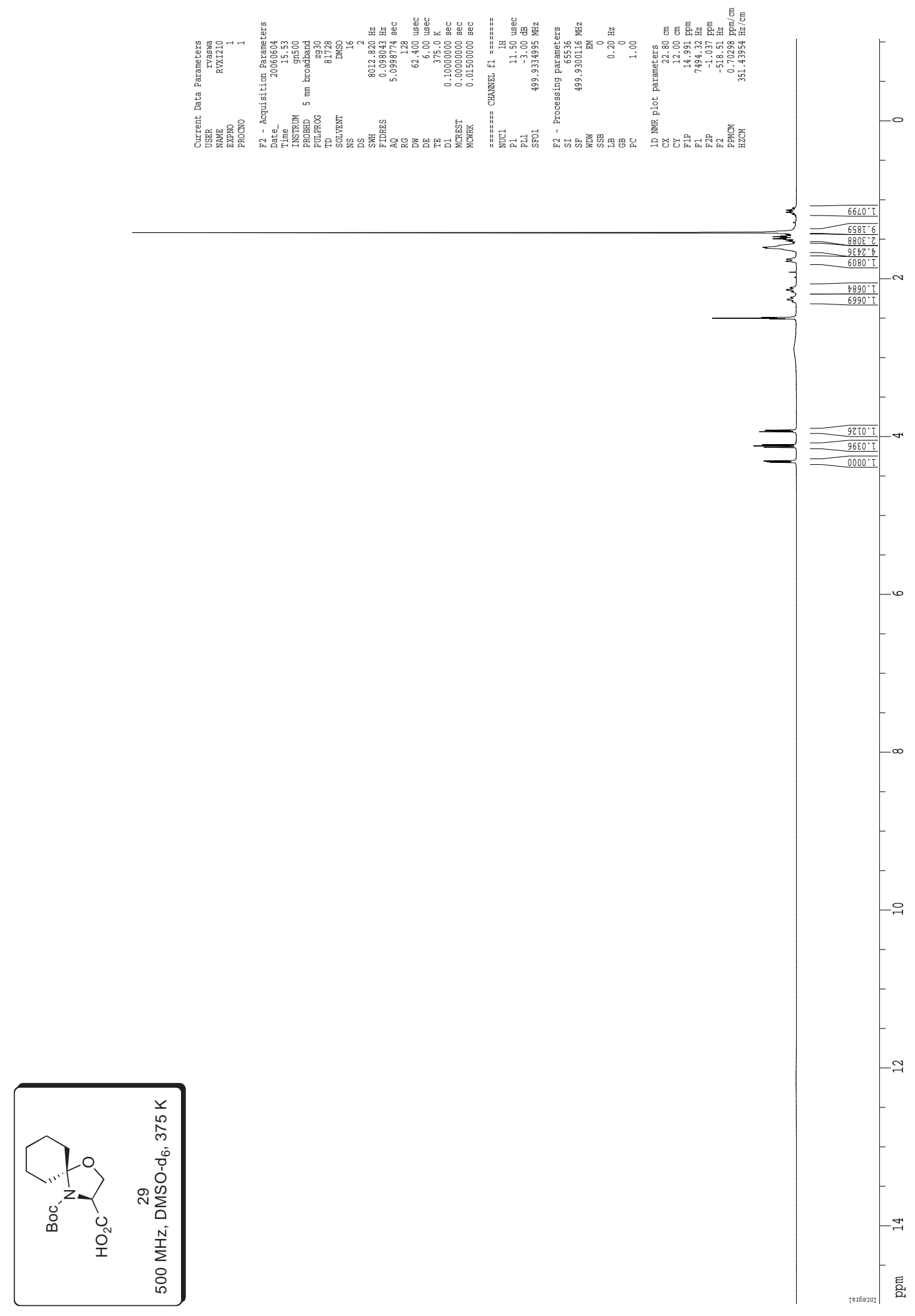



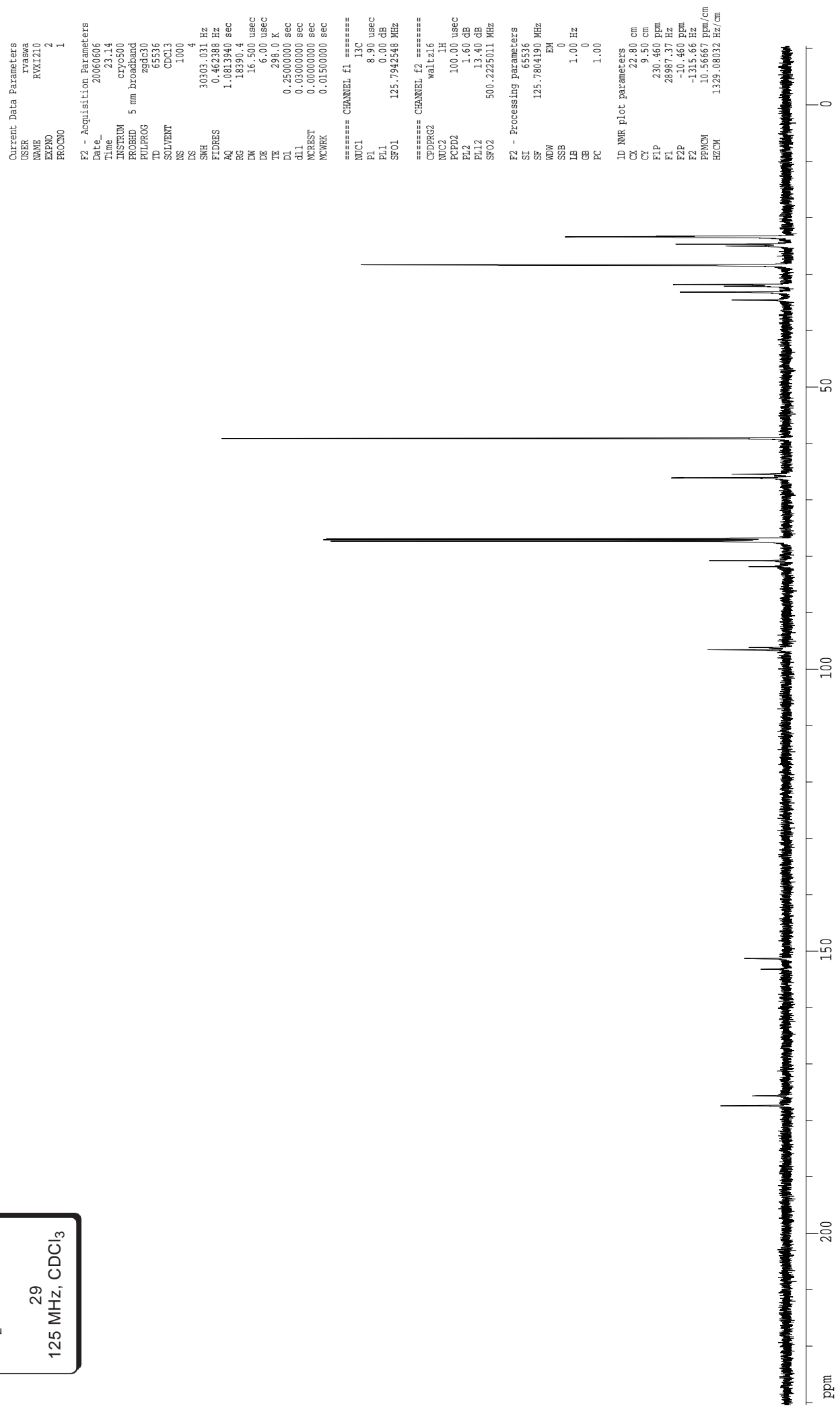

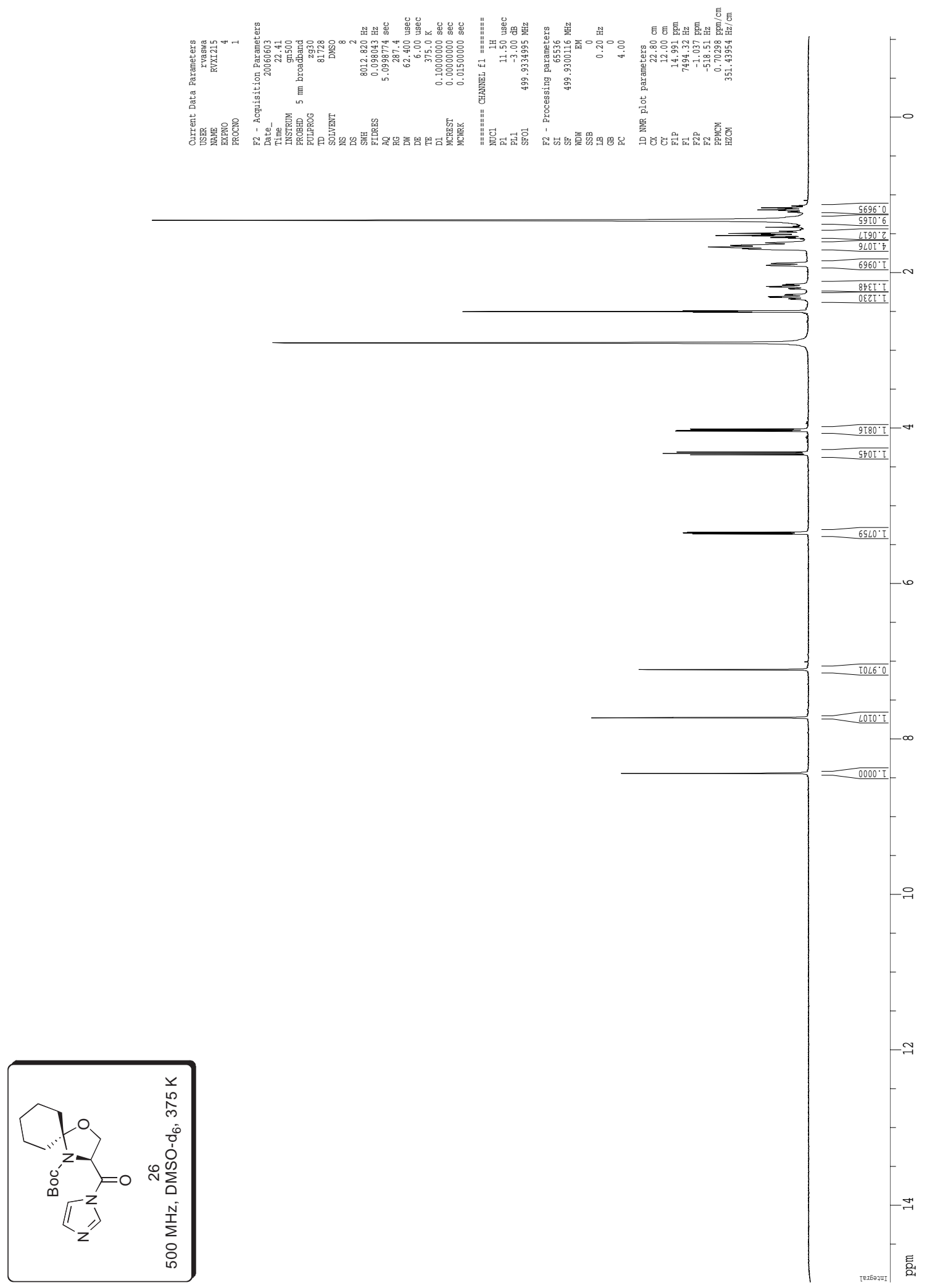

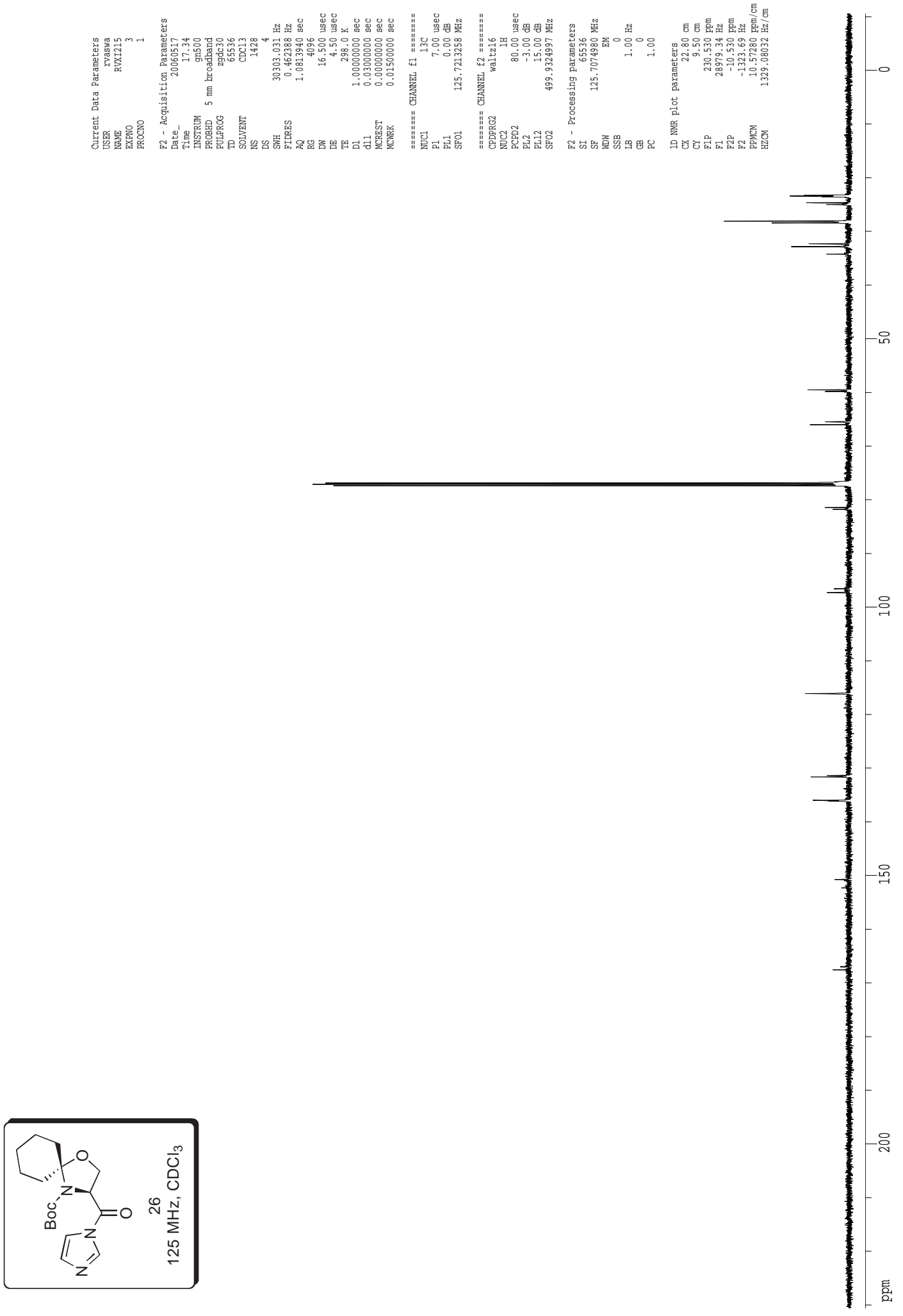

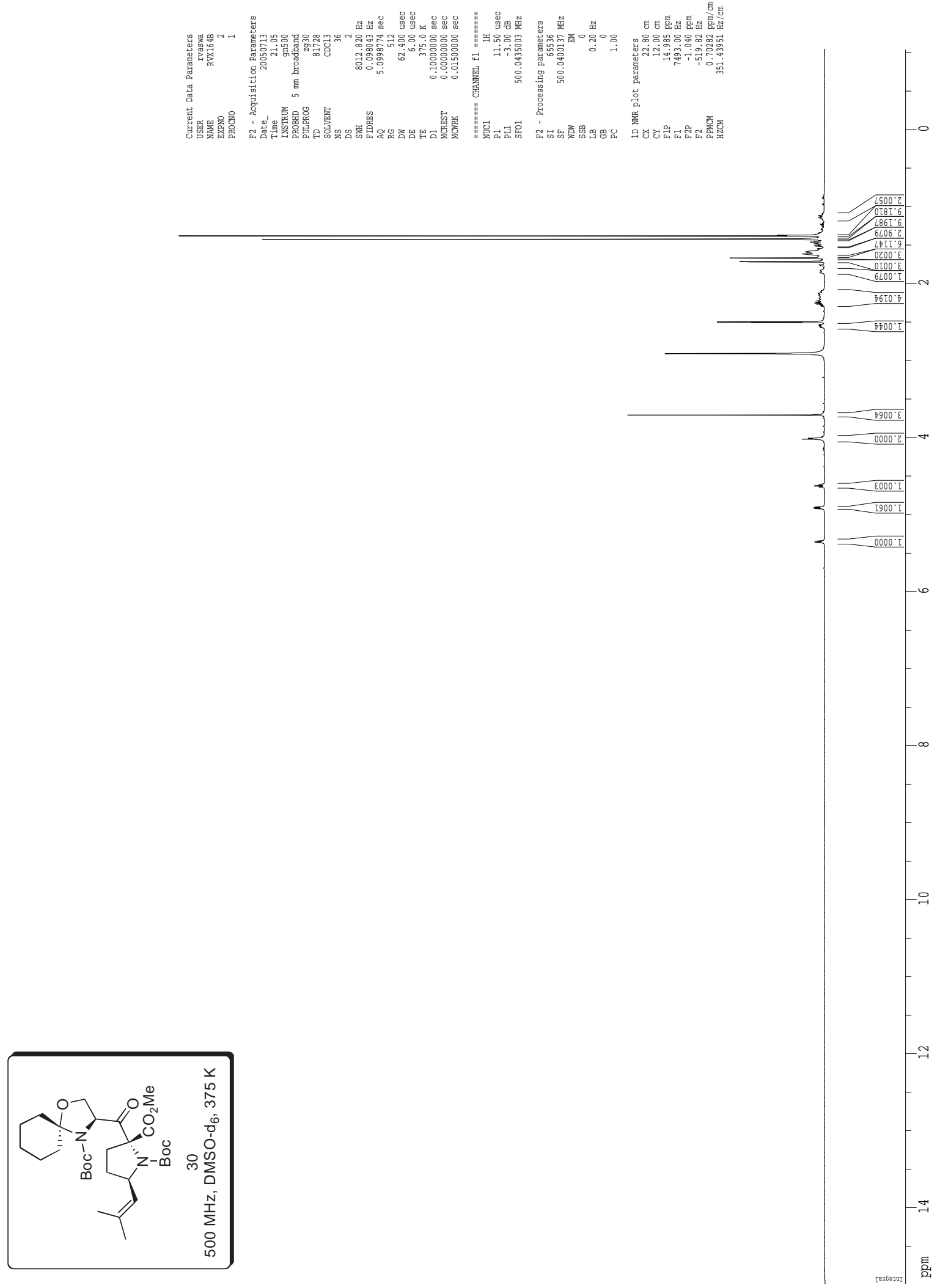

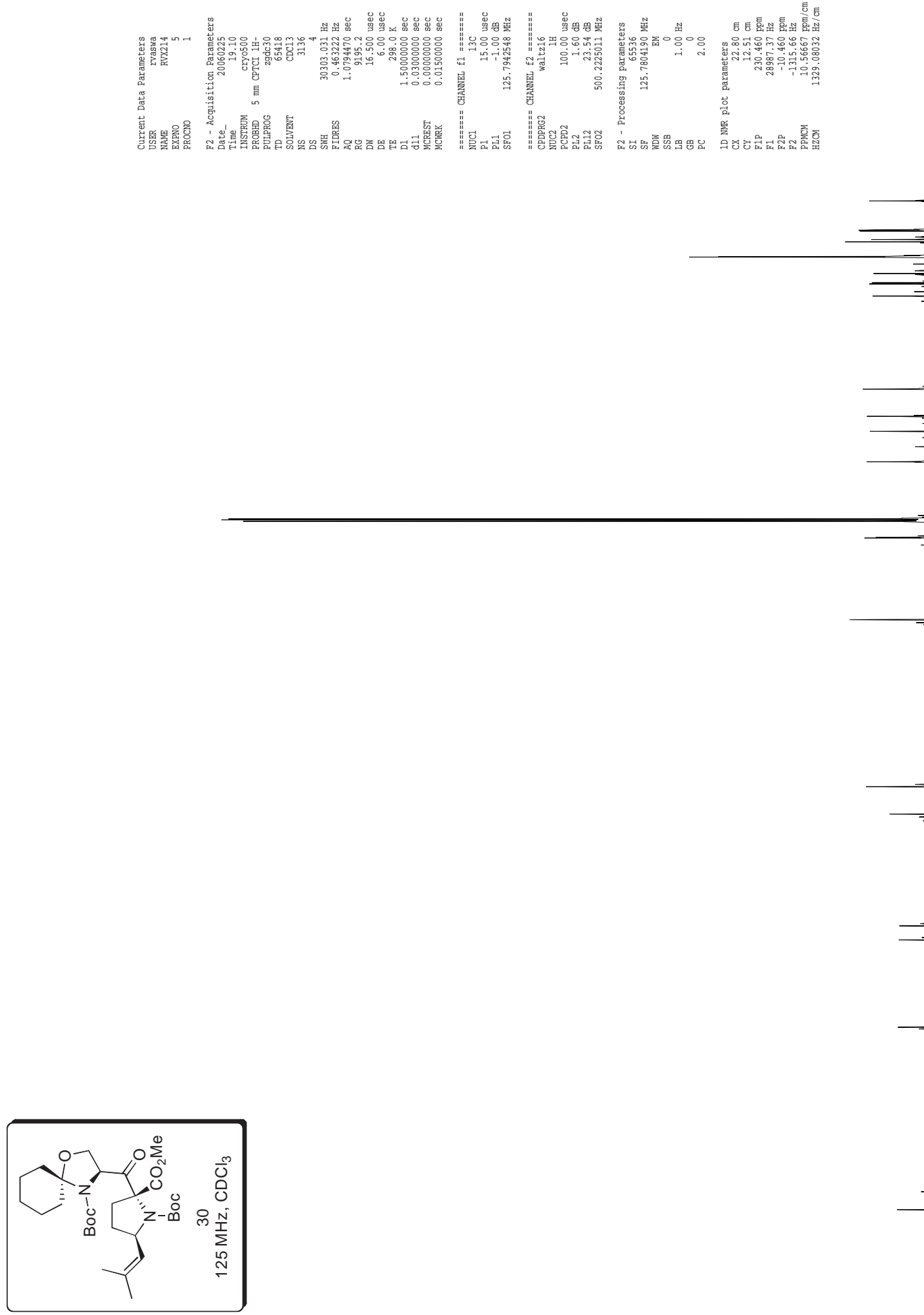

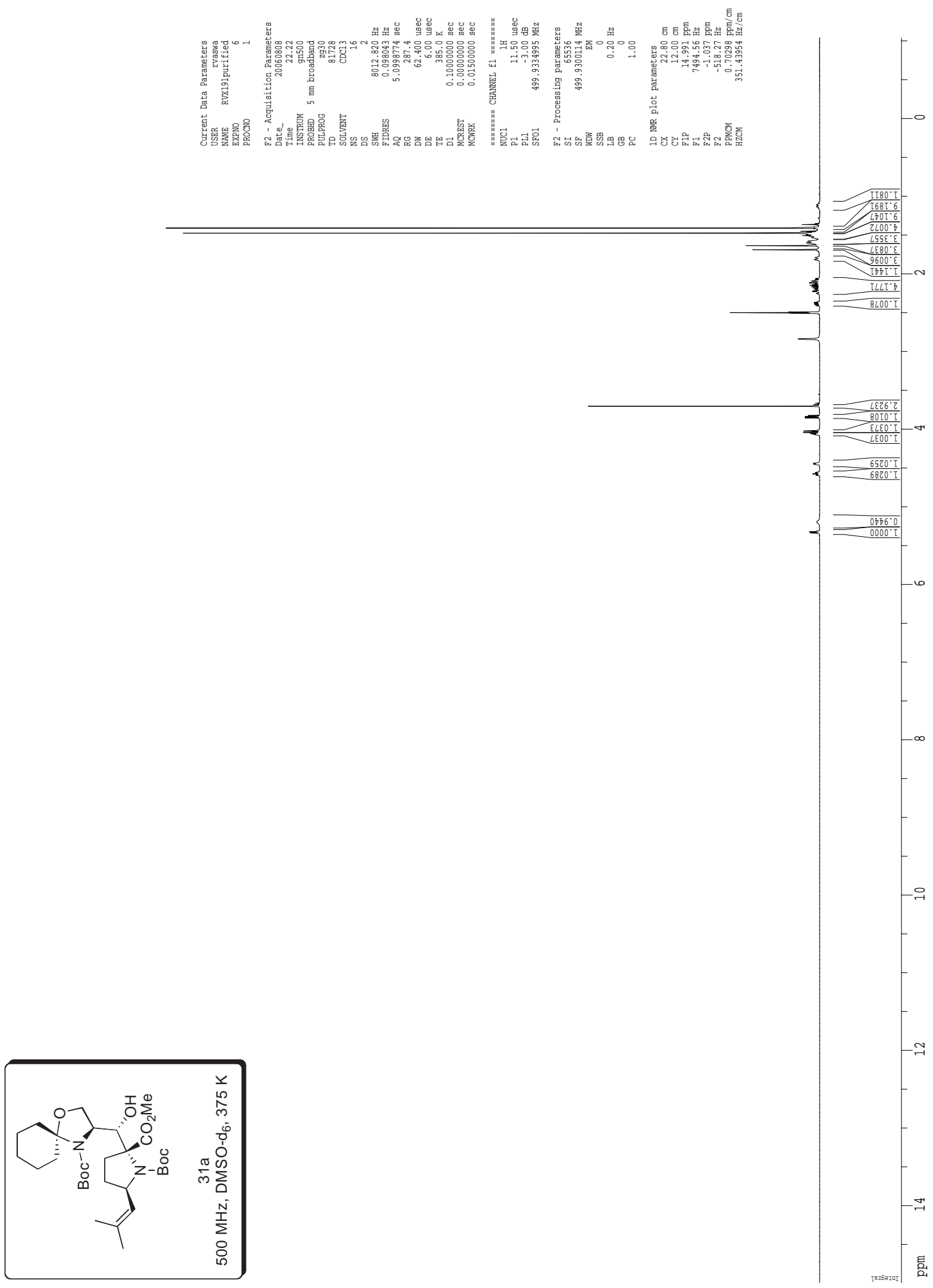


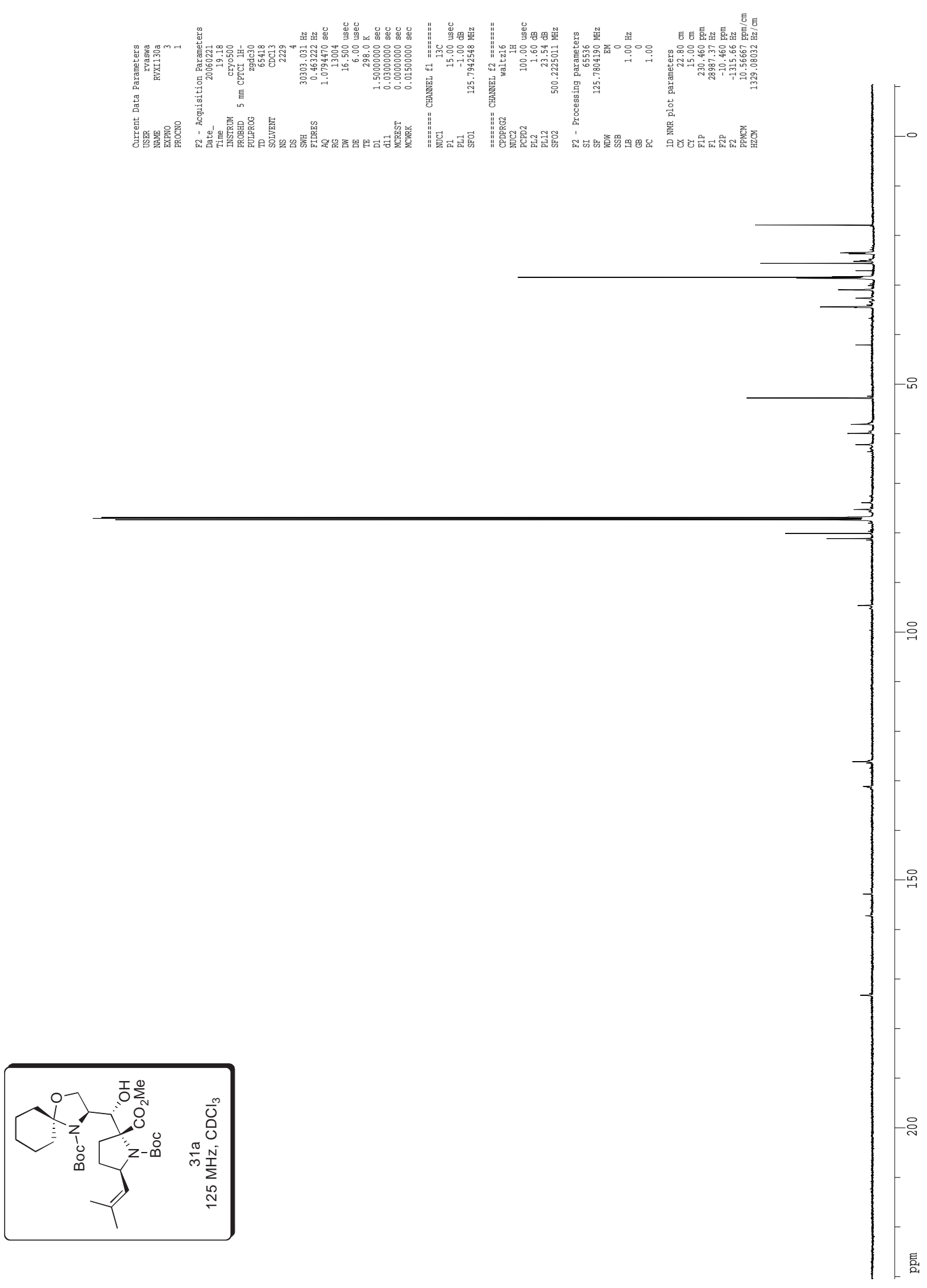




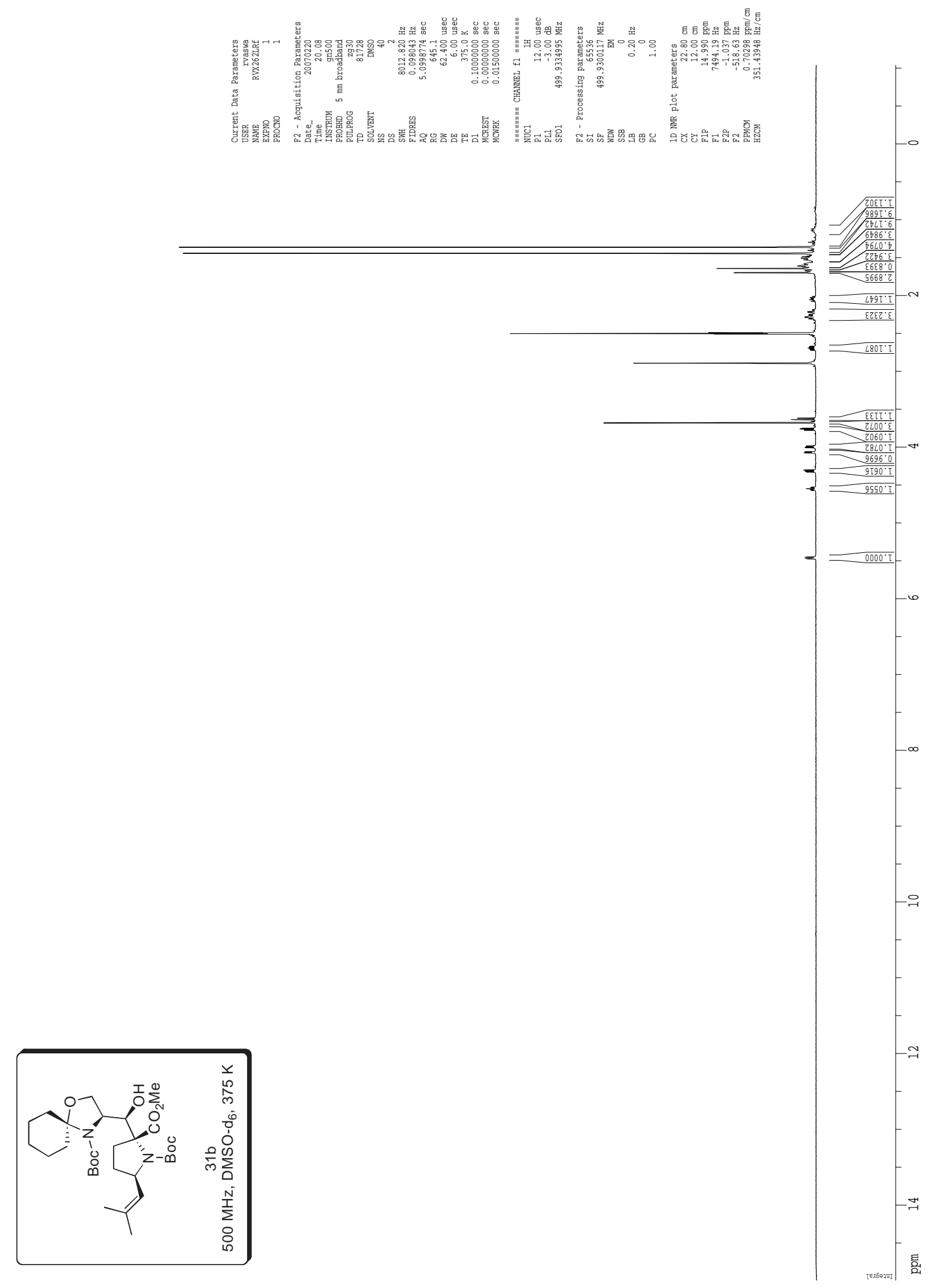



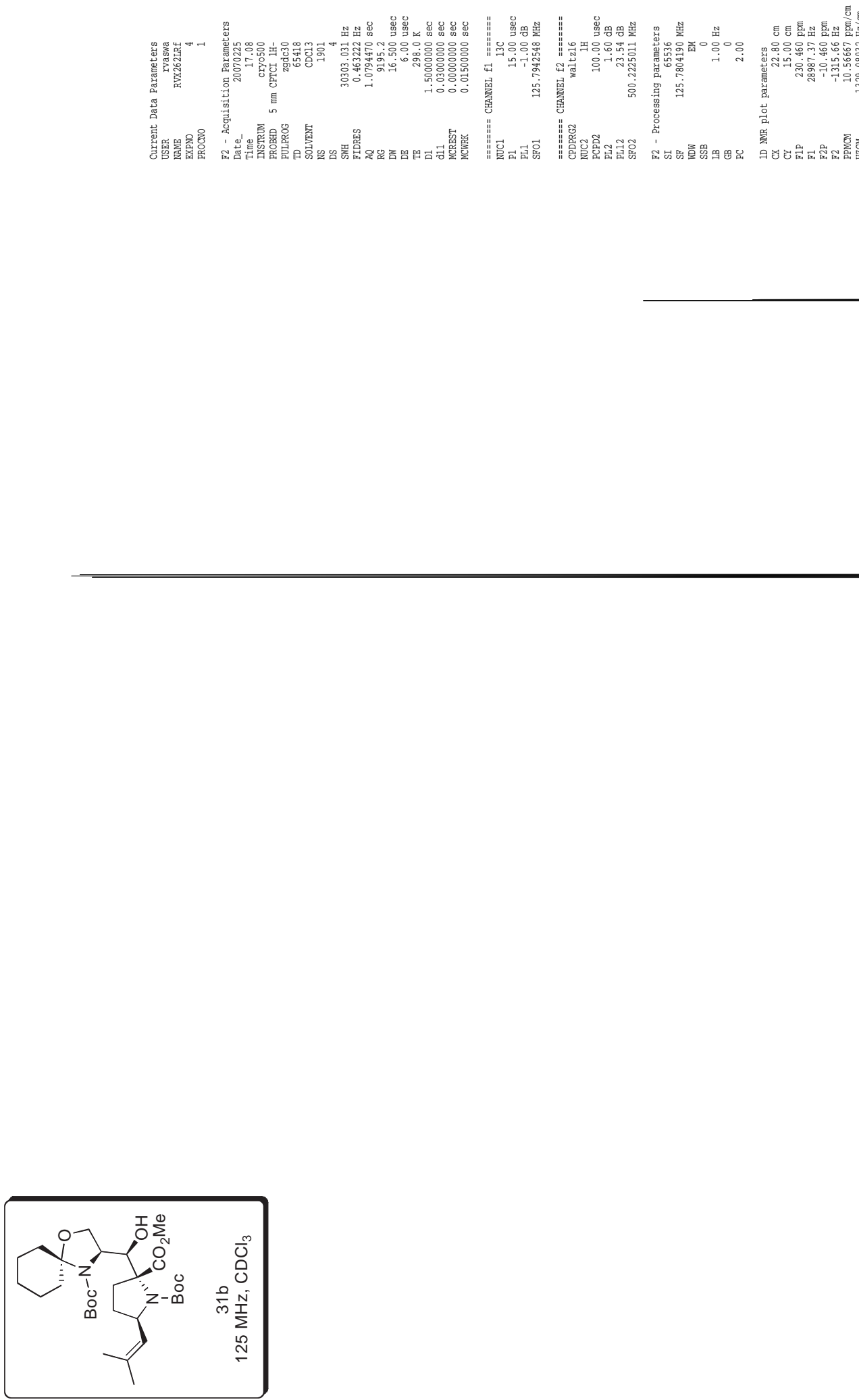

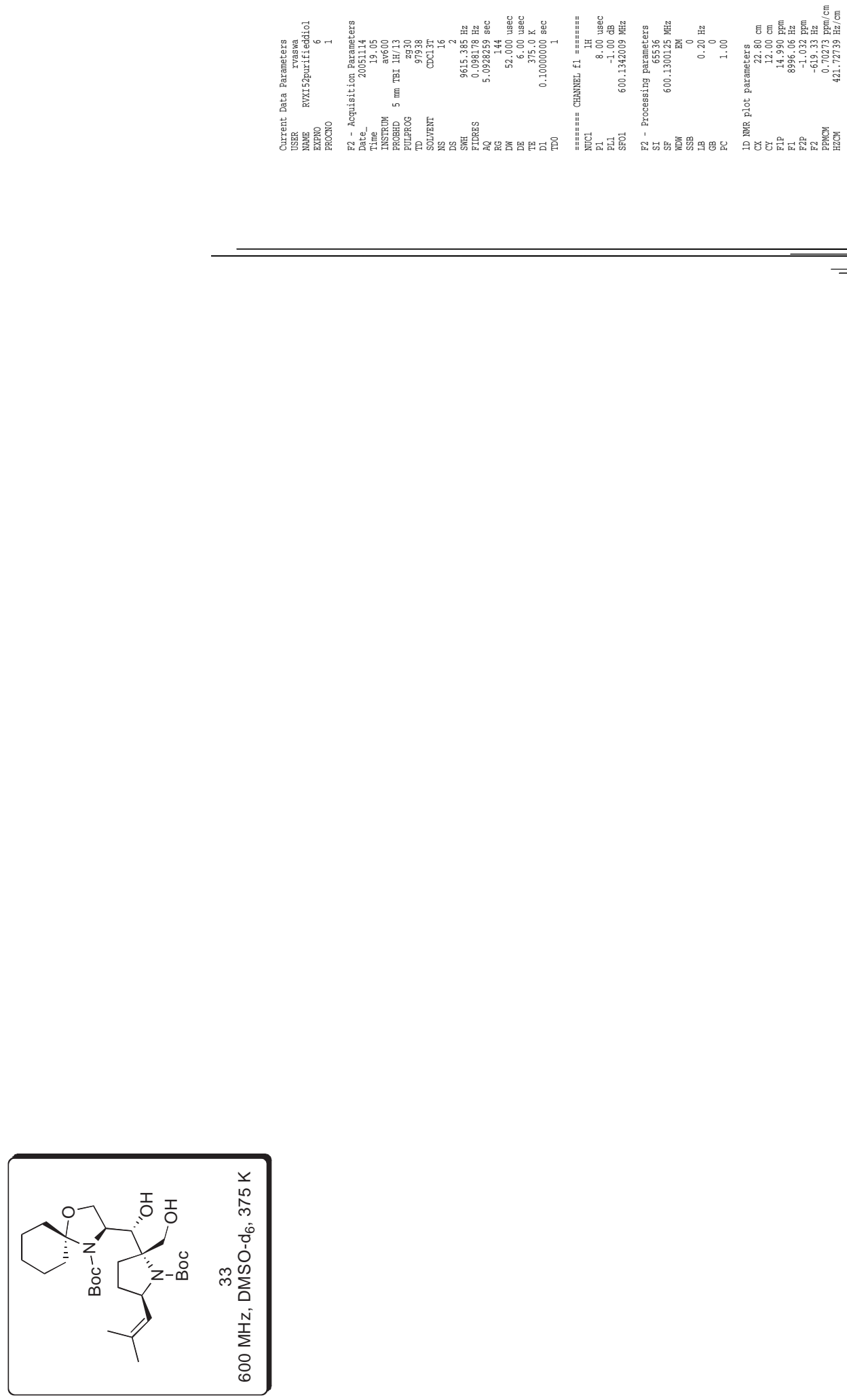

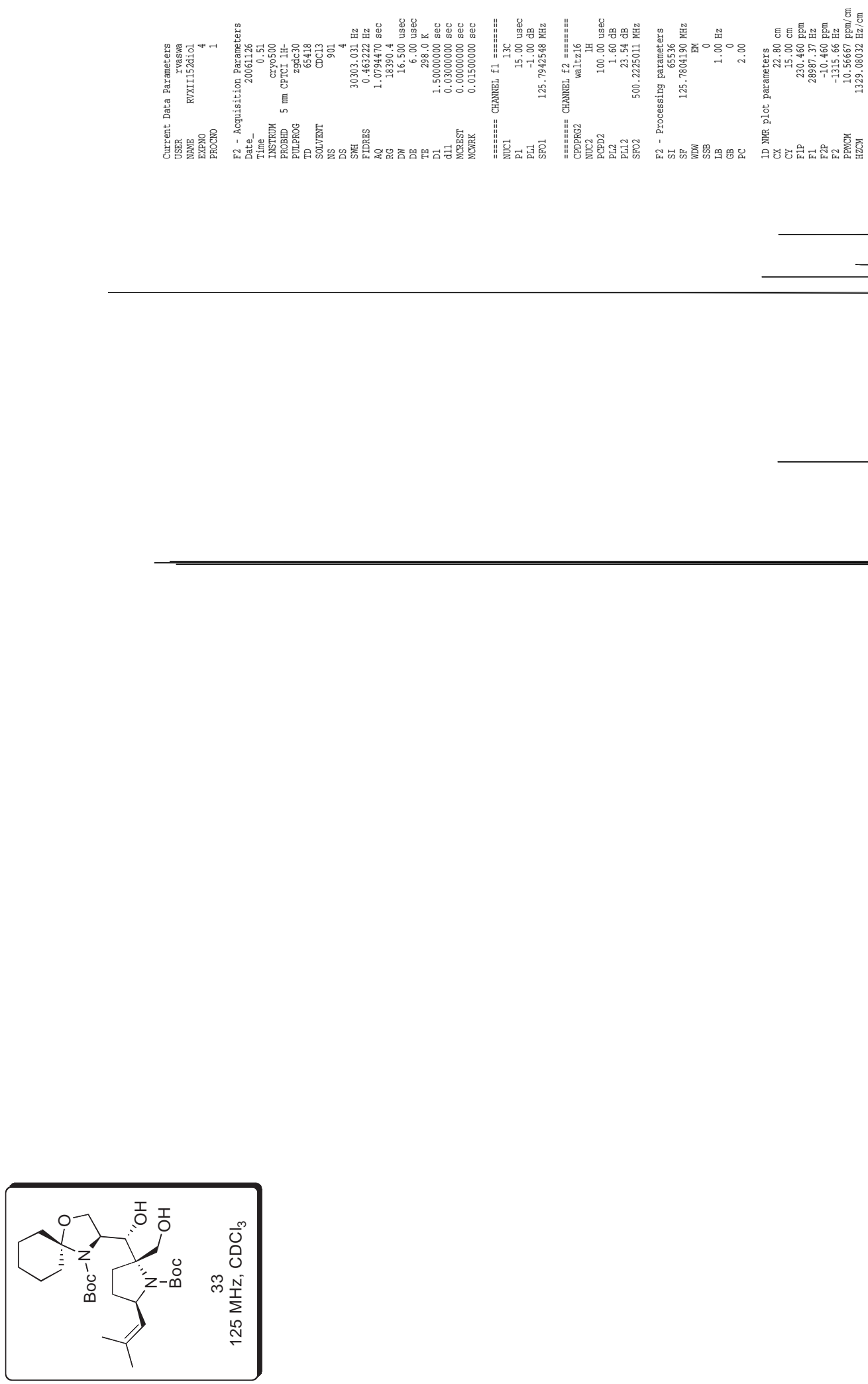

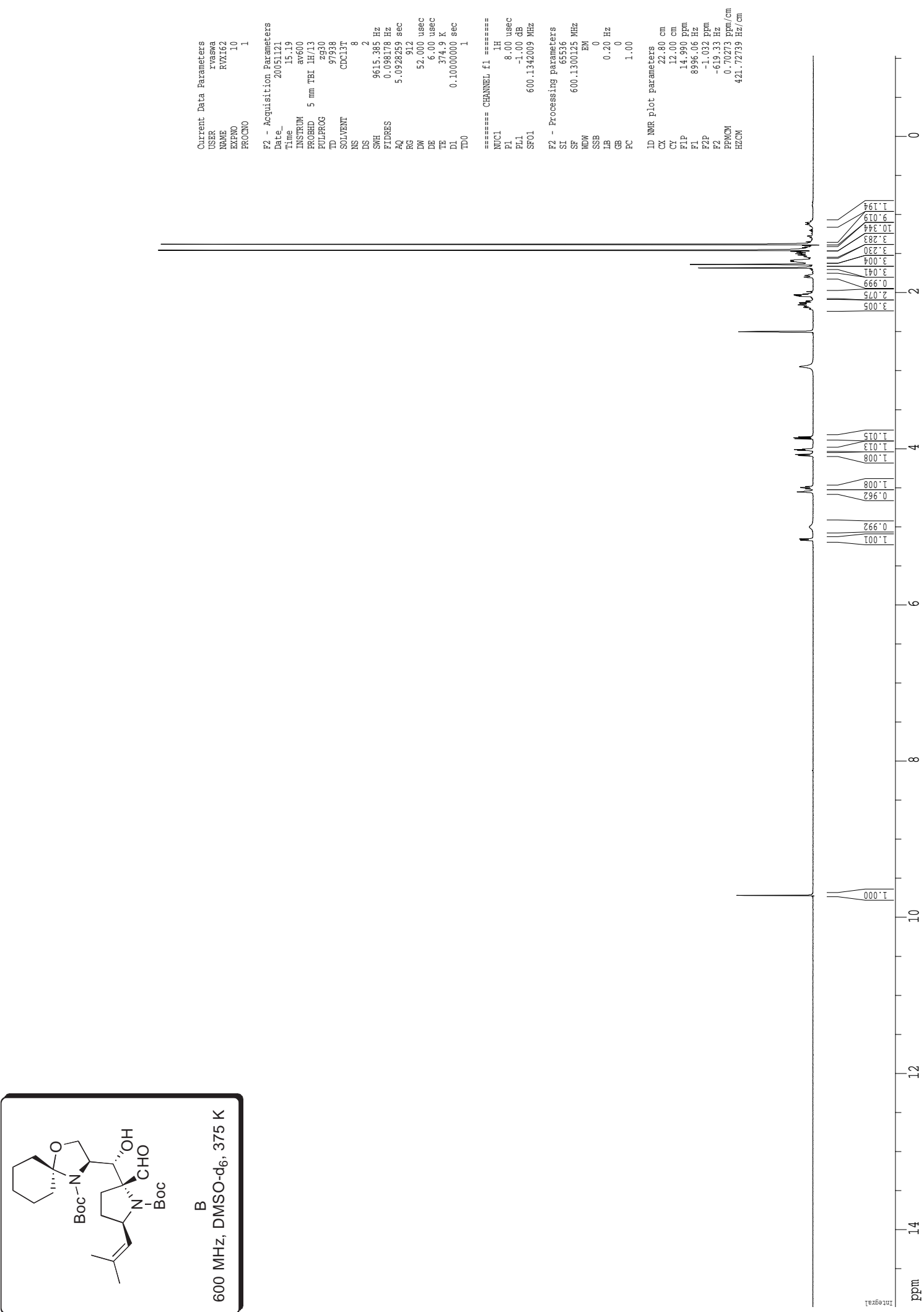

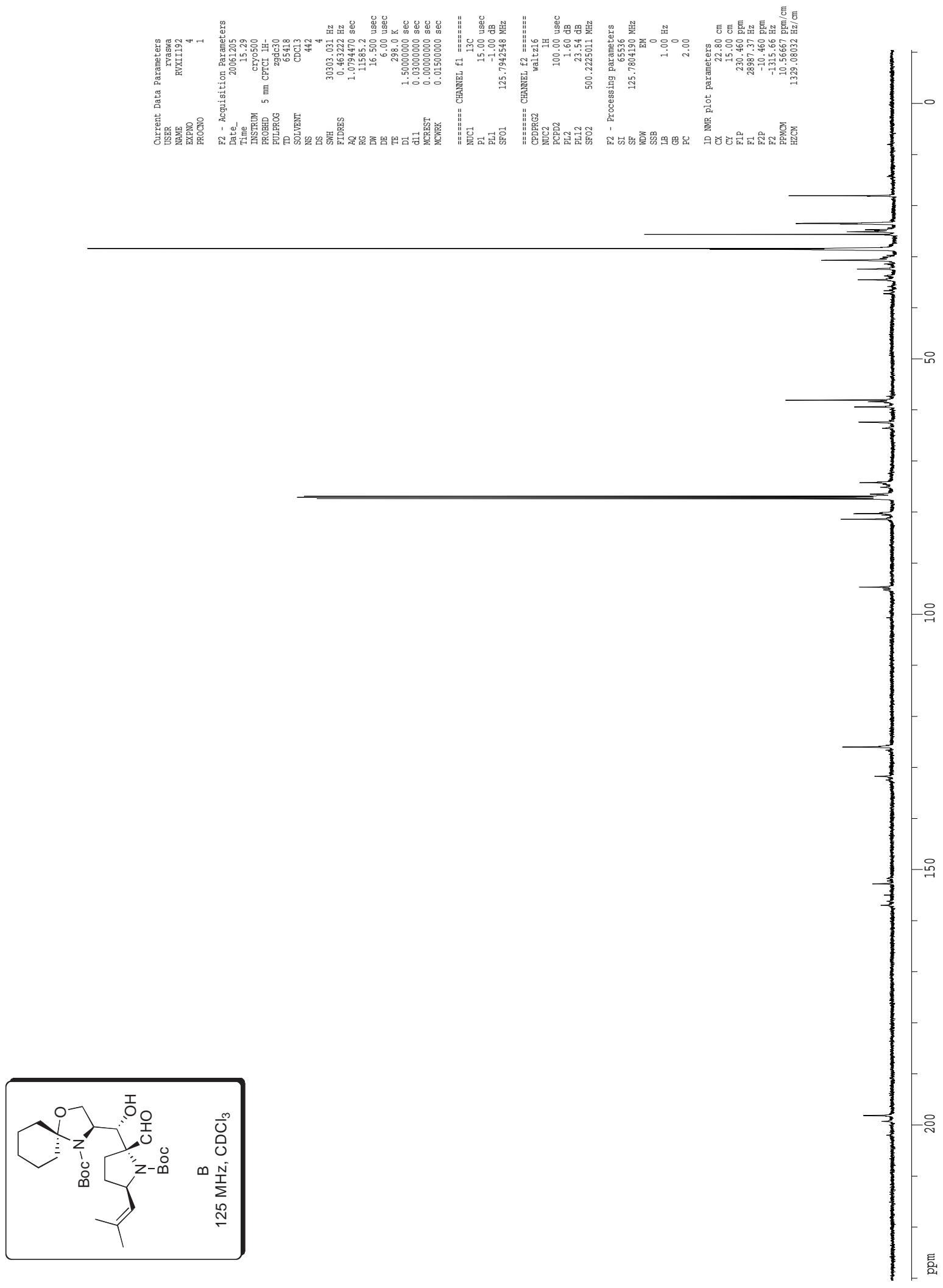

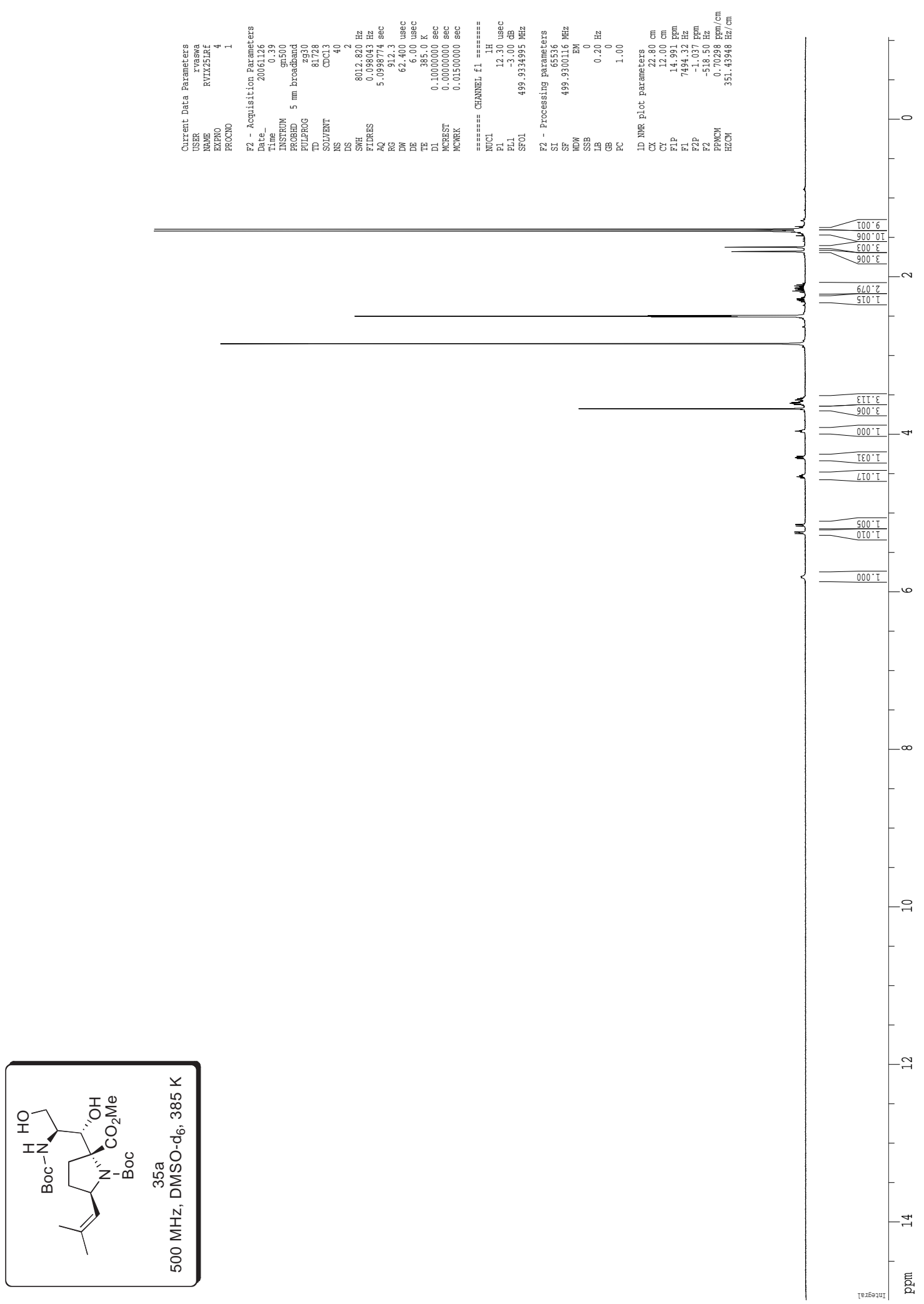

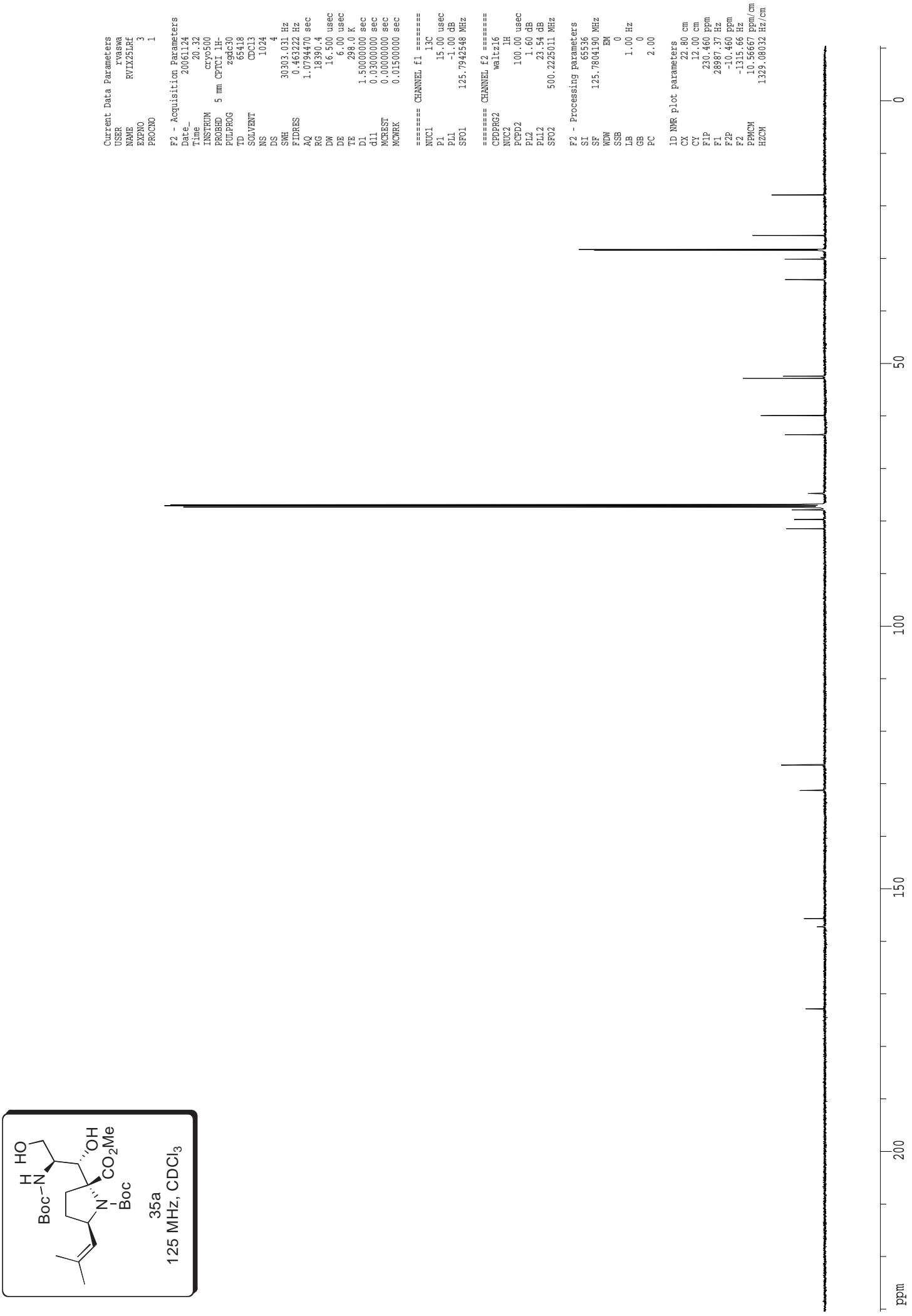

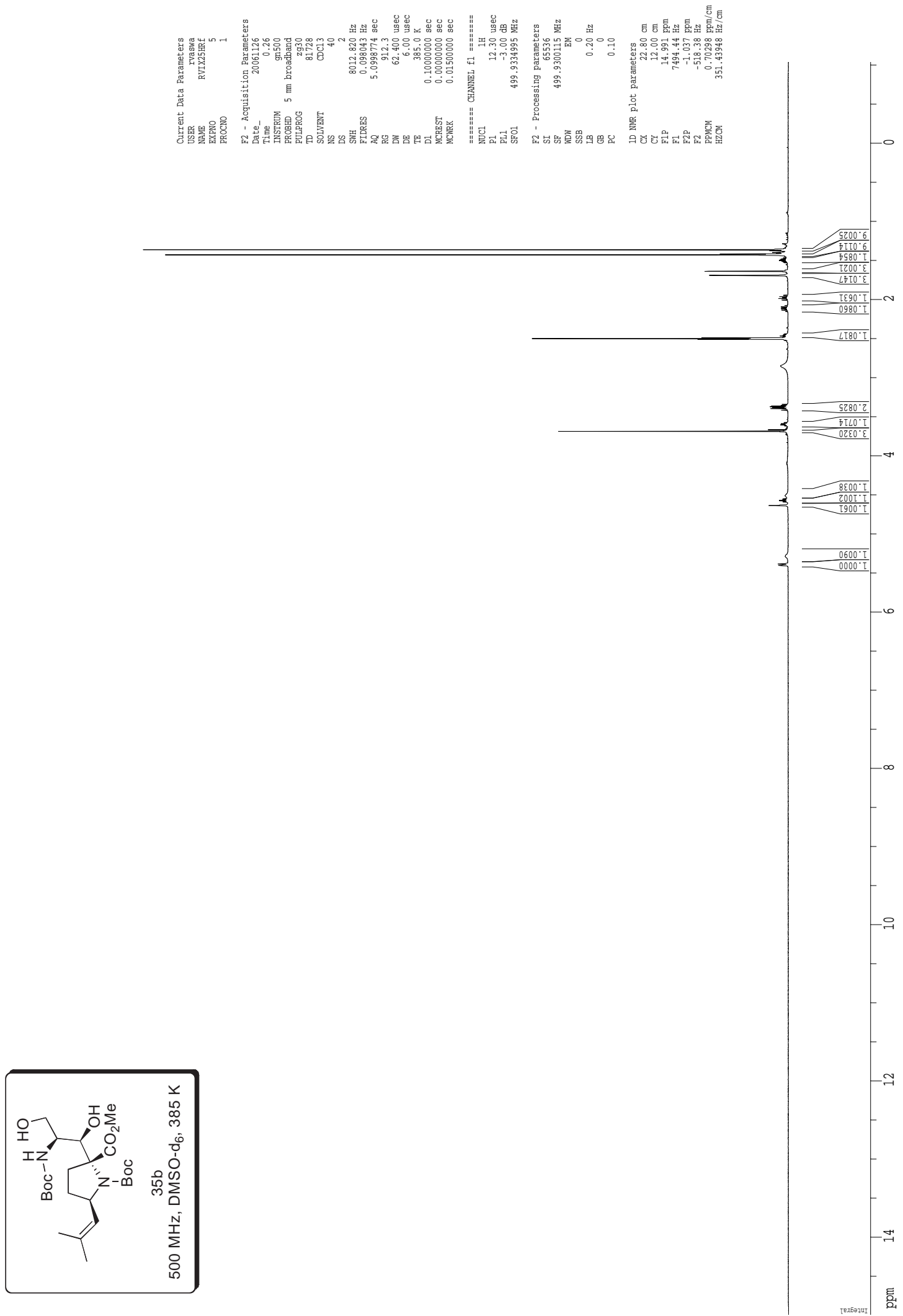

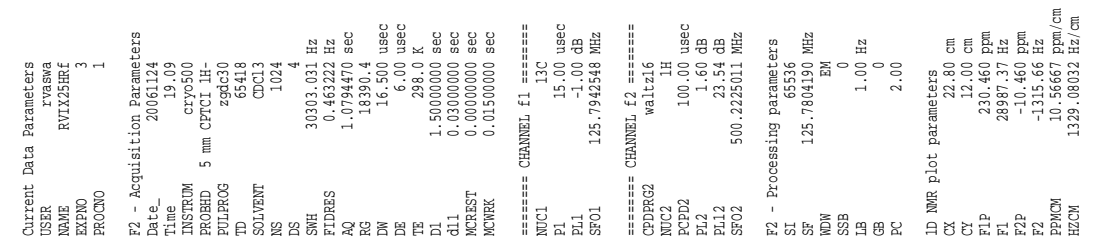

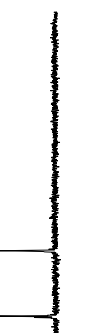

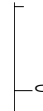

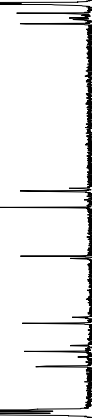

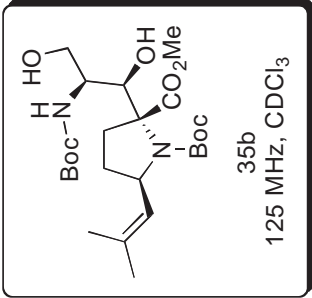




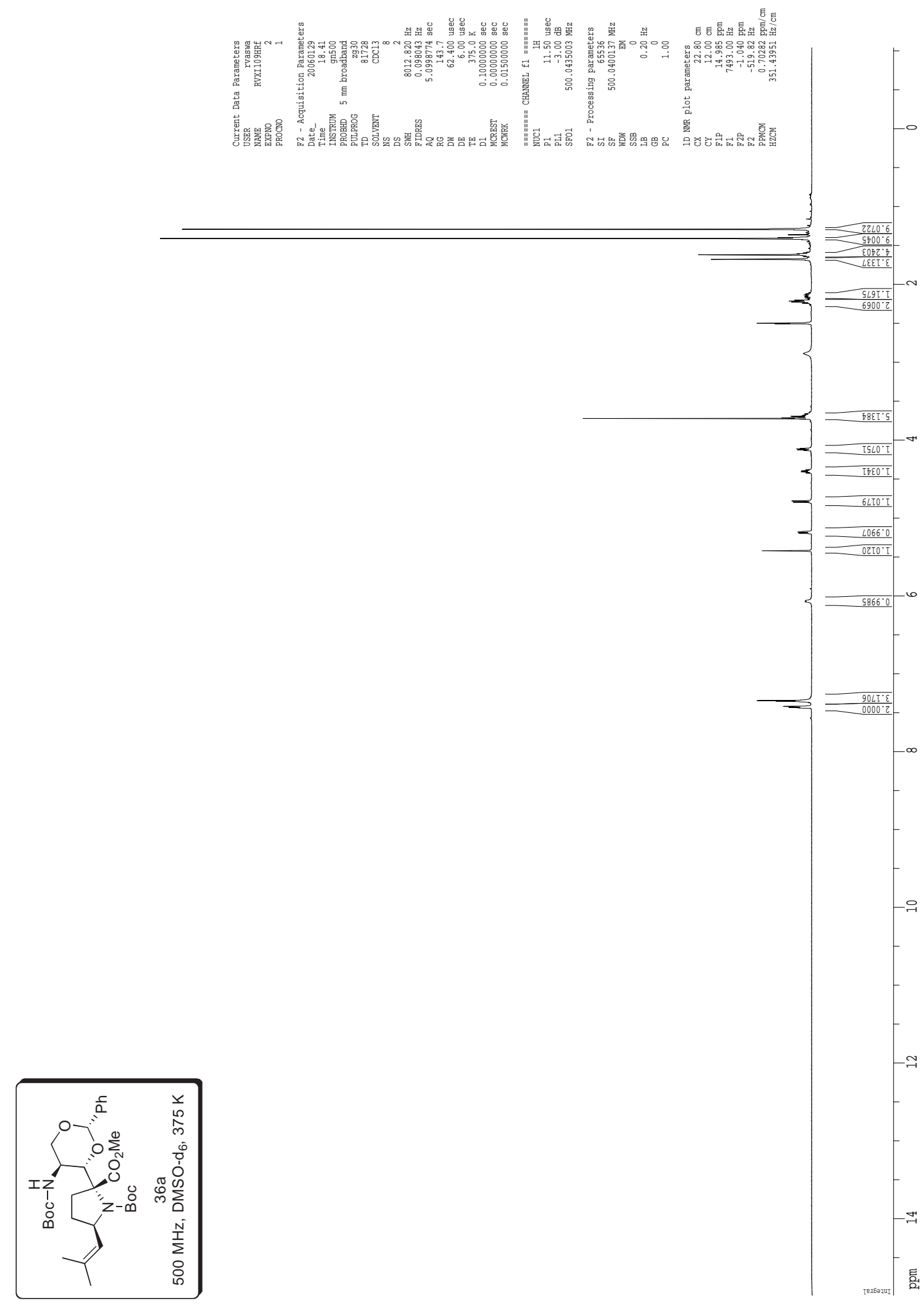



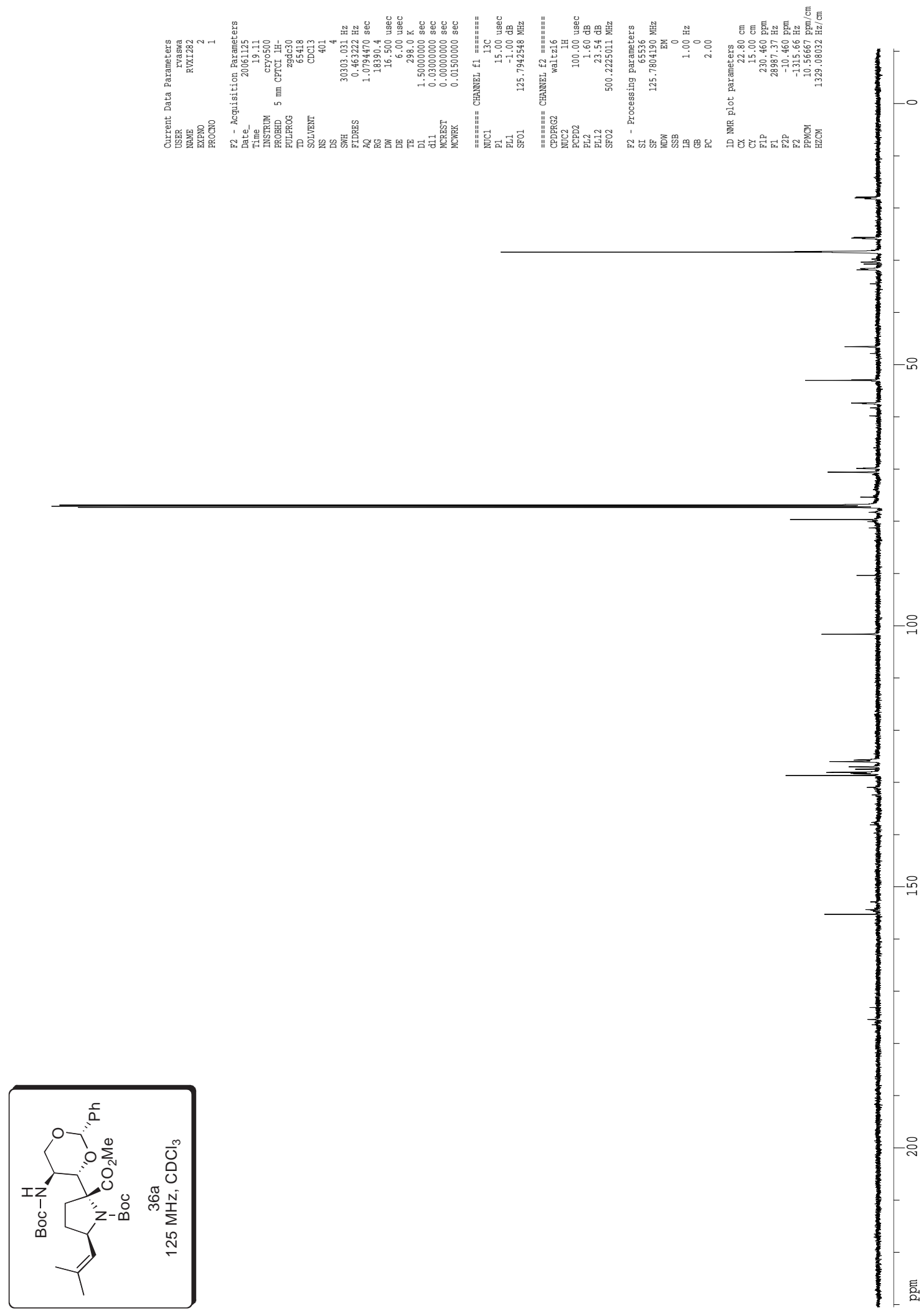

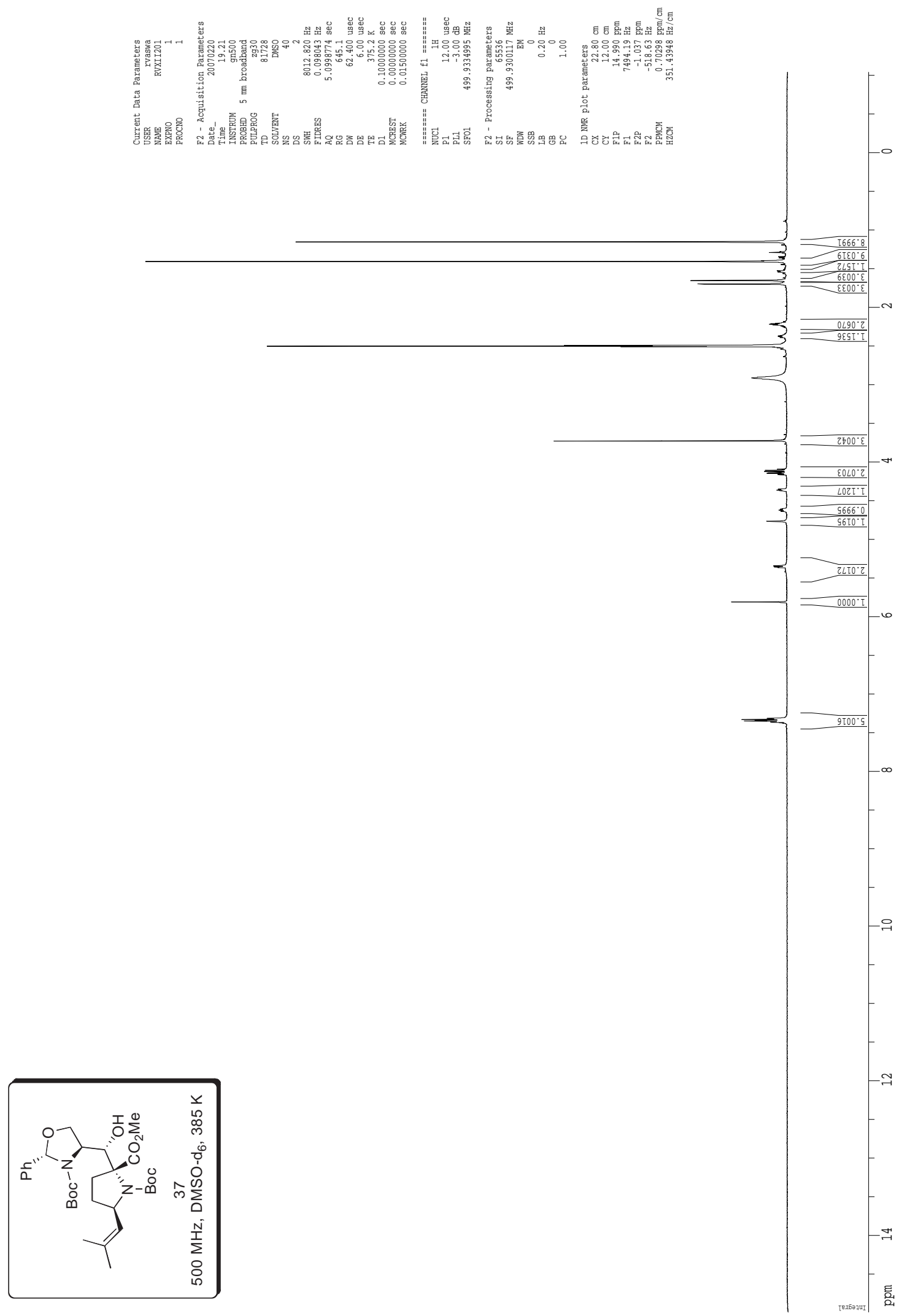


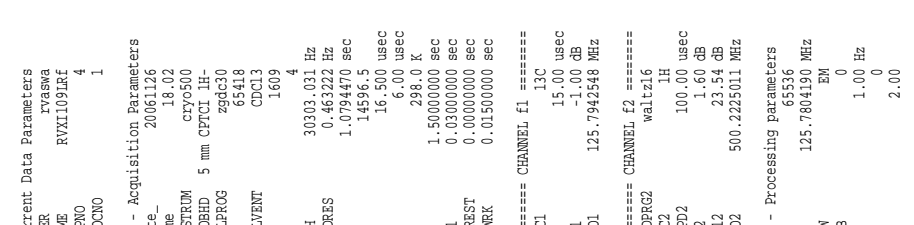

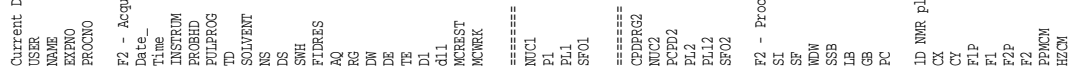
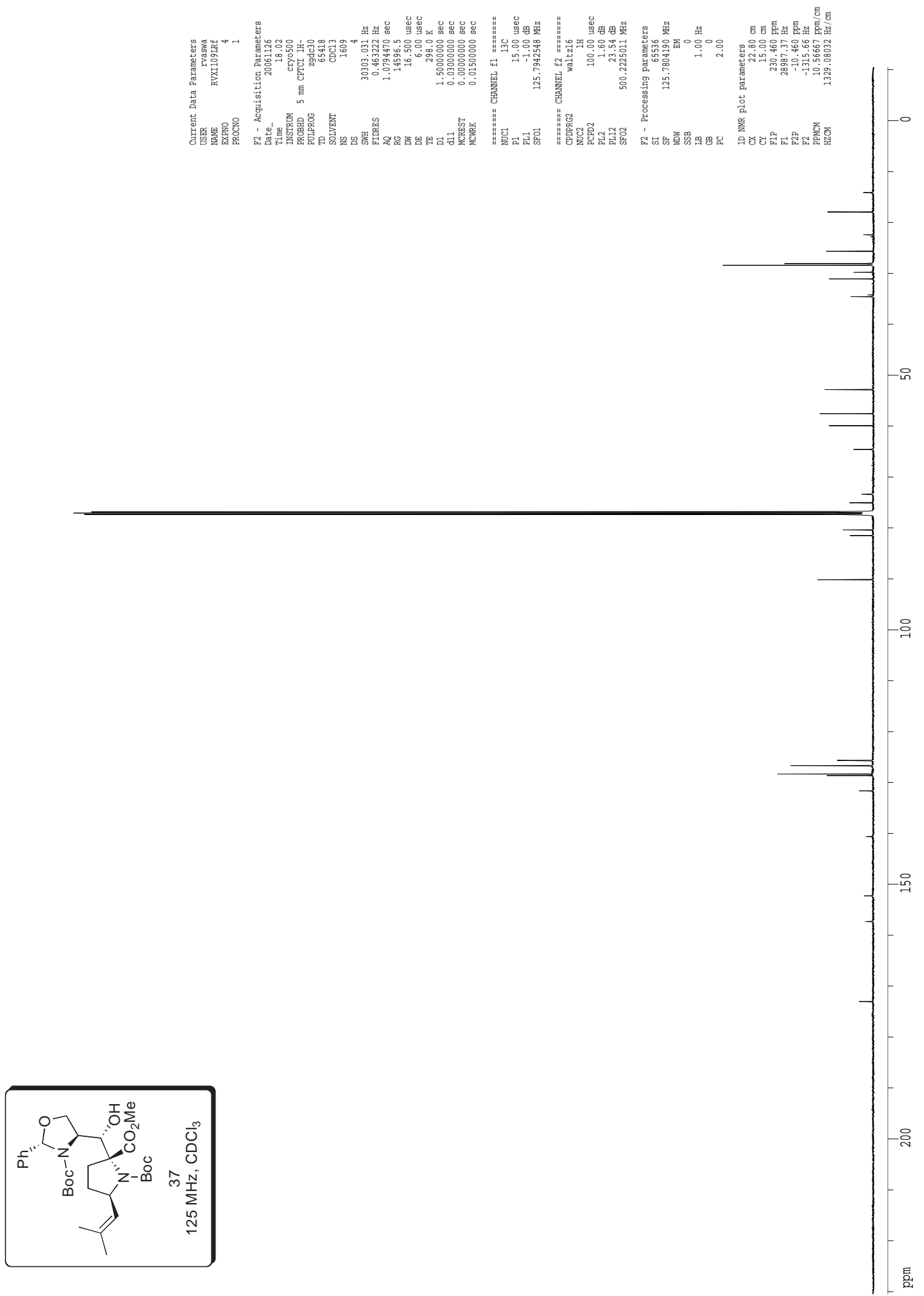

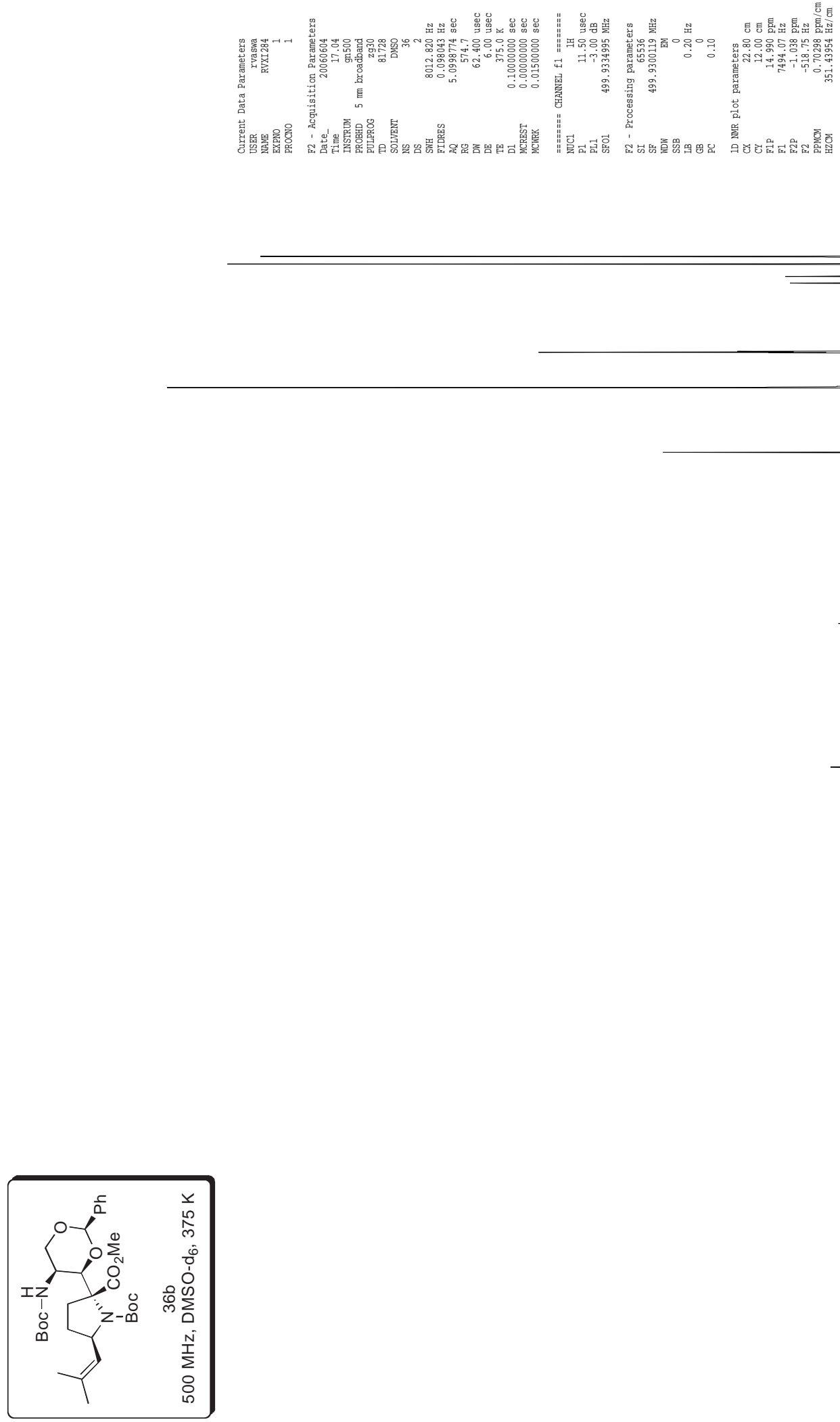

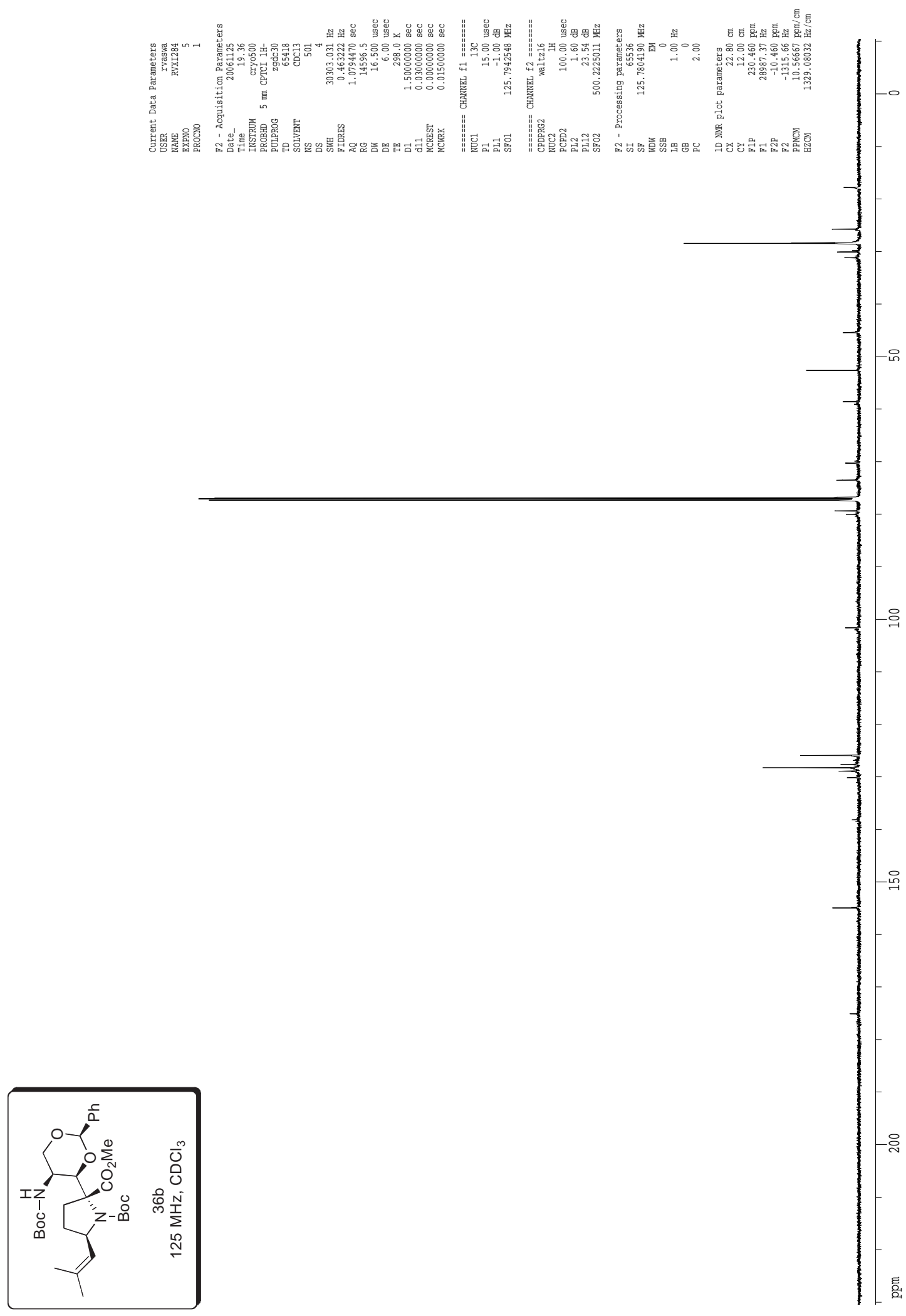

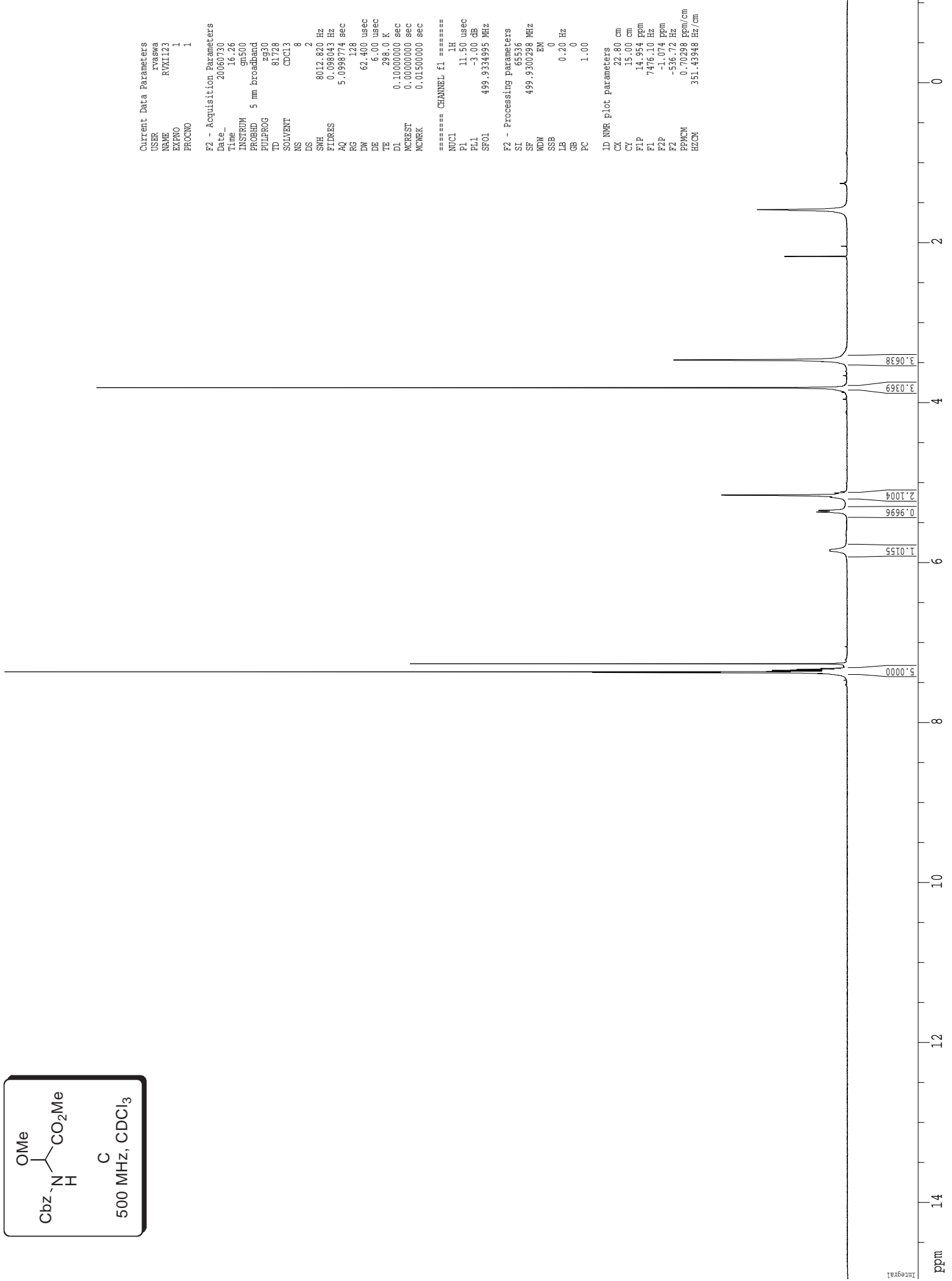

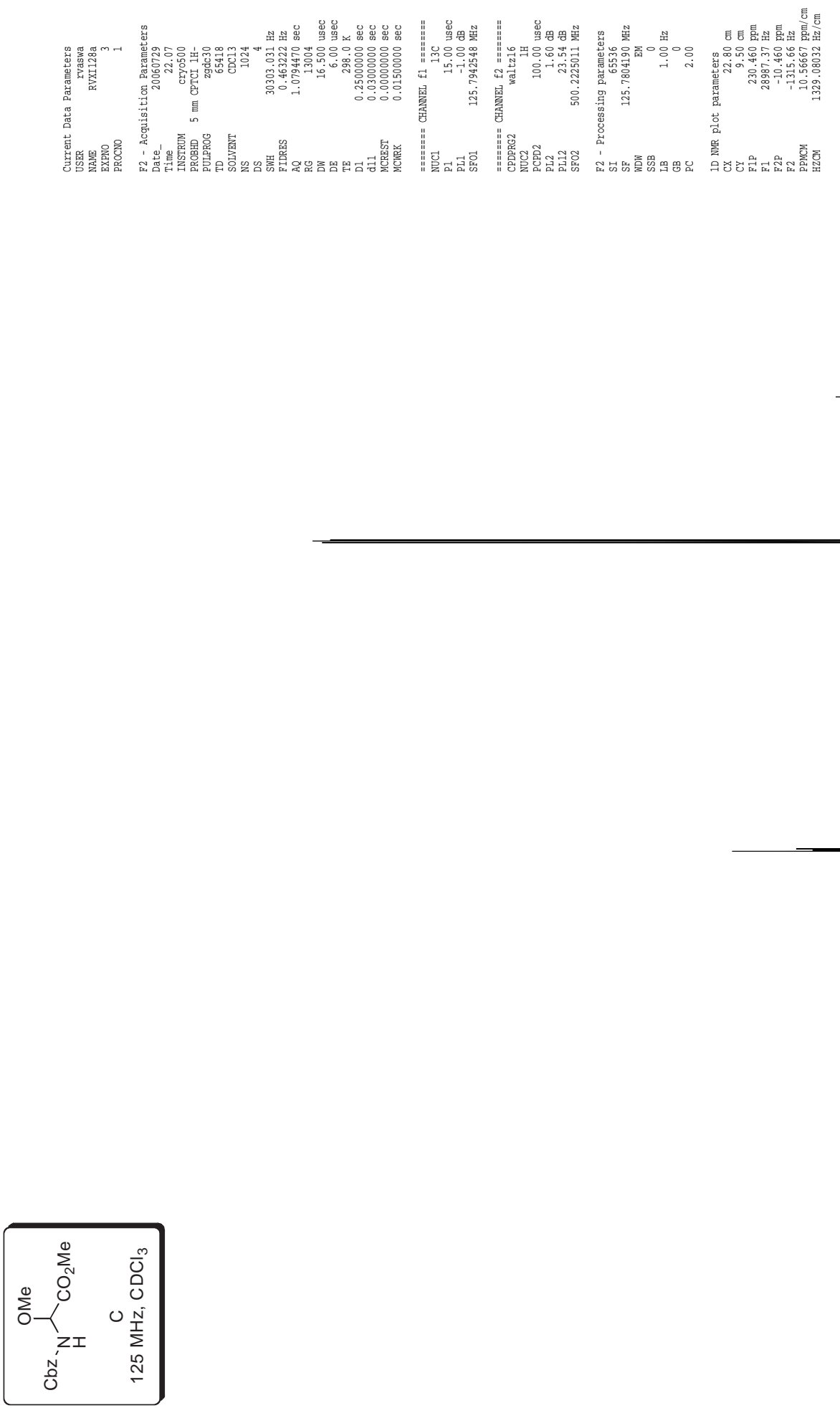

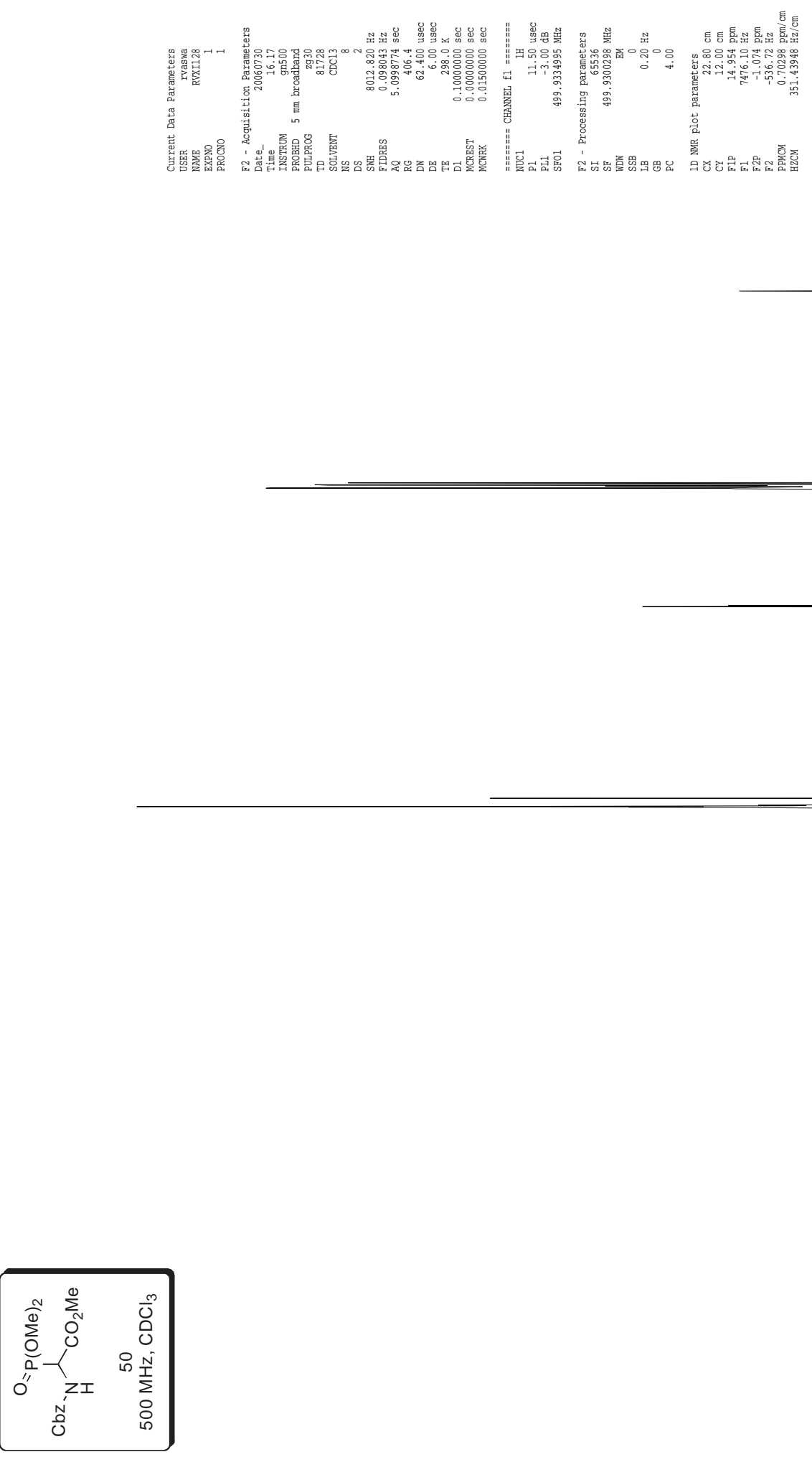

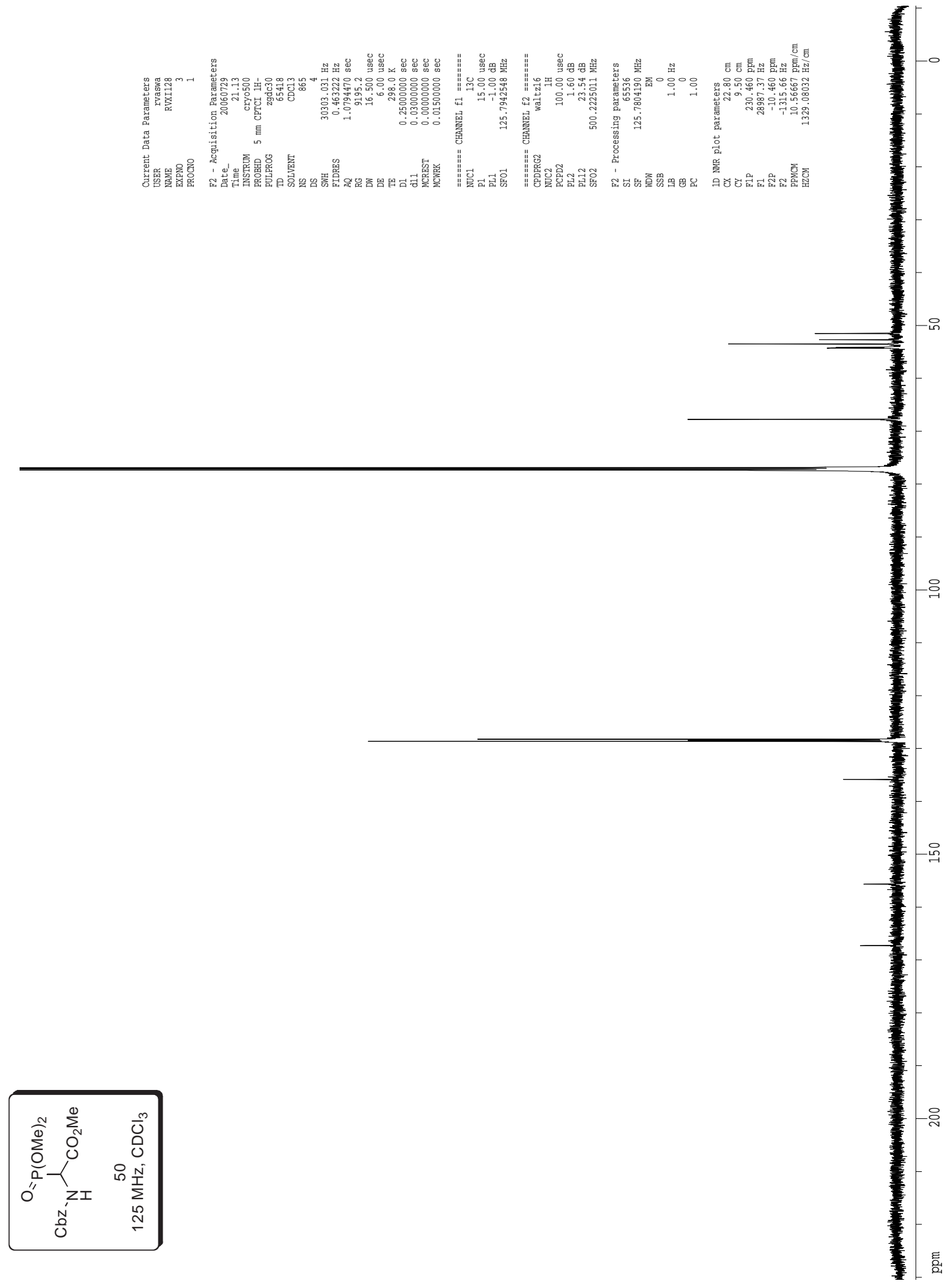


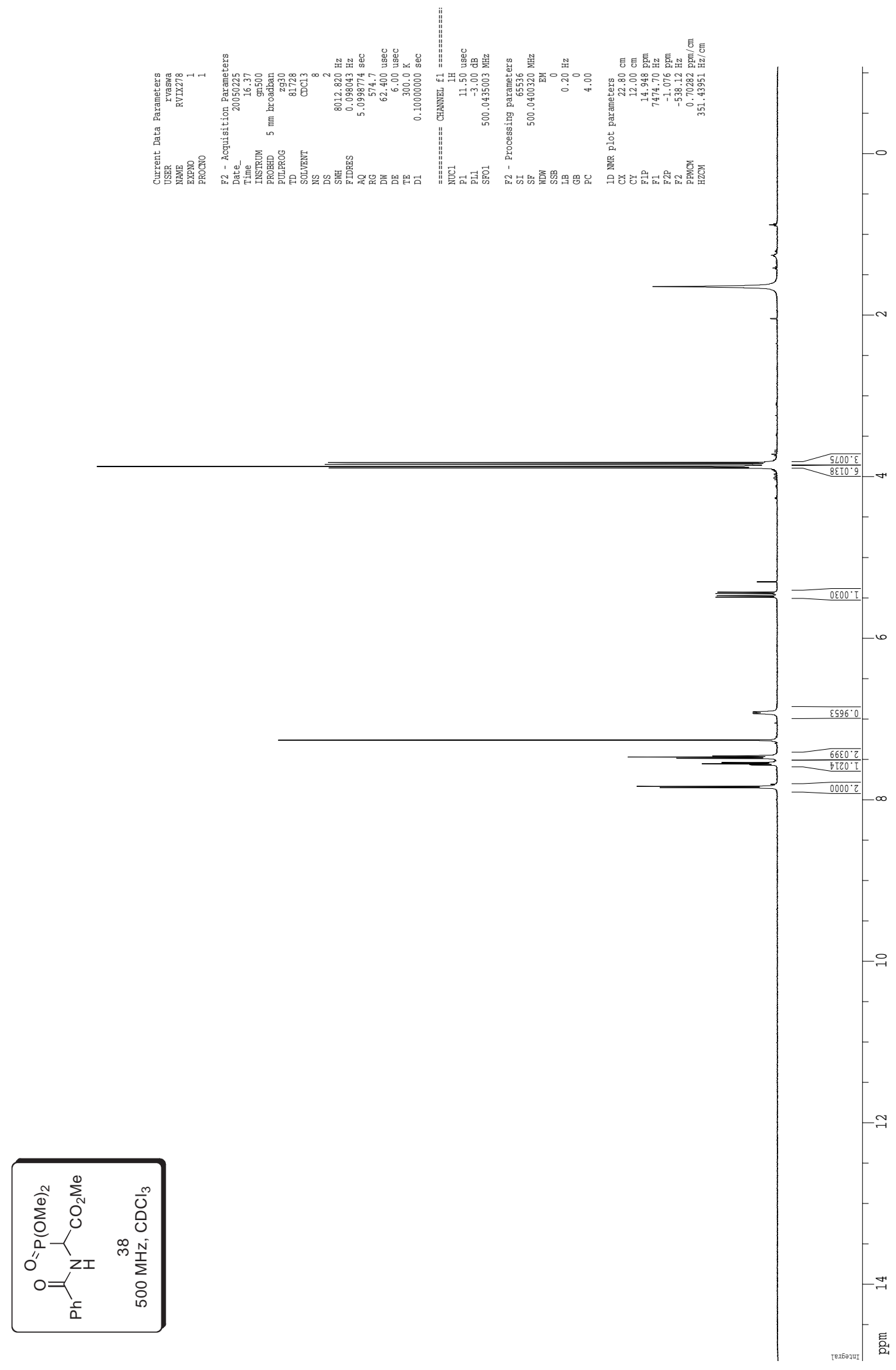




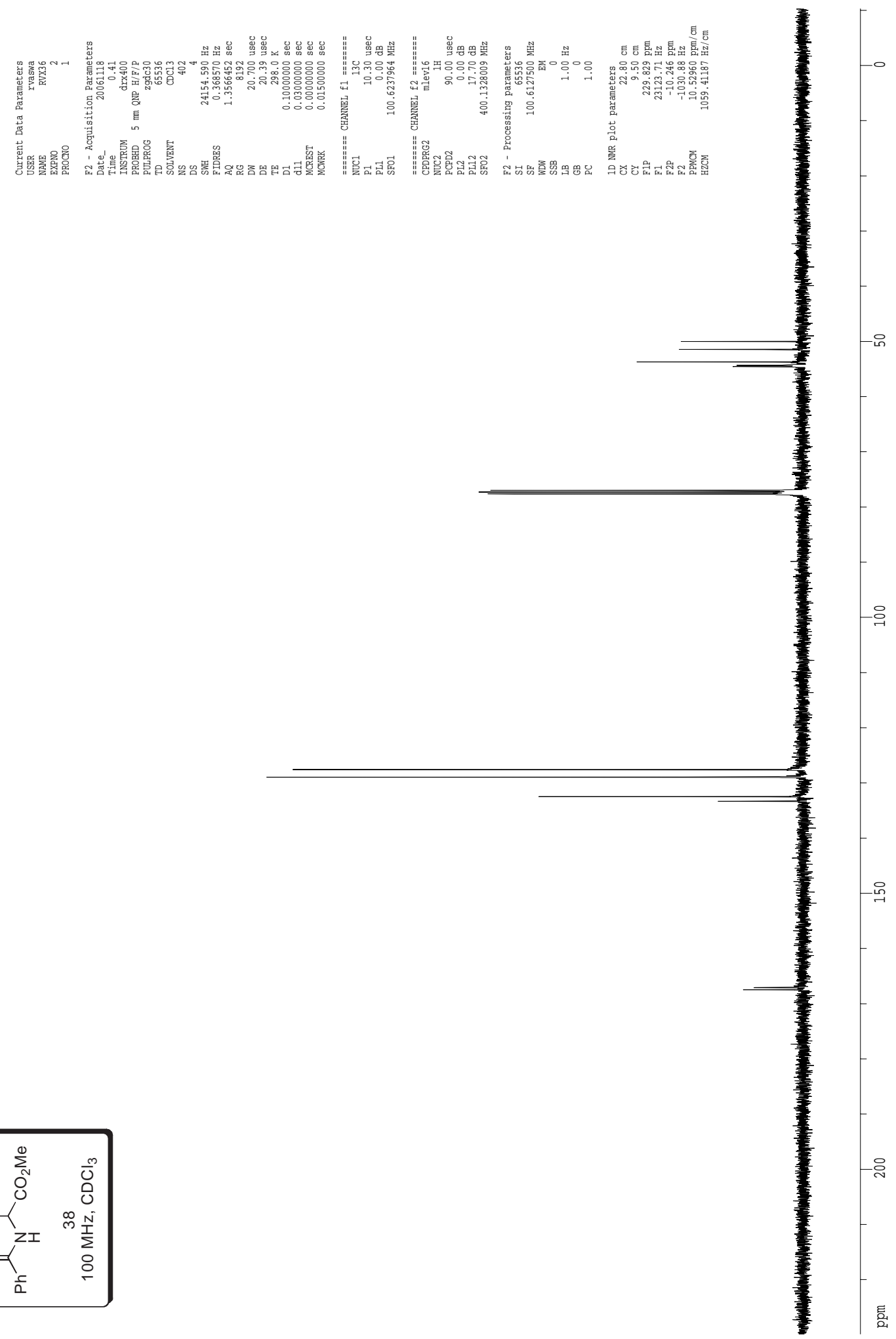



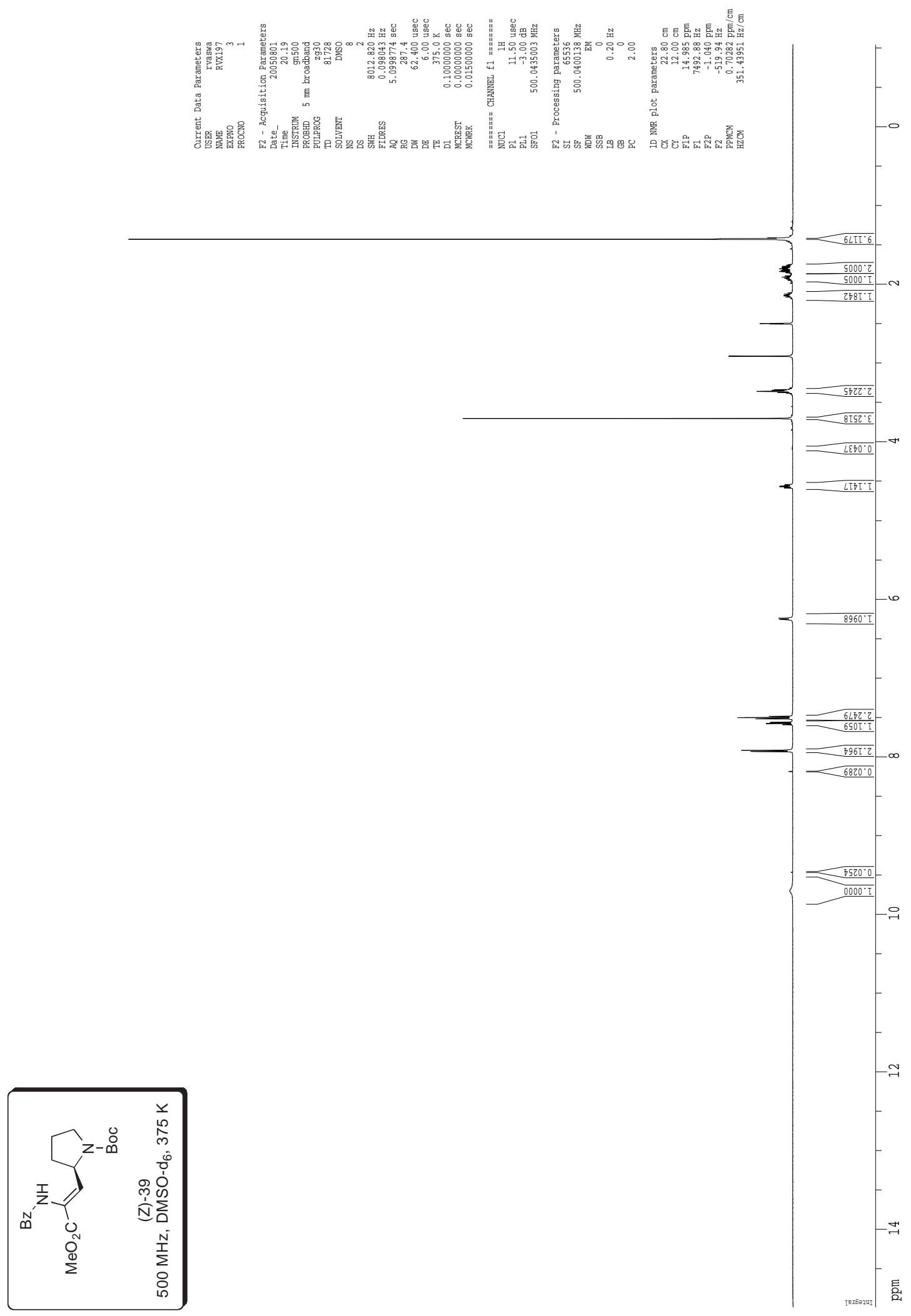

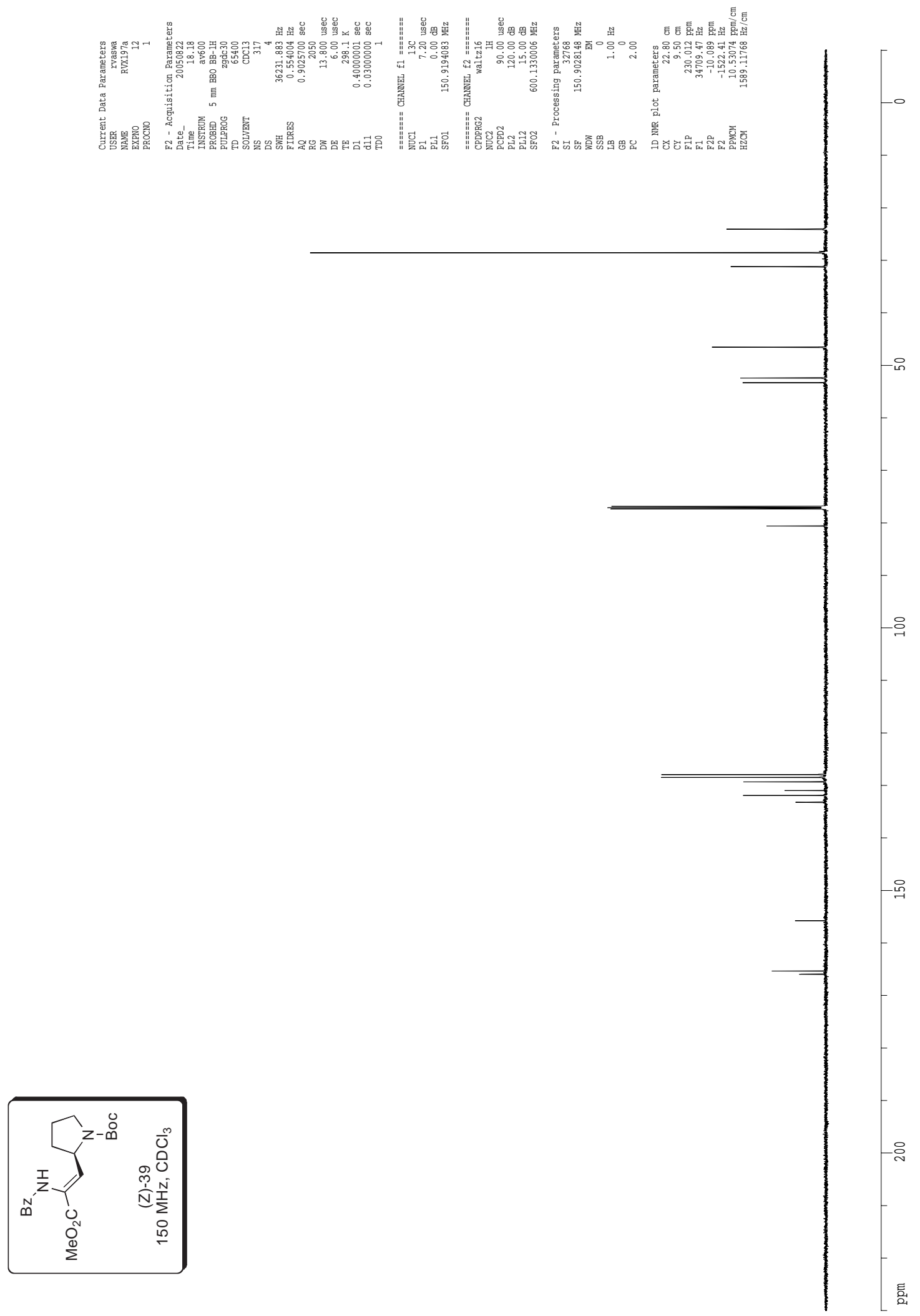

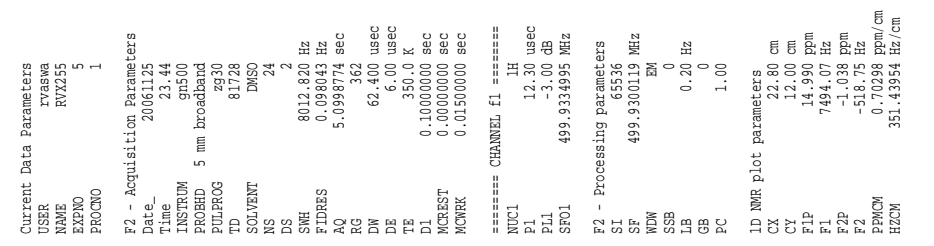

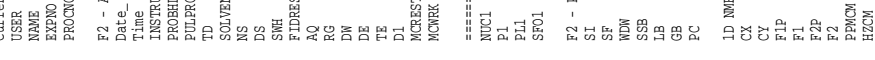

$3=\operatorname{IST0*6}^{\circ}$

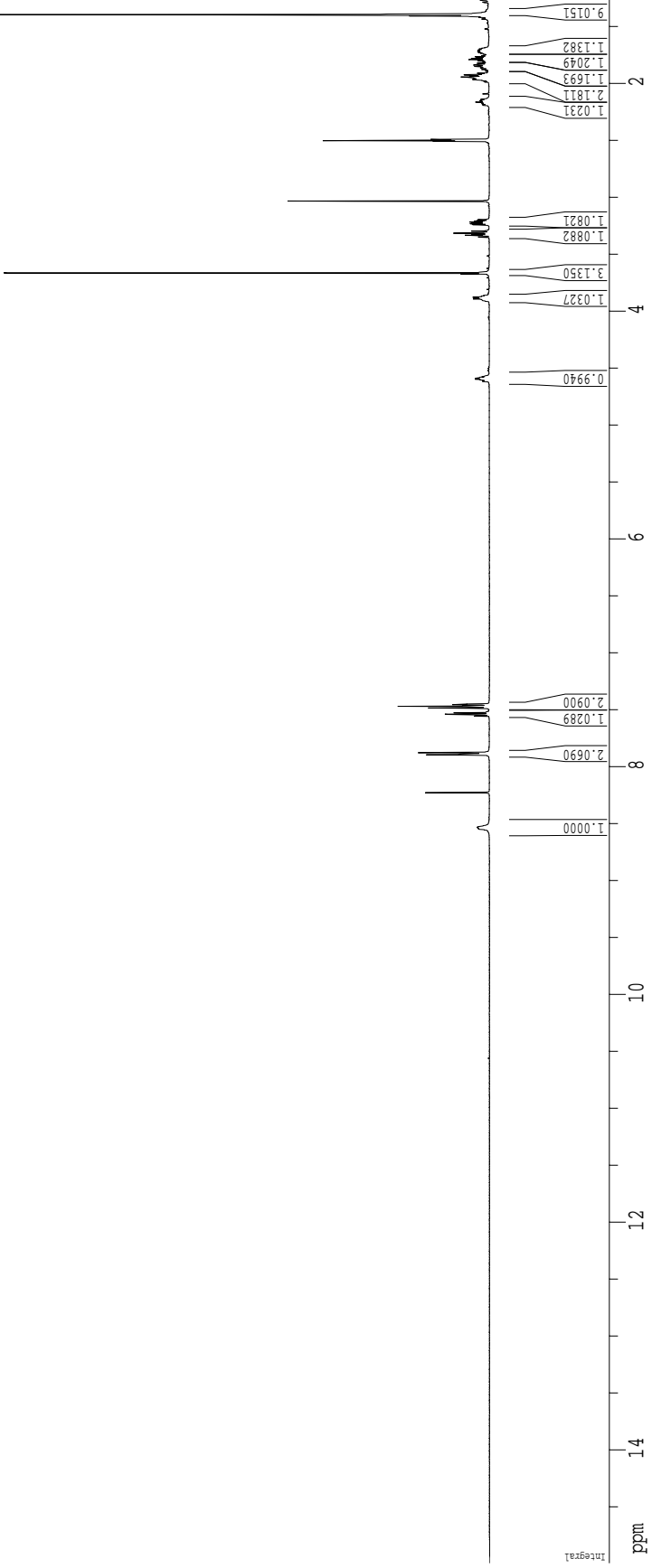




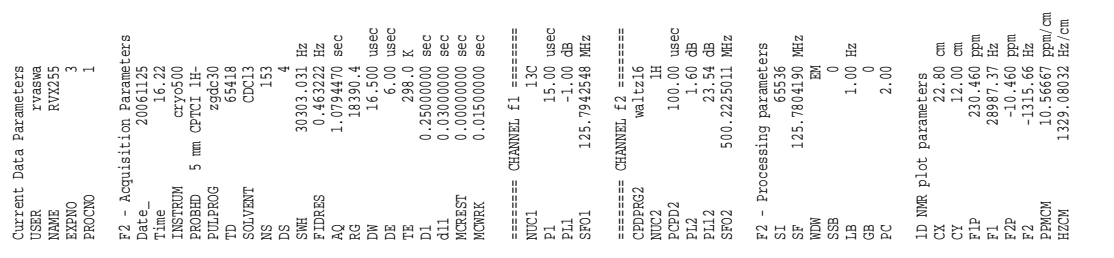




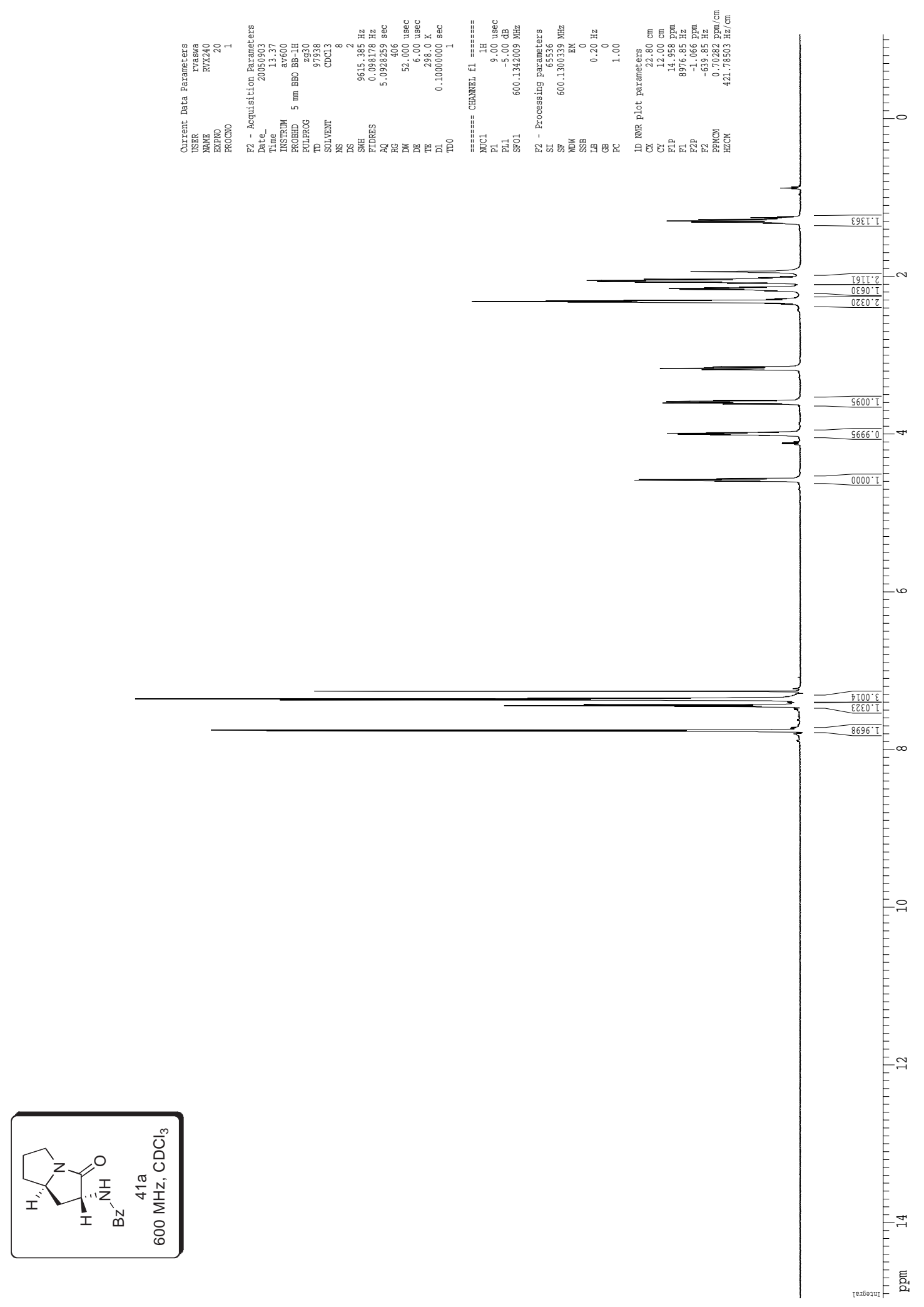




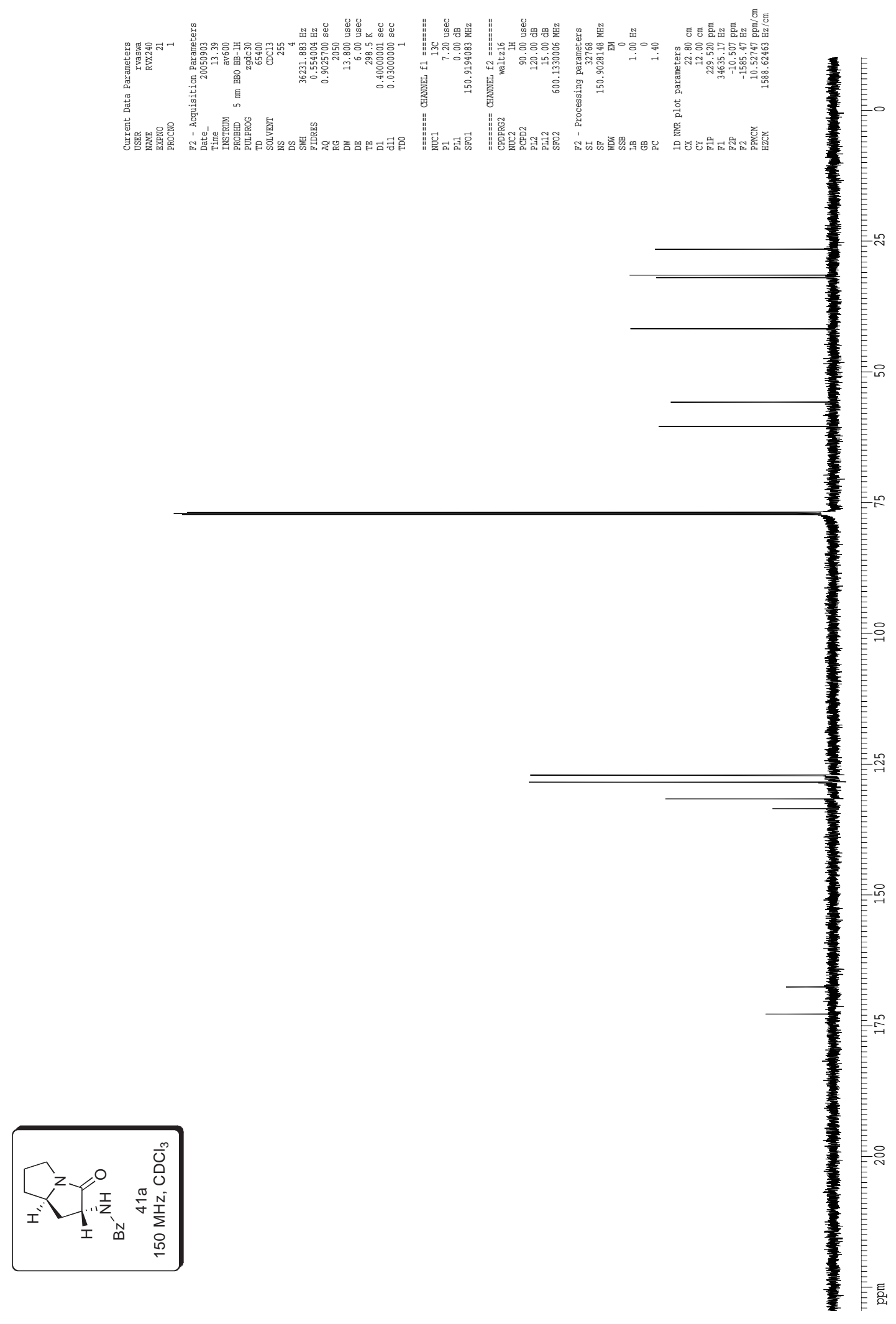




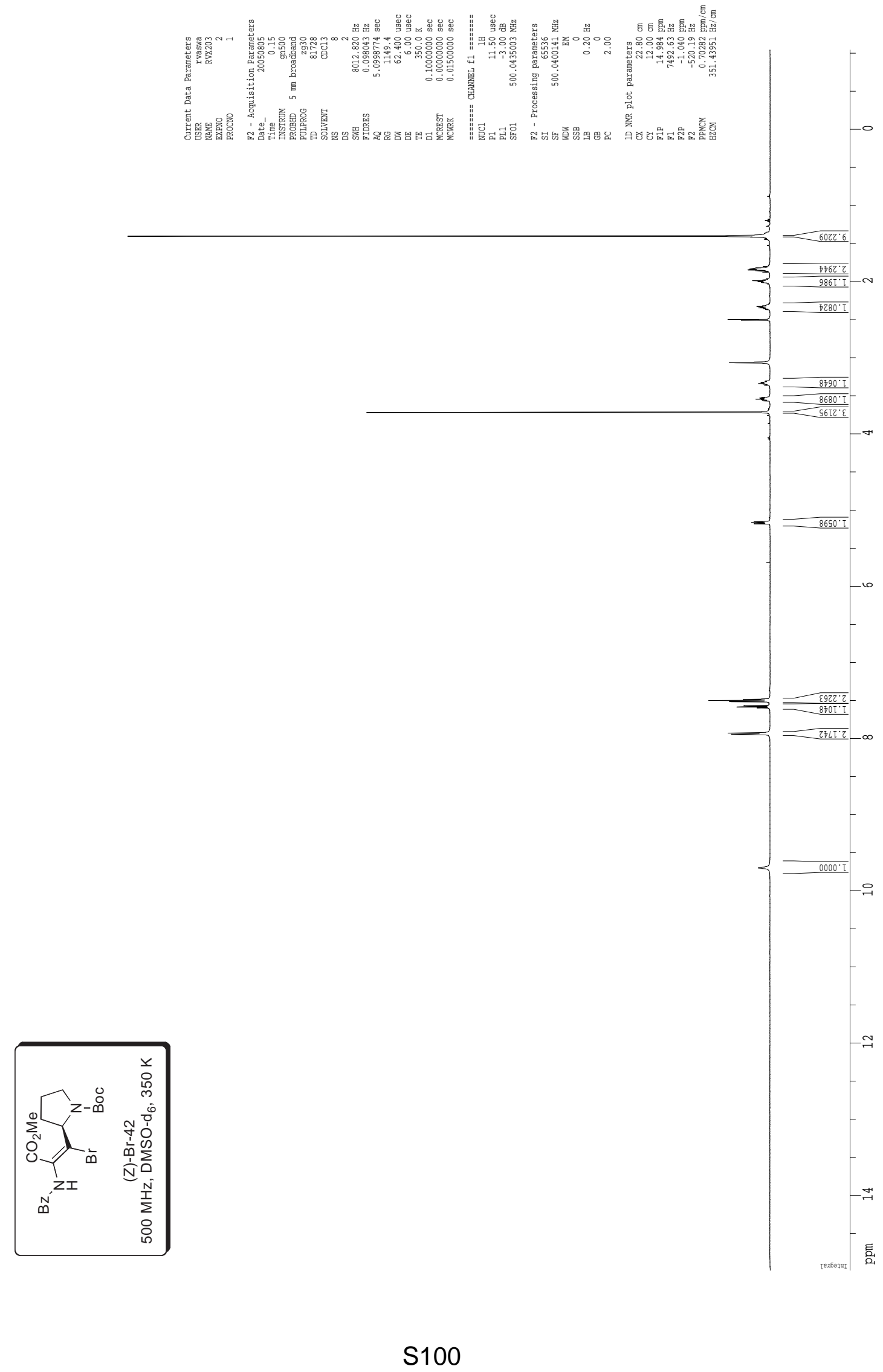



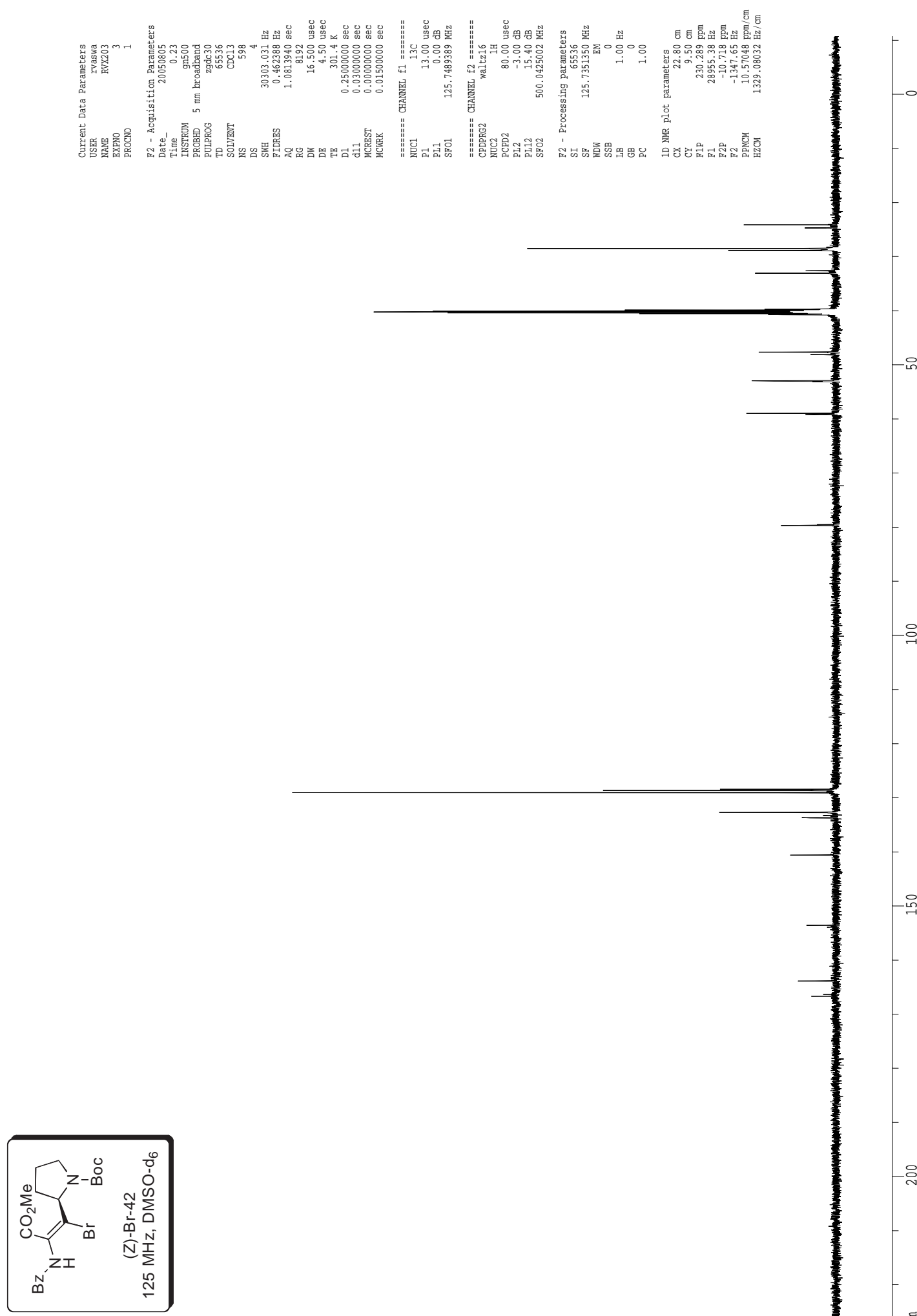


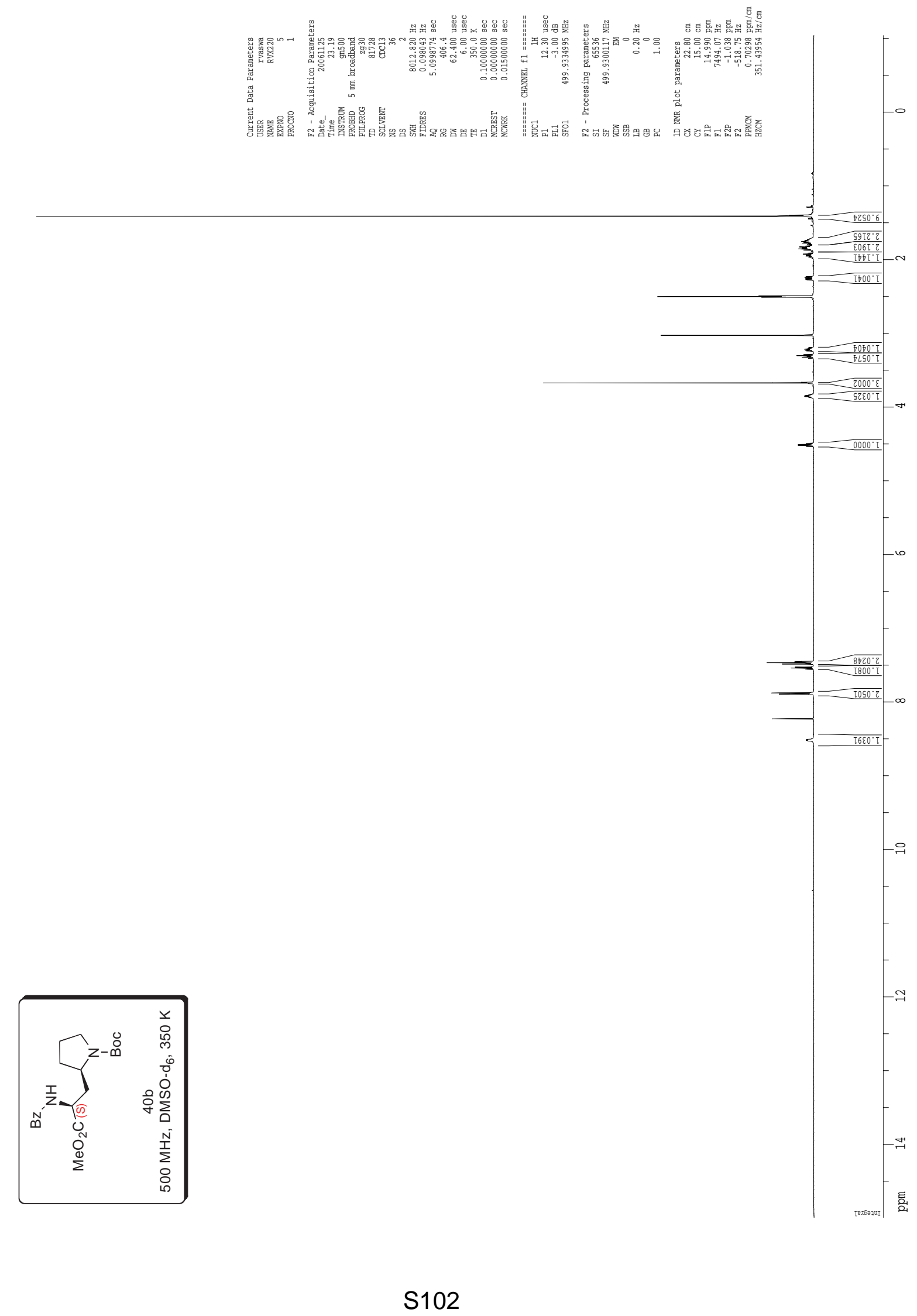



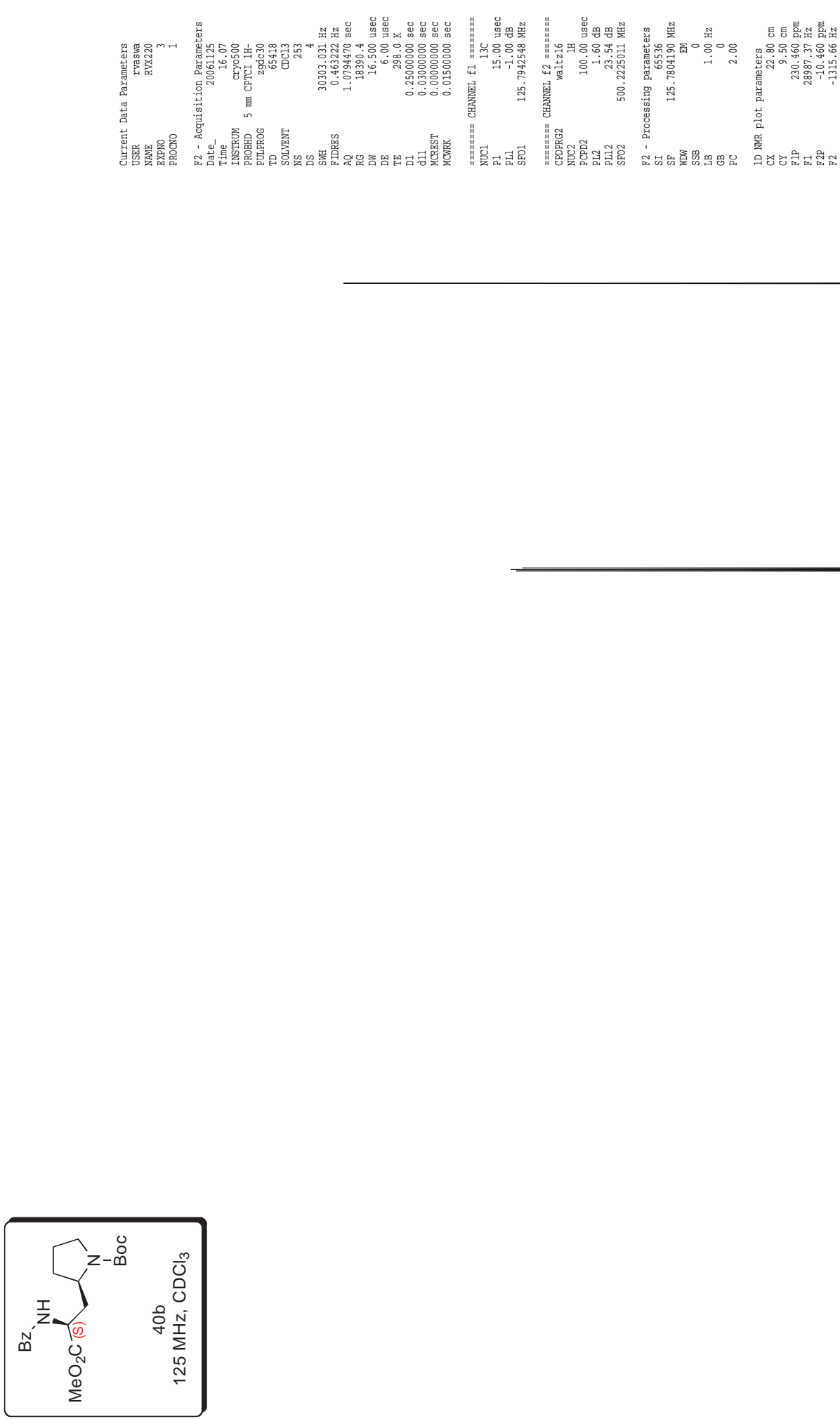


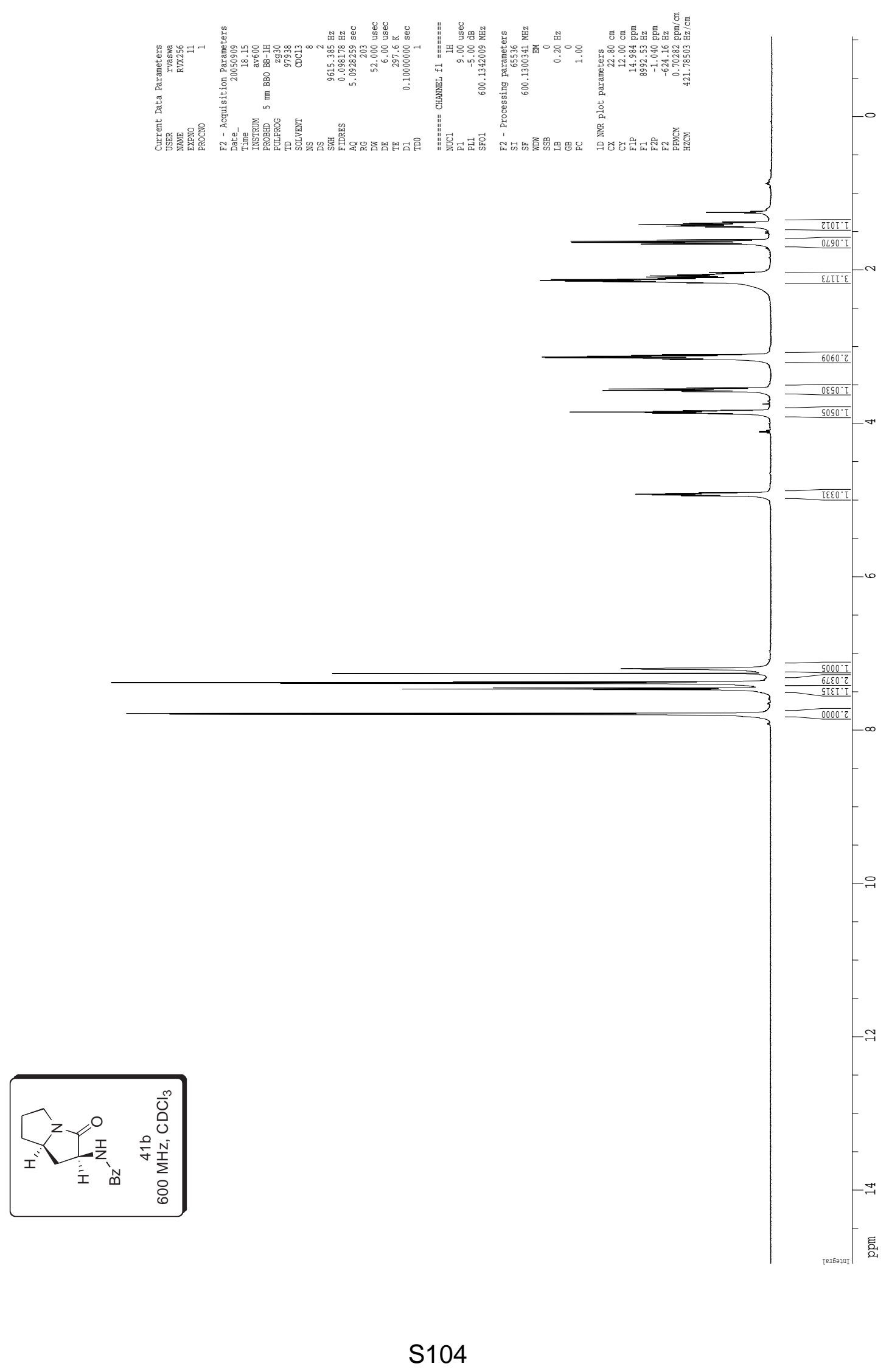



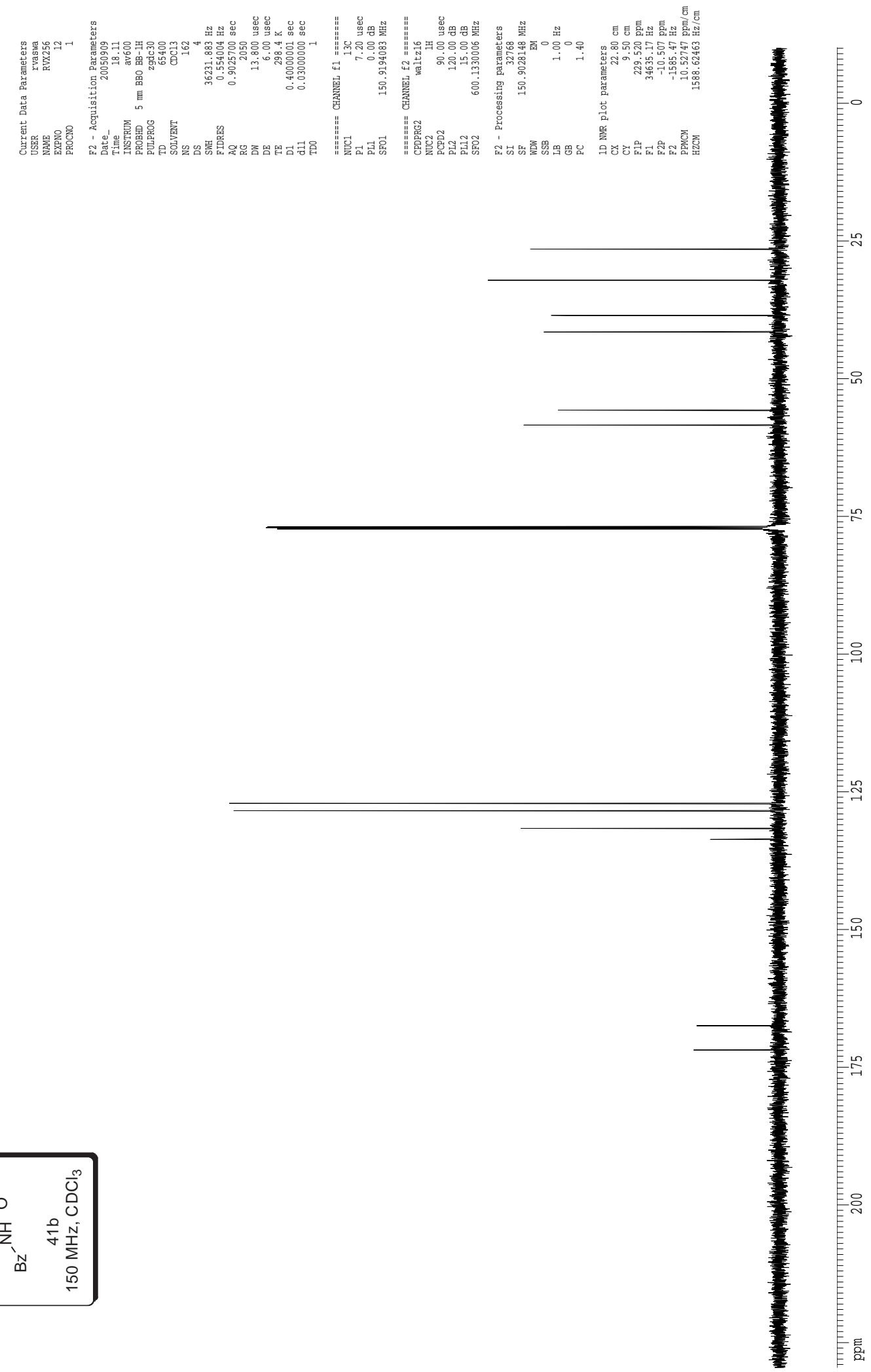


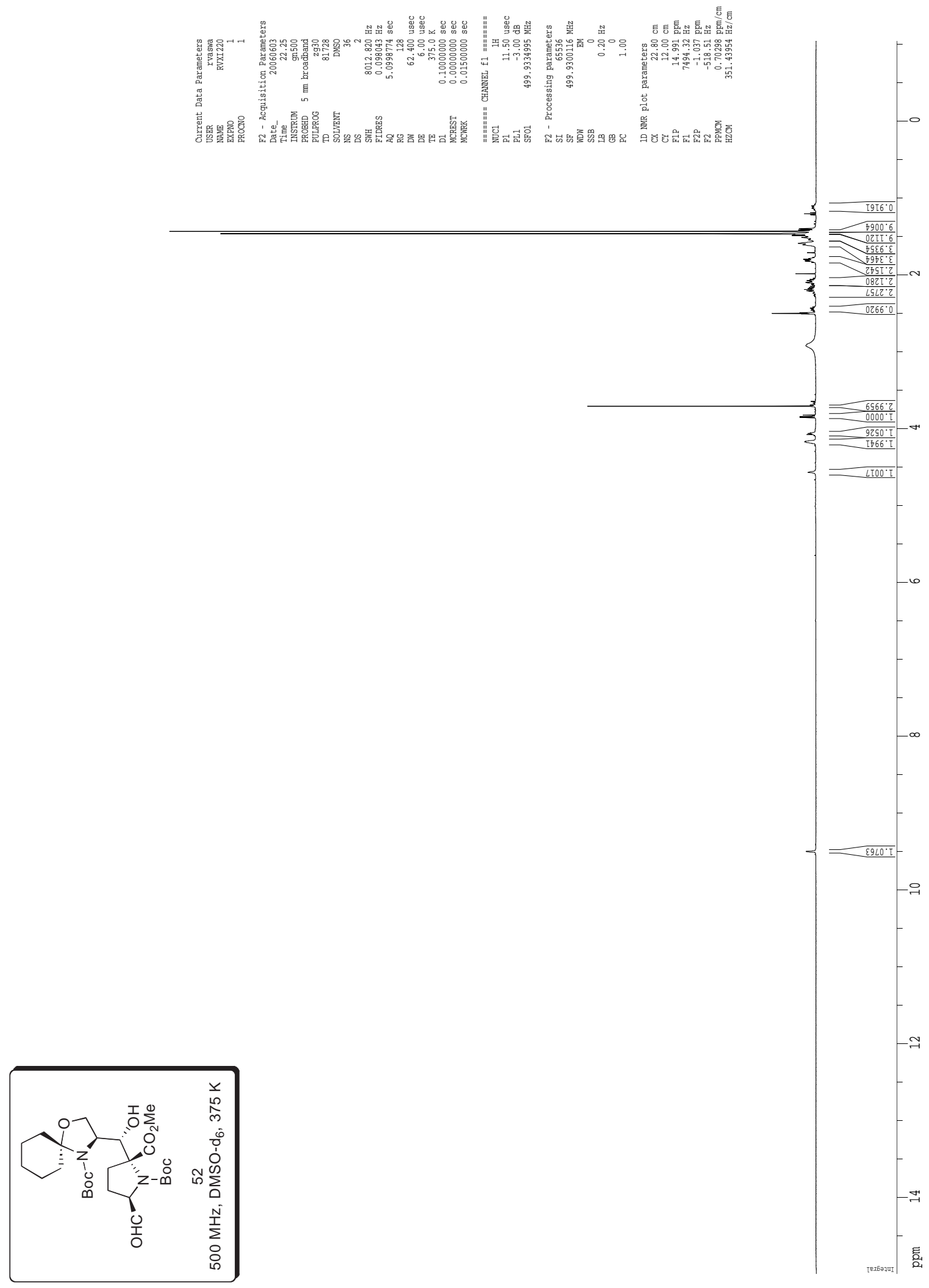




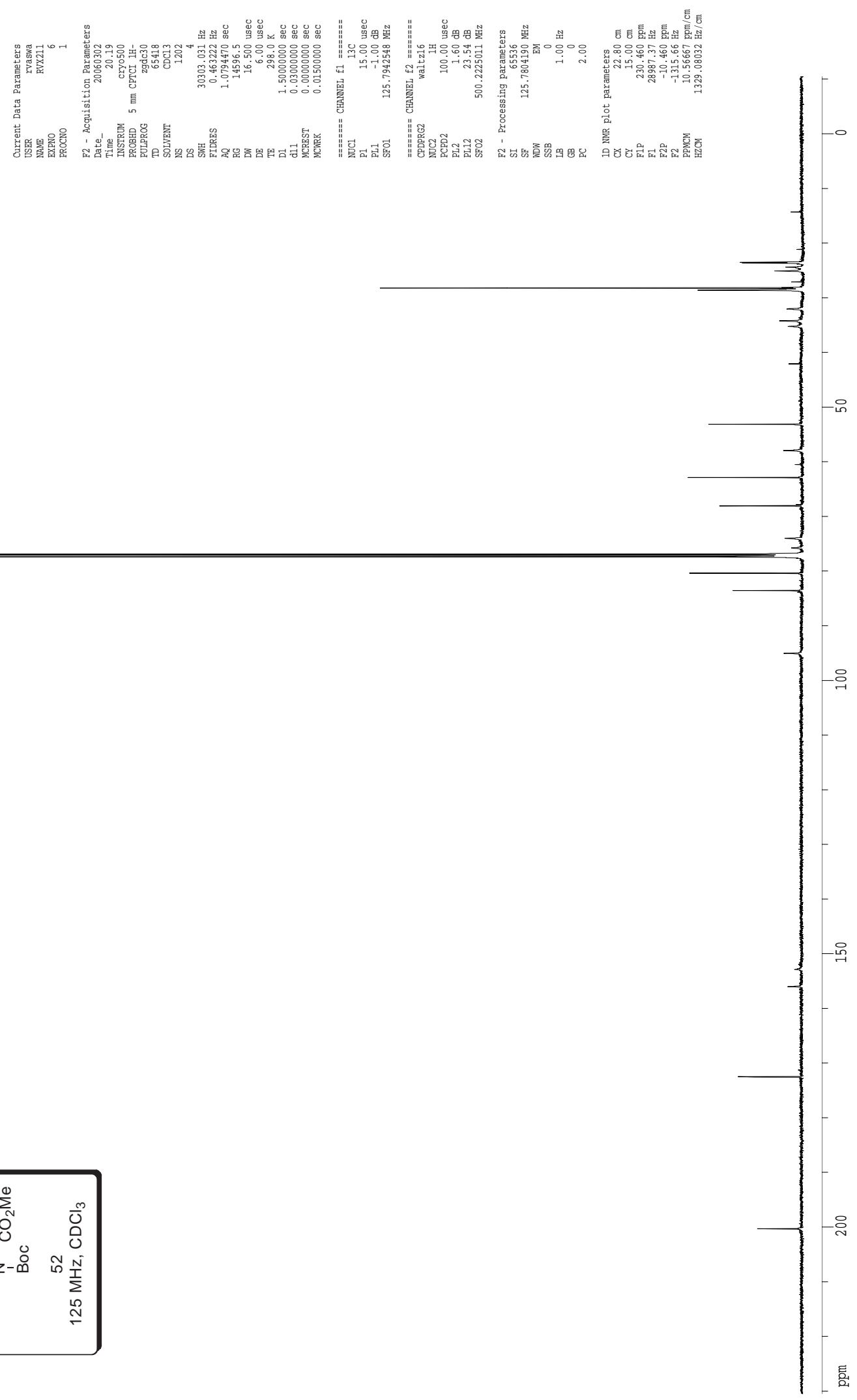




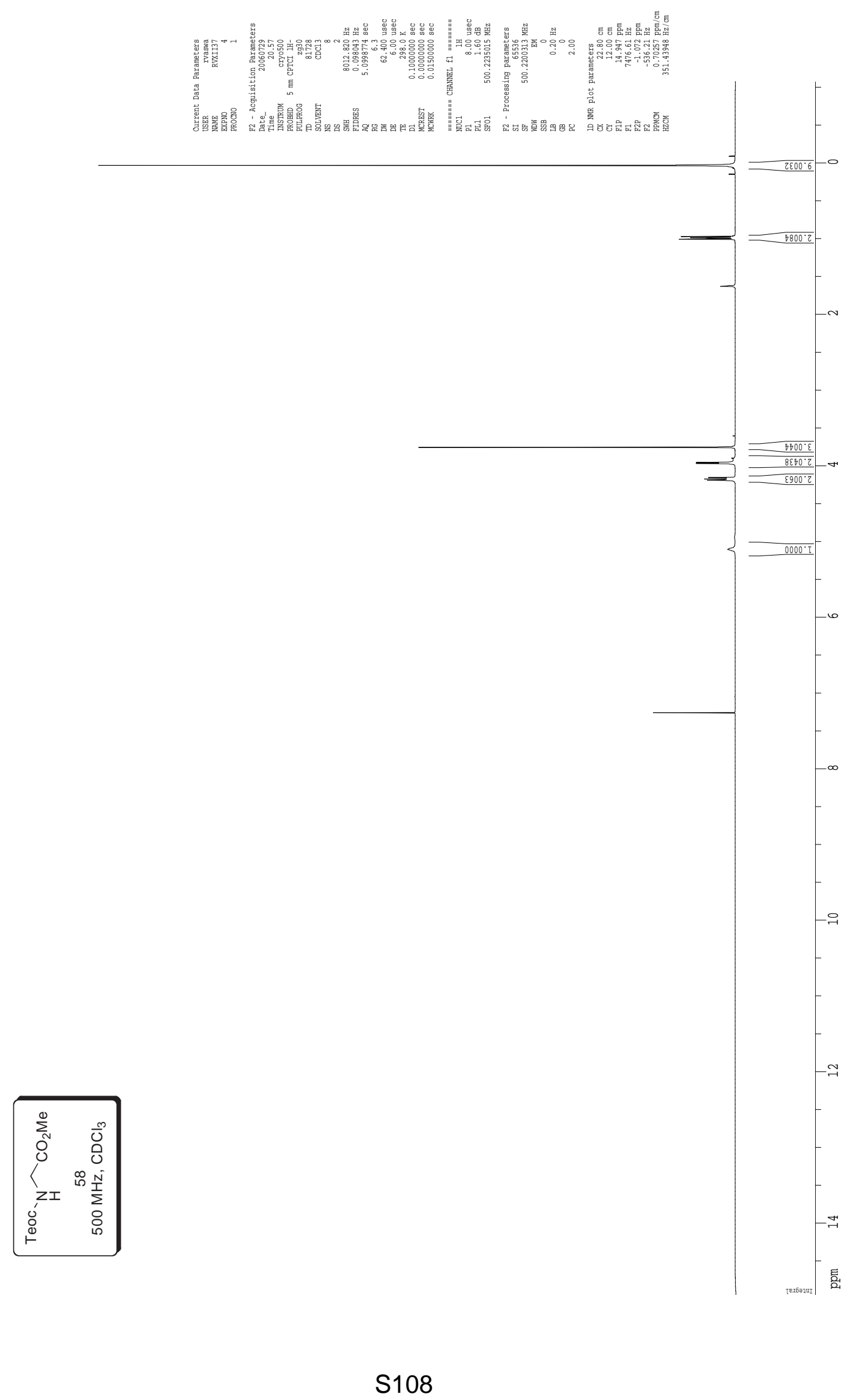




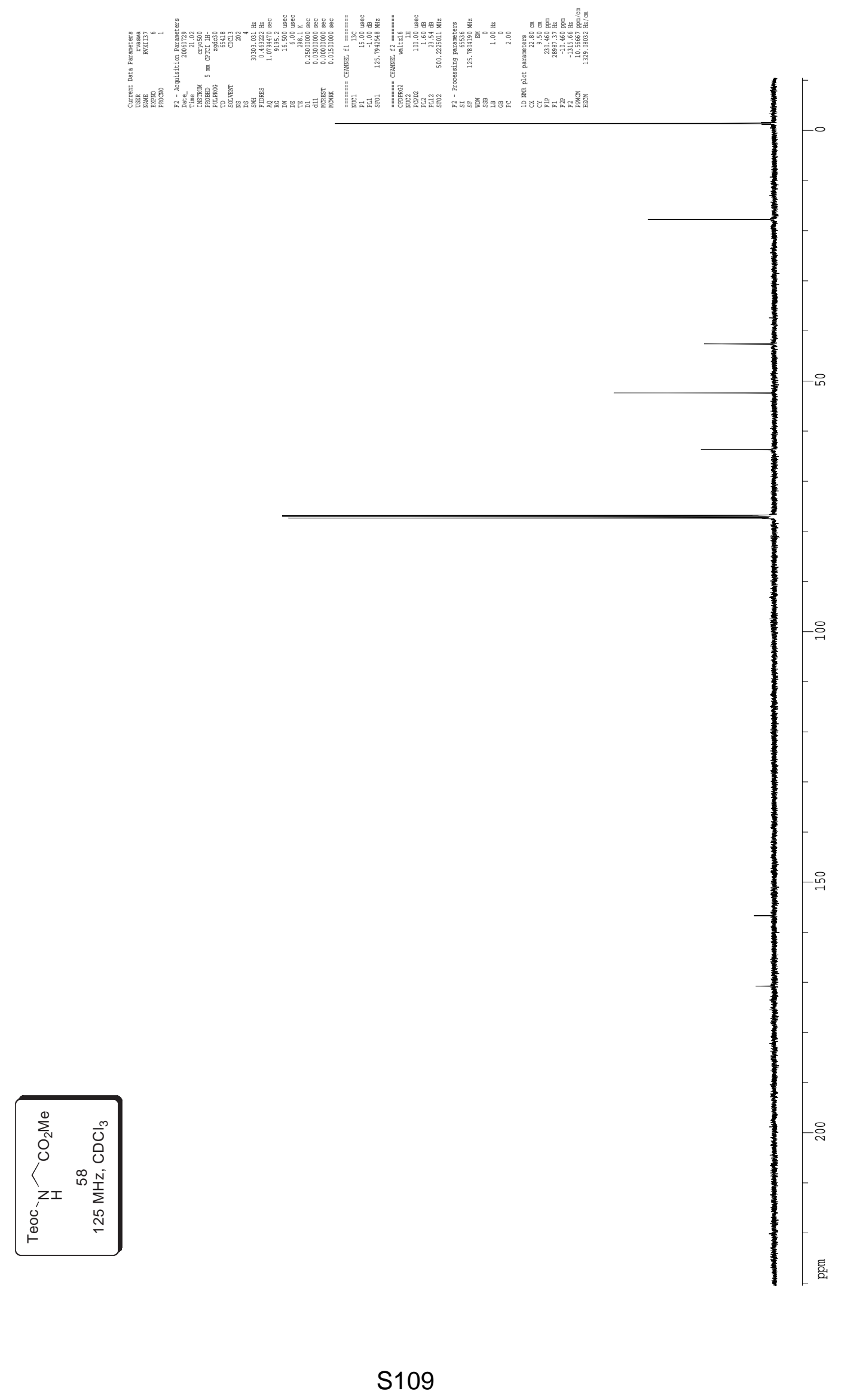




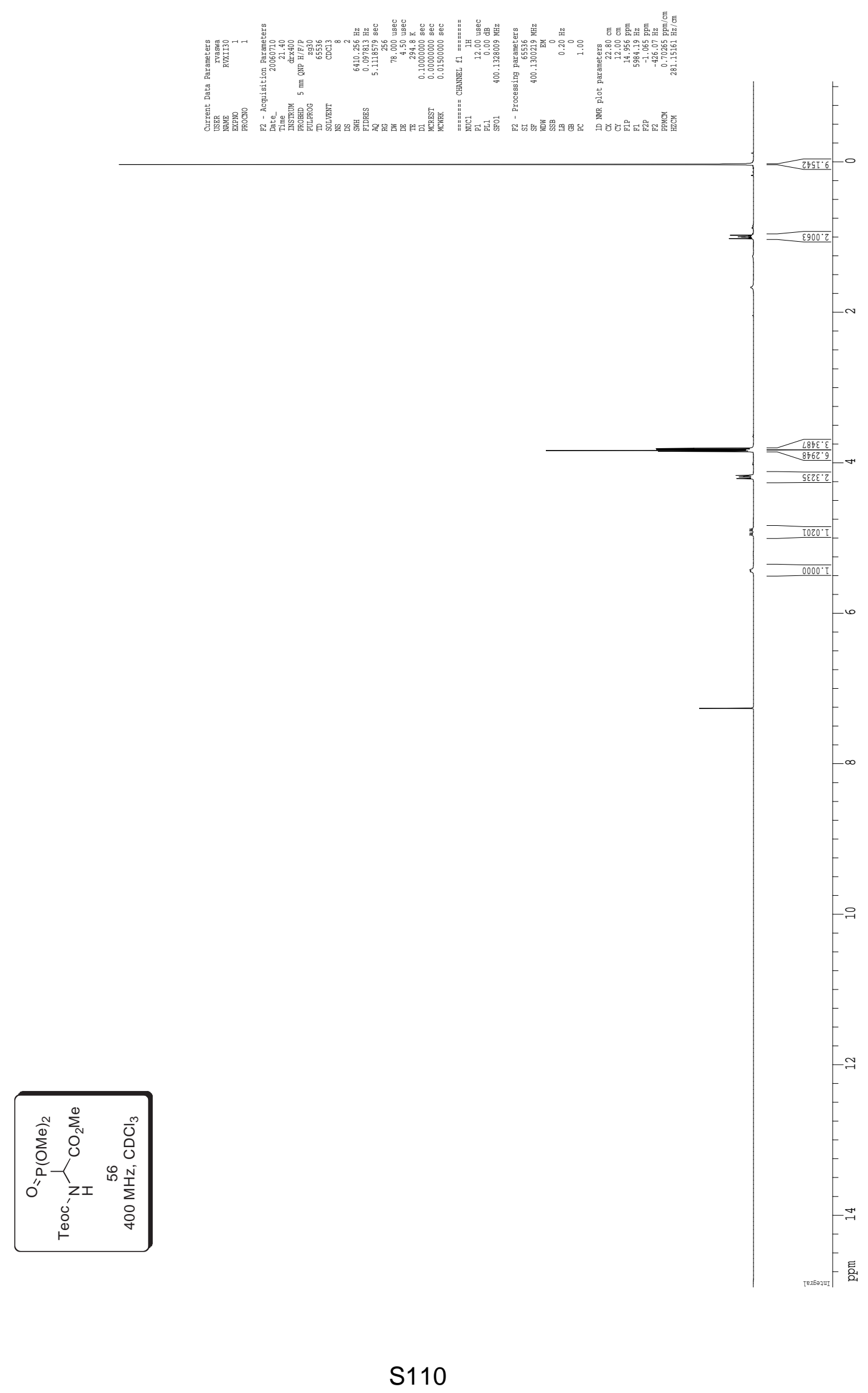




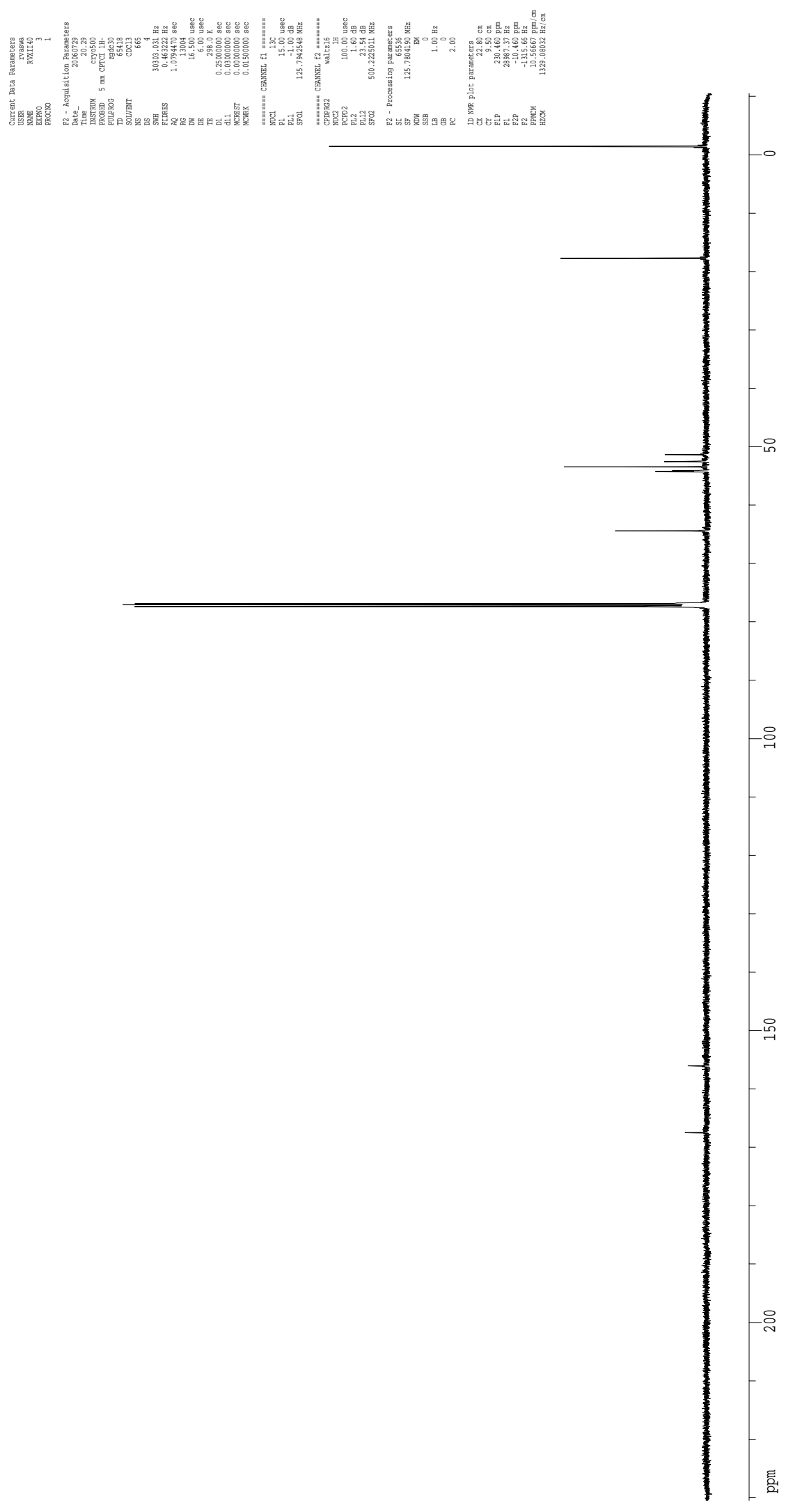




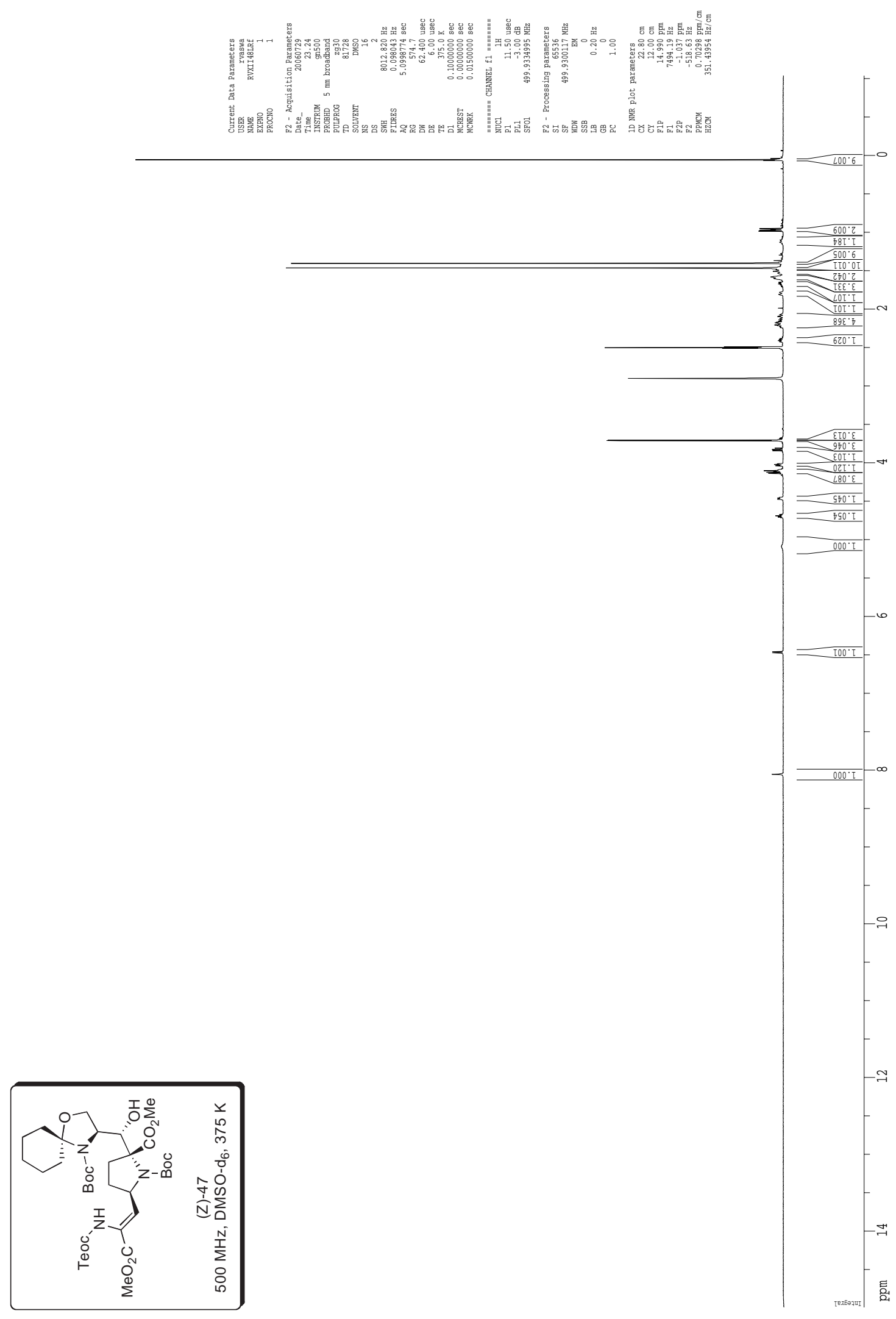




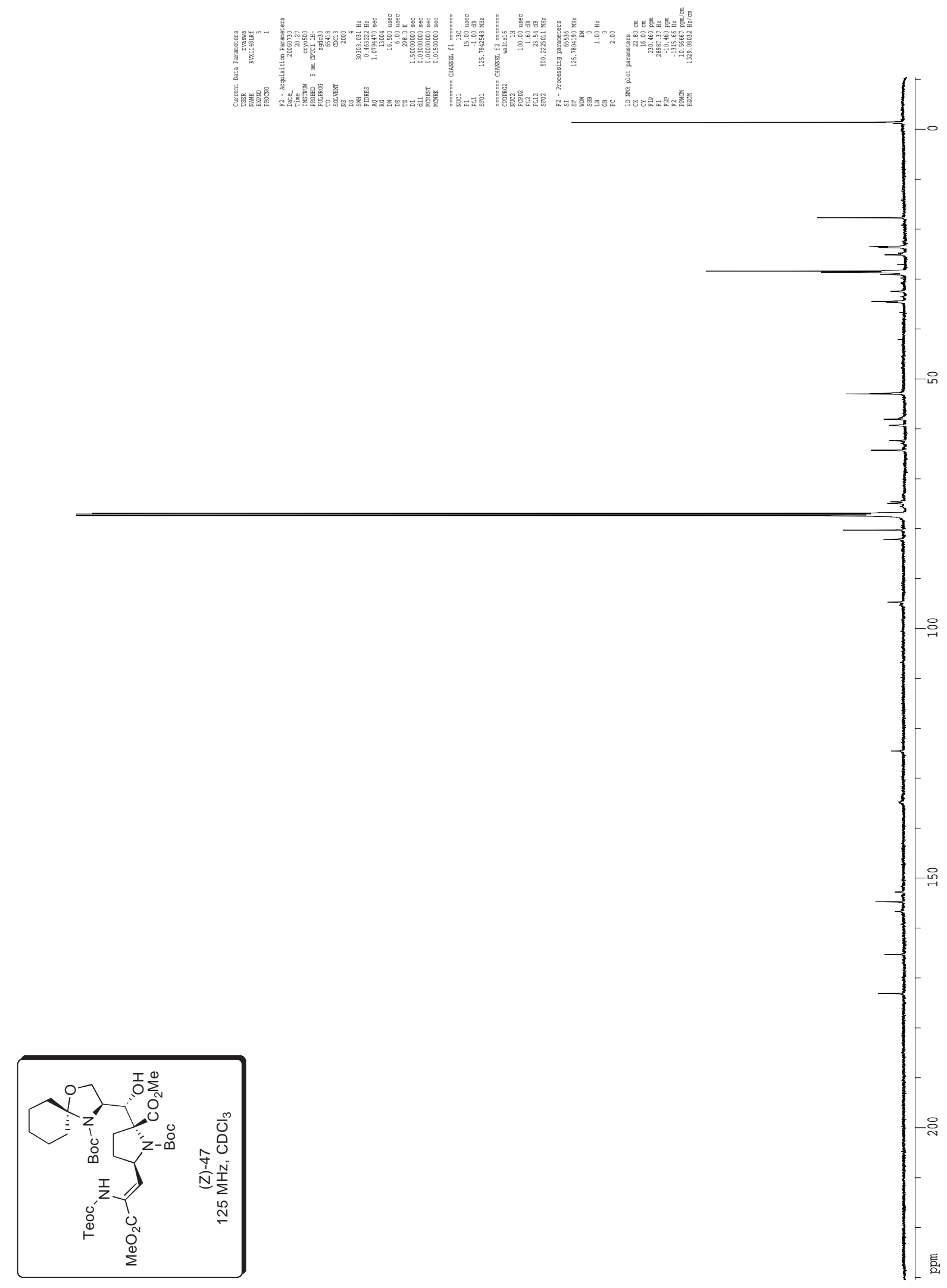




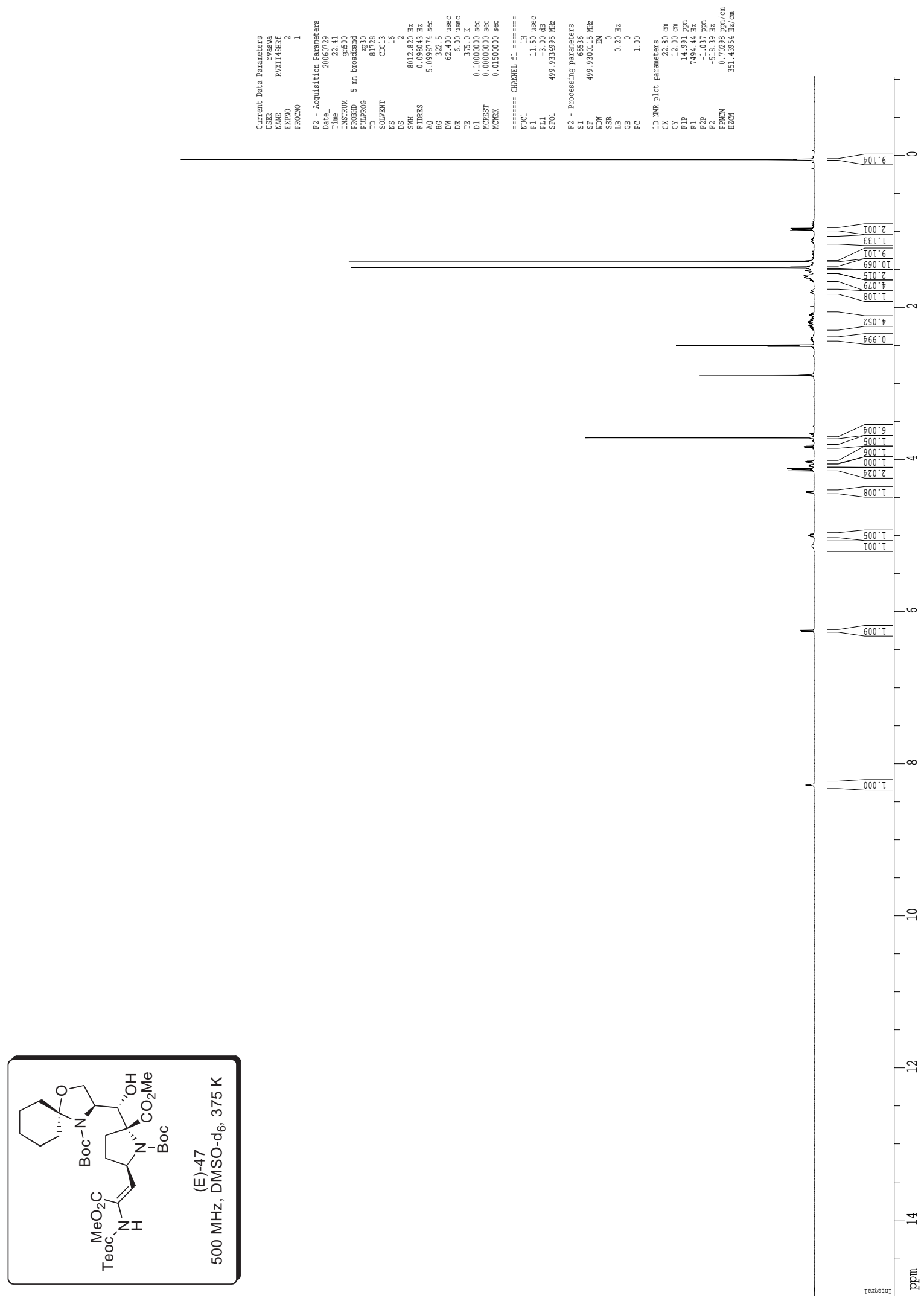




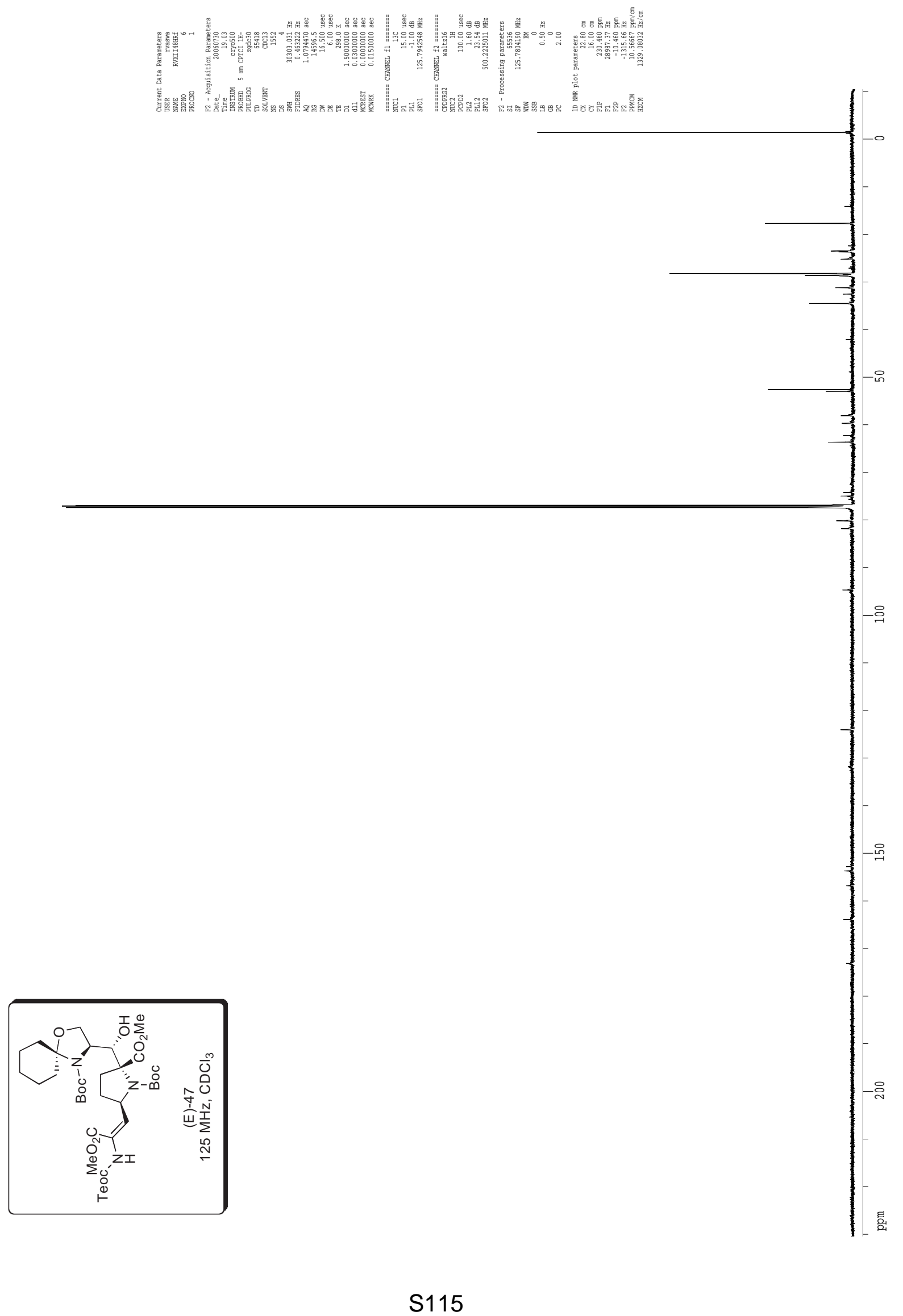




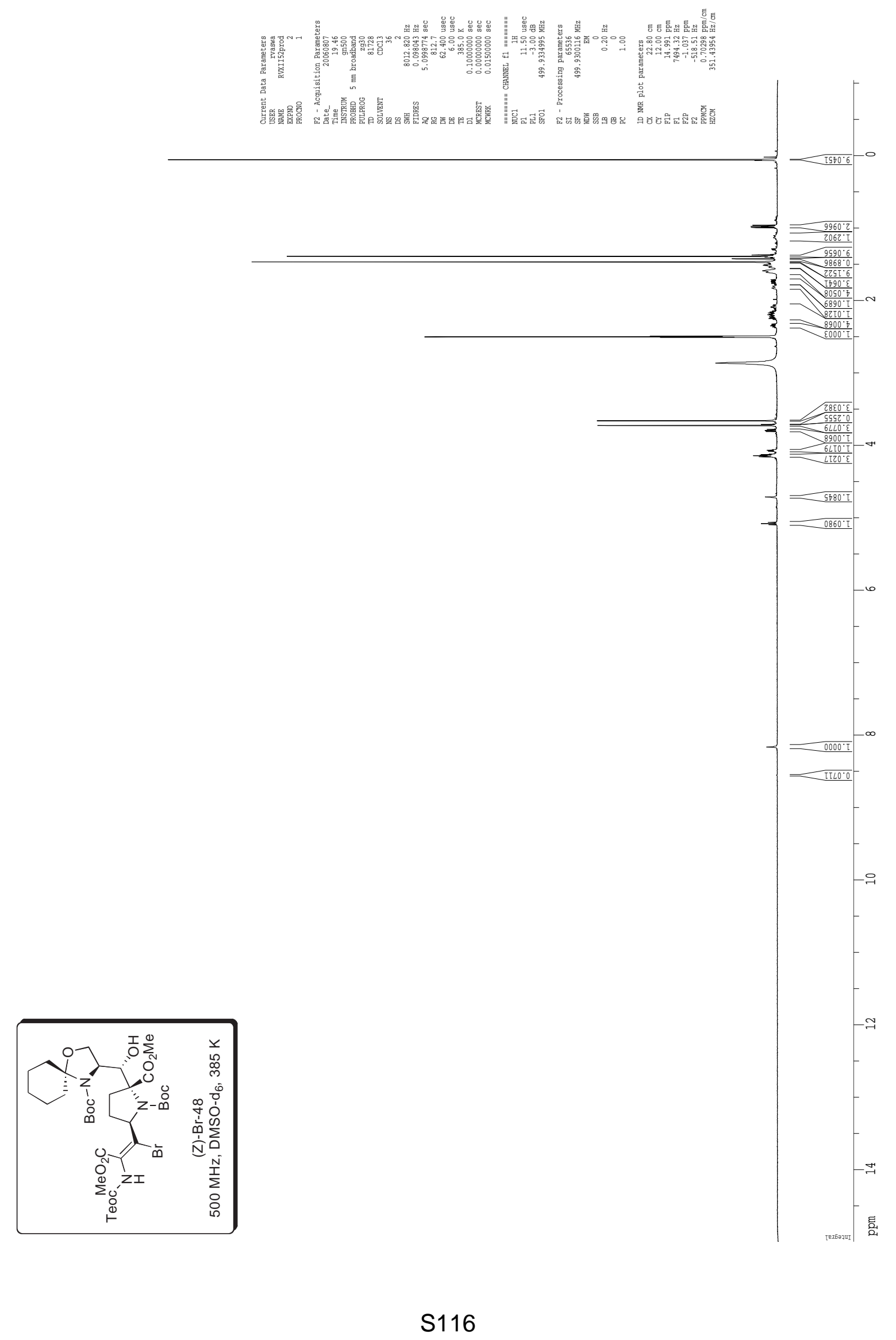




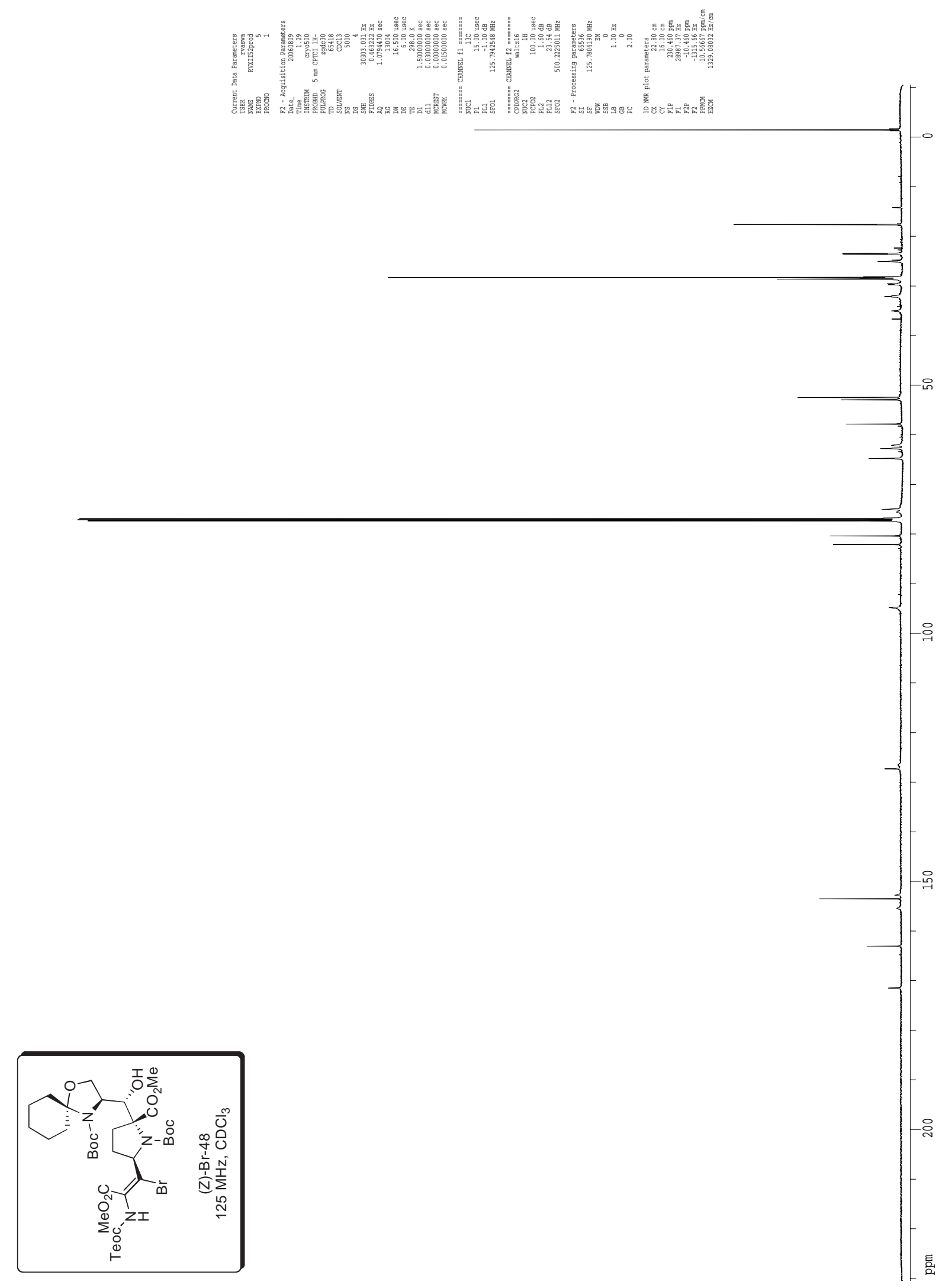




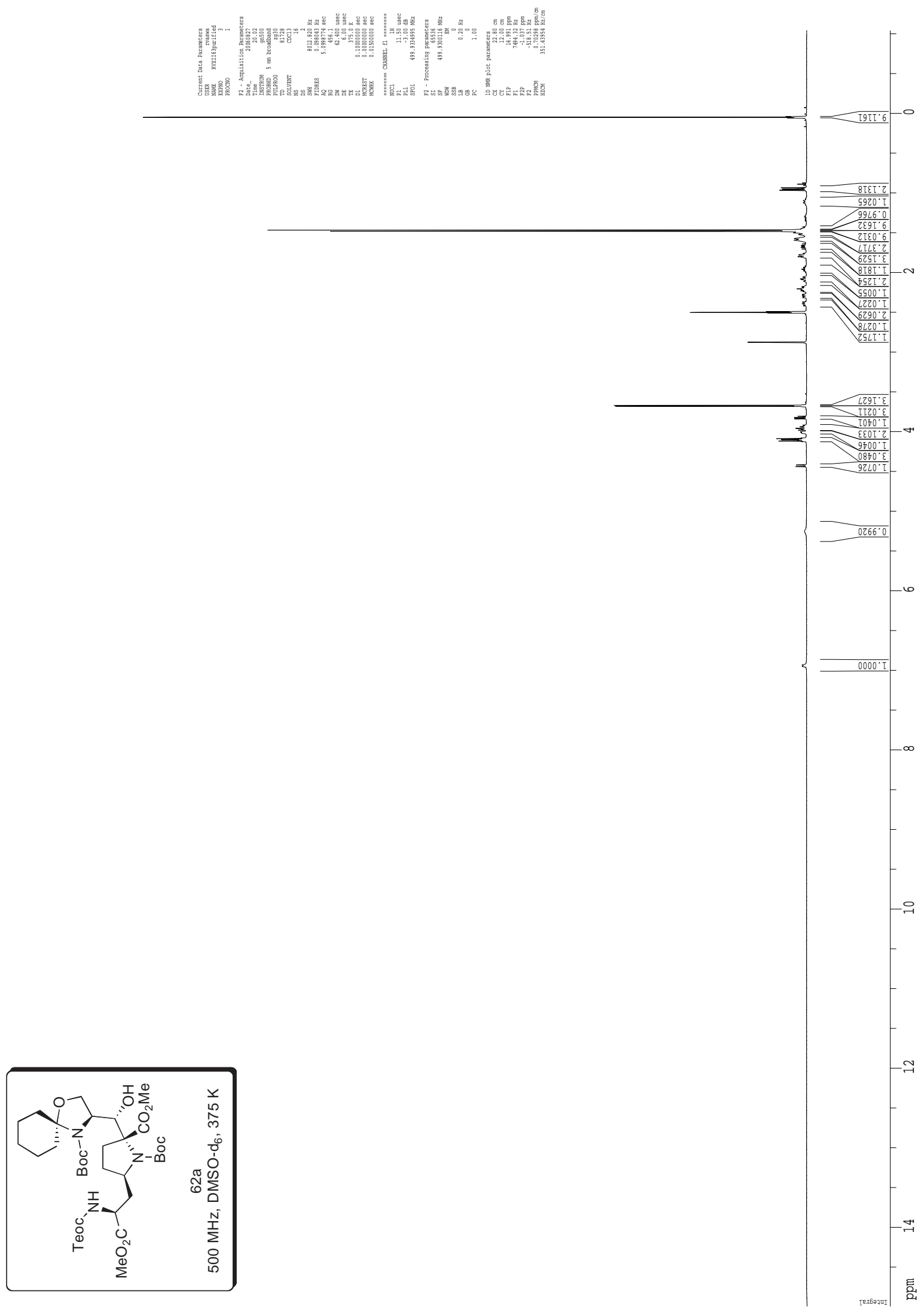




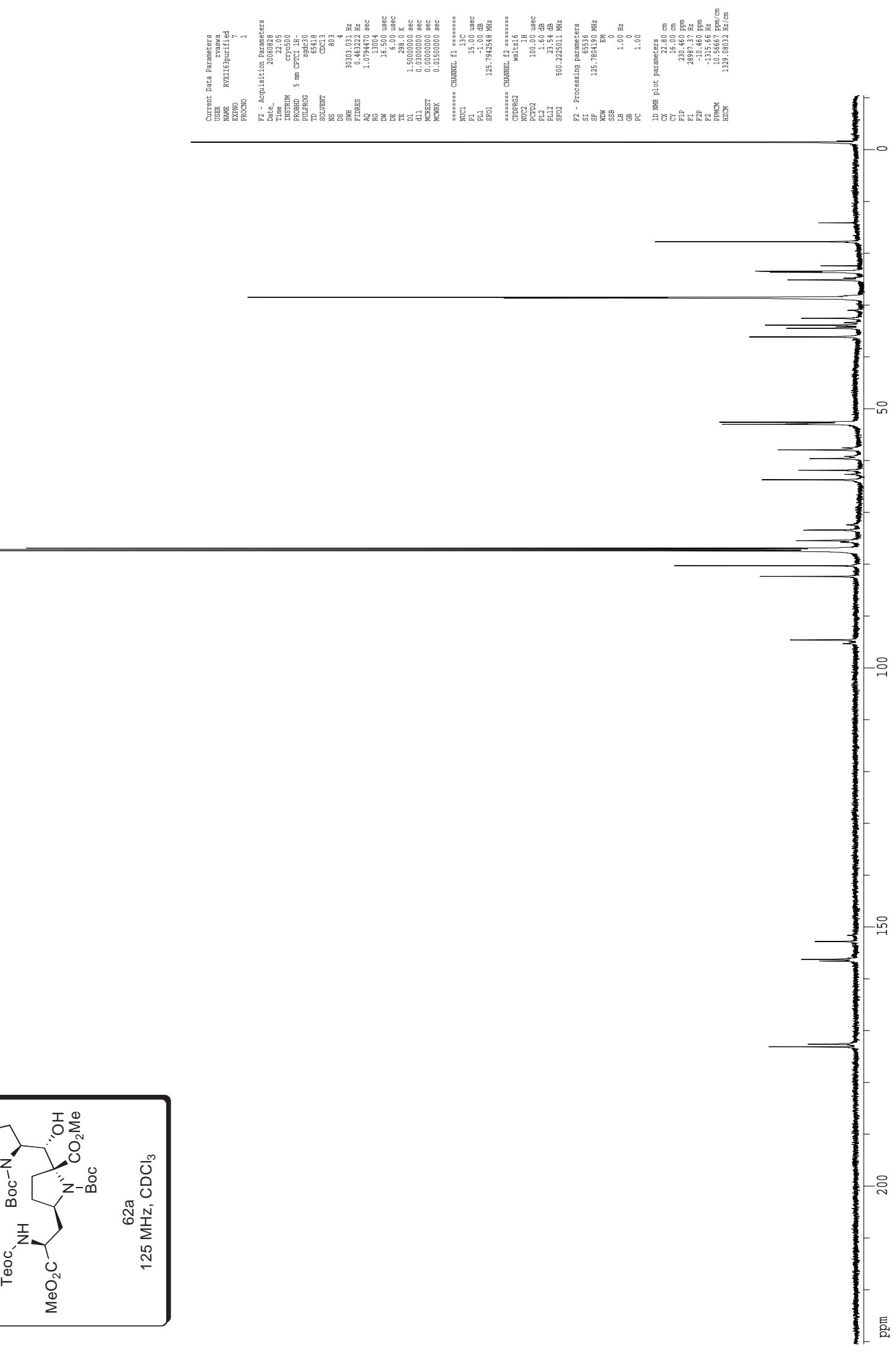




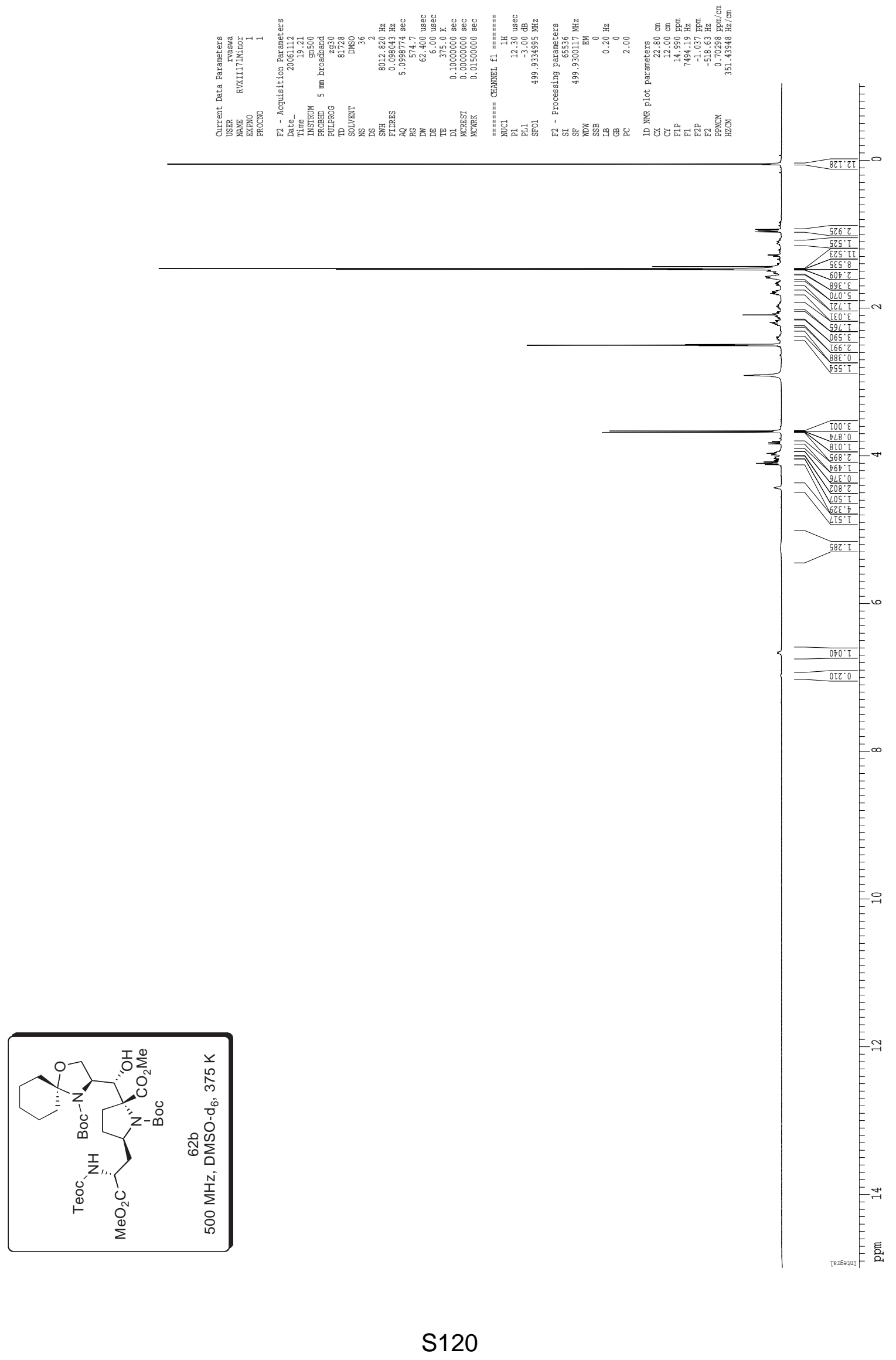




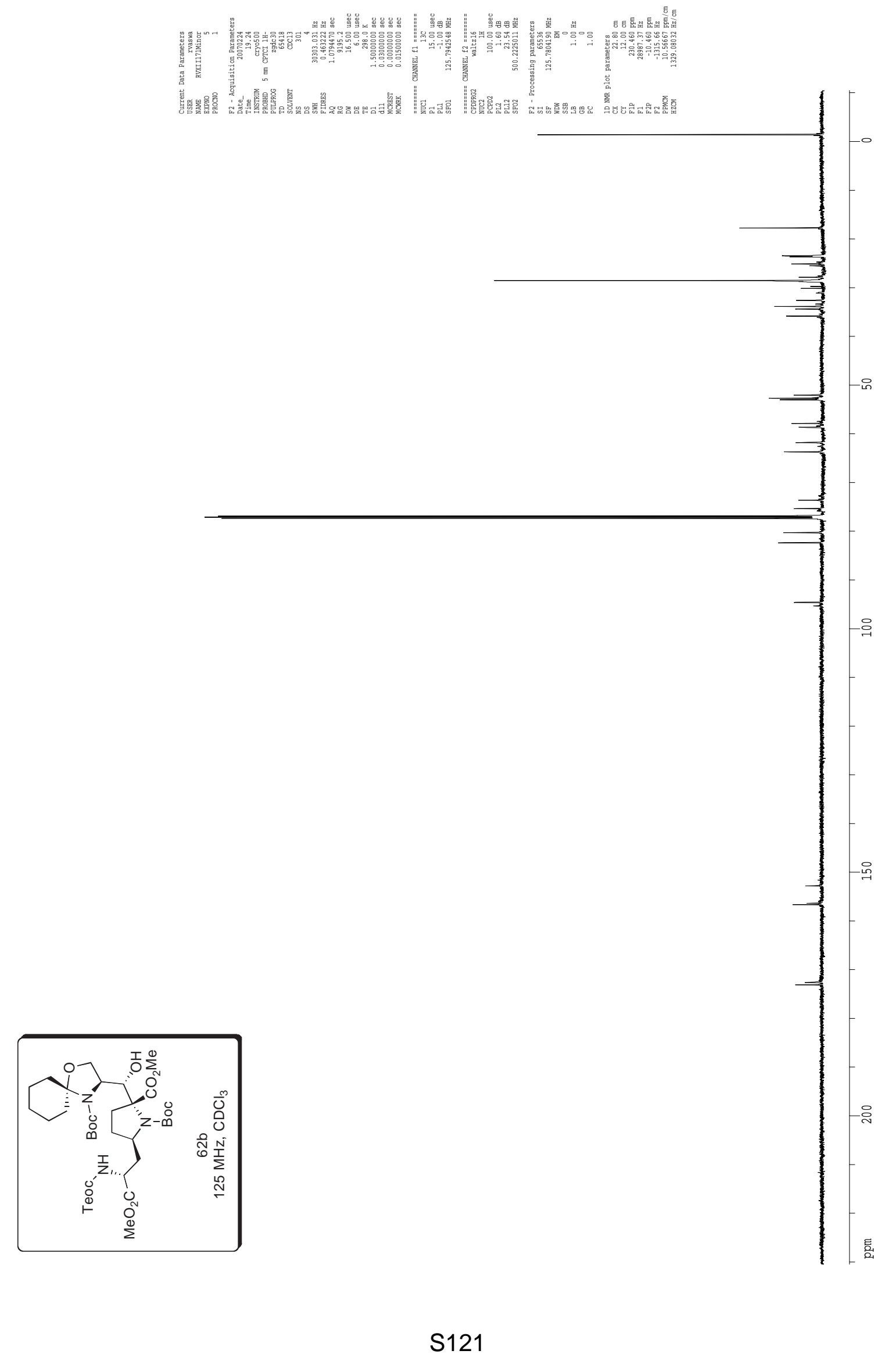



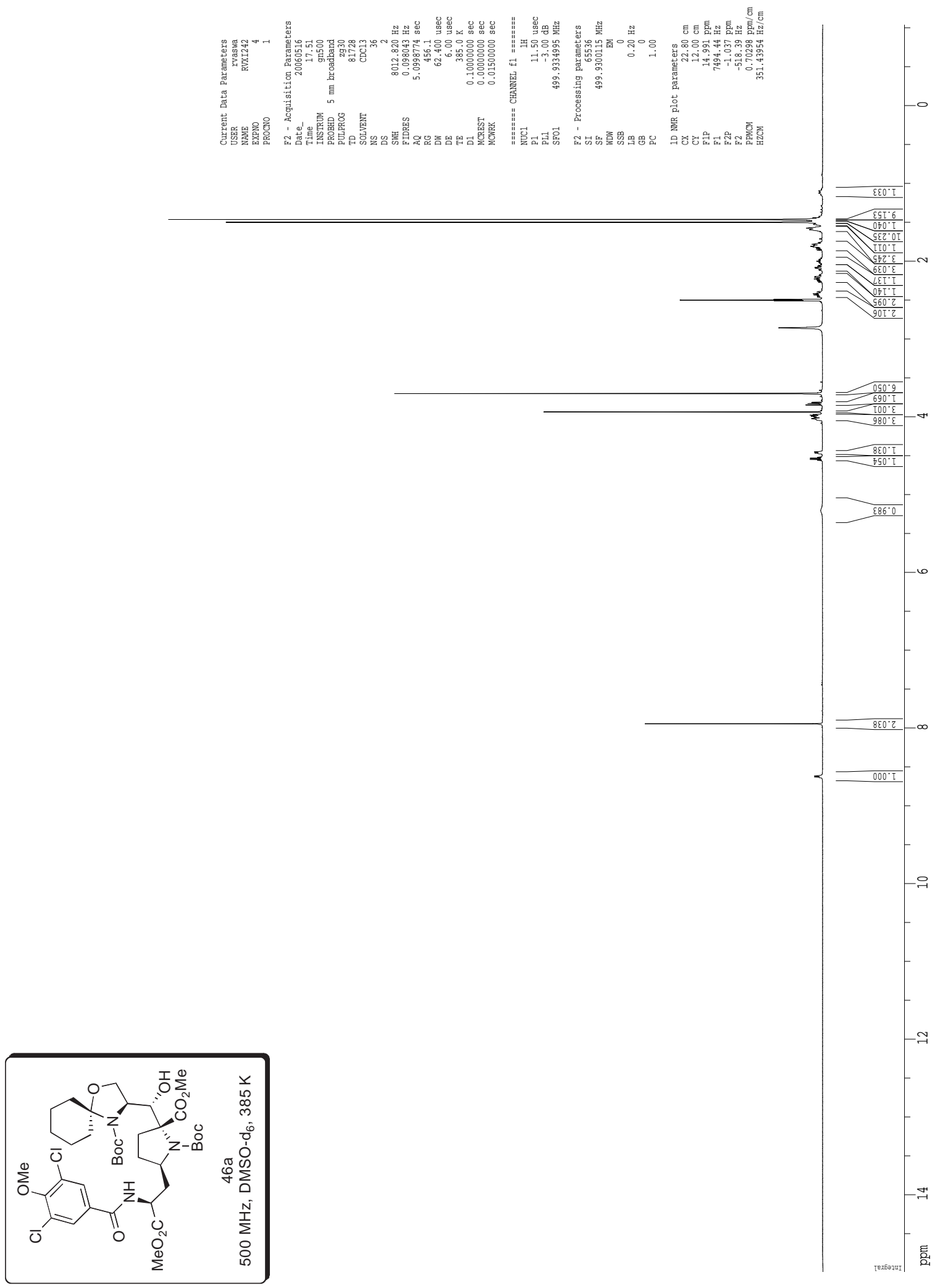


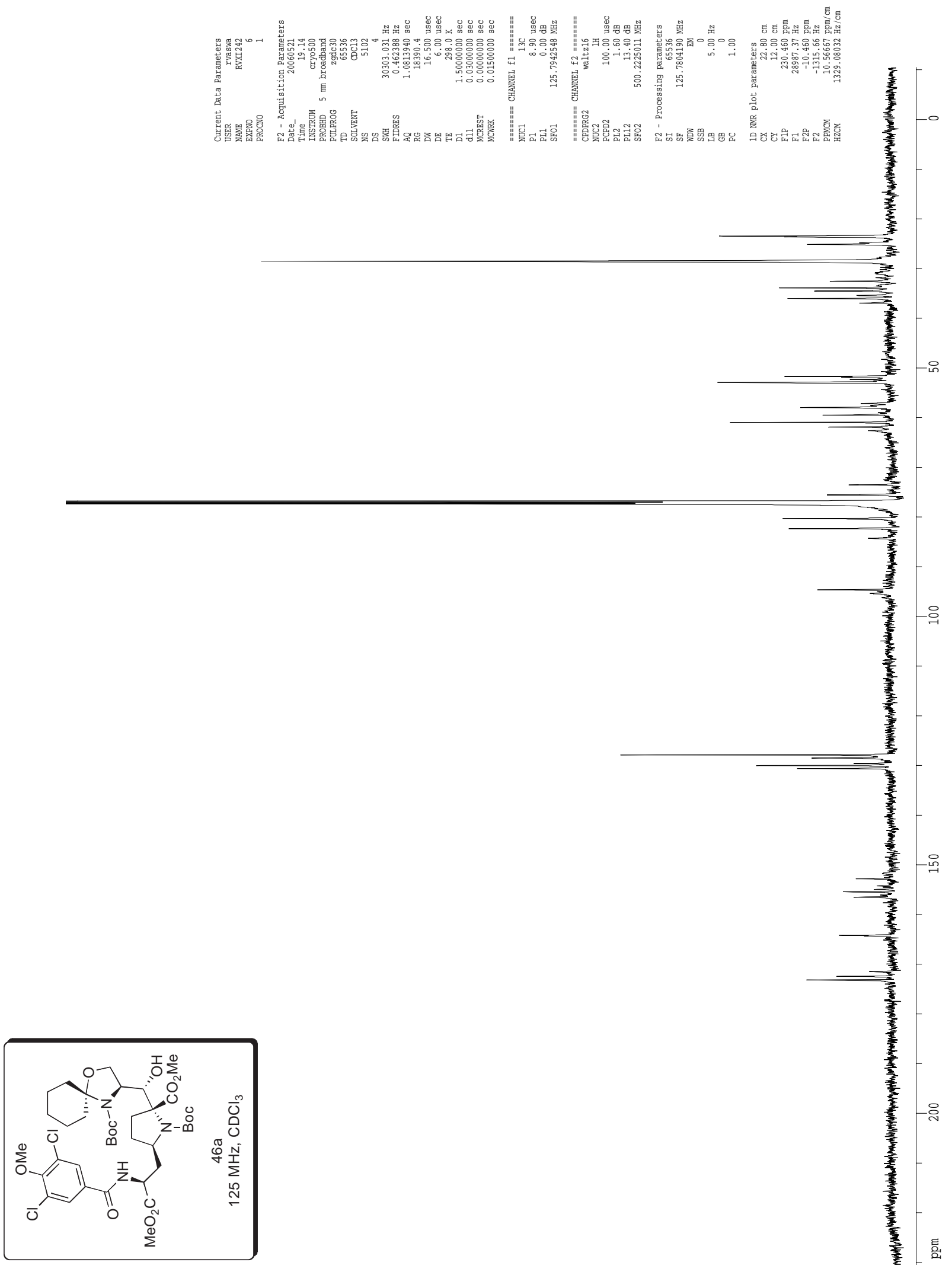



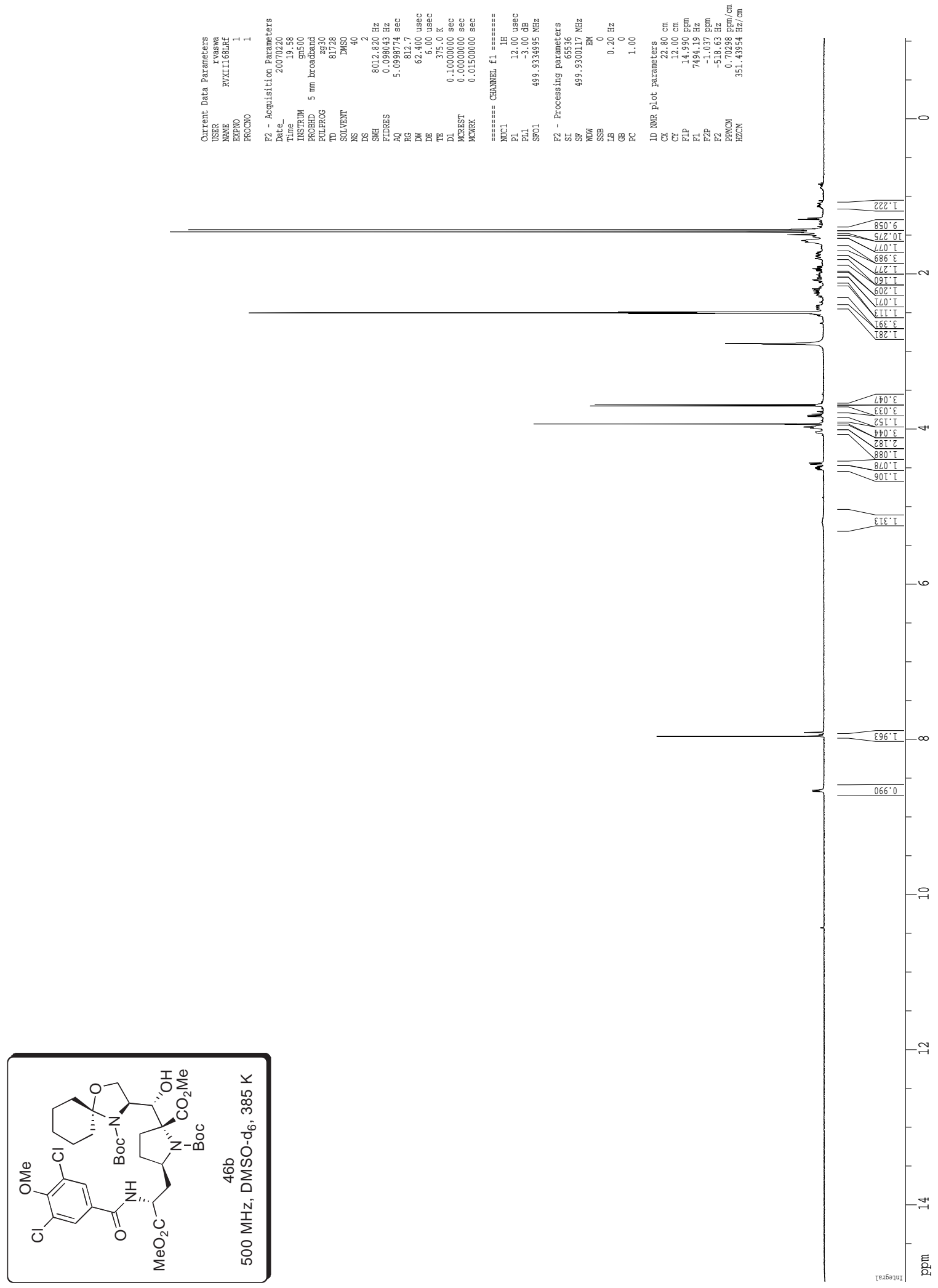

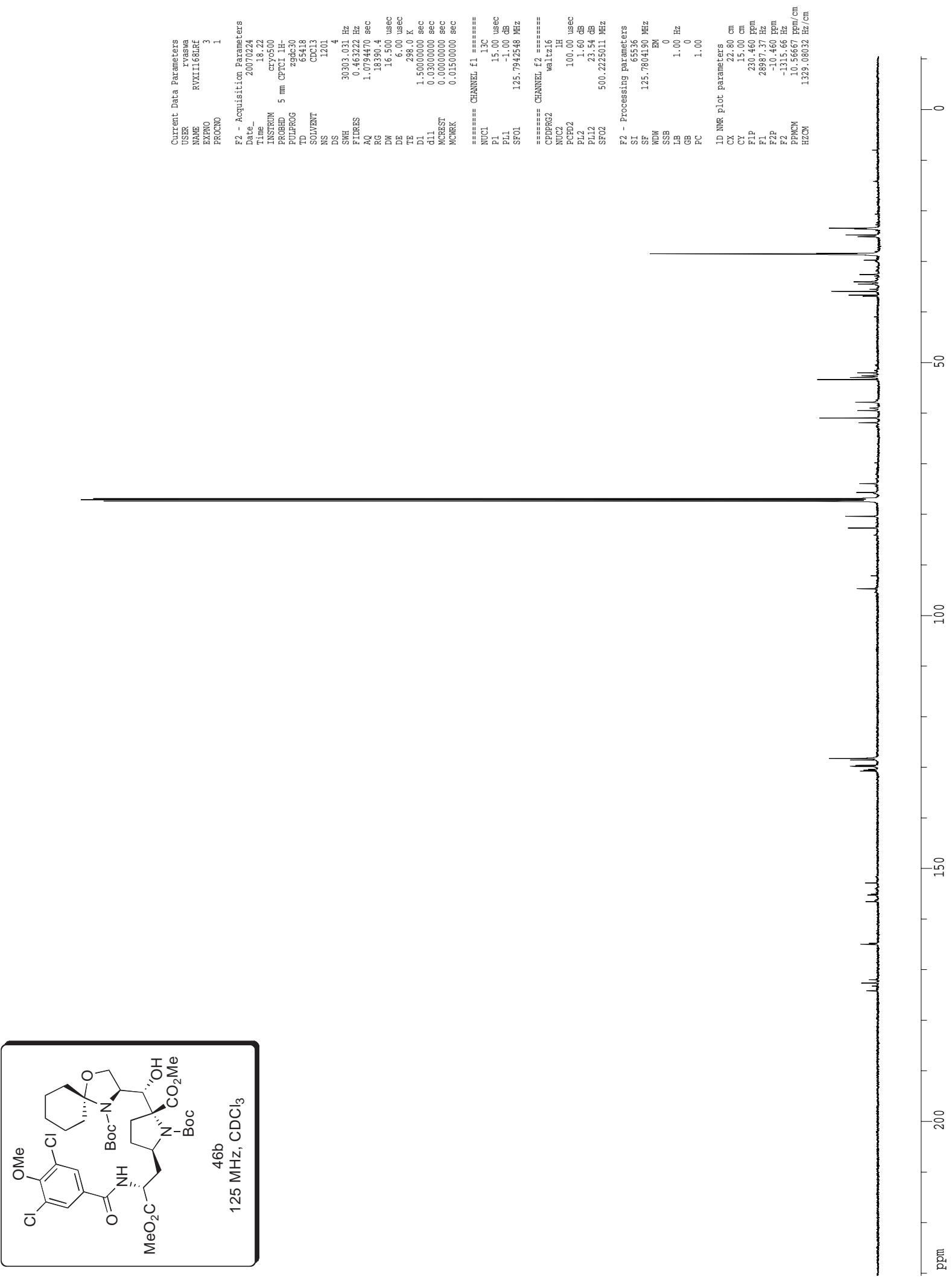

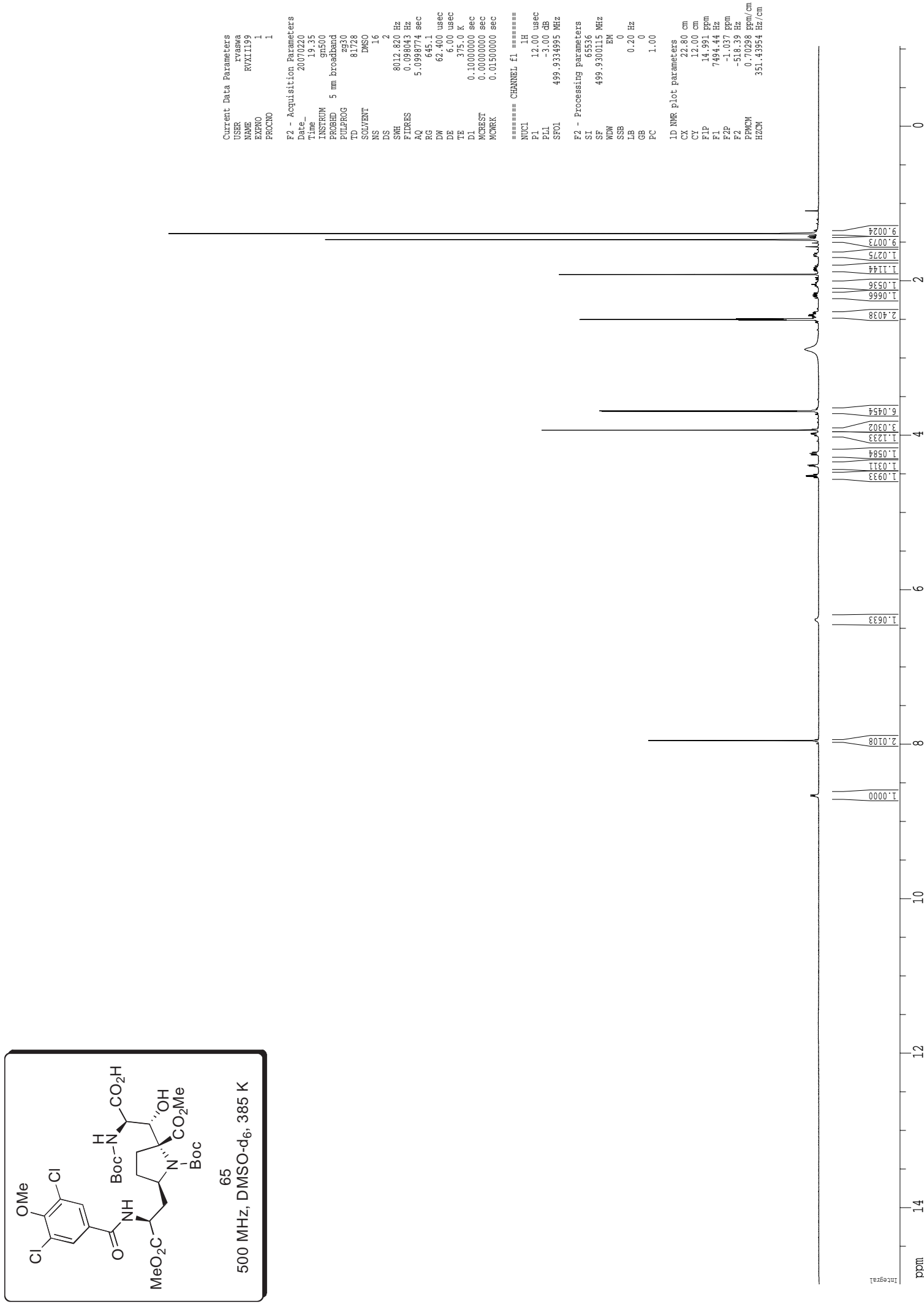

$-7$

-

$-\underset{\sim}{-}$

เехб6วบธ

-

-

$-$ 


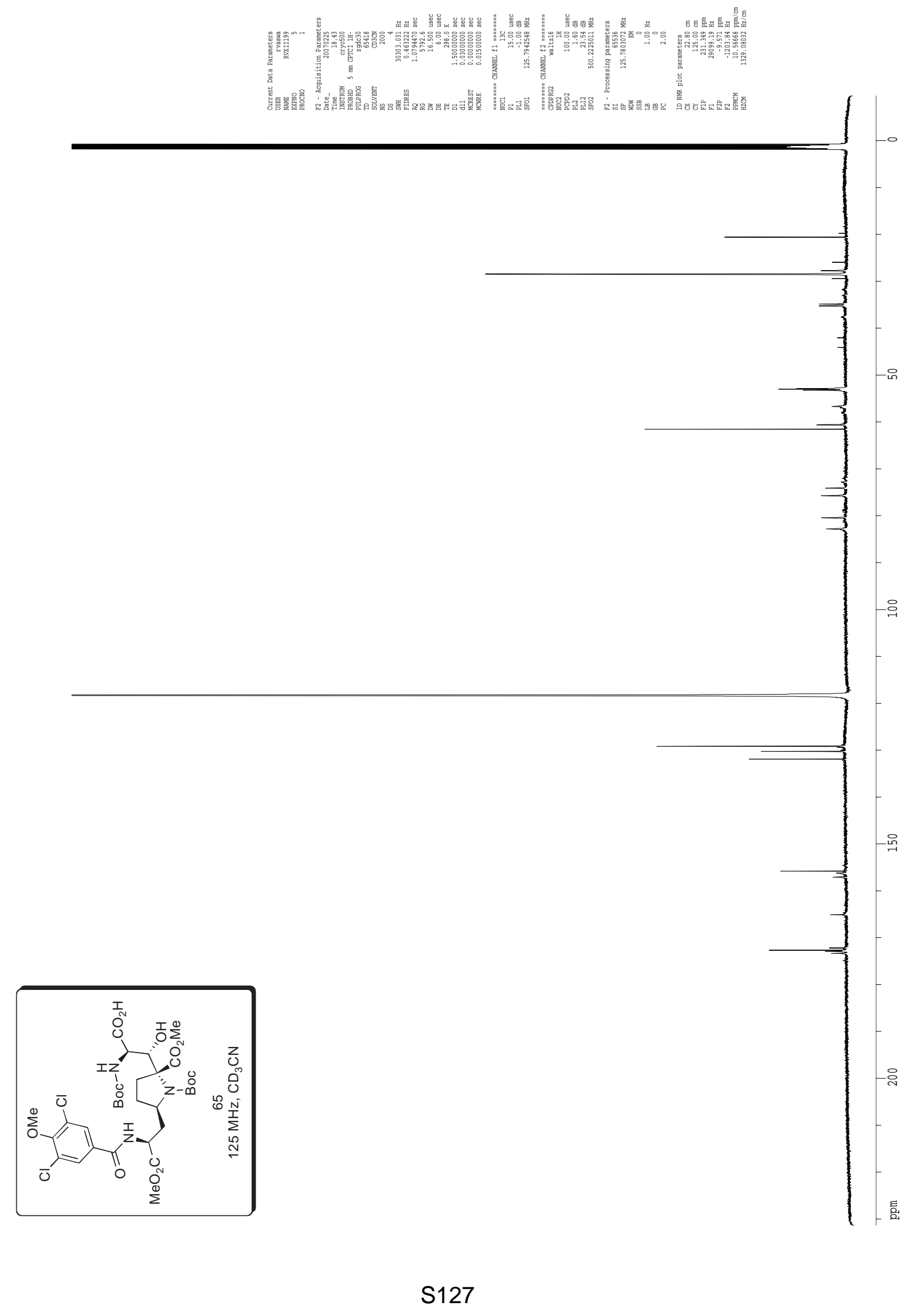



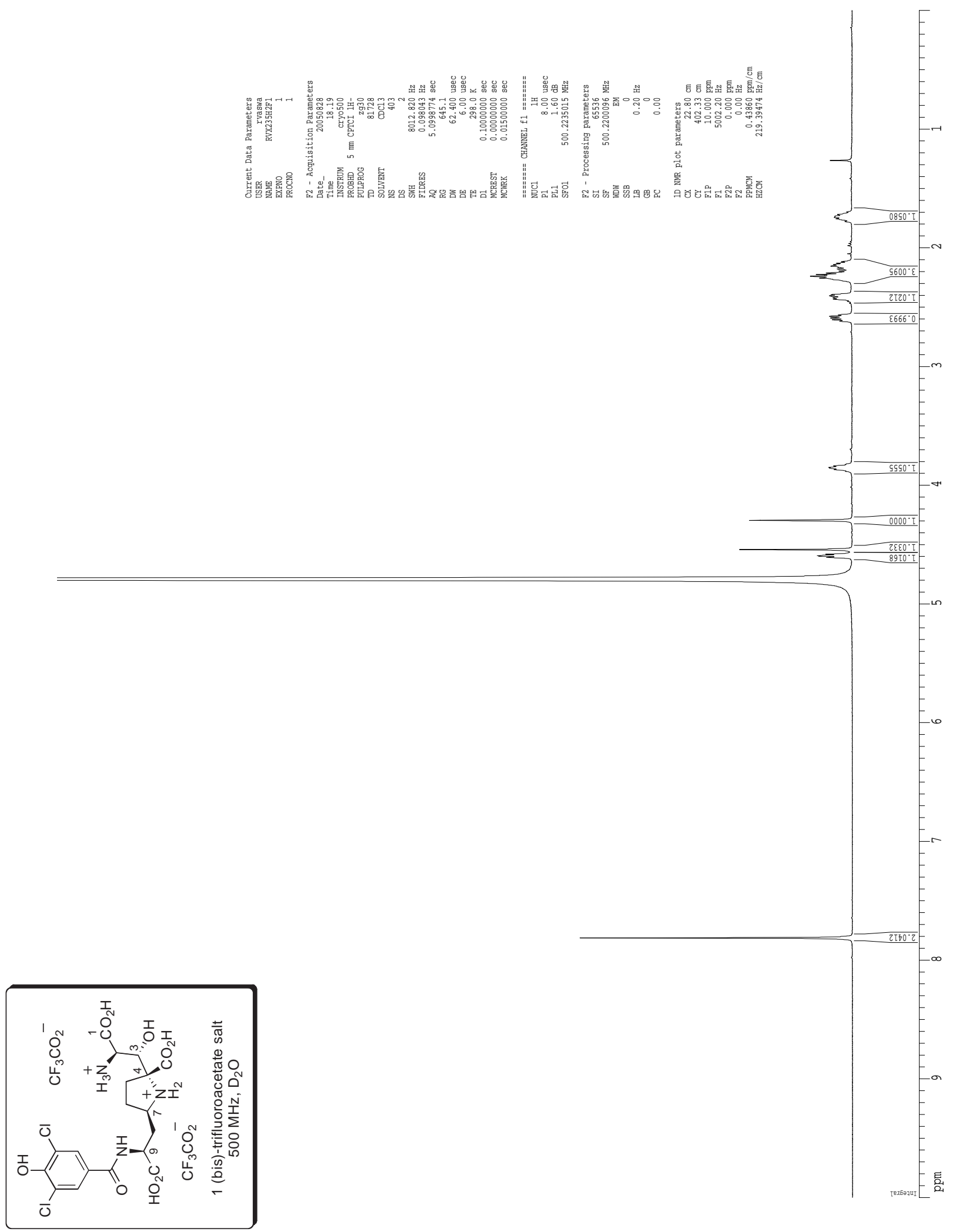

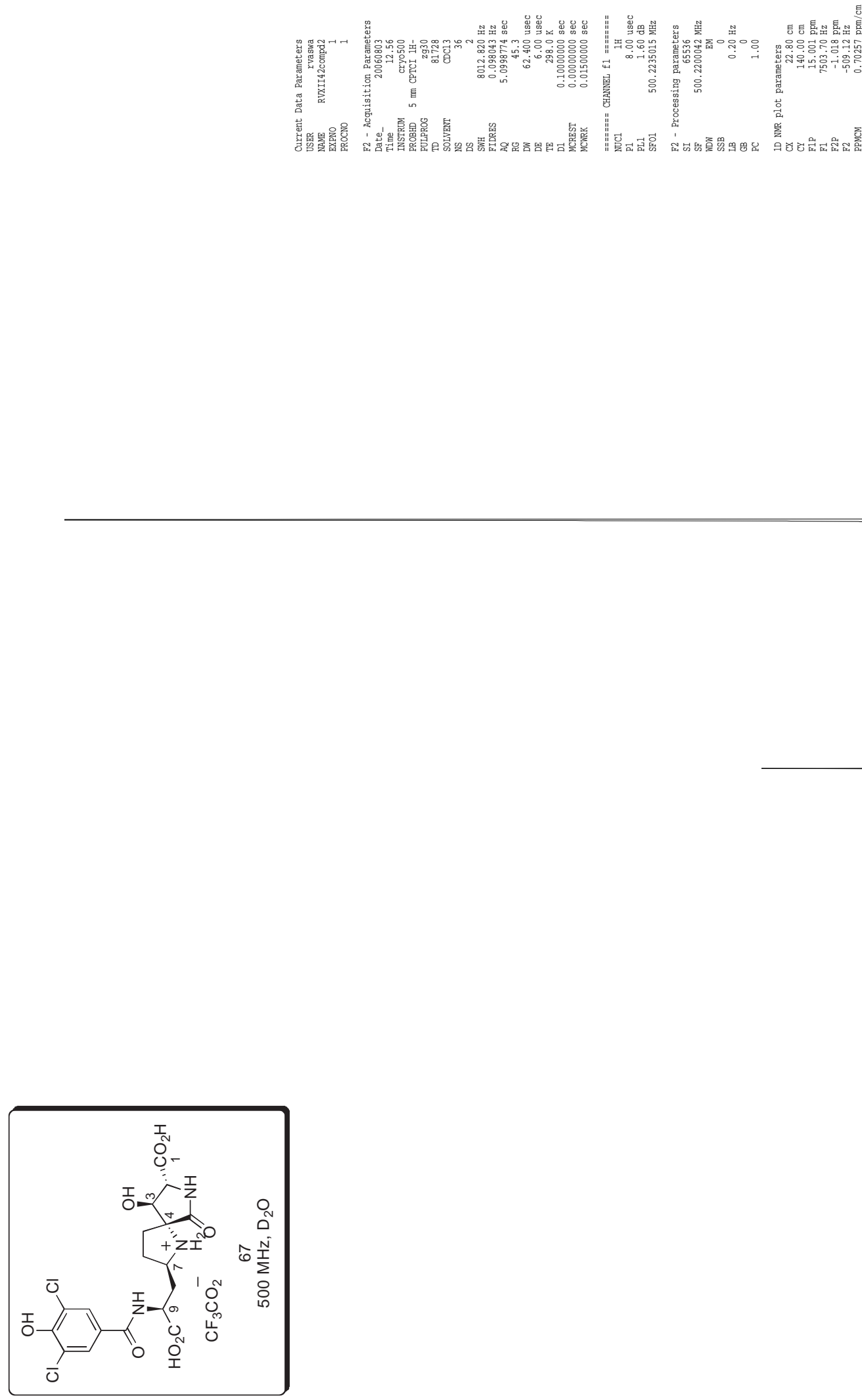


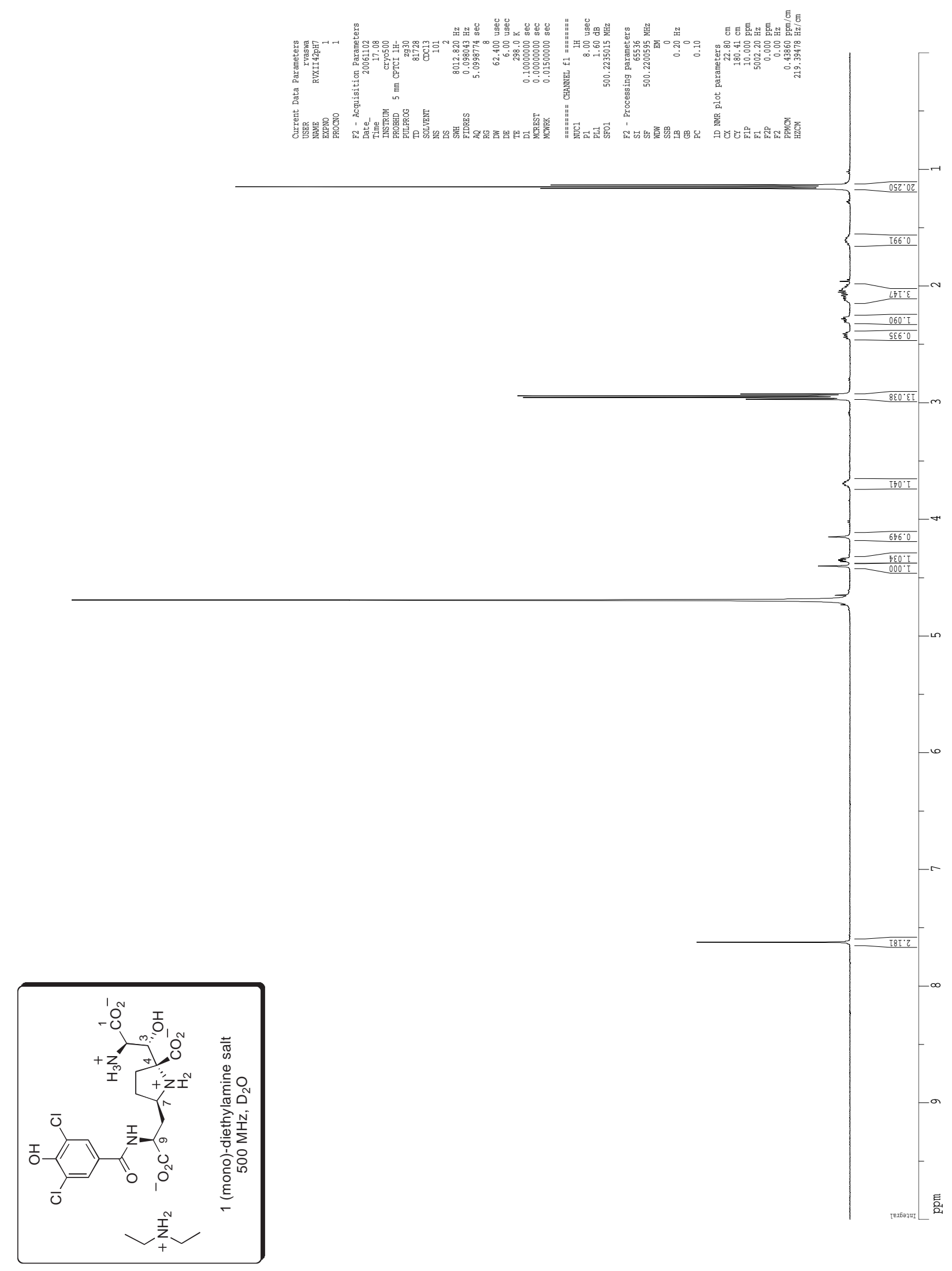




\section{X-ray crystallography data for Compounds}

\section{X-Ray Crystallography Report for 37 (CCDC 635171)}

\section{X-ray Data Collection and Structure Refinement for 37 (CCDC 635171)}

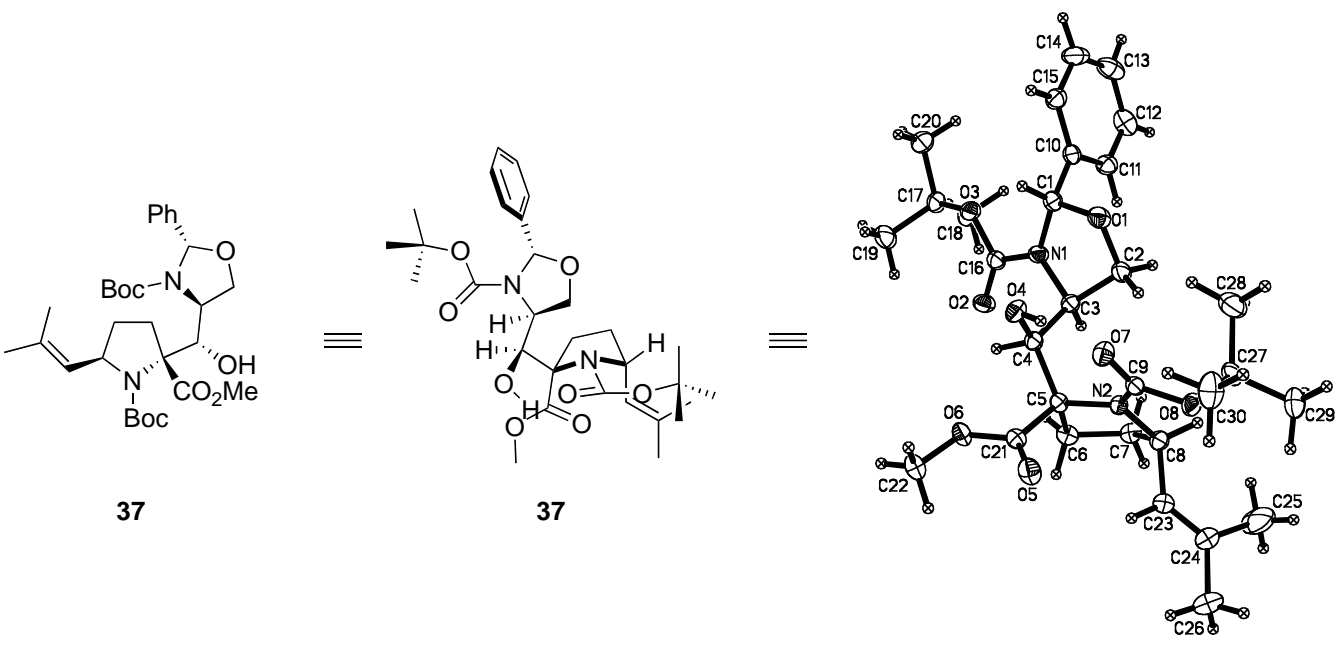

A colorless crystal of approximate dimensions $0.18 \times 0.32 \times 0.33 \mathrm{~mm}$ was mounted on a glass fiber and transferred to a Bruker CCD platform diffractometer. The SMART ${ }^{1}$ program package was used to determine the unit-cell parameters and for data collection $(25 \mathrm{sec} /$ frame scan time for a sphere of diffraction data). The raw frame data was processed using SAINT ${ }^{2}$ and $\mathrm{SADABS}^{3}$ to yield the reflection data file. Subsequent calculations were carried out using the SHELXTL ${ }^{4}$ program. The diffraction symmetry was $\mathrm{mmm}$ and the systematic absences were consistent with the orthorhombic space group $P 22_{1} 2_{1} 2_{1}$ that was later determined to be correct.

The structure was solved by direct methods and refined on $\mathrm{F}^{2}$ by full-matrix least-squares techniques. The analytical scattering factors ${ }^{5}$ for neutral atoms were used throughout the analysis. Hydrogen atoms were either located from a difference-Fourier map and refined $\left(\mathrm{x}, \mathrm{y}, \mathrm{Z}\right.$ and $\left.\mathrm{U}_{\text {iso }}\right)$ or were included using a riding model.

At convergence, $\mathrm{wR} 2=0.0783$ and $\mathrm{GOF}=1.064$ for 525 variables refined against 7082 data $(0.77 \AA)$. As a comparison for refinement on $\mathrm{F}, \mathrm{R} 1=0.0351$ for those 5841 data with I > 2.0(I). The absolute structure could not be assigned by inversion of the model or by refinement of the Flack $^{6}$ parameter.

Table 1. Crystal data and structure refinement for 37 .

Identification code

$\operatorname{arc9}$ (Rishi Vaswani) 
Empirical formula

Formula weight

Temperature

Wavelength

Crystal system

Space group

Unit cell dimensions

Volume

$\mathrm{Z}$

Density (calculated)

Absorption coefficient

$\mathrm{F}(000)$

Crystal color

Crystal size

Theta range for data collection

Index ranges

Reflections collected

Independent reflections

Completeness to theta $=27.47^{\circ}$

Absorption correction

Max. and min. transmission

Refinement method

Data / restraints / parameters

Goodness-of-fit on $\mathrm{F}^{2}$
$\mathrm{C}_{30} \mathrm{H}_{44} \mathrm{~N}_{2} \mathrm{O}_{8}$

560.67

163(2) K

$0.71073 \AA$

Orthorhombic

$P 2{ }_{1} 2_{1} 2_{1}$

$\mathrm{a}=6.5795(6) \AA \quad=90^{\circ}$.

$\mathrm{b}=17.0246(14) \AA \quad=90^{\circ}$.

$\mathrm{c}=27.565(2) \AA \quad=90^{\circ}$.

$3087.6(5) \AA^{3}$

4

$1.206 \mathrm{Mg} / \mathrm{m}^{3}$

$0.087 \mathrm{~mm}^{-1}$

1208

colorless

$0.33 \times 0.32 \times 0.18 \mathrm{~mm}^{3}$

1.48 to $27.47^{\circ}$

$-8 h 8,-22 k 22,-35 l 35$

33030

$7082[\mathrm{R}($ int $)=0.0426]$

$100.0 \%$

Semi-empirical from equivalents

0.9845 and 0.9719

Full-matrix least-squares on $\mathrm{F}^{2}$

7082 / 0 / 525

1.064

Final $R$ indices $[\mathrm{I}>2 \operatorname{sigma}(\mathrm{I})=5841$ data $]$

$\mathrm{R}$ indices (all data; $0.77 \AA$ )

$\mathrm{R} 1=0.0351, \mathrm{wR} 2=0.0708$

$\mathrm{R} 1=0.0518, \mathrm{wR} 2=0.0783$

Absolute structure parameter

$-0.5(7)$

Largest diff. peak and hole
0.202 and -0.143 e. $\AA^{-3}$

Table 2. Atomic coordinates ( $x 10^{4}$ ) and equivalent isotropic displacement parameters $\left(\AA^{2} \times 10^{3}\right)$ for 37 . U(eq) is defined as one third of the trace of the orthogonalized $U^{i j}$ tensor. 


\begin{tabular}{|c|c|c|c|c|}
\hline $\mathrm{O}(1)$ & $1619(2)$ & $2180(1)$ & $1287(1)$ & $28(1)$ \\
\hline $\mathrm{O}(2)$ & $-1205(2)$ & $313(1)$ & $2240(1)$ & $27(1)$ \\
\hline $\mathrm{O}(3)$ & $-963(2)$ & $1554(1)$ & 2551(1) & $26(1)$ \\
\hline $\mathrm{O}(4)$ & $4261(2)$ & $838(1)$ & $1628(1)$ & $26(1)$ \\
\hline $\mathrm{O}(5)$ & $6330(2)$ & $-955(1)$ & 1069(1) & $29(1)$ \\
\hline $\mathrm{O}(6)$ & $4725(2)$ & $-951(1)$ & $1785(1)$ & $24(1)$ \\
\hline $\mathrm{O}(7)$ & $6052(2)$ & $809(1)$ & $747(1)$ & $25(1)$ \\
\hline $\mathrm{O}(8)$ & $5023(2)$ & $429(1)$ & $-3(1)$ & $25(1)$ \\
\hline $\mathrm{N}(1)$ & $63(2)$ & $1330(1)$ & $1802(1)$ & $23(1)$ \\
\hline $\mathrm{N}(2)$ & $3397(2)$ & $-40(1)$ & 633(1) & $18(1)$ \\
\hline$C(1)$ & $709(3)$ & $2149(1)$ & $1758(1)$ & $22(1)$ \\
\hline$C(2)$ & $985(3)$ & $1508(1)$ & $1014(1)$ & $26(1)$ \\
\hline$C(3)$ & 691(3) & $855(1)$ & 1384(1) & 21(1) \\
\hline$C(4)$ & $2567(2)$ & $361(1)$ & $1512(1)$ & $20(1)$ \\
\hline$C(5)$ & $3069(2)$ & $-297(1)$ & $1142(1)$ & $18(1)$ \\
\hline$C(6)$ & $1269(2)$ & $-885(1)$ & $1088(1)$ & $22(1)$ \\
\hline$C(7)$ & $287(2)$ & $-685(1)$ & $602(1)$ & $22(1)$ \\
\hline$C(8)$ & $2090(2)$ & $-469(1)$ & $282(1)$ & $20(1)$ \\
\hline$C(9)$ & $4930(2)$ & $426(1)$ & $483(1)$ & $19(1)$ \\
\hline$C(10)$ & $-987(2)$ & $2747(1)$ & 1793(1) & $21(1)$ \\
\hline$C(11)$ & $-2858(3)$ & $2636(1)$ & $1569(1)$ & $26(1)$ \\
\hline$C(12)$ & $-4310(3)$ & $3222(1)$ & 1579(1) & $34(1)$ \\
\hline$C(13)$ & $-3928(3)$ & $3924(1)$ & $1813(1)$ & $37(1)$ \\
\hline$C(14)$ & $-2085(3)$ & $4037(1)$ & $2045(1)$ & $37(1)$ \\
\hline$C(15)$ & $-624(3)$ & $3451(1)$ & 2033(1) & $27(1)$ \\
\hline$C(16)$ & $-761(2)$ & $1002(1)$ & $2203(1)$ & $22(1)$ \\
\hline$C(17)$ & $-2333(3)$ & $1428(1)$ & $2967(1)$ & $27(1)$ \\
\hline $\mathrm{C}(18)$ & $-4468(3)$ & $1258(1)$ & $2783(1)$ & $39(1)$ \\
\hline$C(19)$ & $-1525(4)$ & 781(1) & $3290(1)$ & $37(1)$ \\
\hline$C(20)$ & $-2223(4)$ & $2222(1)$ & $3218(1)$ & $36(1)$ \\
\hline $\mathrm{C}(21)$ & 4931(2) & $-753(1)$ & $1320(1)$ & $20(1)$ \\
\hline$C(22)$ & $6407(3)$ & $-1381(1)$ & 1994(1) & $29(1)$ \\
\hline $\mathrm{C}(23)$ & $3165(3)$ & $-1168(1)$ & $65(1)$ & $23(1)$ \\
\hline$C(24)$ & $2713(3)$ & $-1501(1)$ & $-351(1)$ & $36(1)$ \\
\hline$C(25)$ & $1033(6)$ & $-1231(2)$ & $-674(1)$ & $96(1)$ \\
\hline
\end{tabular}




\begin{tabular}{lrrrr}
$\mathrm{C}(26)$ & $3848(5)$ & $-2209(1)$ & $-535(1)$ & $52(1)$ \\
$\mathrm{C}(27)$ & $6027(3)$ & $1062(1)$ & $-278(1)$ & $24(1)$ \\
$\mathrm{C}(28)$ & $5252(4)$ & $1852(1)$ & $-111(1)$ & $42(1)$ \\
$\mathrm{C}(29)$ & $5358(3)$ & $890(1)$ & $-794(1)$ & $35(1)$ \\
$\mathrm{C}(30)$ & $8312(3)$ & $989(2)$ & $-230(1)$ & $39(1)$ \\
\hline
\end{tabular}

Table 3. Bond lengths $[\AA]$ and angles $\left[{ }^{\circ}\right]$ for 37 .

\begin{tabular}{|c|c|}
\hline $\mathrm{O}(1)-\mathrm{C}(1)$ & $1.4298(19)$ \\
\hline $\mathrm{O}(1)-\mathrm{C}(2)$ & $1.432(2)$ \\
\hline $\mathrm{O}(2)-\mathrm{C}(16)$ & $1.2125(19)$ \\
\hline $\mathrm{O}(3)-\mathrm{C}(16)$ & $1.3493(19)$ \\
\hline $\mathrm{O}(3)-\mathrm{C}(17)$ & $1.4741(19)$ \\
\hline $\mathrm{O}(4)-\mathrm{C}(4)$ & $1.4153(19)$ \\
\hline $\mathrm{O}(5)-\mathrm{C}(21)$ & $1.2010(19)$ \\
\hline $\mathrm{O}(6)-\mathrm{C}(21)$ & $1.3345(18)$ \\
\hline $\mathrm{O}(6)-\mathrm{C}(22)$ & $1.446(2)$ \\
\hline $\mathrm{O}(7)-\mathrm{C}(9)$ & $1.2250(18)$ \\
\hline $\mathrm{O}(8)-\mathrm{C}(9)$ & $1.3411(17)$ \\
\hline $\mathrm{O}(8)-\mathrm{C}(27)$ & $1.4730(18)$ \\
\hline $\mathrm{N}(1)-\mathrm{C}(16)$ & $1.353(2)$ \\
\hline $\mathrm{N}(1)-\mathrm{C}(1)$ & $1.463(2)$ \\
\hline $\mathrm{N}(1)-\mathrm{C}(3)$ & $1.4659(19)$ \\
\hline $\mathrm{N}(2)-\mathrm{C}(9)$ & $1.349(2)$ \\
\hline $\mathrm{N}(2)-\mathrm{C}(5)$ & $1.4841(19)$ \\
\hline $\mathrm{N}(2)-\mathrm{C}(8)$ & $1.4877(19)$ \\
\hline $\mathrm{C}(1)-\mathrm{C}(10)$ & $1.514(2)$ \\
\hline$C(2)-C(3)$ & $1.521(2)$ \\
\hline$C(3)-C(4)$ & $1.535(2)$ \\
\hline$C(4)-C(5)$ & $1.551(2)$ \\
\hline$C(5)-C(21)$ & $1.531(2)$ \\
\hline$C(5)-C(6)$ & $1.558(2)$ \\
\hline$C(6)-C(7)$ & $1.526(2)$ \\
\hline$C(7)-C(8)$ & $1.524(2)$ \\
\hline$C(8)-C(23)$ & $1.508(2)$ \\
\hline
\end{tabular}




\begin{tabular}{|c|c|}
\hline$C(10)-C(15)$ & $1.390(2)$ \\
\hline$C(10)-C(11)$ & $1.390(2)$ \\
\hline$C(11)-C(12)$ & $1.383(3)$ \\
\hline$C(12)-C(13)$ & $1.381(3)$ \\
\hline$C(13)-C(14)$ & $1.384(3)$ \\
\hline$C(14)-C(15)$ & $1.385(3)$ \\
\hline$C(17)-C(19)$ & $1.514(3)$ \\
\hline $\mathrm{C}(17)-\mathrm{C}(18)$ & $1.521(3)$ \\
\hline$C(17)-C(20)$ & $1.522(3)$ \\
\hline $\mathrm{C}(23)-\mathrm{C}(24)$ & $1.312(2)$ \\
\hline$C(24)-C(25)$ & $1.492(3)$ \\
\hline$C(24)-C(26)$ & $1.507(3)$ \\
\hline $\mathrm{C}(27)-\mathrm{C}(28)$ & $1.511(3)$ \\
\hline $\mathrm{C}(27)-\mathrm{C}(30)$ & $1.514(3)$ \\
\hline $\mathrm{C}(27)-\mathrm{C}(29)$ & $1.520(2)$ \\
\hline $\mathrm{C}(1)-\mathrm{O}(1)-\mathrm{C}(2)$ & $108.94(12)$ \\
\hline$C(16)-O(3)-C(17)$ & $120.66(13)$ \\
\hline$C(21)-O(6)-C(22)$ & $115.64(13)$ \\
\hline $\mathrm{C}(9)-\mathrm{O}(8)-\mathrm{C}(27)$ & $122.42(12)$ \\
\hline$C(16)-N(1)-C(1)$ & $125.28(13)$ \\
\hline $\mathrm{C}(16)-\mathrm{N}(1)-\mathrm{C}(3)$ & $121.83(13)$ \\
\hline $\mathrm{C}(1)-\mathrm{N}(1)-\mathrm{C}(3)$ & $112.27(12)$ \\
\hline $\mathrm{C}(9)-\mathrm{N}(2)-\mathrm{C}(5)$ & $124.93(12)$ \\
\hline $\mathrm{C}(9)-\mathrm{N}(2)-\mathrm{C}(8)$ & $121.37(12)$ \\
\hline $\mathrm{C}(5)-\mathrm{N}(2)-\mathrm{C}(8)$ & $112.76(12)$ \\
\hline $\mathrm{O}(1)-\mathrm{C}(1)-\mathrm{N}(1)$ & $103.46(12)$ \\
\hline $\mathrm{O}(1)-\mathrm{C}(1)-\mathrm{C}(10)$ & $109.97(12)$ \\
\hline $\mathrm{N}(1)-\mathrm{C}(1)-\mathrm{C}(10)$ & $114.92(13)$ \\
\hline $\mathrm{O}(1)-\mathrm{C}(2)-\mathrm{C}(3)$ & $105.62(13)$ \\
\hline $\mathrm{N}(1)-\mathrm{C}(3)-\mathrm{C}(2)$ & $99.15(12)$ \\
\hline$N(1)-C(3)-C(4)$ & $110.40(13)$ \\
\hline $\mathrm{C}(2)-\mathrm{C}(3)-\mathrm{C}(4)$ & $116.89(14)$ \\
\hline $\mathrm{O}(4)-\mathrm{C}(4)-\mathrm{C}(3)$ & $111.78(13)$ \\
\hline $\mathrm{O}(4)-\mathrm{C}(4)-\mathrm{C}(5)$ & $113.26(13)$ \\
\hline$C(3)-C(4)-C(5)$ & $114.55(13)$ \\
\hline $\mathrm{N}(2)-\mathrm{C}(5)-\mathrm{C}(21)$ & $109.62(12)$ \\
\hline
\end{tabular}




\begin{tabular}{|c|c|}
\hline $\mathrm{N}(2)-\mathrm{C}(5)-\mathrm{C}(4)$ & $116.09(12)$ \\
\hline$C(21)-C(5)-C(4)$ & $109.02(12)$ \\
\hline $\mathrm{N}(2)-\mathrm{C}(5)-\mathrm{C}(6)$ & $102.12(12)$ \\
\hline$C(21)-C(5)-C(6)$ & $108.24(12)$ \\
\hline$C(4)-C(5)-C(6)$ & $111.37(13)$ \\
\hline$C(7)-C(6)-C(5)$ & $105.22(13)$ \\
\hline$C(8)-C(7)-C(6)$ & $103.46(13)$ \\
\hline $\mathrm{N}(2)-\mathrm{C}(8)-\mathrm{C}(23)$ & $112.04(13)$ \\
\hline $\mathrm{N}(2)-\mathrm{C}(8)-\mathrm{C}(7)$ & $100.99(12)$ \\
\hline$C(23)-C(8)-C(7)$ & $113.85(14)$ \\
\hline $\mathrm{O}(7)-\mathrm{C}(9)-\mathrm{O}(8)$ & $124.41(14)$ \\
\hline $\mathrm{O}(7)-\mathrm{C}(9)-\mathrm{N}(2)$ & $125.48(13)$ \\
\hline $\mathrm{O}(8)-\mathrm{C}(9)-\mathrm{N}(2)$ & $110.10(13)$ \\
\hline$C(15)-C(10)-C(11)$ & $118.74(16)$ \\
\hline$C(15)-C(10)-C(1)$ & $118.96(15)$ \\
\hline$C(11)-C(10)-C(1)$ & $122.19(14)$ \\
\hline$C(12)-C(11)-C(10)$ & $120.34(17)$ \\
\hline$C(13)-C(12)-C(11)$ & $120.52(19)$ \\
\hline$C(12)-C(13)-C(14)$ & $119.73(18)$ \\
\hline$C(13)-C(14)-C(15)$ & $119.77(17)$ \\
\hline$C(14)-C(15)-C(10)$ & $120.89(18)$ \\
\hline $\mathrm{O}(2)-\mathrm{C}(16)-\mathrm{O}(3)$ & $126.20(14)$ \\
\hline $\mathrm{O}(2)-\mathrm{C}(16)-\mathrm{N}(1)$ & $124.38(14)$ \\
\hline $\mathrm{O}(3)-\mathrm{C}(16)-\mathrm{N}(1)$ & $109.41(13)$ \\
\hline $\mathrm{O}(3)-\mathrm{C}(17)-\mathrm{C}(19)$ & $110.45(14)$ \\
\hline $\mathrm{O}(3)-\mathrm{C}(17)-\mathrm{C}(18)$ & $109.53(13)$ \\
\hline$C(19)-C(17)-C(18)$ & $112.49(17)$ \\
\hline $\mathrm{O}(3)-\mathrm{C}(17)-\mathrm{C}(20)$ & $101.26(14)$ \\
\hline$C(19)-C(17)-C(20)$ & $111.19(16)$ \\
\hline$C(18)-C(17)-C(20)$ & $111.35(16)$ \\
\hline $\mathrm{O}(5)-\mathrm{C}(21)-\mathrm{O}(6)$ & $124.02(14)$ \\
\hline $\mathrm{O}(5)-\mathrm{C}(21)-\mathrm{C}(5)$ & $125.01(14)$ \\
\hline $\mathrm{O}(6)-\mathrm{C}(21)-\mathrm{C}(5)$ & $110.78(13)$ \\
\hline$C(24)-C(23)-C(8)$ & $125.52(16)$ \\
\hline$C(23)-C(24)-C(25)$ & $123.79(18)$ \\
\hline$C(23)-C(24)-C(26)$ & $121.87(19)$ \\
\hline
\end{tabular}




$\begin{array}{ll}\mathrm{C}(25)-\mathrm{C}(24)-\mathrm{C}(26) & 114.33(18) \\ \mathrm{O}(8)-\mathrm{C}(27)-\mathrm{C}(28) & 110.09(14) \\ \mathrm{O}(8)-\mathrm{C}(27)-\mathrm{C}(30) & 109.90(14) \\ \mathrm{C}(28)-\mathrm{C}(27)-\mathrm{C}(30) & 112.49(18) \\ \mathrm{O}(8)-\mathrm{C}(27)-\mathrm{C}(29) & 102.15(14) \\ \mathrm{C}(28)-\mathrm{C}(27)-\mathrm{C}(29) & 111.08(16) \\ \mathrm{C}(30)-\mathrm{C}(27)-\mathrm{C}(29) & 110.66(16)\end{array}$

Table 4. Anisotropic displacement parameters $\left(\AA^{2} \times 10^{3}\right)$ for 37. The anisotropic displacement factor exponent takes the form: $-2 \pi^{2}\left[h^{2} a^{* 2} U^{11}+\ldots+2 h k\right.$ a* $\left.b^{*} U^{12}\right]$

\begin{tabular}{|c|c|c|c|c|c|c|}
\hline & $\mathrm{U}^{11}$ & $\mathrm{U}^{22}$ & $\mathrm{U}^{33}$ & $\mathrm{U}^{23}$ & $\mathrm{U}^{13}$ & $\mathrm{U}^{12}$ \\
\hline $\mathrm{O}(1)$ & $33(1)$ & $23(1)$ & $27(1)$ & $4(1)$ & $10(1)$ & $1(1)$ \\
\hline $\mathrm{O}(2)$ & $34(1)$ & $19(1)$ & $27(1)$ & $1(1)$ & $7(1)$ & 1(1) \\
\hline $\mathrm{O}(3)$ & $38(1)$ & $22(1)$ & $19(1)$ & $0(1)$ & $8(1)$ & $2(1)$ \\
\hline $\mathrm{O}(4)$ & $29(1)$ & $28(1)$ & $21(1)$ & $-4(1)$ & $-2(1)$ & $-3(1)$ \\
\hline $\mathrm{O}(5)$ & $21(1)$ & $39(1)$ & $28(1)$ & $6(1)$ & $4(1)$ & $8(1)$ \\
\hline $\mathrm{O}(6)$ & $23(1)$ & $27(1)$ & $23(1)$ & $7(1)$ & $2(1)$ & $5(1)$ \\
\hline $\mathrm{O}(7)$ & $26(1)$ & $28(1)$ & $22(1)$ & $1(1)$ & $-1(1)$ & $-7(1)$ \\
\hline $\mathrm{O}(8)$ & $36(1)$ & $22(1)$ & $18(1)$ & $2(1)$ & $2(1)$ & $-8(1)$ \\
\hline $\mathrm{N}(1)$ & $31(1)$ & $17(1)$ & $20(1)$ & $0(1)$ & $7(1)$ & $2(1)$ \\
\hline $\mathrm{N}(2)$ & $19(1)$ & $19(1)$ & $16(1)$ & $0(1)$ & $-1(1)$ & $-1(1)$ \\
\hline $\mathrm{C}(1)$ & $25(1)$ & $21(1)$ & $21(1)$ & $2(1)$ & $1(1)$ & $-2(1)$ \\
\hline$C(2)$ & $34(1)$ & $24(1)$ & $21(1)$ & $3(1)$ & $5(1)$ & $8(1)$ \\
\hline$C(3)$ & $25(1)$ & $20(1)$ & $18(1)$ & $-1(1)$ & $4(1)$ & $4(1)$ \\
\hline$C(4)$ & $22(1)$ & $20(1)$ & $17(1)$ & $1(1)$ & $2(1)$ & $2(1)$ \\
\hline$C(5)$ & $17(1)$ & $19(1)$ & $18(1)$ & $2(1)$ & $3(1)$ & $-1(1)$ \\
\hline$C(6)$ & $17(1)$ & $21(1)$ & $27(1)$ & $1(1)$ & $3(1)$ & $-2(1)$ \\
\hline$C(7)$ & $19(1)$ & $23(1)$ & $26(1)$ & $-2(1)$ & $0(1)$ & $-1(1)$ \\
\hline$C(8)$ & $19(1)$ & $20(1)$ & $21(1)$ & $-1(1)$ & $-4(1)$ & $-2(1)$ \\
\hline$C(9)$ & $22(1)$ & $18(1)$ & $19(1)$ & $2(1)$ & $1(1)$ & $3(1)$ \\
\hline$C(10)$ & $26(1)$ & $20(1)$ & $18(1)$ & $3(1)$ & $4(1)$ & $-2(1)$ \\
\hline $\mathrm{C}(11)$ & $28(1)$ & $23(1)$ & $28(1)$ & $0(1)$ & $1(1)$ & $-4(1)$ \\
\hline$C(12)$ & $24(1)$ & $38(1)$ & $40(1)$ & $10(1)$ & $1(1)$ & $1(1)$ \\
\hline
\end{tabular}




\begin{tabular}{lllllll}
$\mathrm{C}(13)$ & $38(1)$ & $27(1)$ & $47(1)$ & $6(1)$ & $16(1)$ & $8(1)$ \\
$\mathrm{C}(14)$ & $52(1)$ & $20(1)$ & $39(1)$ & $-5(1)$ & $12(1)$ & $-1(1)$ \\
$\mathrm{C}(15)$ & $30(1)$ & $26(1)$ & $24(1)$ & $-2(1)$ & $2(1)$ & $-3(1)$ \\
$\mathrm{C}(16)$ & $24(1)$ & $22(1)$ & $20(1)$ & $1(1)$ & $1(1)$ & $4(1)$ \\
$\mathrm{C}(17)$ & $34(1)$ & $29(1)$ & $17(1)$ & $1(1)$ & $6(1)$ & $6(1)$ \\
$\mathrm{C}(18)$ & $37(1)$ & $49(1)$ & $32(1)$ & $-5(1)$ & $7(1)$ & $3(1)$ \\
$\mathrm{C}(19)$ & $53(1)$ & $33(1)$ & $26(1)$ & $7(1)$ & $6(1)$ & $9(1)$ \\
$\mathrm{C}(20)$ & $50(1)$ & $34(1)$ & $24(1)$ & $-4(1)$ & $6(1)$ & $9(1)$ \\
$\mathrm{C}(21)$ & $18(1)$ & $19(1)$ & $22(1)$ & $2(1)$ & $1(1)$ & $-3(1)$ \\
$\mathrm{C}(22)$ & $26(1)$ & $31(1)$ & $29(1)$ & $8(1)$ & $-3(1)$ & $3(1)$ \\
$\mathrm{C}(23)$ & $23(1)$ & $21(1)$ & $25(1)$ & $-1(1)$ & $1(1)$ & $1(1)$ \\
$\mathrm{C}(24)$ & $51(1)$ & $30(1)$ & $28(1)$ & $-6(1)$ & $-3(1)$ & $6(1)$ \\
$\mathrm{C}(25)$ & $142(3)$ & $79(2)$ & $66(2)$ & $-44(2)$ & $-65(2)$ & $57(2)$ \\
$\mathrm{C}(26)$ & $76(2)$ & $39(1)$ & $41(1)$ & $-15(1)$ & $2(1)$ & $14(1)$ \\
$\mathrm{C}(27)$ & $27(1)$ & $22(1)$ & $22(1)$ & $7(1)$ & $4(1)$ & $-1(1)$ \\
$\mathrm{C}(28)$ & $58(2)$ & $27(1)$ & $41(1)$ & $8(1)$ & $8(1)$ & $6(1)$ \\
$\mathrm{C}(29)$ & $39(1)$ & $41(1)$ & $24(1)$ & $9(1)$ & $0(1)$ & $-3(1)$ \\
$\mathrm{C}(30)$ & $26(1)$ & $61(1)$ & $30(1)$ & $8(1)$ & $3(1)$ & $-4(1)$ \\
\hline
\end{tabular}

Table 5. Hydrogen coordinates ( x $\left.10^{4}\right)$ and isotropic displacement parameters $\left(\AA^{2} \times 10\right.$ 3 ) for 37.

\begin{tabular}{lcccc}
\hline & $\mathrm{x}$ & $\mathrm{y}$ & $\mathrm{z}$ & $\mathrm{U}(\mathrm{eq})$ \\
\hline $\mathrm{H}(25 \mathrm{~A})$ & 1608 & -998 & -969 & 115 \\
$\mathrm{H}(25 \mathrm{~B})$ & 210 & -838 & -504 & 115 \\
$\mathrm{H}(25 \mathrm{C})$ & 177 & -1680 & -762 & 115 \\
$\mathrm{H}(4)$ & $4930(40)$ & $871(14)$ & $1371(8)$ & $50(7)$ \\
$\mathrm{H}(1 \mathrm{~A})$ & $1760(30)$ & $2293(10)$ & $1989(6)$ & $20(4)$ \\
$\mathrm{H}(2 \mathrm{~A})$ & $2080(30)$ & $1390(11)$ & $782(6)$ & $26(5)$ \\
$\mathrm{H}(2 \mathrm{~B})$ & $-340(30)$ & $1626(9)$ & $834(6)$ & $21(4)$ \\
$\mathrm{H}(3 \mathrm{~A})$ & $-410(30)$ & $500(10)$ & $1300(6)$ & $21(4)$ \\
$\mathrm{H}(4 \mathrm{~A})$ & $2240(20)$ & $67(9)$ & $1827(6)$ & $15(4)$ \\
$\mathrm{H}(6 \mathrm{~A})$ & $380(30)$ & $-835(10)$ & $1364(6)$ & $21(4)$ \\
$\mathrm{H}(6 \mathrm{~B})$ & $1800(20)$ & $-1411(10)$ & $1069(5)$ & $12(4)$ \\
& & &
\end{tabular}




\begin{tabular}{|c|c|c|c|c|}
\hline $\mathrm{H}(7 \mathrm{~A})$ & $-650(30)$ & $-241(11)$ & $637(6)$ & $31(5)$ \\
\hline $\mathrm{H}(7 \mathrm{~B})$ & $-470(30)$ & $-1121(10)$ & $453(6)$ & $27(5)$ \\
\hline $\mathrm{H}(8 \mathrm{~A})$ & $1690(20)$ & $-110(9)$ & $25(6)$ & $15(4)$ \\
\hline $\mathrm{H}(11 \mathrm{~A})$ & $-3120(30)$ & $2150(12)$ & $1409(7)$ & $35(5)$ \\
\hline $\mathrm{H}(12 \mathrm{~A})$ & $-5650(40)$ & $3119(12)$ & $1408(7)$ & $48(6)$ \\
\hline $\mathrm{H}(13 \mathrm{~A})$ & $-4860(40)$ & $4333(13)$ & $1837(7)$ & $51(6)$ \\
\hline $\mathrm{H}(14 \mathrm{~A})$ & $-1790(30)$ & $4509(12)$ & $2221(7)$ & $40(5)$ \\
\hline $\mathrm{H}(15 \mathrm{~A})$ & $680(30)$ & $3530(10)$ & $2185(6)$ & $27(5)$ \\
\hline $\mathrm{H}(18 \mathrm{~A})$ & $-4520(40)$ & 778(14) & $2618(8)$ & $54(7)$ \\
\hline $\mathrm{H}(18 \mathrm{~B})$ & $-4900(40)$ & $1699(13)$ & $2551(8)$ & $55(6)$ \\
\hline $\mathrm{H}(18 \mathrm{C})$ & $-5460(40)$ & $1228(12)$ & $3067(8)$ & $50(6)$ \\
\hline $\mathrm{H}(19 \mathrm{~A})$ & $-100(30)$ & $881(11)$ & $3377(7)$ & $35(5)$ \\
\hline $\mathrm{H}(19 \mathrm{~B})$ & $-1600(30)$ & $285(12)$ & $3133(7)$ & $38(5)$ \\
\hline $\mathrm{H}(19 \mathrm{C})$ & $-2300(30)$ & $778(12)$ & $3586(8)$ & $41(6)$ \\
\hline $\mathrm{H}(20 \mathrm{~A})$ & $-780(40)$ & $2320(12)$ & $3343(7)$ & $43(6)$ \\
\hline $\mathrm{H}(20 \mathrm{~B})$ & $-3180(30)$ & $2229(12)$ & $3500(7)$ & $40(5)$ \\
\hline $\mathrm{H}(20 \mathrm{C})$ & $-2610(30)$ & $2636(12)$ & $2995(7)$ & $41(6)$ \\
\hline $\mathrm{H}(22 \mathrm{~A})$ & $6710(30)$ & $-1825(11)$ & $1785(6)$ & $23(5)$ \\
\hline $\mathrm{H}(22 \mathrm{~B})$ & $5980(30)$ & $-1536(11)$ & $2307(7)$ & $31(5)$ \\
\hline $\mathrm{H}(22 \mathrm{C})$ & $7610(30)$ & $-1011(12)$ & $2008(7)$ & $43(6)$ \\
\hline $\mathrm{H}(23 \mathrm{~A})$ & $4210(30)$ & $-1381(11)$ & $252(6)$ & $30(5)$ \\
\hline $\mathrm{H}(26 \mathrm{~A})$ & $2930(40)$ & $-2647(17)$ & $-611(10)$ & $78(9)$ \\
\hline $\mathrm{H}(26 \mathrm{~B})$ & $4880(40)$ & $-2393(13)$ & $-295(8)$ & $55(7)$ \\
\hline $\mathrm{H}(26 \mathrm{C})$ & $4480(50)$ & $-2093(16)$ & $-852(10)$ & $85(9)$ \\
\hline $\mathrm{H}(28 \mathrm{~A})$ & $5790(40)$ & $2246(13)$ & $-331(8)$ & $50(6)$ \\
\hline $\mathrm{H}(28 \mathrm{~B})$ & $3780(40)$ & $1822(12)$ & $-145(7)$ & $44(6)$ \\
\hline $\mathrm{H}(28 \mathrm{C})$ & $5610(40)$ & 2004(13) & $235(8)$ & $55(6)$ \\
\hline $\mathrm{H}(29 \mathrm{~A})$ & $5980(30)$ & $1273(11)$ & $-1011(7)$ & $37(5)$ \\
\hline $\mathrm{H}(29 \mathrm{~B})$ & $3860(40)$ & $919(13)$ & $-814(7)$ & $51(6)$ \\
\hline $\mathrm{H}(29 \mathrm{C})$ & $5780(30)$ & $344(13)$ & $-870(7)$ & $42(6)$ \\
\hline $\mathrm{H}(30 \mathrm{~A})$ & $8990(40)$ & $1359(13)$ & $-450(8)$ & $56(7)$ \\
\hline $\mathrm{H}(30 \mathrm{~B})$ & $8750(40)$ & $420(15)$ & $-335(8)$ & $64(7)$ \\
\hline $\mathrm{H}(30 \mathrm{C})$ & $8770(30)$ & $1076(12)$ & $106(8)$ & $46(6)$ \\
\hline
\end{tabular}

Table 6. Torsion angles $\left[{ }^{\circ}\right]$ for 37. 


\begin{tabular}{|c|c|}
\hline $\mathrm{C}(2)-\mathrm{O}(1)-\mathrm{C}(1)-\mathrm{N}(1)$ & $17.17(16)$ \\
\hline $\mathrm{C}(2)-\mathrm{O}(1)-\mathrm{C}(1)-\mathrm{C}(10)$ & $-106.06(15)$ \\
\hline $\mathrm{C}(16)-\mathrm{N}(1)-\mathrm{C}(1)-\mathrm{O}(1)$ & $175.19(15)$ \\
\hline $\mathrm{C}(3)-\mathrm{N}(1)-\mathrm{C}(1)-\mathrm{O}(1)$ & $4.13(17)$ \\
\hline $\mathrm{C}(16)-\mathrm{N}(1)-\mathrm{C}(1)-\mathrm{C}(10)$ & $-64.9(2)$ \\
\hline $\mathrm{C}(3)-\mathrm{N}(1)-\mathrm{C}(1)-\mathrm{C}(10)$ & $124.02(14)$ \\
\hline $\mathrm{C}(1)-\mathrm{O}(1)-\mathrm{C}(2)-\mathrm{C}(3)$ & $-31.51(17)$ \\
\hline $\mathrm{C}(16)-\mathrm{N}(1)-\mathrm{C}(3)-\mathrm{C}(2)$ & $166.98(15)$ \\
\hline $\mathrm{C}(1)-\mathrm{N}(1)-\mathrm{C}(3)-\mathrm{C}(2)$ & $-21.61(17)$ \\
\hline$C(16)-N(1)-C(3)-C(4)$ & $-69.75(19)$ \\
\hline $\mathrm{C}(1)-\mathrm{N}(1)-\mathrm{C}(3)-\mathrm{C}(4)$ & $101.66(15)$ \\
\hline $\mathrm{O}(1)-\mathrm{C}(2)-\mathrm{C}(3)-\mathrm{N}(1)$ & $31.10(16)$ \\
\hline $\mathrm{O}(1)-\mathrm{C}(2)-\mathrm{C}(3)-\mathrm{C}(4)$ & $-87.42(17)$ \\
\hline $\mathrm{N}(1)-\mathrm{C}(3)-\mathrm{C}(4)-\mathrm{O}(4)$ & $-62.57(16)$ \\
\hline $\mathrm{C}(2)-\mathrm{C}(3)-\mathrm{C}(4)-\mathrm{O}(4)$ & $49.69(18)$ \\
\hline$N(1)-C(3)-C(4)-C(5)$ & $166.88(13)$ \\
\hline $\mathrm{C}(2)-\mathrm{C}(3)-\mathrm{C}(4)-\mathrm{C}(5)$ & $-80.86(18)$ \\
\hline $\mathrm{C}(9)-\mathrm{N}(2)-\mathrm{C}(5)-\mathrm{C}(21)$ & $-59.31(18)$ \\
\hline $\mathrm{C}(8)-\mathrm{N}(2)-\mathrm{C}(5)-\mathrm{C}(21)$ & $109.65(14)$ \\
\hline $\mathrm{C}(9)-\mathrm{N}(2)-\mathrm{C}(5)-\mathrm{C}(4)$ & 64.72(19) \\
\hline $\mathrm{C}(8)-\mathrm{N}(2)-\mathrm{C}(5)-\mathrm{C}(4)$ & $-126.32(14)$ \\
\hline$C(9)-N(2)-C(5)-C(6)$ & $-173.93(14)$ \\
\hline $\mathrm{C}(8)-\mathrm{N}(2)-\mathrm{C}(5)-\mathrm{C}(6)$ & $-4.97(15)$ \\
\hline $\mathrm{O}(4)-\mathrm{C}(4)-\mathrm{C}(5)-\mathrm{N}(2)$ & $-72.82(16)$ \\
\hline $\mathrm{C}(3)-\mathrm{C}(4)-\mathrm{C}(5)-\mathrm{N}(2)$ & $57.01(18)$ \\
\hline $\mathrm{O}(4)-\mathrm{C}(4)-\mathrm{C}(5)-\mathrm{C}(21)$ & 51.54(16) \\
\hline$C(3)-C(4)-C(5)-C(21)$ & $-178.64(12)$ \\
\hline $\mathrm{O}(4)-\mathrm{C}(4)-\mathrm{C}(5)-\mathrm{C}(6)$ & $170.90(12)$ \\
\hline$C(3)-C(4)-C(5)-C(6)$ & $-59.27(17)$ \\
\hline$N(2)-C(5)-C(6)-C(7)$ & $-19.62(15)$ \\
\hline$C(21)-C(5)-C(6)-C(7)$ & $-135.25(13)$ \\
\hline$C(4)-C(5)-C(6)-C(7)$ & 104.93(14) \\
\hline$C(5)-C(6)-C(7)-C(8)$ & $36.63(16)$ \\
\hline $\mathrm{C}(9)-\mathrm{N}(2)-\mathrm{C}(8)-\mathrm{C}(23)$ & $75.06(18)$ \\
\hline $\mathrm{C}(5)-\mathrm{N}(2)-\mathrm{C}(8)-\mathrm{C}(23)$ & $-94.35(15)$ \\
\hline
\end{tabular}




\begin{tabular}{|c|c|}
\hline $\mathrm{C}(9)-\mathrm{N}(2)-\mathrm{C}(8)-\mathrm{C}(7)$ & $-163.41(13)$ \\
\hline $\mathrm{C}(5)-\mathrm{N}(2)-\mathrm{C}(8)-\mathrm{C}(7)$ & $27.19(15)$ \\
\hline $\mathrm{C}(6)-\mathrm{C}(7)-\mathrm{C}(8)-\mathrm{N}(2)$ & $-38.01(15)$ \\
\hline$C(6)-C(7)-C(8)-C(23)$ & $82.24(16)$ \\
\hline $\mathrm{C}(27)-\mathrm{O}(8)-\mathrm{C}(9)-\mathrm{O}(7)$ & $-19.5(2)$ \\
\hline $\mathrm{C}(27)-\mathrm{O}(8)-\mathrm{C}(9)-\mathrm{N}(2)$ & $158.86(13)$ \\
\hline $\mathrm{C}(5)-\mathrm{N}(2)-\mathrm{C}(9)-\mathrm{O}(7)$ & $-13.2(2)$ \\
\hline $\mathrm{C}(8)-\mathrm{N}(2)-\mathrm{C}(9)-\mathrm{O}(7)$ & $178.71(15)$ \\
\hline $\mathrm{C}(5)-\mathrm{N}(2)-\mathrm{C}(9)-\mathrm{O}(8)$ & $168.47(13)$ \\
\hline $\mathrm{C}(8)-\mathrm{N}(2)-\mathrm{C}(9)-\mathrm{O}(8)$ & $0.41(19)$ \\
\hline $\mathrm{O}(1)-\mathrm{C}(1)-\mathrm{C}(10)-\mathrm{C}(15)$ & $-101.30(16)$ \\
\hline $\mathrm{N}(1)-\mathrm{C}(1)-\mathrm{C}(10)-\mathrm{C}(15)$ & $142.48(15)$ \\
\hline $\mathrm{O}(1)-\mathrm{C}(1)-\mathrm{C}(10)-\mathrm{C}(11)$ & $74.76(19)$ \\
\hline $\mathrm{N}(1)-\mathrm{C}(1)-\mathrm{C}(10)-\mathrm{C}(11)$ & $-41.5(2)$ \\
\hline$C(15)-C(10)-C(11)-C(12)$ & $1.1(2)$ \\
\hline$C(1)-C(10)-C(11)-C(12)$ & $-174.99(15)$ \\
\hline$C(10)-C(11)-C(12)-C(13)$ & $-0.4(3)$ \\
\hline$C(11)-C(12)-C(13)-C(14)$ & $-0.7(3)$ \\
\hline $\mathrm{C}(12)-\mathrm{C}(13)-\mathrm{C}(14)-\mathrm{C}(15)$ & $1.1(3)$ \\
\hline$C(13)-C(14)-C(15)-C(10)$ & $-0.4(3)$ \\
\hline$C(11)-C(10)-C(15)-C(14)$ & $-0.7(2)$ \\
\hline$C(1)-C(10)-C(15)-C(14)$ & $175.54(15)$ \\
\hline $\mathrm{C}(17)-\mathrm{O}(3)-\mathrm{C}(16)-\mathrm{O}(2)$ & $-19.2(2)$ \\
\hline $\mathrm{C}(17)-\mathrm{O}(3)-\mathrm{C}(16)-\mathrm{N}(1)$ & $162.08(14)$ \\
\hline $\mathrm{C}(1)-\mathrm{N}(1)-\mathrm{C}(16)-\mathrm{O}(2)$ & $-176.54(16)$ \\
\hline $\mathrm{C}(3)-\mathrm{N}(1)-\mathrm{C}(16)-\mathrm{O}(2)$ & $-6.3(3)$ \\
\hline $\mathrm{C}(1)-\mathrm{N}(1)-\mathrm{C}(16)-\mathrm{O}(3)$ & $2.2(2)$ \\
\hline $\mathrm{C}(3)-\mathrm{N}(1)-\mathrm{C}(16)-\mathrm{O}(3)$ & $172.48(14)$ \\
\hline $\mathrm{C}(16)-\mathrm{O}(3)-\mathrm{C}(17)-\mathrm{C}(19)$ & $68.0(2)$ \\
\hline $\mathrm{C}(16)-\mathrm{O}(3)-\mathrm{C}(17)-\mathrm{C}(18)$ & $-56.43(19)$ \\
\hline $\mathrm{C}(16)-\mathrm{O}(3)-\mathrm{C}(17)-\mathrm{C}(20)$ & $-174.11(15)$ \\
\hline $\mathrm{C}(22)-\mathrm{O}(6)-\mathrm{C}(21)-\mathrm{O}(5)$ & $5.2(2)$ \\
\hline $\mathrm{C}(22)-\mathrm{O}(6)-\mathrm{C}(21)-\mathrm{C}(5)$ & $-179.53(13)$ \\
\hline $\mathrm{N}(2)-\mathrm{C}(5)-\mathrm{C}(21)-\mathrm{O}(5)$ & $-8.4(2)$ \\
\hline $\mathrm{C}(4)-\mathrm{C}(5)-\mathrm{C}(21)-\mathrm{O}(5)$ & $-136.52(16)$ \\
\hline $\mathrm{C}(6)-\mathrm{C}(5)-\mathrm{C}(21)-\mathrm{O}(5)$ & $102.19(17)$ \\
\hline
\end{tabular}




\begin{tabular}{lc}
$\mathrm{N}(2)-\mathrm{C}(5)-\mathrm{C}(21)-\mathrm{O}(6)$ & $176.35(12)$ \\
$\mathrm{C}(4)-\mathrm{C}(5)-\mathrm{C}(21)-\mathrm{O}(6)$ & $48.28(16)$ \\
$\mathrm{C}(6)-\mathrm{C}(5)-\mathrm{C}(21)-\mathrm{O}(6)$ & $-73.02(16)$ \\
$\mathrm{N}(2)-\mathrm{C}(8)-\mathrm{C}(23)-\mathrm{C}(24)$ & $-156.92(17)$ \\
$\mathrm{C}(7)-\mathrm{C}(8)-\mathrm{C}(23)-\mathrm{C}(24)$ & $89.3(2)$ \\
$\mathrm{C}(8)-\mathrm{C}(23)-\mathrm{C}(24)-\mathrm{C}(25)$ & $-0.2(3)$ \\
$\mathrm{C}(8)-\mathrm{C}(23)-\mathrm{C}(24)-\mathrm{C}(26)$ & $-178.78(19)$ \\
$\mathrm{C}(9)-\mathrm{O}(8)-\mathrm{C}(27)-\mathrm{C}(28)$ & $-50.8(2)$ \\
$\mathrm{C}(9)-\mathrm{O}(8)-\mathrm{C}(27)-\mathrm{C}(30)$ & $73.61(19)$ \\
$\mathrm{C}(9)-\mathrm{O}(8)-\mathrm{C}(27)-\mathrm{C}(29)$ & $-168.89(15)$ \\
\hline
\end{tabular}

X-Ray Crystallography Report for (Z)-39 (CCDC 635169)

X-ray Data Collection and Structure Refinement for (Z)-39 (CCDC 635169)

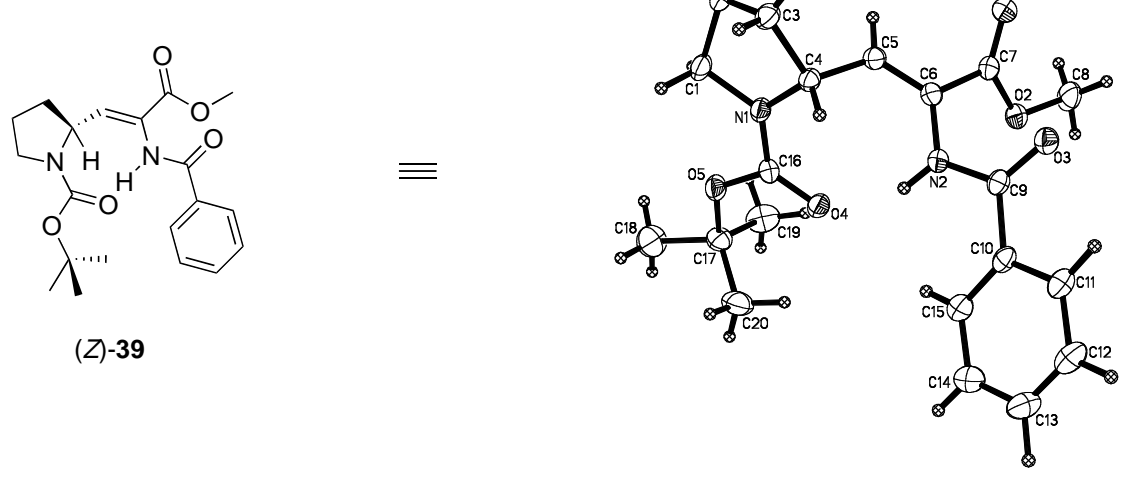

A colorless crystal of approximate dimensions $0.28 \times 0.35 \times 0.44 \mathrm{~mm}$ was mounted on a glass fiber and transferred to a Bruker CCD platform diffractometer. The SMART ${ }^{1}$ program package was used to determine the unit-cell parameters and for data collection $(25 \mathrm{sec} /$ frame scan time for a sphere of diffraction data). The raw frame data was processed using SAINT ${ }^{2}$ and $\mathrm{SADABS}^{3}$ to yield the reflection data file. Subsequent calculations were carried out using the SHELXTL ${ }^{4}$ program. The diffraction symmetry was $\mathrm{mmm}$ and the systematic absences were consistent with the orthorhombic space group $P 2_{1} 2_{1} 2_{1}$ that was later determined to be correct. 
The structure was solved by direct methods and refined on $\mathrm{F}^{2}$ by full-matrix least-squares techniques. The analytical scattering factors ${ }^{5}$ for neutral atoms were used throughout the analysis. Hydrogen atoms were located from a difference-Fourier map and refined (x,y,z and $\mathrm{U}_{\text {iso }}$ ). At convergence, $w R 2=0.0798$ and $\mathrm{Goof}=1.047$ for 348 variables refined against 4959 data. As a comparison for refinement on $\mathrm{F}, \mathrm{R} 1=0.0304$ for those 4497 data with I > 2.0(I). The absolute structure could not be assigned by inversion of the model or by refinement of the Flack parameter ${ }^{6}$.

Table 1. Crystal data and structure refinement for (Z)-39

Identification code

Empirical formula

Formula weight

Temperature

Wavelength

Crystal system

Space group

Unit cell dimensions

Volume

$\mathrm{Z}$

Density (calculated)

Absorption coefficient

$\mathrm{F}(000)$

Crystal color

Crystal size

Theta range for data collection

Index ranges

Reflections collected

Independent reflections

Completeness to theta $=28.31^{\circ}$

Absorption correction

Max. and min. transmission

Refinement method

Data / restraints / parameters

Goodness-of-fit on $\mathrm{F}^{2}$ $\operatorname{arc5}$ (Rishi Vaswani)

$\mathrm{C}_{20} \mathrm{H}_{26} \mathrm{~N}_{2} \mathrm{O}_{5}$

374.43

163(2) K

$0.71073 \AA$

Orthorhombic

$P 2{ }_{1} 2_{1} 2_{1}$

$\mathrm{a}=9.8901(10) \AA \quad \alpha=90^{\circ}$.

$\mathrm{b}=10.1942(10) \AA \quad \beta=90^{\circ}$.

$\mathrm{c}=19.957(2) \AA \quad \gamma=90^{\circ}$.

2012.1(3) $\AA^{3}$

4

$1.236 \mathrm{Mg} / \mathrm{m}^{3}$

$0.089 \mathrm{~mm}^{-1}$

800

colorless

$0.44 \times 0.35 \times 0.28 \mathrm{~mm}^{3}$

2.04 to $28.31^{\circ}$.

$-12 h 13,-13 k 13,-26 l 26$

22257

$4959[\mathrm{R}(\mathrm{int})=0.0254]$

$99.8 \%$

Semi-empirical from equivalents

0.9755 and 0.9619

Full-matrix least-squares on $\mathrm{F}^{2}$

4959 / 0 / 348

1.047 
Final $\mathrm{R}$ indices $[\mathrm{I}>2 \operatorname{sigma}(\mathrm{I})=4497$ data] $\mathrm{R} 1=0.0304, \mathrm{wR} 2=0.0757$

$\mathrm{R}$ indices (all data)

$\mathrm{R} 1=0.0363, \mathrm{wR} 2=0.0798$

Absolute structure parameter

$-0.1(6)$

Largest diff. peak and hole

0.225 and -0.173 e. $\AA^{-3}$

Table 2. Atomic coordinates ( $\times 10^{4}$ ) and equivalent isotropic displacement parameters $\left(\AA^{2} \times 10^{3}\right)$ for $(Z)-39$. U(eq) is defined as one third of the trace of the orthogonalized Uij tensor.

\begin{tabular}{|c|c|c|c|c|}
\hline & $\mathrm{x}$ & $\mathrm{y}$ & $\mathrm{z}$ & $\mathrm{U}(\mathrm{eq})$ \\
\hline $\mathrm{N}(1)$ & $5844(1)$ & 4399(1) & $1564(1)$ & $23(1)$ \\
\hline $\mathrm{N}(2)$ & $2270(1)$ & $4052(1)$ & $1047(1)$ & $23(1)$ \\
\hline $\mathrm{O}(1)$ & $2283(1)$ & 6936(1) & 49(1) & $35(1)$ \\
\hline $\mathrm{O}(2)$ & 1018(1) & $6428(1)$ & $951(1)$ & $27(1)$ \\
\hline $\mathrm{O}(3)$ & $687(1)$ & $3896(1)$ & $236(1)$ & $27(1)$ \\
\hline $\mathrm{O}(4)$ & $3933(1)$ & $3970(1)$ & $2160(1)$ & $27(1)$ \\
\hline $\mathrm{O}(5)$ & 5975(1) & $4298(1)$ & 2664(1) & $28(1)$ \\
\hline $\mathrm{C}(1)$ & $7297(1)$ & $4715(1)$ & $1532(1)$ & $28(1)$ \\
\hline $\mathrm{C}(2)$ & $7508(1)$ & $5027(1)$ & $796(1)$ & $27(1)$ \\
\hline $\mathrm{C}(3)$ & $6505(1)$ & $4116(1)$ & $445(1)$ & $26(1)$ \\
\hline $\mathrm{C}(4)$ & $5241(1)$ & $4155(1)$ & $897(1)$ & $21(1)$ \\
\hline$C(5)$ & $4264(1)$ & $5215(1)$ & 693(1) & 21(1) \\
\hline $\mathrm{C}(6)$ & $2922(1)$ & $5120(1)$ & $740(1)$ & $22(1)$ \\
\hline $\mathrm{C}(7)$ & $2048(1)$ & $6248(1)$ & $524(1)$ & $25(1)$ \\
\hline $\mathrm{C}(8)$ & $102(1)$ & $7475(1)$ & $774(1)$ & $37(1)$ \\
\hline $\mathrm{C}(9)$ & $1114(1)$ & $3542(1)$ & $783(1)$ & $22(1)$ \\
\hline$C(10)$ & $405(1)$ & $2522(1)$ & 1194(1) & $24(1)$ \\
\hline $\mathrm{C}(11)$ & $-582(1)$ & $1769(1)$ & $872(1)$ & $28(1)$ \\
\hline$C(12)$ & $-1278(1)$ & $805(2)$ & $1216(1)$ & $37(1)$ \\
\hline$C(13)$ & $-1022(2)$ & $606(2)$ & 1892(1) & $43(1)$ \\
\hline$C(14)$ & $-59(2)$ & $1360(2)$ & 2221(1) & $42(1)$ \\
\hline $\mathrm{C}(15)$ & 661(1) & 2311(1) & 1871(1) & $32(1)$ \\
\hline$C(16)$ & $5148(1)$ & $4209(1)$ & $2133(1)$ & $22(1)$ \\
\hline$C(17)$ & $5430(1)$ & $4470(1)$ & $3347(1)$ & $31(1)$ \\
\hline$C(18)$ & $6718(2)$ & $4426(3)$ & $3768(1)$ & $55(1)$ \\
\hline
\end{tabular}


$\mathrm{C}(19)$

4759(2)

$5797(2)$

$3381(1)$

42(1)

$\mathrm{C}(20)$

4499(2) 3349(2)

$3543(1)$

$42(1)$

Table 3. Bond lengths $[\AA]$ and angles $\left[{ }^{\circ}\right]$ for $(Z)-39$

\begin{tabular}{|c|c|}
\hline $\mathrm{N}(1)-\mathrm{C}(16)$ & $1.3420(15)$ \\
\hline $\mathrm{N}(1)-\mathrm{C}(1)$ & $1.4737(15)$ \\
\hline $\mathrm{N}(1)-\mathrm{C}(4)$ & $1.4806(14)$ \\
\hline $\mathrm{N}(2)-\mathrm{C}(9)$ & $1.3610(14)$ \\
\hline $\mathrm{N}(2)-\mathrm{C}(6)$ & $1.4064(15)$ \\
\hline $\mathrm{O}(1)-\mathrm{C}(7)$ & $1.2014(15)$ \\
\hline $\mathrm{O}(2)-\mathrm{C}(7)$ & $1.3409(15)$ \\
\hline $\mathrm{O}(2)-\mathrm{C}(8)$ & $1.4425(15)$ \\
\hline $\mathrm{O}(3)-\mathrm{C}(9)$ & $1.2265(14)$ \\
\hline $\mathrm{O}(4)-\mathrm{C}(16)$ & $1.2274(14)$ \\
\hline $\mathrm{O}(5)-\mathrm{C}(16)$ & $1.3418(13)$ \\
\hline $\mathrm{O}(5)-\mathrm{C}(17)$ & $1.4764(15)$ \\
\hline$C(1)-C(2)$ & $1.5183(18)$ \\
\hline$C(2)-C(3)$ & $1.5282(17)$ \\
\hline$C(3)-C(4)$ & $1.5414(16)$ \\
\hline$C(4)-C(5)$ & $1.5049(16)$ \\
\hline$C(5)-C(6)$ & $1.3342(17)$ \\
\hline$C(6)-C(7)$ & $1.5022(16)$ \\
\hline $\mathrm{C}(9)-\mathrm{C}(10)$ & $1.4987(16)$ \\
\hline$C(10)-C(15)$ & $1.3915(18)$ \\
\hline $\mathrm{C}(10)-\mathrm{C}(11)$ & 1.3987(17) \\
\hline $\mathrm{C}(11)-\mathrm{C}(12)$ & $1.3825(19)$ \\
\hline$C(12)-C(13)$ & $1.387(2)$ \\
\hline$C(13)-C(14)$ & $1.389(2)$ \\
\hline$C(14)-C(15)$ & $1.3897(19)$ \\
\hline $\mathrm{C}(17)-\mathrm{C}(19)$ & $1.508(2)$ \\
\hline$C(17)-C(20)$ & $1.519(2)$ \\
\hline $\mathrm{C}(17)-\mathrm{C}(18)$ & $1.526(2)$ \\
\hline$C(16)-N(1)-C(1)$ & $124.60(9)$ \\
\hline $\mathrm{C}(16)-\mathrm{N}(1)-\mathrm{C}(4)$ & $122.05(9)$ \\
\hline
\end{tabular}




$\begin{array}{ll}\mathrm{C}(1)-\mathrm{N}(1)-\mathrm{C}(4) & 113.00(9) \\ \mathrm{C}(9)-\mathrm{N}(2)-\mathrm{C}(6) & 120.84(10) \\ \mathrm{C}(7)-\mathrm{O}(2)-\mathrm{C}(8) & 115.02(10) \\ \mathrm{C}(16)-\mathrm{O}(5)-\mathrm{C}(17) & 121.01(9) \\ \mathrm{N}(1)-\mathrm{C}(1)-\mathrm{C}(2) & 102.83(9) \\ \mathrm{C}(1)-\mathrm{C}(2)-\mathrm{C}(3) & 103.06(10) \\ \mathrm{C}(2)-\mathrm{C}(3)-\mathrm{C}(4) & 104.11(9) \\ \mathrm{N}(1)-\mathrm{C}(4)-\mathrm{C}(5) & 112.38(9) \\ \mathrm{N}(1)-\mathrm{C}(4)-\mathrm{C}(3) & 101.71(9) \\ \mathrm{C}(5)-\mathrm{C}(4)-\mathrm{C}(3) & 112.42(9) \\ \mathrm{C}(6)-\mathrm{C}(5)-\mathrm{C}(4) & 124.55(11) \\ \mathrm{C}(5)-\mathrm{C}(6)-\mathrm{N}(2) & 122.94(10) \\ \mathrm{C}(5)-\mathrm{C}(6)-\mathrm{C}(7) & 119.78(11) \\ \mathrm{N}(2)-\mathrm{C}(6)-\mathrm{C}(7) & 116.98(10) \\ \mathrm{O}(1)-\mathrm{C}(7)-\mathrm{O}(2) & 124.59(11) \\ \mathrm{O}(1)-\mathrm{C}(7)-\mathrm{C}(6) & 124.22(11) \\ \mathrm{O}(2)-\mathrm{C}(7)-\mathrm{C}(6) & 111.10(10) \\ \mathrm{O}(3)-\mathrm{C}(9)-\mathrm{N}(2) & 121.42(10) \\ \mathrm{O}(3)-\mathrm{C}(9)-\mathrm{C}(10) & 122.07(10) \\ \mathrm{N}(2)-\mathrm{C}(9)-\mathrm{C}(10) & 116.51(10) \\ \mathrm{C}(15)-\mathrm{C}(10)-\mathrm{C}(11) & 119.30(11) \\ \mathrm{C}(15)-\mathrm{C}(10)-\mathrm{C}(9) & 123.60(11) \\ \mathrm{C}(11)-\mathrm{C}(10)-\mathrm{C}(9) & 117.09(10) \\ \mathrm{C}(12)-\mathrm{C}(11)-\mathrm{C}(10) & 120.53(12) \\ \mathrm{C}(11)-\mathrm{C}(12)-\mathrm{C}(13) & 119.82(13) \\ \mathrm{C}(12)-\mathrm{C}(13)-\mathrm{C}(14) & 120.21(13) \\ \mathrm{C}(13)-\mathrm{C}(14)-\mathrm{C}(15) & 120.00(14) \\ \mathrm{C}(14)-\mathrm{C}(15)-\mathrm{C}(10) & 120.13(13) \\ \mathrm{O}(4)-\mathrm{C}(16)-\mathrm{O}(5) & 125.14(10) \\ \mathrm{O}(4)-\mathrm{C}(16)-\mathrm{N}(1) & 124.56(10) \\ \mathrm{O}(5)-\mathrm{C}(16)-\mathrm{N}(1) & 110.29(9) \\ \mathrm{O}(5)-\mathrm{C}(17)-\mathrm{C}(19) & 108.00(11) \\ \mathrm{O}(5)-\mathrm{C}(17)-\mathrm{C}(20) & 111.67(11) \\ \mathrm{C}(19)-\mathrm{C}(17)-\mathrm{C}(20) & 113.34(13) \\ \mathrm{O}(5)-\mathrm{C}(17)-\mathrm{C}(18) & 101.50(12) \\ \mathrm{C}(19)-\mathrm{C}(17)-\mathrm{C}(18) & 111.65(15) \\ & \end{array}$


Table 4. Anisotropic displacement parameters $\left(\AA^{2} \times 10^{3}\right)$ for $(Z)-39$. The anisotropic displacement factor exponent takes the form: $-2 \pi^{2}\left[\mathrm{~h}^{2} \mathrm{a}^{* 2} \mathrm{U}^{11}+\ldots+2 \mathrm{~h} \mathrm{k} \mathrm{a}^{*} \mathrm{~b}^{*} \mathrm{U}^{12}\right]$

\begin{tabular}{|c|c|c|c|c|c|c|}
\hline & $\mathrm{U}^{11}$ & $\mathrm{U}^{22}$ & $\mathrm{U}^{33}$ & $\mathrm{U}^{23}$ & $\mathrm{U}^{13}$ & $\mathrm{U}^{12}$ \\
\hline $\mathrm{N}(1)$ & $17(1)$ & $29(1)$ & $22(1)$ & $0(1)$ & $-2(1)$ & $0(1)$ \\
\hline $\mathrm{N}(2)$ & $18(1)$ & $26(1)$ & $25(1)$ & $4(1)$ & $-3(1)$ & $-2(1)$ \\
\hline $\mathrm{O}(1)$ & $27(1)$ & $40(1)$ & $37(1)$ & $16(1)$ & $-2(1)$ & $-2(1)$ \\
\hline $\mathrm{O}(2)$ & $23(1)$ & $27(1)$ & $31(1)$ & $4(1)$ & $-2(1)$ & $4(1)$ \\
\hline $\mathrm{O}(3)$ & $24(1)$ & $33(1)$ & $25(1)$ & $0(1)$ & $-3(1)$ & $-2(1)$ \\
\hline $\mathrm{O}(4)$ & $19(1)$ & $39(1)$ & $23(1)$ & $2(1)$ & $-1(1)$ & $-2(1)$ \\
\hline $\mathrm{O}(5)$ & $21(1)$ & $40(1)$ & $21(1)$ & $0(1)$ & $-3(1)$ & $3(1)$ \\
\hline $\mathrm{C}(1)$ & $16(1)$ & $38(1)$ & $30(1)$ & $0(1)$ & $-2(1)$ & $-2(1)$ \\
\hline$C(2)$ & $17(1)$ & $33(1)$ & $31(1)$ & $2(1)$ & $1(1)$ & $-1(1)$ \\
\hline$C(3)$ & $21(1)$ & $33(1)$ & $25(1)$ & $-2(1)$ & $3(1)$ & $0(1)$ \\
\hline$C(4)$ & $18(1)$ & $25(1)$ & $20(1)$ & $-1(1)$ & $-1(1)$ & $-2(1)$ \\
\hline$C(5)$ & $21(1)$ & $24(1)$ & $20(1)$ & $0(1)$ & $-1(1)$ & $-2(1)$ \\
\hline$C(6)$ & $21(1)$ & $24(1)$ & $20(1)$ & $1(1)$ & $-2(1)$ & $-1(1)$ \\
\hline$C(7)$ & $20(1)$ & $28(1)$ & $26(1)$ & $3(1)$ & $-5(1)$ & $-3(1)$ \\
\hline $\mathrm{C}(8)$ & $24(1)$ & $31(1)$ & $55(1)$ & $10(1)$ & $-2(1)$ & $6(1)$ \\
\hline $\mathrm{C}(9)$ & $18(1)$ & $23(1)$ & $24(1)$ & $-3(1)$ & $1(1)$ & $2(1)$ \\
\hline$C(10)$ & $16(1)$ & $25(1)$ & $30(1)$ & $-2(1)$ & $3(1)$ & $1(1)$ \\
\hline$C(11)$ & $21(1)$ & $32(1)$ & $32(1)$ & $-5(1)$ & $3(1)$ & $-2(1)$ \\
\hline $\mathrm{C}(12)$ & $28(1)$ & $34(1)$ & $48(1)$ & $-4(1)$ & $3(1)$ & $-9(1)$ \\
\hline$C(13)$ & $35(1)$ & $40(1)$ & $53(1)$ & $12(1)$ & $5(1)$ & $-11(1)$ \\
\hline$C(14)$ & $38(1)$ & $50(1)$ & $37(1)$ & $14(1)$ & $-1(1)$ & $-9(1)$ \\
\hline$C(15)$ & $26(1)$ & $37(1)$ & $32(1)$ & $4(1)$ & $-2(1)$ & $-5(1)$ \\
\hline$C(16)$ & $20(1)$ & $22(1)$ & $22(1)$ & $0(1)$ & $-3(1)$ & $3(1)$ \\
\hline$C(17)$ & $32(1)$ & $41(1)$ & $19(1)$ & $2(1)$ & $-2(1)$ & $-4(1)$ \\
\hline$C(18)$ & $44(1)$ & $92(2)$ & $29(1)$ & $9(1)$ & $-14(1)$ & $-11(1)$ \\
\hline$C(19)$ & $50(1)$ & $36(1)$ & $39(1)$ & $-9(1)$ & $10(1)$ & $-4(1)$ \\
\hline$C(20)$ & $48(1)$ & $46(1)$ & $32(1)$ & $13(1)$ & $-1(1)$ & $-8(1)$ \\
\hline
\end{tabular}


Table 5. Hydrogen coordinates ( $\left.\mathrm{x} 10^{4}\right)$ and isotropic displacement parameters $\left(\AA^{2} \mathrm{x} 10\right.$ 3) for (Z)-39.

\begin{tabular}{|c|c|c|c|c|}
\hline & $\mathrm{x}$ & $\mathrm{y}$ & $\mathrm{z}$ & $\mathrm{U}(\mathrm{eq})$ \\
\hline $\mathrm{H}(1 \mathrm{~A})$ & $7499(17)$ & $5444(17)$ & $1829(8)$ & $35(4)$ \\
\hline $\mathrm{H}(1 \mathrm{~B})$ & $7798(16)$ & $3925(16)$ & $1685(7)$ & $30(4)$ \\
\hline $\mathrm{H}(2)$ & 2619(16) & $3770(16)$ & 1419(8) & $31(4)$ \\
\hline $\mathrm{H}(2 \mathrm{~A})$ & $7262(15)$ & $5913(15)$ & 704(7) & $24(3)$ \\
\hline $\mathrm{H}(2 \mathrm{~B})$ & $8379(15)$ & 4811(14) & $640(7)$ & $22(3)$ \\
\hline $\mathrm{H}(3 \mathrm{~A})$ & $6288(15)$ & 4393(14) & $-27(7)$ & $24(3)$ \\
\hline $\mathrm{H}(3 \mathrm{~B})$ & $6856(17)$ & $3245(17)$ & $425(8)$ & $35(4)$ \\
\hline $\mathrm{H}(4)$ & $4787(14)$ & $3281(15)$ & $905(7)$ & 22(3) \\
\hline $\mathrm{H}(5)$ & $4640(16)$ & $5989(17)$ & $522(8)$ & $29(4)$ \\
\hline $\mathrm{H}(8 \mathrm{~A})$ & $-356(19)$ & $7260(18)$ & $350(9)$ & $44(5)$ \\
\hline $\mathrm{H}(8 \mathrm{~B})$ & 533(17) & $8288(18)$ & 713(8) & $38(4)$ \\
\hline $\mathrm{H}(8 \mathrm{C})$ & $-440(20)$ & 7491(19) & 1162(10) & $54(5)$ \\
\hline $\mathrm{H}(11)$ & $-758(16)$ & 1983(15) & $405(8)$ & $32(4)$ \\
\hline $\mathrm{H}(12)$ & $-1928(18)$ & 272(17) & 992(9) & $42(5)$ \\
\hline $\mathrm{H}(13)$ & $-1510(20)$ & $-90(19)$ & 2161(10) & $54(5)$ \\
\hline $\mathrm{H}(14)$ & 132(19) & $1251(19)$ & 2706(9) & $51(5)$ \\
\hline $\mathrm{H}(15)$ & 1303(19) & 2864(18) & 2098(9) & $45(5)$ \\
\hline $\mathrm{H}(18 \mathrm{~A})$ & $7270(20)$ & $5160(20)$ & $3622(11)$ & $65(6)$ \\
\hline $\mathrm{H}(18 \mathrm{~B})$ & $6430(30)$ & $4570(20)$ & $4229(13)$ & $83(7)$ \\
\hline $\mathrm{H}(18 \mathrm{C})$ & $7120(30)$ & $3440(30)$ & $3722(14)$ & 107(9) \\
\hline $\mathrm{H}(19 \mathrm{~A})$ & $4496(18)$ & 5999(19) & $3859(9)$ & $46(5)$ \\
\hline $\mathrm{H}(19 \mathrm{~B})$ & $3990(20)$ & $5870(20)$ & $3085(10)$ & $55(5)$ \\
\hline $\mathrm{H}(19 \mathrm{C})$ & $5421(18)$ & $6479(19)$ & $3237(9)$ & $46(5)$ \\
\hline $\mathrm{H}(20 \mathrm{~A})$ & $4320(20)$ & $3379(19)$ & $4032(10)$ & $54(5)$ \\
\hline $\mathrm{H}(20 \mathrm{~B})$ & $3640(20)$ & $3418(18)$ & $3280(9)$ & $47(5)$ \\
\hline $\mathrm{H}(20 \mathrm{C})$ & $4940(20)$ & $2500(20)$ & $3447(10)$ & $55(5)$ \\
\hline
\end{tabular}

Table 6. Torsion angles $\left[{ }^{\circ}\right]$ for $(Z)-39$ 


\begin{tabular}{|c|c|}
\hline $\mathrm{C}(16)-\mathrm{N}(1)-\mathrm{C}(1)-\mathrm{C}(2)$ & $-171.68(11)$ \\
\hline $\mathrm{C}(4)-\mathrm{N}(1)-\mathrm{C}(1)-\mathrm{C}(2)$ & $14.98(13)$ \\
\hline$N(1)-C(1)-C(2)-C(3)$ & $-33.02(13)$ \\
\hline$C(1)-C(2)-C(3)-C(4)$ & $39.67(12)$ \\
\hline $\mathrm{C}(16)-\mathrm{N}(1)-\mathrm{C}(4)-\mathrm{C}(5)$ & $75.27(13)$ \\
\hline $\mathrm{C}(1)-\mathrm{N}(1)-\mathrm{C}(4)-\mathrm{C}(5)$ & $-111.20(11)$ \\
\hline $\mathrm{C}(16)-\mathrm{N}(1)-\mathrm{C}(4)-\mathrm{C}(3)$ & $-164.29(10)$ \\
\hline $\mathrm{C}(1)-\mathrm{N}(1)-\mathrm{C}(4)-\mathrm{C}(3)$ & $9.24(13)$ \\
\hline$C(2)-C(3)-C(4)-N(1)$ & $-29.73(12)$ \\
\hline$C(2)-C(3)-C(4)-C(5)$ & $90.68(11)$ \\
\hline $\mathrm{N}(1)-\mathrm{C}(4)-\mathrm{C}(5)-\mathrm{C}(6)$ & $-100.14(13)$ \\
\hline$C(3)-C(4)-C(5)-C(6)$ & $145.82(11)$ \\
\hline$C(4)-C(5)-C(6)-N(2)$ & $6.21(18)$ \\
\hline$C(4)-C(5)-C(6)-C(7)$ & $179.72(10)$ \\
\hline $\mathrm{C}(9)-\mathrm{N}(2)-\mathrm{C}(6)-\mathrm{C}(5)$ & $-140.64(12)$ \\
\hline $\mathrm{C}(9)-\mathrm{N}(2)-\mathrm{C}(6)-\mathrm{C}(7)$ & 45.68(15) \\
\hline $\mathrm{C}(8)-\mathrm{O}(2)-\mathrm{C}(7)-\mathrm{O}(1)$ & $4.85(18)$ \\
\hline $\mathrm{C}(8)-\mathrm{O}(2)-\mathrm{C}(7)-\mathrm{C}(6)$ & $-178.56(10)$ \\
\hline $\mathrm{C}(5)-\mathrm{C}(6)-\mathrm{C}(7)-\mathrm{O}(1)$ & $37.52(18)$ \\
\hline $\mathrm{N}(2)-\mathrm{C}(6)-\mathrm{C}(7)-\mathrm{O}(1)$ & $-148.59(12)$ \\
\hline $\mathrm{C}(5)-\mathrm{C}(6)-\mathrm{C}(7)-\mathrm{O}(2)$ & $-139.09(11)$ \\
\hline $\mathrm{N}(2)-\mathrm{C}(6)-\mathrm{C}(7)-\mathrm{O}(2)$ & $34.81(14)$ \\
\hline $\mathrm{C}(6)-\mathrm{N}(2)-\mathrm{C}(9)-\mathrm{O}(3)$ & $8.04(17)$ \\
\hline $\mathrm{C}(6)-\mathrm{N}(2)-\mathrm{C}(9)-\mathrm{C}(10)$ & $-172.46(10)$ \\
\hline $\mathrm{O}(3)-\mathrm{C}(9)-\mathrm{C}(10)-\mathrm{C}(15)$ & $-164.43(12)$ \\
\hline $\mathrm{N}(2)-\mathrm{C}(9)-\mathrm{C}(10)-\mathrm{C}(15)$ & $16.07(17)$ \\
\hline $\mathrm{O}(3)-\mathrm{C}(9)-\mathrm{C}(10)-\mathrm{C}(11)$ & $14.36(16)$ \\
\hline $\mathrm{N}(2)-\mathrm{C}(9)-\mathrm{C}(10)-\mathrm{C}(11)$ & $-165.14(10)$ \\
\hline $\mathrm{C}(15)-\mathrm{C}(10)-\mathrm{C}(11)-\mathrm{C}(12)$ & $-1.37(19)$ \\
\hline $\mathrm{C}(9)-\mathrm{C}(10)-\mathrm{C}(11)-\mathrm{C}(12)$ & $179.79(11)$ \\
\hline $\mathrm{C}(10)-\mathrm{C}(11)-\mathrm{C}(12)-\mathrm{C}(13)$ & $1.7(2)$ \\
\hline$C(11)-C(12)-C(13)-C(14)$ & $-0.8(2)$ \\
\hline $\mathrm{C}(12)-\mathrm{C}(13)-\mathrm{C}(14)-\mathrm{C}(15)$ & $-0.5(2)$ \\
\hline$C(13)-C(14)-C(15)-C(10)$ & $0.9(2)$ \\
\hline$C(11)-C(10)-C(15)-C(14)$ & $0.0(2)$ \\
\hline
\end{tabular}




$\begin{array}{lc}\mathrm{C}(9)-\mathrm{C}(10)-\mathrm{C}(15)-\mathrm{C}(14) & 178.79(13) \\ \mathrm{C}(17)-\mathrm{O}(5)-\mathrm{C}(16)-\mathrm{O}(4) & -16.96(18) \\ \mathrm{C}(17)-\mathrm{O}(5)-\mathrm{C}(16)-\mathrm{N}(1) & 164.02(10) \\ \mathrm{C}(1)-\mathrm{N}(1)-\mathrm{C}(16)-\mathrm{O}(4) & 178.53(12) \\ \mathrm{C}(4)-\mathrm{N}(1)-\mathrm{C}(16)-\mathrm{O}(4) & -8.71(18) \\ \mathrm{C}(1)-\mathrm{N}(1)-\mathrm{C}(16)-\mathrm{O}(5) & -2.44(16) \\ \mathrm{C}(4)-\mathrm{N}(1)-\mathrm{C}(16)-\mathrm{O}(5) & 170.32(10) \\ \mathrm{C}(16)-\mathrm{O}(5)-\mathrm{C}(17)-\mathrm{C}(19) & -66.00(14) \\ \mathrm{C}(16)-\mathrm{O}(5)-\mathrm{C}(17)-\mathrm{C}(20) & 59.27(15) \\ \mathrm{C}(16)-\mathrm{O}(5)-\mathrm{C}(17)-\mathrm{C}(18) & 176.49(13)\end{array}$

X-Ray Crystallography Report for 41b (CCDC 635170)

X-ray Data Collection and Structure Refinement for 41b (CCDC 635170)
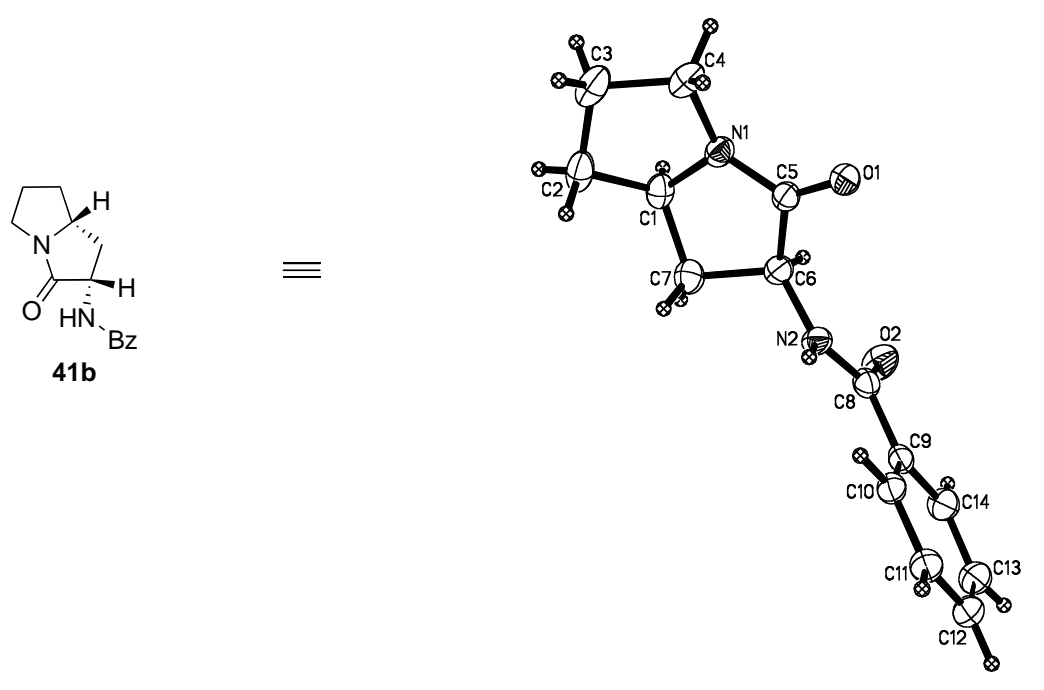

A colorless crystal of approximate dimensions $0.20 \times 0.26 \times 0.32 \mathrm{~mm}$ was mounted on a glass fiber and transferred to a Bruker CCD platform diffractometer. The SMART ${ }^{1}$ program package was used to determine the unit-cell parameters and for data collection $(25 \mathrm{sec} /$ frame scan time for a sphere of diffraction data). The raw frame data was processed using SAINT $^{2}$ and $\mathrm{SADABS}^{3}$ to yield the reflection data file. Subsequent 
calculations were carried out using the SHELXTL ${ }^{4}$ program. The diffraction symmetry was $\mathrm{mmm}$ and the systematic absences were consistent with the orthorhombic space group $P 2_{1} 22_{1} 2$ that was later determined to be correct.

The structure was solved by direct methods and refined on $\mathrm{F}^{2}$ by full-matrix least-squares techniques. The analytical scattering factors ${ }^{5}$ for neutral atoms were used throughout the analysis. Hydrogen atoms were located from a difference-Fourier map and refined (x,y,z and $\mathrm{U}_{\text {iso }}$ ). At convergence, $w R 2=0.0861$ and $\mathrm{GOF}=1.068$ for 228 variables refined against 2748 data $(0.78 \AA)$. As a comparison for refinement on $\mathrm{F}, \mathrm{R} 1=0.0318$ for those 2569 data with $\mathrm{I}>2.0(\mathrm{I})$. The absolute structure could not be assigned by inversion of the model or by refinement of the Flack ${ }^{6}$ parameter.

Table 1. Crystal data and structure refinement for $\mathbf{4 1 b}$

Identification code

Empirical formula

Formula weight

Temperature

Wavelength

Crystal system

Space group

Unit cell dimensions

Volume

Z

Density (calculated)

Absorption coefficient

$\mathrm{F}(000)$

Crystal color

Crystal size

Theta range for data collection

Index ranges

Reflections collected

Independent reflections

Completeness to theta $=27.10^{\circ}$

Absorption correction

Max. and min. transmission

Refinement method arc7 (Rishi Vaswani)

$\mathrm{C}_{14} \mathrm{H}_{16} \mathrm{~N}_{2} \mathrm{O}_{2}$

244.29

163(2) K

$0.71073 \AA$

Orthorhombic

$P 2{ }_{1} 22$

$$
\begin{array}{ll}
\mathrm{a}=9.5277(8) \AA & \alpha=90^{\circ} . \\
\mathrm{b}=10.5566(9) \AA & \beta=90^{\circ} . \\
\mathrm{c}=12.3874(10) \AA & \gamma=90^{\circ} .
\end{array}
$$

1245.93(18) $\AA^{3}$

4

$1.302 \mathrm{Mg} / \mathrm{m}^{3}$

$0.088 \mathrm{~mm}^{-1}$

520

colorless

$0.32 \times 0.26 \times 0.20 \mathrm{~mm}^{3}$

1.64 to $27.10^{\circ}$.

$-12 h 12,-13 k 13,-15 \quad l \quad 15$

14989

$2748[\mathrm{R}(\mathrm{int})=0.0257]$

$100.0 \%$

Semi-empirical from equivalents

0.9825 and 0.9723

Full-matrix least-squares on $\mathrm{F}^{2}$ 
Data / restraints / parameters

$2748 / 0 / 228$

Goodness-of-fit on $\mathrm{F}^{2}$

1.068

Final $\mathrm{R}$ indices $[\mathrm{I}>2 \operatorname{sigma}(\mathrm{I})=2569$ data $] \quad \mathrm{R} 1=0.0318, \mathrm{wR} 2=0.0821$

$\mathrm{R}$ indices (all data; $0.78 \AA$ )

$\mathrm{R} 1=0.0358, \mathrm{wR} 2=0.0861$

Absolute structure parameter

$0.2(11)$

Extinction coefficient

$0.002(2)$

Largest diff. peak and hole

0.758 and -0.135 e. $\AA^{-3}$

Table 2. Atomic coordinates ( $x 10^{4}$ ) and equivalent isotropic displacement parameters $\left(\AA^{2} \times 10^{3}\right)$ for $\mathbf{4 1 b}$. U(eq) is defined as one third of the trace of the orthogonalized $\mathrm{Uij}^{\mathrm{ij}}$ tensor.

\begin{tabular}{|c|c|c|c|c|}
\hline & $\mathrm{X}$ & $\mathrm{y}$ & $\mathrm{z}$ & $\mathrm{U}(\mathrm{eq})$ \\
\hline $\mathrm{O}(1)$ & $1820(1)$ & $4965(1)$ & $348(1)$ & $30(1)$ \\
\hline $\mathrm{O}(2)$ & $914(1)$ & $2110(1)$ & $2848(1)$ & $39(1)$ \\
\hline $\mathrm{N}(1)$ & 1549(1) & $3475(1)$ & $-981(1)$ & $26(1)$ \\
\hline $\mathrm{N}(2)$ & $-73(1)$ & $3343(1)$ & $1572(1)$ & $26(1)$ \\
\hline $\mathrm{C}(1)$ & $857(2)$ & 2251(1) & $-1172(1)$ & $28(1)$ \\
\hline$C(2)$ & $117(2)$ & $2477(2)$ & $-2251(1)$ & $36(1)$ \\
\hline$C(3)$ & $1068(2)$ & $3418(2)$ & $-2847(1)$ & $37(1)$ \\
\hline$C(4)$ & $1854(2)$ & $4175(2)$ & $-1972(1)$ & $34(1)$ \\
\hline$C(5)$ & $1445(1)$ & $3911(1)$ & $24(1)$ & $24(1)$ \\
\hline$C(6)$ & $781(1)$ & 2851(1) & $704(1)$ & $25(1)$ \\
\hline$C(7)$ & $-22(2)$ & $2076(1)$ & $-149(1)$ & $31(1)$ \\
\hline$C(8)$ & $56(2)$ & $2920(1)$ & $2597(1)$ & $26(1)$ \\
\hline$C(9)$ & $-928(1)$ & $3486(1)$ & $3415(1)$ & $25(1)$ \\
\hline$C(10)$ & $-1865(2)$ & $4464(1)$ & $3186(1)$ & $26(1)$ \\
\hline$C(11)$ & $-2763(2)$ & $4917(2)$ & $3978(1)$ & $29(1)$ \\
\hline$C(12)$ & $-2762(2)$ & $4379(2)$ & $5005(1)$ & $31(1)$ \\
\hline$C(13)$ & $-1835(2)$ & $3409(2)$ & $5236(1)$ & $35(1)$ \\
\hline$C(14)$ & $-912(2)$ & $2973(2)$ & $4456(1)$ & $32(1)$ \\
\hline
\end{tabular}

Table 3. Bond lengths $[\AA]$ and angles $\left[^{\circ}\right]$ for $\mathbf{4 1 b}$. 


\begin{tabular}{|c|c|}
\hline $\mathrm{O}(1)-\mathrm{C}(5)$ & $1.2350(17)$ \\
\hline $\mathrm{O}(2)-\mathrm{C}(8)$ & $1.2228(18)$ \\
\hline $\mathrm{N}(1)-\mathrm{C}(5)$ & $1.3307(17)$ \\
\hline $\mathrm{N}(1)-\mathrm{C}(4)$ & $1.4626(18)$ \\
\hline $\mathrm{N}(1)-\mathrm{C}(1)$ & $1.4690(18)$ \\
\hline $\mathrm{N}(2)-\mathrm{C}(8)$ & $1.3514(16)$ \\
\hline $\mathrm{N}(2)-\mathrm{C}(6)$ & $1.4453(17)$ \\
\hline$C(1)-C(2)$ & $1.529(2)$ \\
\hline$C(1)-C(7)$ & $1.530(2)$ \\
\hline$C(2)-C(3)$ & $1.534(3)$ \\
\hline$C(3)-C(4)$ & $1.540(2)$ \\
\hline$C(5)-C(6)$ & $1.5368(19)$ \\
\hline$C(6)-C(7)$ & $1.5400(19)$ \\
\hline$C(8)-C(9)$ & $1.5043(19)$ \\
\hline $\mathrm{C}(9)-\mathrm{C}(10)$ & $1.394(2)$ \\
\hline C(9)-C(14) & $1.3982(19)$ \\
\hline $\mathrm{C}(10)-\mathrm{C}(11)$ & $1.386(2)$ \\
\hline$C(11)-C(12)$ & $1.394(2)$ \\
\hline$C(12)-C(13)$ & $1.382(2)$ \\
\hline$C(13)-C(14)$ & $1.386(2)$ \\
\hline $\mathrm{C}(5)-\mathrm{N}(1)-\mathrm{C}(4)$ & $128.70(12)$ \\
\hline $\mathrm{C}(5)-\mathrm{N}(1)-\mathrm{C}(1)$ & $114.95(11)$ \\
\hline $\mathrm{C}(4)-\mathrm{N}(1)-\mathrm{C}(1)$ & $113.43(11)$ \\
\hline $\mathrm{C}(8)-\mathrm{N}(2)-\mathrm{C}(6)$ & $121.93(12)$ \\
\hline $\mathrm{N}(1)-\mathrm{C}(1)-\mathrm{C}(2)$ & $102.17(12)$ \\
\hline $\mathrm{N}(1)-\mathrm{C}(1)-\mathrm{C}(7)$ & $102.61(11)$ \\
\hline$C(2)-C(1)-C(7)$ & 119.31(13) \\
\hline $\mathrm{C}(1)-\mathrm{C}(2)-\mathrm{C}(3)$ & $104.44(13)$ \\
\hline $\mathrm{C}(2)-\mathrm{C}(3)-\mathrm{C}(4)$ & $106.51(12)$ \\
\hline $\mathrm{N}(1)-\mathrm{C}(4)-\mathrm{C}(3)$ & $103.44(13)$ \\
\hline $\mathrm{O}(1)-\mathrm{C}(5)-\mathrm{N}(1)$ & $126.43(13)$ \\
\hline $\mathrm{O}(1)-\mathrm{C}(5)-\mathrm{C}(6)$ & $126.65(12)$ \\
\hline $\mathrm{N}(1)-\mathrm{C}(5)-\mathrm{C}(6)$ & $106.92(11)$ \\
\hline $\mathrm{N}(2)-\mathrm{C}(6)-\mathrm{C}(5)$ & $112.17(11)$ \\
\hline $\mathrm{N}(2)-\mathrm{C}(6)-\mathrm{C}(7)$ & $114.95(11)$ \\
\hline$C(5)-C(6)-C(7)$ & $102.41(11)$ \\
\hline
\end{tabular}




$\begin{array}{ll}\mathrm{C}(1)-\mathrm{C}(7)-\mathrm{C}(6) & 103.41(12) \\ \mathrm{O}(2)-\mathrm{C}(8)-\mathrm{N}(2) & 122.06(13) \\ \mathrm{O}(2)-\mathrm{C}(8)-\mathrm{C}(9) & 121.54(12) \\ \mathrm{N}(2)-\mathrm{C}(8)-\mathrm{C}(9) & 116.40(12) \\ \mathrm{C}(10)-\mathrm{C}(9)-\mathrm{C}(14) & 118.74(13) \\ \mathrm{C}(10)-\mathrm{C}(9)-\mathrm{C}(8) & 123.81(12) \\ \mathrm{C}(14)-\mathrm{C}(9)-\mathrm{C}(8) & 117.43(12) \\ \mathrm{C}(11)-\mathrm{C}(10)-\mathrm{C}(9) & 120.46(12) \\ \mathrm{C}(10)-\mathrm{C}(11)-\mathrm{C}(12) & 120.35(14) \\ \mathrm{C}(13)-\mathrm{C}(12)-\mathrm{C}(11) & 119.40(14) \\ \mathrm{C}(12)-\mathrm{C}(13)-\mathrm{C}(14) & 120.49(13) \\ \mathrm{C}(13)-\mathrm{C}(14)-\mathrm{C}(9) & 120.51(14)\end{array}$

Table 4. Anisotropic displacement parameters $\left(\AA^{2} \times 10^{3}\right)$ for $\mathbf{4 1 b}$. The anisotropic displacement factor exponent takes the form: $-2 \pi^{2}\left[h^{2} a^{* 2} U^{11}+\ldots+2 h k a^{*} b^{*} U^{12}\right]$

\begin{tabular}{lcccccc}
\hline & $\mathrm{U}^{11}$ & $\mathrm{U}^{22}$ & $\mathrm{U}^{33}$ & $\mathrm{U}^{23}$ & $\mathrm{U}^{13}$ & $\mathrm{U} 12$ \\
\hline $\mathrm{O}(1)$ & $28(1)$ & $33(1)$ & $28(1)$ & $-9(1)$ & $4(1)$ & $-4(1)$ \\
$\mathrm{O}(2)$ & $42(1)$ & $47(1)$ & $29(1)$ & $8(1)$ & $-3(1)$ & $13(1)$ \\
$\mathrm{N}(1)$ & $25(1)$ & $30(1)$ & $22(1)$ & $-3(1)$ & $1(1)$ & $4(1)$ \\
$\mathrm{N}(2)$ & $23(1)$ & $33(1)$ & $21(1)$ & $3(1)$ & $0(1)$ & $3(1)$ \\
$\mathrm{C}(1)$ & $29(1)$ & $27(1)$ & $28(1)$ & $-7(1)$ & $-4(1)$ & $7(1)$ \\
$\mathrm{C}(2)$ & $36(1)$ & $43(1)$ & $28(1)$ & $-13(1)$ & $-8(1)$ & $11(1)$ \\
$\mathrm{C}(3)$ & $41(1)$ & $46(1)$ & $24(1)$ & $-4(1)$ & $-3(1)$ & $18(1)$ \\
$\mathrm{C}(4)$ & $40(1)$ & $40(1)$ & $23(1)$ & $1(1)$ & $3(1)$ & $5(1)$ \\
$\mathrm{C}(5)$ & $19(1)$ & $30(1)$ & $22(1)$ & $-3(1)$ & $-2(1)$ & $4(1)$ \\
$\mathrm{C}(6)$ & $24(1)$ & $30(1)$ & $23(1)$ & $0(1)$ & $-1(1)$ & $4(1)$ \\
$\mathrm{C}(7)$ & $35(1)$ & $28(1)$ & $31(1)$ & $-4(1)$ & $-2(1)$ & $-2(1)$ \\
$\mathrm{C}(8)$ & $25(1)$ & $29(1)$ & $24(1)$ & $3(1)$ & $-4(1)$ & $-5(1)$ \\
$\mathrm{C}(9)$ & $24(1)$ & $29(1)$ & $21(1)$ & $3(1)$ & $-3(1)$ & $-8(1)$ \\
$\mathrm{C}(10)$ & $29(1)$ & $28(1)$ & $20(1)$ & $4(1)$ & $-1(1)$ & $-6(1)$ \\
$\mathrm{C}(11)$ & $31(1)$ & $30(1)$ & $26(1)$ & $4(1)$ & $-1(1)$ & $-4(1)$ \\
$\mathrm{C}(12)$ & $32(1)$ & $39(1)$ & $23(1)$ & $-1(1)$ & $2(1)$ & $-6(1)$ \\
$\mathrm{C}(13)$ & $36(1)$ & $49(1)$ & $20(1)$ & $8(1)$ & $-2(1)$ & $-6(1)$
\end{tabular}


Table 5. Hydrogen coordinates ( $\left.\mathrm{x} 10^{4}\right)$ and isotropic displacement parameters $\left(\AA^{2} \mathrm{x} 10\right.$ 3) for $\mathbf{4 1 b}$.

\begin{tabular}{lrrrr}
\hline & $\mathrm{x}$ & $\mathrm{y}$ & $\mathrm{z}$ & $\mathrm{U}(\mathrm{eq})$ \\
\hline $\mathrm{H}(1)$ & $1570(16)$ & $1566(16)$ & $-1223(12)$ & $26(4)$ \\
$\mathrm{H}(2)$ & $-672(19)$ & $3956(18)$ & $1440(14)$ & $31(4)$ \\
$\mathrm{H}(2 \mathrm{~A})$ & $20(20)$ & $1710(20)$ & $-2642(17)$ & $56(6)$ \\
$\mathrm{H}(2 \mathrm{~B})$ & $-800(20)$ & $2817(17)$ & $-2122(15)$ & $36(4)$ \\
$\mathrm{H}(3 \mathrm{~A})$ & $1750(20)$ & $2958(16)$ & $-3311(14)$ & $34(4)$ \\
$\mathrm{H}(3 \mathrm{~B})$ & $520(20)$ & $3930(18)$ & $-3285(16)$ & $43(5)$ \\
$\mathrm{H}(4 \mathrm{~A})$ & $1523(17)$ & $5053(17)$ & $-1897(13)$ & $28(4)$ \\
$\mathrm{H}(4 \mathrm{~B})$ & $2900(20)$ & $4216(19)$ & $-2119(17)$ & $50(6)$ \\
$\mathrm{H}(6)$ & $1515(19)$ & $2334(16)$ & $1013(14)$ & $33(4)$ \\
$\mathrm{H}(7 \mathrm{~A})$ & $-961(19)$ & $2475(16)$ & $-277(13)$ & $30(4)$ \\
$\mathrm{H}(7 \mathrm{~B})$ & $-100(20)$ & $1200(20)$ & $83(17)$ & $55(6)$ \\
$\mathrm{H}(10)$ & $-1894(19)$ & $4843(17)$ & $2475(14)$ & $32(4)$ \\
$\mathrm{H}(11)$ & $-3380(20)$ & $5603(19)$ & $3831(17)$ & $48(5)$ \\
$\mathrm{H}(12)$ & $-3364(19)$ & $4659(15)$ & $5533(15)$ & $32(4)$ \\
$\mathrm{H}(13)$ & $-1790(20)$ & $3088(19)$ & $5935(17)$ & $52(5)$ \\
$\mathrm{H}(14)$ & $-240(20)$ & $2255(17)$ & $4611(14)$ & $37(5)$ \\
& & & & \\
\hline
\end{tabular}

Table 6. Torsion angles $\left[{ }^{\circ}\right]$ for $\mathbf{4 1 b}$.

$\mathrm{C}(5)-\mathrm{N}(1)-\mathrm{C}(1)-\mathrm{C}(2)$
$\mathrm{C}(4)-\mathrm{N}(1)-\mathrm{C}(1)-\mathrm{C}(2)$
$\mathrm{C}(5)-\mathrm{N}(1)-\mathrm{C}(1)-\mathrm{C}(7)$
$\mathrm{C}(4)-\mathrm{N}(1)-\mathrm{C}(1)-\mathrm{C}(7)$
$\mathrm{N}(1)-\mathrm{C}(1)-\mathrm{C}(2)-\mathrm{C}(3)$
$\mathrm{C}(7)-\mathrm{C}(1)-\mathrm{C}(2)-\mathrm{C}(3)$
$\mathrm{C}(1)-\mathrm{C}(2)-\mathrm{C}(3)-\mathrm{C}(4)$
$\mathrm{C}(5)-\mathrm{N}(1)-\mathrm{C}(4)-\mathrm{C}(3)$

$136.18(12)$

$-26.21(15)$

$12.02(15)$

$-150.37(12)$

31.26(13)

143.43(13)

$-26.78(15)$

$-149.73(13)$ 


$\begin{array}{lc}\mathrm{C}(1)-\mathrm{N}(1)-\mathrm{C}(4)-\mathrm{C}(3) & 9.69(15) \\ \mathrm{C}(2)-\mathrm{C}(3)-\mathrm{C}(4)-\mathrm{N}(1) & 11.15(15) \\ \mathrm{C}(4)-\mathrm{N}(1)-\mathrm{C}(5)-\mathrm{O}(1) & -13.3(2) \\ \mathrm{C}(1)-\mathrm{N}(1)-\mathrm{C}(5)-\mathrm{O}(1) & -172.51(12) \\ \mathrm{C}(4)-\mathrm{N}(1)-\mathrm{C}(5)-\mathrm{C}(6) & 167.16(13) \\ \mathrm{C}(1)-\mathrm{N}(1)-\mathrm{C}(5)-\mathrm{C}(6) & 8.00(14) \\ \mathrm{C}(8)-\mathrm{N}(2)-\mathrm{C}(6)-\mathrm{C}(5) & -131.31(13) \\ \mathrm{C}(8)-\mathrm{N}(2)-\mathrm{C}(6)-\mathrm{C}(7) & 112.23(15) \\ \mathrm{O}(1)-\mathrm{C}(5)-\mathrm{C}(6)-\mathrm{N}(2) & 32.33(18) \\ \mathrm{N}(1)-\mathrm{C}(5)-\mathrm{C}(6)-\mathrm{N}(2) & -148.18(11) \\ \mathrm{O}(1)-\mathrm{C}(5)-\mathrm{C}(6)-\mathrm{C}(7) & 156.12(14) \\ \mathrm{N}(1)-\mathrm{C}(5)-\mathrm{C}(6)-\mathrm{C}(7) & -24.38(13) \\ \mathrm{N}(1)-\mathrm{C}(1)-\mathrm{C}(7)-\mathrm{C}(6) & -26.29(14) \\ \mathrm{C}(2)-\mathrm{C}(1)-\mathrm{C}(7)-\mathrm{C}(6) & -138.22(13) \\ \mathrm{N}(2)-\mathrm{C}(6)-\mathrm{C}(7)-\mathrm{C}(1) & 152.62(11) \\ \mathrm{C}(5)-\mathrm{C}(6)-\mathrm{C}(7)-\mathrm{C}(1) & 30.71(13) \\ \mathrm{C}(6)-\mathrm{N}(2)-\mathrm{C}(8)-\mathrm{O}(2) & 1.0(2) \\ \mathrm{C}(6)-\mathrm{N}(2)-\mathrm{C}(8)-\mathrm{C}(9) & -178.21(11) \\ \mathrm{O}(2)-\mathrm{C}(8)-\mathrm{C}(9)-\mathrm{C}(10) & 175.93(14) \\ \mathrm{N}(2)-\mathrm{C}(8)-\mathrm{C}(9)-\mathrm{C}(10) & -4.86(19) \\ \mathrm{O}(2)-\mathrm{C}(8)-\mathrm{C}(9)-\mathrm{C}(14) & -5.48(19) \\ \mathrm{N}(2)-\mathrm{C}(8)-\mathrm{C}(9)-\mathrm{C}(14) & 173.73(13) \\ \mathrm{C}(14)-\mathrm{C}(9)-\mathrm{C}(10)-\mathrm{C}(11) & -0.1(2) \\ \mathrm{C}(8)-\mathrm{C}(9)-\mathrm{C}(10)-\mathrm{C}(11) & 178.49(13) \\ \mathrm{C}(9)-\mathrm{C}(10)-\mathrm{C}(11)-\mathrm{C}(12) & -1.5(2) \\ \mathrm{C}(10)-\mathrm{C}(11)-\mathrm{C}(12)-\mathrm{C}(13) & 1.5(2) \\ \mathrm{C}(11)-\mathrm{C}(12)-\mathrm{C}(13)-\mathrm{C}(14) & 0.1(2) \\ \mathrm{C}(12)-\mathrm{C}(13)-\mathrm{C}(14)-\mathrm{C}(9) & -1.6(2) \\ \mathrm{C}(10)-\mathrm{C}(9)-\mathrm{C}(14)-\mathrm{C}(13) & 1.6(2) \\ \mathrm{C}(8)-\mathrm{C}(9)-\mathrm{C}(14)-\mathrm{C}(13) & -177.05(13) \\ & \end{array}$

\section{References}

1. SMART Software Users Guide, Version 5.1, Bruker Analytical X-Ray Systems, Inc.; Madison, WI 1999. 
2. SAINT Software Users Guide, Version 6.0, Bruker Analytical X-Ray Systems, Inc.; Madison, WI 1999.

3. Sheldrick, G. M. SADABS, Version 2.10, Bruker Analytical X-Ray Systems, Inc.; Madison, WI 2002.

4. Sheldrick, G. M. SHELXTL Version 6.12, Bruker Analytical X-Ray Systems, Inc.; Madison, WI 2001.

5. International Tables for X-Ray Crystallography 1992, Vol. C., Dordrecht: Kluwer Academic Publishers.

6. Flack, H. D. Acta. Cryst., A39, 876-881, 1983.

\section{Definitions}

$\mathrm{wR} 2=\left[\left[\mathrm{w}\left(\mathrm{F}_{\mathrm{o}}^{2}-\mathrm{F}_{\mathrm{c}}^{2}\right)^{2}\right] /\left[\mathrm{w}\left(\mathrm{F}_{\mathrm{o}}^{2}\right)^{2}\right]\right]^{1 / 2}$

$\mathrm{R} 1=|| \mathrm{F}_{\mathrm{o}}|-| \mathrm{F}_{\mathrm{c}}|/| \mathrm{F}_{\mathrm{o}} \mid$

Goof $=\mathrm{S}=\left[\left[\mathrm{w}\left(\mathrm{F}_{\mathrm{o}}^{2}-\mathrm{F}_{\mathrm{c}}^{2}\right)^{2}\right] /(\mathrm{n}-\mathrm{p})\right]^{1 / 2}$ where $\mathrm{n}$ is the number of reflections and $\mathrm{p}$ is the total number of parameters refined.

The thermal ellipsoid plot is shown at the $50 \%$ probability level. 